An anatomy of colonial states and fiscal regimes in Portuguese Africa:

Long-term transformations in Angola and Mozambique, 1850s-1970s

Kleoniki Alexopoulou 


\section{Thesis committee}

\section{Promotors}

Prof. Dr E.H.P. Frankema

Professor of Rural and Environmental History

Wageningen University \& Research

Prof. Dr E.J.V. van Nederveen Meerkerk

Associate Professor, Department of Economic and Social History

Utrecht University

Special Professor of Comparative History of Households, Gender and Work

Radboud University Nijmegen

\section{Co-promotor}

Dr. J.M.H.M. Santos

Assistant Professor, Centro de Estudos Africanos

University of Porto, Portugal

\section{Other members}

Dr L.A. Gardner, London School of Economics, United Kingdom

Prof. Dr A.C. Pinto, University of Lisbon, Portugal

Dr F.R. da Silva, International Institute of Social History, Amsterdam

Prof. Dr J.W.M. van Dijk, Wageningen University \& Research 


\title{
An anatomy of colonial states and fiscal regimes in Portuguese Africa: \\ Long-term transformations in Angola and Mozambique, 1850s-1970s
}

Kleoniki Alexopoulou

\author{
Thesis \\ submitted in fulfilment of the requirements for the degree of doctor \\ at Wageningen University \\ by the authority of the Rector Magnificus, \\ Prof. Dr A.P.J. Mol, \\ in the presence of the \\ Thesis Committee appointed by the Academic Board \\ to be defended in public \\ on Tuesday 4 December 2018 \\ at 1:30 p.m. in the Aula.
}


Kleoniki Alexopoulou

An anatomy of colonial states and fiscal regimes in Portuguese Africa: Long-term transformations in Angola and Mozambique, 1850s-1970s, 220 pages.

$\mathrm{PhD}$ thesis, Wageningen University, Wageningen, the Netherlands (2018)

With references, with summary in English

ISBN: 978-94-6343-374-7

DOI: https://doi.org/10.18174/463804 


\section{Personal note}

During my previous studies, I was often attracted by popular historical books sold at the central bookstores of the city, at the airport or at the train stations. What struck me the most while I was browsing through such books was the absence of the seemingly simple but so crucial question of "who is paying?". Either the books were telling the story of a political regime or a national army or they dealt with the history of technology and infrastructure, very few authors brought up the question of who is paying for all this. Who is paying for the war, for the king, for the railway? And who is producing the wealth that is accumulated and (re-) invested in war making and road construction? In a way, who "embodies" the resources and the capital (financial, material and human)?

History is the best "natural experiment" an economist, a sociologist or a political scientist can "make". However, the laboratory of history resembles a black box that can keep giving different answers if one keeps opening it from different angles. The question determines to a large extent the answer. The perspective, from which a story is told, determines to a large extent the perception of the story. This $\mathrm{PhD}$ gave me the opportunity to tell the story of how states and fiscal regimes evolved in Portuguese Africa, from the early colonial era to the late colonial years before independence, paying attention to who made the decisions, who produced wealth and who paid taxes.

\section{Acknowledgements}

I owe deep gratitude...

...To my father Dimitris, who inspired curiosity in me, taught me humanism and rationality in matters of both society and nature. Plus, he filled in several excel files and edited maps, when deadlines approached. To my mother Naja, who protected me whenever I was ill and encouraged me to set goals and be proud of who I am.

To my partner $\Phi \alpha i \delta \omega v$, who threw light on the darkness of the past, "transmitted" to me enthusiasm about the world and despite moments of unrest, opened my heart to happiness.

To my sister Evina, who showed to me compassion and sensitivity. To my grandmother Evgenia, who taught me perfectionism (though I naturally resist). To my uncle Giannis in 
Switzerland who taught me how to whistle when I was little, which helped me stay calm since then.

To the ones who left $\kappa \alpha 1 \delta \varepsilon v \pi \rho o ́ \lambda \alpha \beta \alpha v$. To Frida who taught me to unlock the mystery of my dreams and appreciate the value of music and art, apart from books. To Giorgos and my grandfather Aggelos who showed to me how to overcome obstacles and insist till the end.

To my promotor Ewout Frankema and co-promotor Elise van Nederveen Meerkerk, who were the best supervisors I ever had. For the "tons of knowledge", creative ideas, empirical methods and systematic feedback. You are a cornerstone in my academic life, which hopefully will continue further along.

To my research group RHI: Special thanks to Sandra and Carry who have been always willing to make life easier for me and protect me from bureaucracy; To Dacil Juif, who has been a valuable co-author and good friend; To Kate and Corinne for the continuous psychological and intellectual support, to Angus for the unbearable amount of British humour and "f" words, to Michiel for the intriguing questions, to Harm for the mid-day breaks and car rides, to Anton for the kindness, to Pim and Danielle for the tips, and to the rest of the group members for the inspiring conversations not only at the office but also during our conference trips.

To my far-away supervisors and colleagues Prof. Maciel Santos, Dr. Corrado Tornimbeni, Dr. Leigh Gardner, Prof. Nuno Valério, Dr. Filipa Ribeiro, Prof. António Costa Pinto and Dr. Barbara Direito, who helped me formulating my research objectives as well as digging into the archives and libraries of Portugal, Mozambique, South Africa, Britain and Italy. To Diogo Paiva, who assisted me with the collection of early data and without him the time span of my thesis would be much shorter.

To African Economic History Network, Hellenic Network for African Studies and Lusophone African Studies Organization for disseminating my work.

To my teachers and classmates at Panteion University and University of Athens, who built the theoretical foundations of my critical thinking in social sciences. Special thanks to Prof Nikos Theotokas and Dr Stavros Konstantakopoulos. The latter accepted to supervise my Bachelor's thesis on political elites in post-colonial Africa twelve years ago, when nobody else at the University was willing to dive into such a "distant" subject. Unfortunately he passed away a few years ago, but his memory is kept alive. 
To Roelien for teaching me Portuguese and to my tango and yoga teachers, who helped me keep balance during difficult times.

To the activist group Reinform, which offered me political shelter. Particularly, I would like to thank my beloved housemate in Amsterdam Antonia, who was my window to the outside world during the days (and nights) of writing; Ioanna, who besides her friendship offered me her editing skills; and Athina, who was my first generous host in Amsterdam. Dimitris, Stella, Christina and Nikolas I love being member of your family. Vicky, we did not find time to make that GIS map but I am grateful for your willingness to help me. Nikoleta, I appreciate your efforts to teach me how to bike and facilitate my integration into the Dutch society, though I admit I still don't use it in my everyday life (no-one is perfect).

To the dream neighbourhood (бvvorkía to óveıрo) of Nikos, Paris, Nasia, Ismini, Kostas and Alex for dancing, drinking and cooking together whenever possible. To Xrats, Pericles, Vasilis, Kostas, Marios, Cid, Dimitris, Marianna and the other members of the music band Aman Mollie that I always wanted to sing for and finally discovered over the last year.

To Peni, Kostas and my other warm friends in Utrecht, who accommodated me after fests; to my former housemates and cat-loving neighbours Arron, Zanin, and Aggelos who took care of Zarathustra whenever I was travelling around. Eleni, Stavroula and Sofia, we lost each other throughout the years, but our good moments stay untouched.

To my lifelong friends Anna-Maria, Myrto and Ioanna for their constant "presence" and care all the way from London, Athens and Paris. To my beloved relatives in Patras and Lefkada and particularly my cousin Naussika.

Last but not least, to the digital magazine Marginalia which re-introduced me to the magical world of collective initiatives and exchange of ideas in my country of origin, Greece.

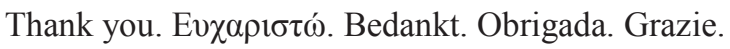




\section{CONTENTS}

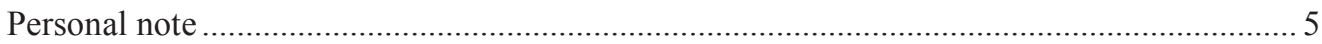

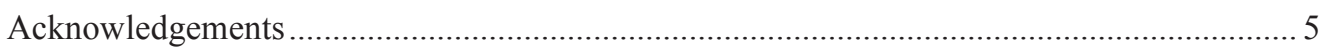

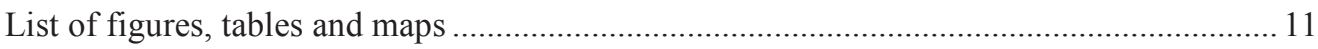

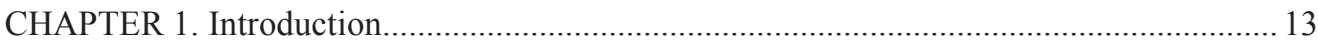

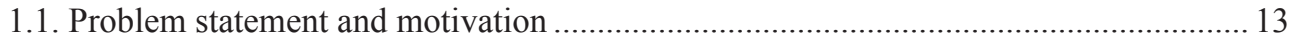

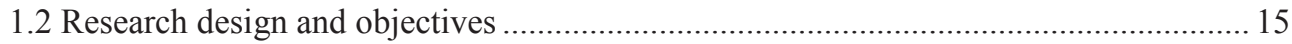

1.3. Fiscal regimes as causes and outcomes of state and social (trans)formations............... 16

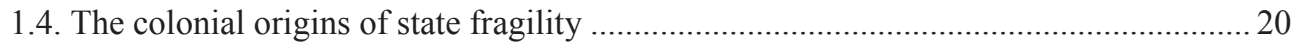

1.5. Extractive and developmental fiscal states. The case of Portuguese Africa ................. 22

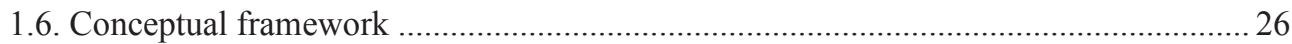

1.7. Methodology and sources: limitations and possibilities .............................................. 33

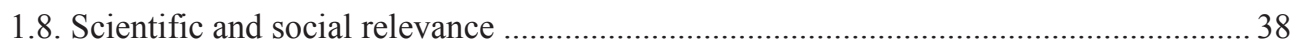

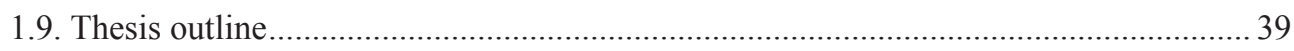

CHAPTER 2. Local Conditions and Metropolitan Visions. Fiscal Policies and Practices in

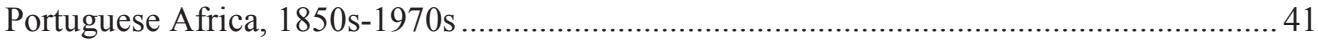

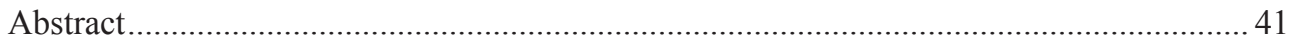

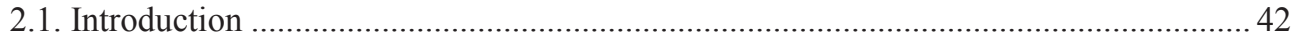

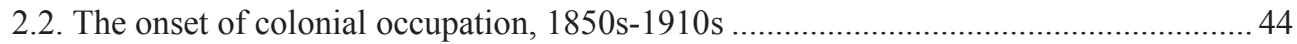

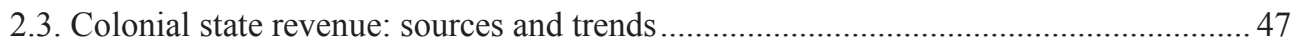

2.4. Regime changes in Portugal and the dogma of fiscal balance ..................................... 57

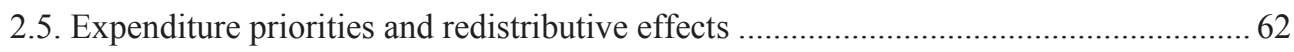

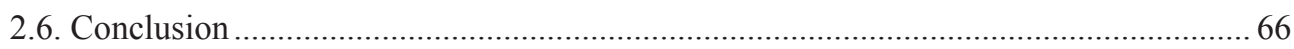

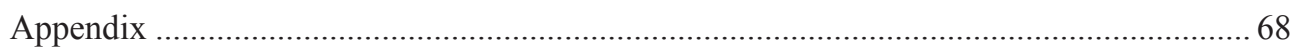

CHAPTER 3. Colonial State Formation Without Integration: Tax Capacity and Labour Regimes in Portuguese Mozambique, 1890s-1970s.............................................................. 73

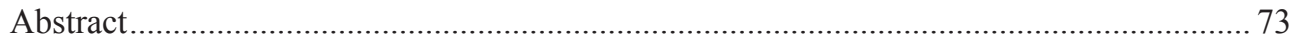

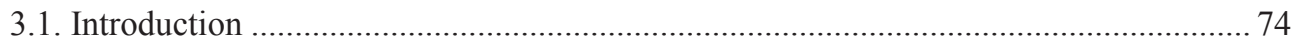

3.2. Fiscal capacity-building in colonial Africa and Mozambique..................................... 77

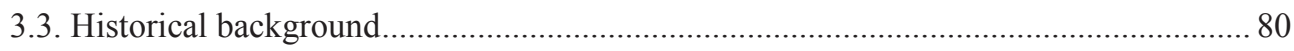

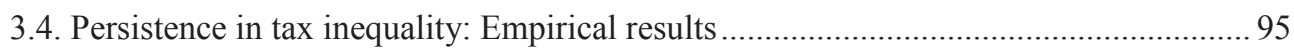

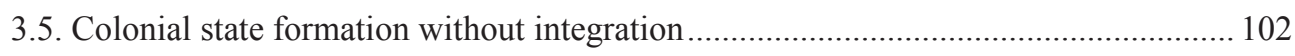

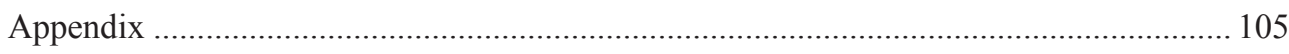


CHAPTER 4. Imperialism of Jackals and Lions. The Militarization of Portuguese Africa in

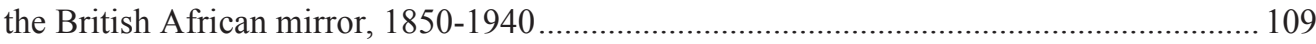

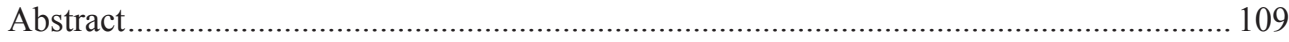

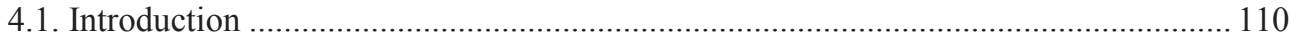

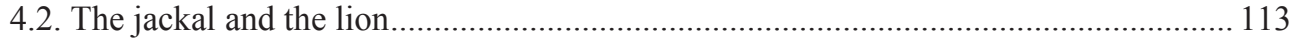

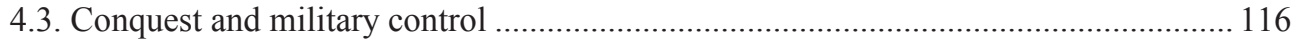

4.4. Military expenditure in Angola and Mozambique ................................................... 120

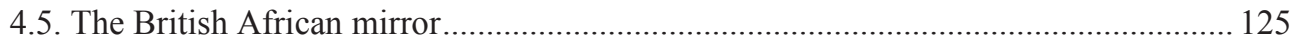

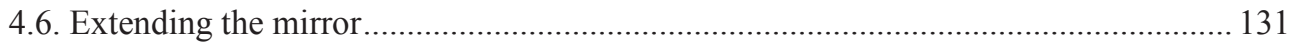

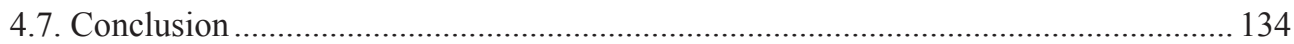

CHAPTER 5. 'Development' through Coercion. Railway geographies and infrastructural

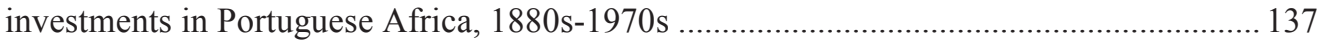

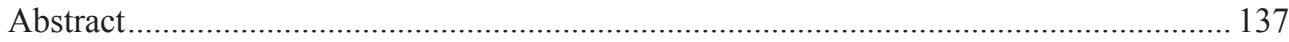

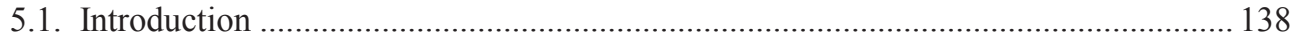

5.2. Varying perspectives on railways in colonial Africa................................................. 143

5.3. Railway construction and operation: Priorities of private capital and colonial states. 145

5.4. Railways, urbanization and colonial settlement ........................................................ 162

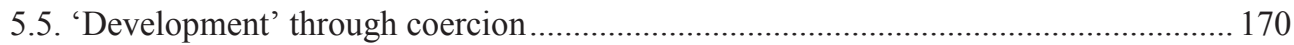

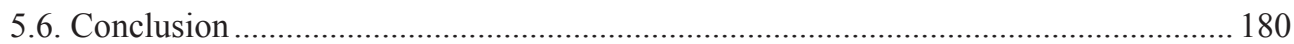

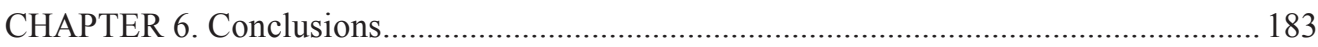

6.1. Portuguese Africa: an exceptional case of extractive minimalism............................. 184

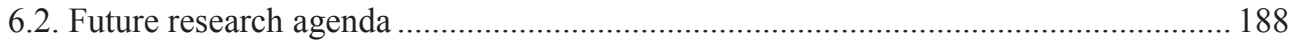

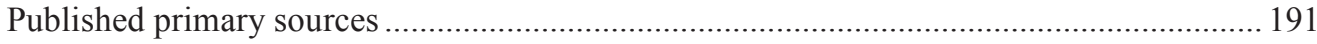

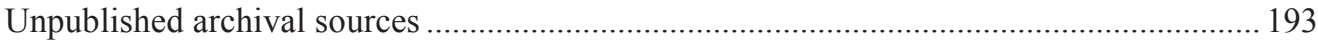

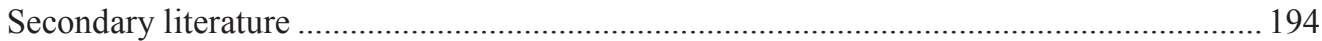

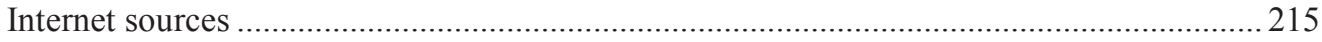




\section{List of figures, tables and maps}

Figure 1.1: Conceptual model of the drivers of institutional strength and weakness for the metropolitan and colonial states in Africa.......................................................................... 31

Figure 2.1: Real tax and non-tax revenue in Mozambique, 1850s-1970s ............................. 49

Figure 2.2: Real tax and non-tax revenue in Angola, 1850s-1970s ...................................... 50

Figure 2.3: Import and export taxes, Mozambique 1930s-1970s.......................................... 51

Figure 2.4: Import and export taxes, Angola 1930s-1970s ................................................... 51

Figure 2.5: Real direct tax revenue per capita and per zone in Mozambique, 1930s-1970s... 56

Figure 2.6: Shares of debt service in total expenditure of Angola and Mozambique, 1920s-

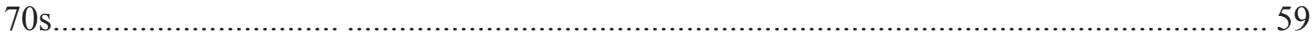

Figure 2.7: Shares of public ordinary expenditure in Mozambique, 1930s-1970s ................ 63

Figure 2.8: Shares of public ordinary expenditure, Angola 1930s-1970s............................. 64

Figure 3.1. Number of migrants from Mozambique to South Africa and Rhodesia, 1902-

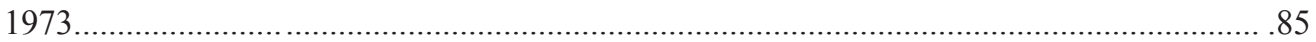

Figure 3.2: Migrants from southern districts to Transvaal (South Africa), 1929-1951 .......... 88

Figure 3.3: Production of raw cotton by indigenes per district in Mozambique, 1939-1962 . 94

Figure 3.4: Total state revenue and direct tax revenue in Mozambique, 1941-1973 ............. 96

Figure 3.5: Real direct tax revenue per capita by zone in Mozambique, 1930-1973 ............. 97

Figure 4.1: Share of security spending in total expenditure, Angola and Mozambique, 18501940.

Figure 4.2: Real per capita expenditure on security forces, Angola and Mozambique, 18501940 (in 1914 Escudos).

Figure 4.3: Metropolitan transfers to the colonies in Portuguese government expenditure,

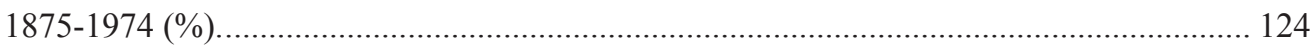

Figure 5.1. Railway track development in Angola and Mozambique, 1889-1973 .............. 140

Figure 5.2: Shares of railway and road passengers per district in Mozambique, 1926-1970 163

Figure 5.3: Shares of commodities transported per district in Mozambique, 1926-1970 .... 163

Figure 5.4: Distribution of indigenous and non-indigenous population over districts (as share

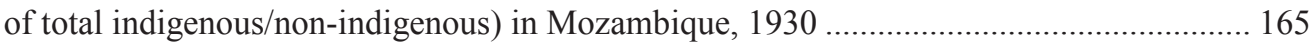

Figure 5.5: Shares of railway and road passengers per district in Angola, 1932-1970......... 166

Figure 5.6: Shares of commodities transported per district in Angola, 1932-1970 .............. 167

Figure 5.7: Distribution of indigenous and non-indigenous population over districts (as share of total indigenous/non-indigenous) in Angola, 1933 168 
Figure 5.8: Real revenue from direct taxes in Mozambique, 1865-1958 ............................. 175

Figure 5.9: Shares of public expenditure by category in Mozambique, 1930-1973 ............. 177

Figure 5.10: Real revenue from direct taxes in Angola, 1889-1963 …................................ 178

Figure 5.11: Shares of public ordinary expenditure by category in Angola, 1932-1972 ...... 179

Table 1.1: Transformations of the fiscal states of Portuguese Angola and Mozambique, 1850s$1960 \mathrm{~s}$

Table 2.1: Direct tax revenue in Mozambique, 1920-1960 53

Table 4.1: Shares of public spending on military and marine forces, 1865-1939. 128

Table 4.2: Public spending on military forces per capita (in British pounds), 1898-1939 ... 129

Table 4.3: Size of permanent colonial armed forces in colonial Africa, 1910 and 1930 129

Table 4.4: Expenditure on health and education as a share of total government expenditure in Portuguese and British Africa, 1920-1940

Table 5.1: Comparative size for railway network in Portuguese Africa and surrounding colonies, 1960 .

Table 5.2: Railway lines principally constructed by private capital

Table 5.3: Railway lines principally operated by the colonial states of Angola and Mozambique. 158

Map 3.1: Districts of Mozambique, 1963 82

Map 4.1: The pink map (Mapa cor-de-rosa), 1884-85

Map 5.1: Railway lines in civil-war Mozambique 141

Map 5.2: Map of railway lines and mineral deposits in colonial Angola 142

Map 5.3: The Benguela Railway..... 149

Image 5.1: The end of the railway at Zambezi river in Mozambique, 1931 153 


\section{Chapter 1. Introduction}

\subsection{Problem statement and motivation}

Accounting for the great variation in long-term processes of state formation is an important part of the work conducted by historians, political scientists and economists, and requires interdisciplinary approaches and multi-disciplinary perspectives. This thesis focuses on the relationship between state formation and fiscal development - including both taxation and public spending patterns - in two former Portuguese colonies in Africa, Angola and Mozambique. Fiscal capacity and state development are tightly interconnected. Tax revenues are required to pay for basic government services, such as administration, security and law enforcement, while the ability to raise taxes and allocate public revenue depends on the capacity of a state to wield power and legitimize its rule.

State failure has been a particular - albeit no exclusive - characteristic of many African societies in the post-colonial era, and a great deal of these societies are still struggling with the effective organization of basic state services, such as the imposition of an embracing tax system and the establishment of a violence monopoly. Angola and Mozambique have witnessed an especially dramatic road towards independence and long-lasting civil wars before conditions emerged in which postcolonial governments were in a position to uphold a rudimentary system of rule of law and invest in basic public services. This legacy of state fragility, which even in an African comparative perspective was particularly violent, raises a number of questions about the connection between fiscal capacity and state capacity during the colonial era.

Incipient colonial states in Africa confronted a huge challenge and this was no less the case for Portuguese Africa: most of the central revenue collection mechanisms had to be set up from scratch. This confronted colonial governments, indigenous ${ }^{1}$ communities and

\footnotetext{
${ }^{1}$ Note on terminology: As Maravall Buckwalter (2017) states in her dissertation about Algeria, there is no settled consensus on the correct terminology used to refer to local population in Africa prior to colonialism. The Portuguese colonial sources that I have used in this thesis classify the population groups into "indígena", "mista/mestiça" and "não indígena". Both the Portuguese and the English terminology (natives/indigenous and of mixed race) are quite fraught as they replicate colonial vocabulary. Additionally, the terms "Mozambican" or "Angolan" may cause confusion, because many settlers called themselves "Mozambicans" or "Angolans" after decades of settlement. Alternatively, I could categorize the groups in "Mozambicans/Angolans" on the one hand, and "Portuguese Mozambicans/Angolans," on the other hand. However, in this thesis that largely consists of comparative analysis, this terminology
} 
European settlers with a need to impose, adapt or resist major reforms in social organization. To begin with, how would colonial states monitor new tax legislation and ensure that indigenous Africans would comply? In the absence of legitimacy, coercion played a significant role in colonial tax enforcement, but even this was not easy to organize or finance. Many colonial governments, especially in British Africa, used a system of indirect rule, by delegating tax collection and labour recruitment to local rulers (tribal chiefs), before siphoning revenues off to the centre, but what to do in case local chiefs or leaders would resist to cooperate? For Portugal, as a metropolitan state, these issues were probably more pronounced than for instance for Britain, because the military and industrial means of Portugal were far less developed than those of Britain.

But in the new wave of studies of colonial fiscal development in Africa that has emerged during the last decade (Mkandawire 2010, Frankema 2010, Frankema 2011, Gardner 2012, Huillery 2014, Frankema and van Waijenburg 2014, Andersson 2017, Gwaindepi 2018, van Waijenburg 2018, Cogneau et.al 2018) the focus has largely been on British and French Africa, with a few studies on the Belgian Congo (Gardner 2013, Frankema and Buelens 2014, de Roo 2017). However, Portuguese Africa has remained understudied to a very large extent. It thus remains unclear how the two main Portuguese colonies of Mozambique and Angola compare to British and French Africa in terms of fiscal development. To what extent were they representative for general patterns of colonial state formation, and to what extent were they exceptional cases?

Few scholars have studied the Portuguese tax system in Africa. Havik considers taxation to be a critical component of the so-called "trilogy of colonial extraction" including labour and natural resources (2013, p.161). This thesis builds on Havik's analysis, by elaborating certain dimensions of fiscalization and exploring additional ones. For instance, Havik emphasizes the significance of native taxation ${ }^{2}$ for the sovereignty of the colonial state. This thesis provides ample empirical evidence confirming his argument that direct taxation grew out of the need to fund military campaigns (1890-1918) and sovereignty mechanisms in Portuguese Africa, as it also occurred in early modern Europe.

would be ambiguous. Therefore, I will mainly use the term "indigenous/native" when referring to the populations already located in Mozambique and Angola prior to Portuguese settlement. Nevertheless, when the context is sufficiently clear, I will consider the term "Africans" as a proxy for indigenous people. Concerning the non-indigenous people, I will indistinctly use the terms "Europeans" or "white settlers".

${ }^{2}$ Native or indigenous taxation refers to taxes paid by the native/indigenous population in colonial Africa. 
On the other hand, this thesis differentiates from Havik's work (2013) in several aspects. First, I use a periodization scheme different from Havik's classification of colonial revenue cycles (ibid, pp.172-173), as my analysis extends further back into the mid-19 ${ }^{\text {th }}$ century. More importantly, Havik (2013) as well as Havik, Keese and Santos (2015) principally investigate the revenue side of Portuguese fiscal systems, while this thesis equally integrates public spending into the analysis. Therefore, it is not only the study's time span that differs but also the criteria, according to which fiscal regimes are classified as extractive, minimalist or developmental. Last, previous literature either focusses on certain case-studies or on cross-colony comparisons. In contrast, in this thesis I attempt to reveal cross-imperial commonalities and/or exceptionalities, by comparing Portuguese Mozambique and Angola with British and French African colonies.

\subsection{Research design and objectives}

The research design of this thesis is based on the development of three analytical perspectives, each of which is associated with a distinct historical debate. These three perspectives are: 1) The development of the fiscal system over the span of roughly one century, from the occupation of the first parts of territory in the coastal hinterlands during the $1850 \mathrm{~s}$, to the era of independence granted after a long war in both colonies in the 1970s. 2) The comparison of taxation patterns, as well as government investment policies and practices (e.g. in the security apparatus and railway infrastructure) between Angola and Mozambique. This comparison is especially useful to study the effects of metropolitan identity and local African conditions on the design of colonial fiscal systems. 3) The comparison of specific features of the fiscal system in Portuguese Africa, that is Angola and Mozambique combined, with the fiscal systems that emerged in other African colonies, including British, French and Belgian dependencies.

Each of these three perspectives raises a specific set of research questions. First, regarding the long-term development of fiscal systems, the key question is how a comparatively weak metropolitan state solved the catch-22 of effective occupation and revenue raising? The conquest and consolidation of territories required vast investments in military capacity, but these investments could only be paid from local revenue sources after indigenous Africans were integrated in colonial tax systems. This challenge also raises questions regarding the preference for heavy coercion and repression over long-term efforts to build consensus and enhance the legitimacy of colonial rule. This thesis explores how the Portuguese dealt with these challenges, 
how their views changed over time, and how the metropole related to the colonial territories in terms of trade relations, financial transfers (loans and subsidies) and administrative organization.

Second, the cross-colony comparison between Angola and Mozambique raises issues regarding the development of revenue and expenditure patterns. What were the main differences in the sources of revenue? Why did the Mozambican government rely more on direct taxes, especially native taxes, than the state of Angola? Why did fiscal unification prove to be more difficult to establish in Mozambique than in Angola? And what difference did historical paths of settlement and pre-colonial state formation make for the evolution of central fiscal administrations during the colonial era? Since both colonies were ruled by the same metropole, the cross-colony comparisons will shed light on the impact of local conditions on the development of the state, as opposed to effects that different types of metropolitan governance had.

The distinctive features of Portuguese rule will then be isolated by situating both Angola and Mozambique in the broader context of colonial rule in Africa. The comparison will again focus on questions regarding the per capita amount of revenue that is raised, the observed expenditure priorities in absolute and relative terms and the changing foci of colonial investment programs. In this comparative perspective Portuguese rule will also be explored in relation to the extensive use of forced labour, the heavy investments in military capacity and its approach to infrastructural investments. In view of these questions, understanding the paradox of a weak metropole and a strongly repressive colonial state will be one of the key objectives. This paradox of the weak-strong state will be further elaborated in section 1.6 as part of my conceptual framework. In sections 1.3 to 1.5 I will first pay attention to the various strands of literature that are connected with these research objectives.

\subsection{Fiscal regimes as causes and outcomes of state and social (trans)formations}

Les finances soin les nerfs de la République.

Jean Bodin (1993[1583]). ${ }^{3}$

Levi has stated that "the history of state revenue production is the history of the evolution of the state" (1988, p.1). Tax revenues formalize the obligations of individuals to society,

\footnotetext{
${ }^{3}$ Les Six Livres de la République, Livre Sixiéme, Chapitre II.
} 
presuppose legitimacy and set the limits of governments' powers, redistribute wealth and allocate income, make investments in collective goods possible, develop bureaucratic administration and property rights institutions, secure law and order, and prevent social conflicts over resources (Frankema 2010, pp.447-448).

Since the seminal work of the political economist Schumpeter on the crisis of the tax state (1918), the importance of taxation has been increasingly recognized by many scholars in history, economics, political science, and law. Schumpeter is considered the father of fiscal sociology. He was the first scholar to theorize the emergence of modern tax states and stress the importance of interstate warfare for the transition from feudal property rights of princes to state formation and tax obligations of citizens. He analyzed how war became a public affair, to be financed by tax payers (Tunçer 2015). Later Tilly built on his arguments to analyze the determinants of fiscal capacity and the observed regional variation in Europe (1990).

In the $20^{\text {th }}$ century Europe, and especially after the financial crisis in 1929-30, Keynesianism posed taxation and welfare investments at the centre of macro-economics. In the era of consensus politics and the post-WWII economic boom, taxation was considered a major tool for wealth and income redistribution. After the 1973 oil crisis, when the principles of neoliberalism started to dominate, state interventions in the economy were severely criticised and public finance became the object of intense political and ideological debates (Buggeln et al. 2017). The instrumental role of the state in growth and re-distribution has been thoroughly investigated from a historical perspective by scholars such as Evans, Rueschemeyer and Skocpol (1985). Piketty (2014) also has considered taxation on capital income and wealth as the key policy tool of governments to combat rising inequalities worldwide.

The difference between macroeconomic or public finance studies and fiscal sociology is that the first usually perceive state as a rational actor that responds via fiscal policies to market failures, while the latter recognises the importance of non-economic factors interacting and ultimately shaping and transforming fiscal policies and practices (Campbell 1993, p.164). ${ }^{4}$ The "new fiscal sociology" has placed taxation at the center of social change, by considering taxation not only as a consequence, but also as a cause or engine of change (Martin et al. 2009). As a symptom of change, the development of fiscal institutions is an indicator for the development of state and economic institutions in general (Gardner 2013, p.131). As an

\footnotetext{
${ }^{4}$ Valuable theoretical contributions were made during the same period from a critical political economy perspective. For instance, neo-Marxist Poulantzas (1987) viewed the state as an actor "relatively autonomous" from economic forces.
} 
engine of change, taxation is the driving force of other state and social institutions, since it is tax revenue that funds sovereignty mechanisms and determines the size of central administration, defense forces, public goods and welfare services.

Most of the aforementioned scholars focus on the history of state formation and fiscal regimes in the so-called "developed world". The fiscal history of developing countries and especially of colonial Africa differentiates from the fiscal history of European and Asian sovereign states in many ways, as I explain in the following sections. However, without falling in the trap of Eurocentric determinism, there are certain dimensions worth to investigate from a comparative perspective and certain concepts worth to empirically test, in order to better understand the particular features of colonial fiscal systems in Africa.

Brautigam, Fjeldstad and Moore have turned their attention, first, to the impact of the revenue imperative on the broader institutional development and, second, to the effects of taxation on the state-society relations in contemporary developing countries $(2008$, p.3). These dimensions are relevant not only for independent Asian and African states but also for the colonial states of the past, as taxation was a significant instrument for state and institutional development also in the colonial context. Fiscal capacity was one of the main concerns of the new-born colonial states, which had to demonstrate "effective occupation" 5 and administration of their territories, to secure them at the negotiating table during the Scramble for Africa.

In the context of the Great Divergence debate, He (2013) engages in an extended spatial comparison and explains why China did not become a modern fiscal state, while England and Japan did. According to He, the differentiating factor was not military competition, but the credit crises (of the 1660s for England and of the 1870s for Japan and China) and the response of each state to them. He considers revenue centralization, debt creation, welfare investments and representative government as the main conditions of "fiscal modernization", which imply different levels of state strength or fragility and affect long-term economic development. This thesis explores these issues to a greater or lesser extent. How centralized were fiscal regimes and states in Portuguese Africa? Did the Portuguese African states allow for tax diversification, debt creation and welfare services expansion?

In a Schumpeterian social contract framework, taxation is the outcome of a historic bargain between the rulers and the ruled (Musgrave 1992). The level of consent from the side

\footnotetext{
${ }^{5}$ The principle of "effective occupation" was defined by the "General Act" of the Berlin Conference in 1884-85. The imperial powers were obliged to effectively possess the African territories that they claimed: they had to ratify agreements with native leaders, fly their flag and establish an administration with a police force to maintain order.
} 
of the governed and the level of progressiveness of fiscal systems have been connected to democratization. Democracy was by definition absent in colonial Africa. Representation of the governed and accountability of the governors were to a certain extent subject to change, but overall only a small minority of indigenous Africans had a say in colonial governance. Moreover, democratization presupposes the people's right to self-determination and the sense of nationhood ${ }^{6}$ (Rustow 1970), conditions which were not satisfied in the case of colonial Africa. In Africa national identities started emerging in the late colonial era and in the end contributed to the overthrow of colonial rule. Metropolitan powers attempted to moderately liberalize the political regimes in the late colonial era to prevent the development of African nationalist movements, however they did not succeed.

The concept of "semi-voluntary compliance" stemming from Levi's theory of predatory rule (1988) does not apply to colonial Africa, since the vast majority of tax payers were colonial subjects and did not practice tax compliance voluntarily to any extent. It was coercion rather than a combination of freedom of choice and potential sanctions that motivated native African taxpayers to comply with the rules of the colonial state. For all the aforementioned reasons, the social contract between Leviathan (Hobbes and Gaskin 1998 [1651]) and its subjects was deficient in colonial Africa.

In colonial Africa taxation was used by the colonial authorities not only as a revenue source to finance the operation of colonial states or extract profit for the metropoles, but also as a tool to enforce the capitalist mode of production in a context of "compulsory globalisation" (Hopkins 2002), foster socio-economic modernisation and reproduce power relations and consequently inequalities. ${ }^{7}$ Taxation has been viewed as a disciplinary tool (in Foucauldian terms) to "transform colonial subjects into governable persons" (Bush and Maltby 2004), "civilise" indigenous people, force them to work for wages and foster monetisation.

\footnotetext{
${ }^{6}$ In other words, democratization presupposes the sense of belonging to an "imagined community", as defined by Anderson (1987).

${ }^{7}$ Jamal (1978) argued that both direct and indirect taxation (on basic and luxury goods) imposed by the British authorities on African and non-African farmers and wage earners increased income inequality in Uganda. Also, Gwaindepi (2018) has concluded that during the $19^{\text {th }}$ century the public finance system in Cape Colony served the interests of the political and economic elites of the so-called "mineralsrailway-complex".
} 


\subsection{The colonial origins of state fragility}

There are certain political, military and socio-economic indicators, usually set by international organizations such as the United Nations, OECD and World Bank, that indicate the extent of state weakness or fragility. OECD defines "fragility as the combination of exposure to risk and insufficient coping capacity of the state [...] to mitigate those risks"(2016, p.21). The weakness or fragility of many African states is frequently indicated by conflict, violation of human rights, weak law enforcement, domestic political instability and external interventions, associated with demographic pressures and "bad governance" of post-colonial authoritarian regimes (Fragile State Index). Despite the observed growth of Sub-Saharan Africa over the last two decades, "the extent to which recent growth is also driven by improved governance" is debatable (Frankema and van Waijenburg 2018). The fragility of the two former Portuguese colonial states of Mozambique and Angola is currently considered to be at an alarming rate (Messner et al. 2016). ${ }^{8}$

An increasing number of scholars and development practitioners have criticized the concept of "fragility" and its application as an ideological construction used by powerful states to intervene in the affairs of countries of the so-called Global South (Woodward 2017, p.1). Apart from the ideological connotations of the notion of fragility and the political uses of the particular indicators, the present status of African governments and states is sometimes presented as a self-standing "independent variable" in the public and academic sphere (i.e. by Gilley 2017); regardless of any persisting trends and historical influences from the past. However, as a growing body of literature shows, historical determinants are crucial and need to be thoroughly studied: Colonial legacy as well as the influence of pre-colonial conditions have played a considerable role in the formation and performance of post-colonial African states and economies (Young 2012, Cooper 2002, Herbst 2000, Young 1994). Historical institutionalists have introduced the concept of "path dependence" that implies the dependence

\footnotetext{
8 "In 1981 the governments of Angola, Chad, Ethiopia and Uganda could not claim a monopoly of force within their jurisdictions" (Jackson and Rosberg 1982, p.12). Two decades later, Angola has no welfare legacy and is along with DRC and Sudan one of the most vulnerable states (Clapham 2001, p.10). Similarly, other scholars note that "Angola, which has the potential for rapid economic growth, instead exports refugees to neighbouring countries" (Ottaway et al. 2004, p.1).
} 
of present societies on a restricted set of institutional paths, historically determined (Olsson 2016, pp.18-20). ${ }^{9}$

To answer the question of why certain nations or states fail in the long run, some scholars have stressed the role of exclusive institutions (Acemoglu and Robinson 2013, Acemoglu et al. 2001). Others have examined pre-colonial institutions such as the political centralization of African kingdoms and ethnic groups (Michalopoulos and Papaioannou 2013, Gennaioli and Rainer 2007) as well as the concept and the reality of neo-patrimonialism and intra-African disparities (Englebert 2000). On the other side, some scholars have pointed at geography- and demography-related factors (Bloom et al. 1998) such as climate, soils and diseases (Diamond 1998) as ultimate causes of certain regions' underdevelopment. Pomeranz (2000) has highlighted the colonial exploitation of resource-rich regions, to explain divergences in development pathways at a global scale, for instance between Europe and China. Moreover, factor endowments (land, labour and capital) have been revisited by scholars in the context of Africa from a long-term perspective (Austin 2008a). All the aforementioned factors played a role in the state and economic transformations of former Portuguese Mozambique and Angola over the last two centuries.

One of the reasons that many African states are considered weak is that they lack ethnic and cultural homogeneity as well as socio-economic integration. Their borders were rarely drawn on the basis of pre-colonial African socio-political boundaries. While European states were identity-driven and were formed before their borders were defined, African states had to be formed after their boundaries were set (Clapham 2001, p.8). In other words, in Europe the empirical statehood preceded the juridical one, while in Africa the process of state building was reverse (Jackson and Rosberg 1982, p.23). In 1963 the Organisation of African Unity (OAU), founded by the newly independent African states, decided to maintain and respect these fixed borders, despite the heterogeneity of the African societies. Clapham (2001) has pointed at the paradox of persistent but weak African states: states in Sub-Saharan Africa have persisted although they have not fulfilled significant empirical conditions such as law enforcement and power legitimization. ${ }^{10}$ In this thesis I take into account geography,

\footnotetext{
${ }^{9}$ Mkandawire (2010) analysed the colonial origins of intra-African variations in fiscal capacity. To do this, he estimated tax effort (the ratio of collected tax revenue to the potential tax revenue, given a country's structural features) in 35 African countries.

${ }^{10}$ Jackson and Rosberg argue that the persistence of African states can be attributed to the juridical components of statehood (1982, pp. 16-17). More specifically, African states owe their preservation to the following conditions: the rising African nationalism called Pan-africanism that reinforced national identities; the vulnerability and insecurity of all African governments and leaders; and the recognition
} 
demography and pre-colonial institutions as explanatory factors, while I treat colonial fiscal and labour institutions as both outcomes and drivers for social change and state transformations (see 1.6).

\subsection{Extractive and developmental fiscal states. The case of Portuguese Africa}

Portugal maintained a long-lasting relationship with her colonies in Africa. The Age of Portuguese discoveries from the $15^{\text {th }}$ to the $18^{\text {th }}$ century has been identified with the first phase of globalization and the rise of merchant capitalism. The Portuguese created trade posts in the coastline of Sub-Saharan Africa long before Britain and France establish colonies and become Empires with growing power worldwide. In this thesis I am investigating the Portuguese Empire after the loss of Brasil in the 1820s (Clarence-Smith 1985) and the official colonization of Mozambique in the Eastern African coast and Angola, Guinea, Cape Verde, São Tomé and Príncipe in the Western African coast.

The transition from slave to commodity trade in the early and mid- $19^{\text {th }}$ century has been recently viewed as fertile ground for the Scramble for Africa. "The export boom was crucial in shaping an economic context in which the partition of Africa became politically defensible" (Frankema et al. 2017, p.233). The British and especially the French positively assessed the export boom of tropical commodities in the preceding period, which motivated them to compete for African and other territories of the "global periphery". The end of the trans-Atlantic slave trade and passage to legitimate commerce also affected the development of fiscal institutions in early colonial Africa. The metropoles gained net benefits via reexporting commodities and the colonial states increased their capacity to raise indirect taxation on export commodities. Clarence-Smith (1985) has shed light on the terms of trade and the economic motivations of imperial powers such as the search of Portugal for markets, that contributes to the understanding of the economic rationale of imperialism. ${ }^{11}$ In the case of

of the states' sovereignty rights by the international community, whose integration coincided with African independence. Neither domestic elites nor the international community supported reconfiguration of African states in the post-independence era (Clapham 2001, p.11).

${ }^{11}$ The main motives of Portugal to colonize and expand its control over African territories in the late $19^{\text {th }}$ century were: first, the economic importance of trade between the metropole and the colonies; second, the military competition between the imperial powers; and third, the national pride deriving from the belief that Portugal could still be one of them. The national pride and imperial prestige were particularly highlighted by Richard Hammond (1966), who argued for the "uneconomic" character of 
Portuguese Africa, the states continued to rely on customs and excises on minerals and cashcrop commodities such as rubber, cotton, sugar, coffee and tea until the early 20th century, when they began more systematically to collect direct taxes on property and income.

Portugal was not only the first European power to step on Sub-Saharan African soils, but also the last one to leave Africa and accept its defeat in the independence wars fought by liberation movements in the 1950s-1970s. Portuguese colonies declared their independence as late as 1975, despite the metropole's economic weakness. For this reason, Telo considers Portuguese Empire a "historical enigma" (1994b, p.347). Other scholars stress that the peripheral position of Portugal within the European scenery has obscured its role as a colonial power during the two last centuries (Diogo and van Laak 2016). How exceptional or representative was the case of Portuguese Africa in terms of colonial state formation, institutional building and fiscal development?

In British Africa, the "self-sufficiency" policy was adopted relatively early, implying the need for colonies to construct fiscal systems and fund their own administration, defense, public works and social services (Gardner 2012, pp.17-30). It was not only the metropole that determined the development of fiscal institutions in African colonies. Frankema and van Waijenburg (2014) compared British and French African colonies and concluded that local geographic and economic factors played a more significant role than metropolitan identity. ${ }^{12}$ Portugal was a weak and non-industrialized economy. Consequently, there was a pressing need for Portugal to encourage the financial autonomy of its colonies at an early stage. How did this affect the development of the domestic fiscal institutions (within the colonies)? This thesis shows how the agenda of a weak metropolitan power, as Portugal, and the local conditions coshaped the historical reality of the colonial states of Mozambique and Angola. By comparing the two main African colonies of Portugal, I shed light on the differentiating role of local geographic and socio-economic factors.

Portuguese imperialism. The argument of "uneconomic imperialism" was questioned by several scholars, such as Clarence-Smith (1979). The latter deconstructed the concept of "irrational nostalgia for imperial greatness" and gave prominence to the rational economic motivation of Portugal to claim its African territories, in view of the capitalist recession starting in the 1870s (Clarence-Smith, 1985, p.81). In this thesis Portugal's economic motivation and military competition are indeed prioritized over national pride. However, imperial prestige is also taken into account, since it played an essential role in the metropolitan ideological discourse.

${ }^{12}$ In the same vein, common patterns and variations in Francophone Africa have been studied by Anderson (2017) and the case of Belgian Congo has been investigated by de Roo (2017). In both studies, local socio-economic conditions and power relations mattered considerably for the development of fiscal systems and state (trans)formation. 
The question whether and to what extent African colonies burdened or benefited the metropoles remains. Davis and Huttenback (1986) as well as O’Brien (1988) argued that colonization was a burden on imperial economies and the subsidies provided by the metropoles to the colonies burdened the British and French taxpayers. Specifically, Davis and Huttenback (1986) showed that the British middle class principally bore the costs of maintaining an empire, while the aristocrats, civil servants and military elites benefited from it. The British Empire was seen as redistribution mechanism in favour of the metropolitan elites. On the other hand, Huillery (2014) accounts for the financial transfers between West African colonies and France and claims that the profit of colonization for the metropole was much higher than the cost of it. "Most revenues were collected on an African basis while being spent on a French basis" (ibid, p.6). Similarly, Lains (1998) has studied Portuguese imperial finance and showed that the net benefits for Portugal outweighed the costs of maintaining colonies in Africa.

Apart from the role of imperial transfers in the development or exploitation of the colonies, the question on the public revenue distribution within the colonies arises. Anne Booth has classified states depending on their fiscal systems and argues that most parts of late colonial south-east Asia corresponded more to a "developmental" than "night watchman" type of states, as presented by previous literature (Booth, 2007). Frankema also introduces a classification between "benign/benevolent", "night watchman/minimalist", "extractive" and "developmental" states and argues that British African states aimed at "minimizing effort" rather than at "maximizing revenue" (2011). ${ }^{13}$

Along the same lines, Frankema has concluded that in British Africa it was the failure to build efficient fiscal institutions rather than the extreme level of extraction that hindered economic development in the long-run (Frankema 2010, p.452). Undoubtedly, these classifications are based on ideal types, which are neither fully encountered in reality nor remain stable across time, since states and societies undergo historical transformations. In any case, each of these ideal types, for instance the "extractive" or "developmental" state, denotes a certain proportion between taxation and public spending that has important implications.

These ideal types can lead to arguments in favour of colonization or against it in the contemporary public and academic discourse. For a strand of scholars European colonization

13 Developmental states are characterized by maximum taxation and maximum public spending; extractive states signify maximum taxation and minimum spending; minimalist states indicate minimum taxation and minimum spending; while "benign" states imply minimum taxation and maximum spending (Frankema 2011, p.138). 
severely damaged and underdeveloped Africa (Rodney 1972), while for others it played a positive role and the long-term benefits for British and French colonies outweighed the damage. ${ }^{14}$ These benefits are usually associated with the building of states that promoted public investments in welfare services and infrastructure either subsidized by the imperial powers or funded by the colonial budgets. Do Portuguese states of Mozambique and Angola fit in one of the aforementioned types of fiscal states (extractive-minimalist-developmental-benign), depending on their fiscal policies and practices?

The work of scholars such as Isaacman $(1996,1972)$, Newitt $(1995,1981)$, Penvenne (1995), Vail and White (1981) have been cornerstones in the field of Portuguese African history, particularly with respect to agricultural production, commercialization, migration and labour affairs. Especially forced labour has been studied in depth by Allina (2012) and Ribeiro (2016), in the case of Mozambique, and by Ball (2015), in the case of Angola. Migration and land issues in both colonial and post-colonial era have been investigated by Castelo (2007), Tornimbeni (2012) and Direito (2013a, 2013b) respectively. Other issues such as welfare development in the late colonial era, named as "repressive developmentalism" (Jerónimo and Pinto 2015), have gained attention over the last years.

Although noteworthy efforts have been made to re-construct the reality of labour systems in Portuguese Africa, few have focussed on aspects of colonial administration and taxation (Havik 2013, Havik, Keese and Santos 2015). This thesis builds on previous work by discussing administration, direct and indirect taxation as well as wage and forced labour affairs in Portuguese Africa, while also bringing into the discussion the distribution of tax and nontax revenue via public investments in military occupation, new means of transportation and

\footnotetext{
${ }^{14}$ For over a century scholars have been divided with respect to the nature and impact of the imperialism on the colonies. Marx himself foresaw the destruction of indigenous manufacture via imposed free trade and the exploitation of cheap labour by the British rule in India (1853). However, he considered capitalism as a necessary stage for the industrial development and class formation in the global South. Right after the Berlin Conference, the Second International took place in 1889, where the views of Marxist thinkers such as Hobson (1965 [1902]) and Lenin (1917) on imperialism were discussed. Both considered the need for capital expansion as the main motive for imperialism. After several decades, Fieldhouse (1961) criticized their highly influencing arguments as empirically weak. Nevertheless, Luxemburg's theory on the imperialism of trade as "unequal exchange" between the colonies and the metropoles laid the foundations of the neo-Marxist Dependencia school in Latin America, which developed as a response to the dominant modernisation theory on the transition from traditional societies to modern ones and the dual-sector model invented by Lewis (1954). Core and periphery relations were seen by dependency theorists as a structural impediment to the development of the Third World (Gunder Frank 1967, Wallerstein 1986).
} 
social services such as education and health. In other words, this thesis brings to the fore the question of wealth and income redistribution via taxation, public investments and labour.

\subsection{Conceptual framework}

Despite the growing body of literature on state formation and fiscal regimes in British and French Africa, none to our knowledge has systematically examined the whole of fiscal regimes in Portuguese Africa, including public spending patterns. The objective of this thesis is to fill in this lacuna, by shedding light on a neglected region by English-speaking scholars in economic history of Africa. I conduct a twofold comparison from a long-term perspective: first, between the two main Portuguese colonies of Mozambique and Angola, by keeping the metropolitan identity constant; and second, between the Portuguese Empire as a whole with the British and French Empires. Furthermore, I cover more than a century of colonization and state (trans) formation, allowing a dynamic approach of how colonial states and fiscal regimes evolved over time rather than drawing static conclusions on "how things worked". I take into account the interplay between the imperial identity and the local conditions and contribute in the discussion on strong and weak states in colonial Africa.

The problematic aspects of implanted institutions have come to the fore by recent debates on state-building in post-conflict contexts in contemporary Africa. State institutions seem to function better when they are not imposed from above but grounded in the social structures (Boege et al. 2009). ${ }^{15}$ A shift from essentialist (Weberian) approaches to more empirically-embedded (Tillyan) ones brought up the issue of the weak states' strength (Meagher 2012, p.1077). For instance, the weakness of local or informal forms of governance (such as traditional authorities or guerrillas) might evolve into a strength, if these forms gain popular legitimacy. Examples such as the post-colonial "informal" state of Somaliland show, first, that state or institutional strength and weakness are relative phenomena and, second, that they are dynamic processes subject to change rather than static features.

This thesis investigates the "strong-weak state paradox", by focussing on the strong states' weakness or on the weak states' strength, depending on one's perspective. Imperial

\footnotetext{
${ }^{15}$ Models of "good governance" and other top-down manual-style guidelines on how to construct a strong state have been recently criticised by scholars such as von Trotha, who characterized them as arrogant managerialism that allows historical amnesia to prevail in both academia and politics (2009, p.39).
} 
powers and colonial African states could be seen as either strong or weak in certain aspects, both in the international arena and within their jurisdiction (see figure 1.1). I argue that Portugal widely used coercion mechanisms such as native taxation and forced labour to enforce law in its African colonies, exactly because it was weaker than the other metropolitan powers in economic and diplomatic terms. The strength of Portuguese states of Mozambique and Angola stemmed from coercion and not from the consent of the governed population. This type of state strength was actually a sign of weakness. The colonial legacy and the role of this paradox in state fragility in post-colonial Africa is implicitly touched upon in this thesis, which serves only as a starting point for further research on this topic.

My conceptualisation of the metropolitan and the colonial African states has been influenced by the work of Solli and Leysens (2011) on "the strong/weak state contradiction" in post-colonial Angola, where state strength and weakness are approached from both a neoWeberian and a neo-Gramscian, historicist perspective. Neo-Weberian scholars such as Jackson and Rosberg (1982), Clapham (2001) and Rotberg (2004) refer to an ideal type of developmental state and the more an African state resembles to this ideal type the stronger it is (ibid, p.299). In the world order the state draws its strength from its geo-political power and economic performance. Within the state territory, its strength is indicated by its capacity to offer security and enforce law. Neo-Gramscian historicists such as Mamdani (1996) and Bayart (1993) take into account the interaction between state and society, which they consider as dynamic and "subject to change" (Solli and Leysens 2011, p.301). In this analysis, consent of the governed is a crucial source of strength for the state. Therefore, the state seeks to pass from dominance to "hegemony" 16 , by reducing coercion and increasing consent.

If we adopt the neo-Weberian reasoning, the post-colonial state of Angola is "a paradoxical case of a state which is both weak and strong" (Solli and Leysens 2011, p.297), since it is rich in resources and highly militarized, with an exceptional performance in oil exports. However, it lacks the capacity to foster inclusive development within its jurisdiction (ibid, pp.306-307). In a neo-Gramscian framework, post-colonial Angola is a coercive state. This study builds on a synthesis of neo-Weberian and neo-Gramscian approaches by considering the power of the state in the world order, the coercion within the state territory and

${ }^{16}$ For Gramsci the term cultural "hegemony" refers to the cultural institutions and ideological mechanisms that the ruling class or the state uses to maintain power in capitalist societies (Gramsci et al. 1971, Mouffe 2014, p.168). In this thesis I do not explore how the imperial powers or the colonial states used ideological institutions such as education to re-produce their power in Africa. However, apart from military force, I do investigate means of indirect dominance such as technological progress and infrastructure development. 
the consent of the society as complementary sources of state and fiscal capacity. I aim at highlighting the colonial origins of this "paradox" and showing the (unsuccessful) attempt of the Portuguese states in Africa to shift from "effective occupation" to development over time. I argue that exactly because Portugal was a weak colonial power, compared to Britain, France or even Belgium, it introduced coercive fiscal and labour institutions to establish its rule.

The conceptual model below depicts the underlying factors that contribute to the (trans) formation of Portuguese African states. These factors determine the states' strengths and weaknesses both in the international arena and within the states' jurisdiction. They correspond to the research objectives that I attempt to address in each of the following chapters. First, I deal with the question on the influence of the metropolitan identity and policies over time: Portugal was a non-industrialized country, with limited geo-political power throughout the colonial era ${ }^{17}$. Depending on which political regime was in power, the metropole adopted different colonial policies concerning centralisation or autonomy as well as debt. Specifically, Republicans (1911-1926) fostered the administrative and fiscal autonomy of the colonies and allowed debt creation, while Salazar's New State fostered centralisation and austerity (see chapter 2).

Second, I examine the role of local conditions, such as lack of socio-economic integration, in the case of Mozambique. Also, I show how institutionalized migration and forced labour contributed further to a fragmented colonial state and increasing fiscal inequality. (chapter 3). Third, I compare Portuguese Africa with British Africa and explain why Portugal severely invested in the securitization of its colonies, especially during the early phase of colonization. The reasons had to do with Portugal's insecure position in the imperial spectrum and the natives' resistance, particularly in the case of Angola. By highly investing in military forces, the colonial states of Mozambique and Angola achieved to a certain extent law enforcement but failed to deliver welfare services (chapter 4).

Fourth, I investigate infrastructure and transportation investments in Portuguese Mozambique and Angola. For both Portugal and its colonies access to private capital and credit markets was limited. In the 1930s, new means of transportation such as railways were mostly taken over by the Portuguese African states. Railways were used as means to complete occupation and attain power legitimisation by increasing consent of the governed population

\footnotetext{
${ }^{17}$ As late as 1950, "the primary sector (agriculture, fishing, forestry) absorbs about 50\% of Portugal's manpower. Industry accounts for only $24 \%$. The tertiary (white-collar) sector employs the remaining 26\%." (Anderson 1962, p.85).
} 
(chapter 5). In the aforementioned processes of revenue collection, securitization and infrastructure expansion, the Portuguese African states used (more or less intensively) coercive and extractive institutions such as native taxation, forced labour and military recruitment. The transition from dominance to hegemony and from coercion to consent remained sketchy.

In other words, the extent to which the metropolitan and the colonial states were strong or weak led to differential institutional responses throughout the colonial era. In certain periods, the metropolitan and colonial states used extractive, minimalist or developmental fiscal institutions. Both international turning points and junctures within the Portuguese Empire, such as regime changes, co-shaped the institutional responses of the Portuguese fiscal states in Africa. Nevertheless, I don't see these institutional responses only as a final outcome of the states' strengths and weaknesses at international and domestic level. In this thesis I also aim at showing how the fiscal (and labour) institutions re-affected the states' qualities, making them stronger or weaker in the long run. For instance, chapter 3 shows that the extensive use of forced labour was an institutional "response" by Portugal, being a weak metropolitan power and lacking the resources to mobilize wage labour and raise taxes in a monetized way; and at the same time it was a factor that weakened further Portuguese Empire, since the co-existence of different labour systems and production zones in Mozambique under state or company rule damaged the integration of the colonial economy and fiscal administration.

I divide the colonial era into four periods, each of which is characterized by the domination of a distinct type of fiscal state (minimalist-extractive-developmental) in Portuguese Africa. Table 1.1 shows that each period is marked by certain international ruptures and domestic changes (within the Portuguese Empire). The early colonial era is characterized by a combination of minimalist and extractive fiscal systems in Portuguese Mozambique and Angola, that aimed at either securing order at the minimum cost or extracting resources such as indigenous labour and taxes. On the other hand, the late colonial era is indicated by an incomplete transition from fiscal minimalism to developmental concerns, that were never fully addressed.

I consider Portuguese African states and fiscal regimes under Salazar's governance as in principle "minimalist", due to the centrality of the fiscal balance dogma at that time. However, my analysis does not underestimate the coercive nature of native taxation and labour during that period. In this sense, I share Anderson's statement on Portuguese Empire under Salazar: "the logic of economic archaism, brutal exploitation and omnipresent foreign capital is a political regime of permanent violence. Only a massive machinery of repression could 
keep the whole intolerable structure in place." (1962, p.88). Therefore, I conclude that the concept of "extractive minimalism" is the most suitable to grasp the contradiction between minimalist policies and extractive practices as well as the exceptionality of Portuguese Africa from institutional perspective. 

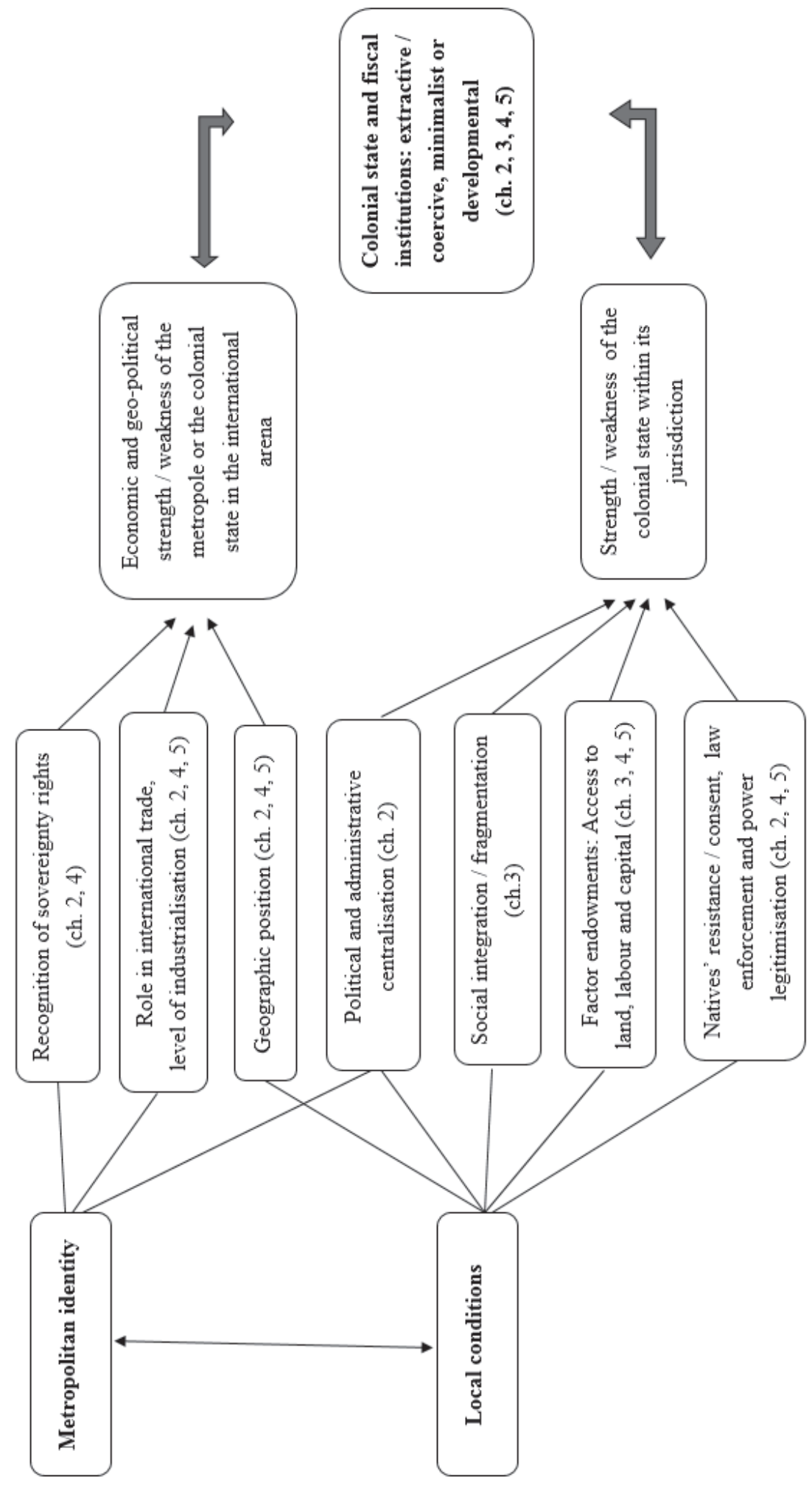


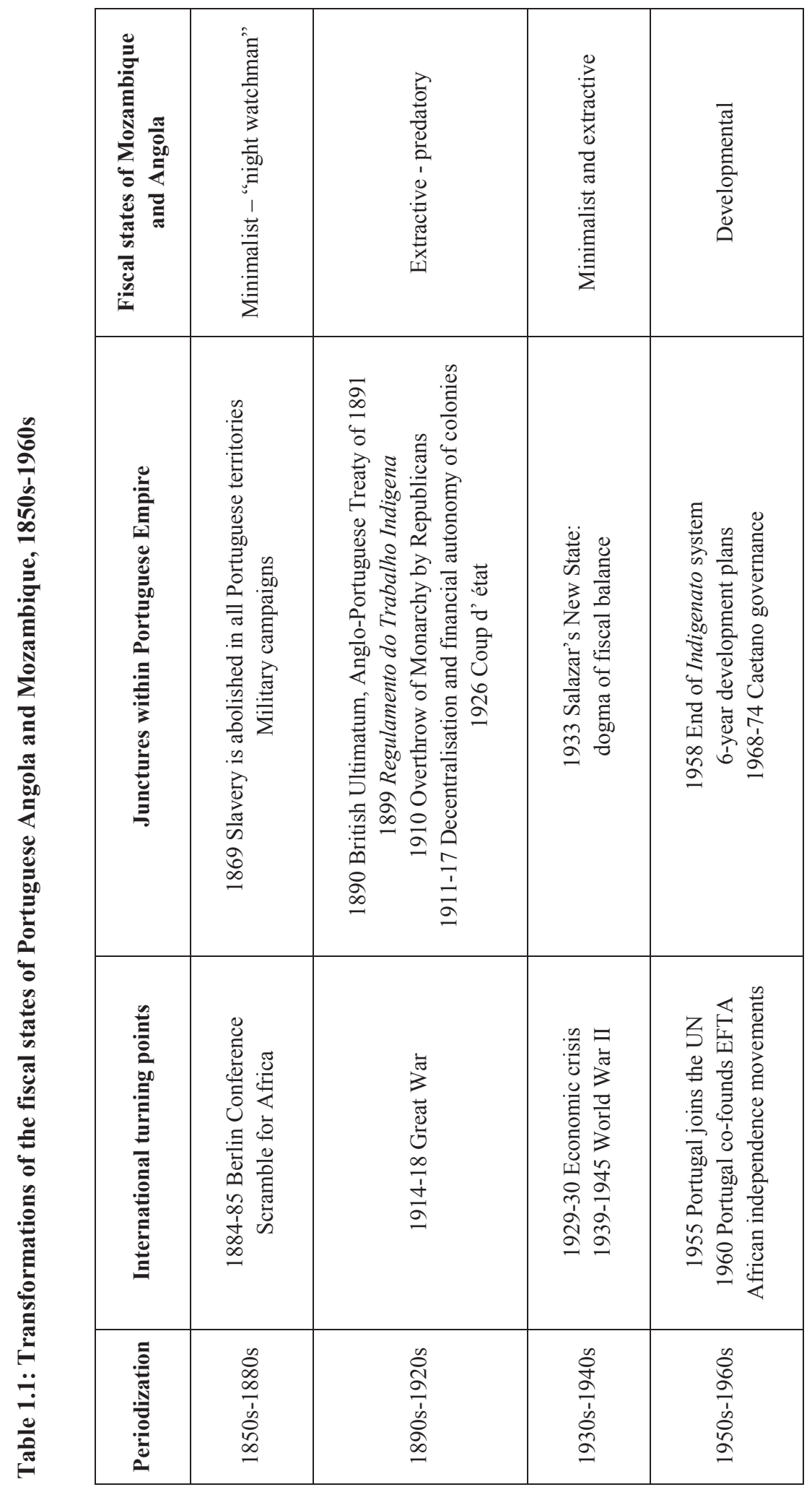




\subsection{Methodology and sources: limitations and possibilities}

\section{Economic history in light of political economy}

Most classical political economists of the $18^{\text {th }}$ and $19^{\text {th }}$ centuries, such as David Ricardo and Adam Smith, would agree that "political economy informs us of the laws which regulate the production, distribution, and consumption of wealth (Mill 1844, V.10). In their critique, Marx and Engels posed class struggle at the center of political economy and analyzed how ownership of the means of production and surplus extraction influenced historical processes (1970 [1859]).

Economic history is not simply the history of economies, as a descriptive listing of historical events in the course of economies. The contribution of Annales historiography is decisive in bringing forward more basic structures instead of central historical events (ClarenceSmith 1977). Resource endowments (land, labour and capital), production and trade relations as well as distribution mechanisms matter as explanatory factors of diverse development pathways. In this sense, economic history is not simply the intersection of history and economics. It is the political economy of past and present societies. It involves driving forces and outcomes, the continuous interaction and bargaining of a wide range of historical actors with different interests.

Economic history in light of political economy can rise above the fragmented historical reality that post-colonial theory cultivates, in its attempt to de-construct the cultural legacy of colonialism. Post-modern and post-colonial studies have over-emphasized the role of symbolic representations, ideologies, identities, subjective memories and sentiments of "subaltern peoples"; leaving behind any material concerns. I stand with Chibber's critique (2014) that a universalizing theory does not necessarily need to suffer from Eurocentrism or reductionism. Interdisciplinary synergy between social sciences and humanities can offer the most fruitful responses to the aforementioned "threats" and reverse them into opportunities.

In this thesis I approach colonial states and fiscal regimes without overlooking that these impersonal entities consisted of tangible structures and institutions that reflected and reproduced or challenged the power balance between multiple historical actors with more or less or no resources. 


\section{The comparative method. Quantitative and qualitative analysis}

The formation of colonial African states and the historical transformations of their fiscal regimes are long-term and complex processes. Which are the most fruitful methodologies and tools to interpret long-term developments, diverse pathways and causal mechanisms? In this study, I use the comparative method. I conduct a long-term multi-level comparison between colonies (Mozambique and Angola) and Empires (Portuguese and British Africa), to extend the spatial and temporal horizons of previous studies on colonial state formation and fiscal regimes. I emphasise dynamics and transformations, challenging static perceptions of historical reality. By showing that path dependency matters, I challenge public (mis)conceptions on state failure in Africa and its causes.

Quantitative tools such as statistics and econometrics are useful, because they can explore statistically significant relations and result in long-term observations. However, quantitative methods are not sufficient by themselves; historical contextualization is needed to attribute meaning to these observations. Over the last three decades social sciences have been dominated by economic models that sometimes over-generalize and seem to function in a historical vacuum. The application of such models sometimes has severe policy implications on the development of societies.

Systematic research of primary and secondary sources is required, to examine the drivers of state strength and weakness in the case of Portuguese Africa as well as demonstrate the transformations of fiscal regimes over time. To this end, both quantitative and qualitative data have been collected from various historical archives located in Portugal and Africa. Quantitative data provide us with the overall picture of long-term trends in revenue raising and public income distribution in the two main Portuguese colonies of Mozambique and Angola, while qualitative information contributes to the contextualization of these trends and to the deeper understanding of the key explanatory factors.

For the historical narrative, qualitative information derives from colonial administrative and legislative reports (relatórios) issued by the Portuguese government, the Ministry of the Overseas (Ministerio do Ultramar) and the higher levels of colonial administration (governador-geral, distrito) in Mozambique and Angola as well as from correspondence between colonial officials and representatives of the metropole. I retrieved most of these reports and letters from the Overseas Historical Archive (Arquivo Historico Ultramarino) and the National Library (Biblioteca Nacional) in Lisbon. Furthermore, I collected valuable material on colonial policy debates at the library of Lisbon's Geographic Society (Sociedade 
de Geografia de Lisboa), which was the main Portuguese "scientific" think-tank on colonial affairs from 1876 onwards. Especially with respect to geo-political and military affairs, the issues of Revista Militar proved a rich source of information.

However, reports and evaluations conducted by low-ranked officers of the colonial administration originate from the Historical Archive of Mozambique (Arquivo Histórico de Moçambique) in Maputo. Moreover, I retrieved reports and correspondence on migration labour -from southern Mozambique to the Rand mines- from the National Archives of South Africa in Pretoria. Also, fragments from the Arquivo Salazar and the archives of chartered companies, such as the Companhia de Moçambique, located at the Arquivo Nacional Torre do Tombo, offered us an overall picture of the role of concession companies in tax collection and of the policy shift after the establishment of Salazar's "New State" in Portugal. Finally, I studied several essays, memorials and biographies of the colonial era at the Library of ISCSP (Instituto Superior de Ciências Sociais e Politicas). ${ }^{1}$

For the quantitative part of this study, I constructed datasets of annual time series on colonial state budgets and accounts at national and district level, to investigate long-term continuities and ruptures in revenue composition and public investments in Portuguese Mozambique and Angola. Both the principal sources of public income and the investment priorities of the colonial states are presented in absolute and relative terms. The revenue sources have been broken down in sub-categories, such as indigenous and non-indigenous taxation, and expenditure has been aggregated into three broad categories: expenditure on security resources, on infrastructure development and on social services. Security resources include fiscal and justice services as well as military and marine forces. Infrastructure development includes public works and agriculture projects, while social services include retirement pensions and civil administration services such as education, health and indigenous assistance. $^{2}$

\footnotetext{
${ }^{1}$ Other primary documents and part of the secondary literature were retrieved from: The Arquivo Militar and the Library of the Instituto Superior de Economia e Gestão in Lisbon, The National Archives (TNA) and the British Library in London, the Library of School of Oriental and African Studies (SOAS) at University of London, the Library of African Studies Centre (ASC) at Leiden University in the Netherlands, the Special Collection on Africa south of the Sahara at Frankfurt University Library and the Library of Congress in Washington DC, United States.

${ }^{2}$ In Frankema 's classification of expenditure in British Africa (2011) general administration is considered a sovereignty mechanism and thus is part of the security resources. In contrast, according to the classification adopted by the Portuguese in Mozambique and Angola, general administration consists mainly of education and health services. Therefore, in this thesis "civil administration" services have been accounted as part of the social services. Consequently, spending on social services has been slightly
} 
From the 1910s-20s, the colonial administrations in Mozambique and Angola were well established and kept detailed data on their colonies. Specifically, statistical data on population, taxation, and public expenditures were collected from the sections Demografia and Administração pública in the Statistical Yearbooks of Mozambique and Angola. Also, data from alternative sources were collected, to triangulate the retrieved information for the period 1910s-1970s, such as: Orçamentos gerais (general budgets), Contas da gerência (management accounts) and Bolletim de Fazenda (finance bulletin). In particular, orçamentos show how the budgets were planned by the colonial states and contas show the actual revenue and expenses of the colonies. Most of these documents are available at the National Institute of Statistics (Instituto Nacional de Estatistica) in Lisbon. In contrast, statistical data on the early colonial era (1850s-1910s) are relatively scarce, fragmented and presented mostly on aggregated (national) level. The bulk of information on annual colonial budgets and a rough estimation of metropolitan transfers derives from a series of issues of the Boletim Official available at the Overseas Historical Archive (Arquivo Historico Ultramarino) in Lisbon. ${ }^{3}$

To compare revenue sources and spending patterns in the two colonies as well as in Portuguese Africa as a whole vis-à-vis British Africa ${ }^{4}$, per capita revenue and expenditure have been estimated. For this purpose, I use the reconstructed population data provided by Frankema and Jerven (2014). However, the aforementioned dataset informs us only about the population of African colonies at national level. At district level, I use the population data provided by colonial censuses. ${ }^{5}$ The Portuguese censuses probably underestimate populations of

overestimated, while expenditure on security resources has been slightly underestimated. If I take this into account, then my argument in the fourth chapter on the extreme securitization of Portuguese Africa and the underinvestment in social services is further strengthened.

${ }^{3}$ In the case of Mozambique complementary information on public revenue during the first two decades of the $20^{\text {th }}$ century has been retrieved from a single yearbook named as "Anuario de Mocambique" (1908) and a couple of volumes of "Anuario Colonial" (1916-1917 and 1927-29).

${ }^{4}$ The amounts in Portuguese and African currencies (Portuguese Reis, Mozambican Escudos, Angolares etc.) have been either converted into pounds, based on the exchange rates offered by Valério and Tjipilica (2008) or have been deflated, so the effect of inflation on values can be minimized. For the annual series starting from the 1920s I have constructed a WPI (wholesale price index), using the Portuguese price index provided by Mitchell (2008) for the period 1927-1948 (with 1929 as base year) and for the period 1949-1987 (with 1954 as base year), while I have extrapolated the numbers for the rest of the years. Then the series of the nominal values were divided by the index, resulting in the real values. For the early colonial years I used the CPI (consumer price index) provided by Valério and Tjipilica (2008) and Valério (2001) for both Portugal and her colonies and I extended my deflated series further in the past.

${ }^{5}$ In the case of Mozambique censuses were frequently conducted throughout the colonial era. In contrast, in the case of Angola population estimations are considered to be reliable only in the late colonial era, 
Mozambique and Angola for two reasons: first, colonial administration lacked capacity to effectively occupy the whole of the territories at stake; and second, often colonial administrators, by recording less population, attempted to justify low performance in revenue raising and thus, avoid responsibility for tax collection in remote areas.

During my study, I was confronted with two limitations: one methodological or analysis-related and one technical or process-related. First, there is a danger to fall into the trap of telling a non-balanced, one-sided story, because I base my arguments on data retrieved from colonial reports and statistics. I have access to information almost exclusively produced by the colonial administrations of these territories. We need to critically read all the aforementioned sources to avoid re-producing the historical narratives of the colonialists. We need to be aware of and de-construct the racist or nationalistic stereotypes and preconceptions of the ones who administered the colonial states and the chartered companies and kept track of their fiscal accounts. Especially with respect to the early phase of colonization, there is no possibility of interviewing and giving voice to other historical actors such as indigenous people or white settlers. Concerning the late colonial era, oral history and ethnographic projects are valuable in overcoming this challenge. In this context, further research on how colonial subjects perceived taxation and state investments would be rewarding.

Last, researchers should be aware of the time constraints evolved in this type of research. Most of the documents in the Portuguese archives have not been digitized yet. INE (Instituto Nacional de Estatistica) is currently making an effort to foster digitization, which will eventually facilitate future researchers. However, other Portuguese archives have not taken such initiatives. The same applies to the National Archives of South Africa. In contrast, the series of African Blue Books have been already digitized by the National Archives in London. As a result, research on Portuguese colonies is more time-consuming than research on British colonies. Finally, the research potential of AHM (Arquivo Histórico de Moçambique) is immense, but digging into it demands considerable amounts of time. The documents are not registered into digital inventories and catalogues are still handwritten. In other words, it resembles a treasure waiting to be found.

from the 1940s census onwards. Therefore, backward projections (based on a given growth rate) were used to calculate population during the preceding period (before 1940s). 


\subsection{Scientific and social relevance}

This study draws value from analysing primary empirical evidence and re-visiting theoretical views and arguments on state formation and fiscal regimes in colonial Africa. It surpasses Eurocentric approaches to state formation and fiscalization and focusses on a Lusophone region that is often overlooked by the mainstream Anglophone literature.

It shows how resistance to institutional change, for example from forced to wage labour or from securitization to welfare, did not pay off to states (see chapter 3). It points at the importance of resources and questions the credibility of popular dichotomies between "benign" and "evil" cultures, i.e. British versus Portuguese or the reverse (chapter 4). Moreover, it highlights that infrastructural development and technological progress, such as new means of transportation, could be beneficial but might also imply suppression for the majority of the population (chapter 5). In this sense, development and progress are neither neutral nor uniform notions and realities.

In parallel, throughout this thesis I show that multiple historical actors (such as metropolitan decision-makers, colonial officials, chartered companies, white settlers, local chiefs and native taxpayers) with different degrees of economic, political and military power interacted and bargained. On the one hand, I subtly challenge dualist frameworks, i.e. modern vs traditional or rulers vs ruled. On the other hand, I do not discard the significance of representation and power. I demonstrate that the aforementioned actors had agency, but they were far from equal and acted within a restricted set of structures. For instance, many indigenous Mozambicans had the possibility to choose between working in railway construction, growing cash-crops, migrating to the Rand mines or revolting. However, lack of representation as well as coercive fiscal and labour institutions set strict limits to their agency and bargaining power.

This study is not only relevant for historians but also for policy makers and developmentalists. State and fiscal capacity building is often the subject of discussions within the field of international development. Sometimes past interventions are unfortunately overlooked and re-inventing the wheel becomes the norm. Studying the nature and effects of colonial interventions in state and fiscal institutions in Africa can prevent domestic policy makers and foreign agents from adopting a "neo-colonial" approach or simply repeating the same mistakes. 


\subsection{Thesis outline}

Chapter 2 provides an overview of the fiscal policies and practices in Portuguese Mozambique and Angola from the 1850 s to 1970 s. It discusses the constraints to fiscal centralization and unification and shows how colonial investments prioritized security, administration and infrastructure over welfare services. I argue that local conditions, including the 'pre-colonial' history of Portuguese-African relations, restricted possibilities of fiscal modernization, while major regime changes in metropolitan politics, such as the Salazar's authoritarian New State, were crucial in the re-organization of imperial finances.

Chapter 3 builds on Samir Amin's (1972) division of the African continent into three "macro-regions of colonial influence" with distinct socio-economic systems and labour practices: Africa of the colonial trade or peasant economy, Africa of the concession-owning companies, and Africa of the labour reserves. I claim that Mozambique incorporated all three different "macro-regions" in a single colony (north-center-south). I reconstruct state revenue raised at a district level between 1930 and 1973 and find persisting differences in the "tax capacity" of the three regions throughout the colonial era. The tax systems developed in response to existing local geographic and economic conditions, particularly to labour practices. Portuguese rule reinforced coercive labour institutions such as migration and forced labour to maximize revenue.

Chapter 4 investigates how differences in geo-political power of European metropoles affected colonial state formation. It presents the results of a thorough comparison of military capacity building in Portuguese and British Africa from 1850 to 1940. I test the thesis that Portugal, as an imperial "jackal", had to invest heavily in the securitization of its colonies to guarantee internal order as well as its external status against imperial "lions". I claim that the colonial governments of Angola and Mozambique could not benefit from similar economies of scale sustaining security systems in British Africa. The chapter demonstrates that armed forces absorbed considerably larger parts of the colonial state budget in Portuguese Africa and required substantial grants from the metropole, minimizing the resources available for welfare investments. It shows that armies were larger in Portuguese Africa and that military recruitment relied extensively on coercive institutions.

Chapter 5 examines the construction of new means of transportation, such as railways, that was initiated by the imperial powers during the Scramble for Africa (1880s-1890s). Railways aimed at penetrating into the hinterland, spreading settlements, facilitating mineral trade and fostering cash crop economies. By studying the chronological order, construction 
speed, operation and financing of the railway lines in Portuguese Mozambique and Angola, this chapter reveals the different priorities of the actors involved (concession companies, investors, metropolitan and colonial governments). Railways were expensive investments. Portugal was a weak economy and had limited access to international capital and credit markets. Therefore, most lines passed under state control at an early stage and were funded out of the colonial budgets. To this end, both colonial states and especially Mozambique relied heavily on extractive institutions such as indigenous taxation and coercive African labour. 


\title{
Chapter 2
}

\section{Local Conditions and Metropolitan Visions. Fiscal Policies and Practices in Portuguese Africa, 1850s-1970s ${ }^{6}$}

\begin{abstract}
This chapter surveys the fiscal policies and practices in the Portuguese African colonies of Mozambique and Angola from the 1850s to 1970s. It explores the fiscal implications of a long history of trade relations and cultural exchange, including early forms of colonial settlement (merchants, missionaries, prazeros), which were moulded into a relatively late and severely contested occupation wave in the late $19^{\text {th }}$ nineteenth century. It discusses the constraints to revenue centralization and fiscal unification and shows how spending policies prioritized security, administration and infrastructure over welfare services. I argue that local conditions, including this specific 'pre-colonial' history of Portuguese-African relations, limited possibilities of fiscal modernization, while major ruptures in metropolitan politics (e.g. the
\end{abstract} Salazar authoritarian regime) were key in the re-organization of imperial finances.

\footnotetext{
${ }^{6}$ A version of this chapter is accepted for publication as Kleoniki Alexopoulou (2018, forthcoming). "Local conditions and metropolitan visions. Fiscal policies and practices in Portuguese Africa, 1850s1970s". In: Ewout Frankema and Anne Booth (ed.). Fiscal Capacity and the Colonial State in Asia and Africa, c. 1850-1960. Cambridge University Press.

Acknowledgement note: I would like to thank Ewout Frankema, Elise van Nederveen Meerkerk, Maciel Morais Santos, Filipa Ribeiro da Silva, Barbara Direiro, Leigh Gardner, Philip Havik, Nuno Valério, Anthony Gerald Hopkins, William Clarence Smith, Corrado Tornimbeni, Anna Maria Gentili and Dácil Juif. I also owe deep gratitude to Diogo Paiva for his assistance in data collection; to the participants of the 9th New Frontiers in African Economic History Workshop at London School of Economics (October 2014); to the participants of the World Economic History Congress "Diversity in Development" in Kyoto (August 2015); and to the participants of the workshop on Lusophone Africa in World Politics at Bologna University (May 2017) for their insightful comments. Last but not least, I am grateful for the financial support provided by the Netherlands Organization for Scientific Research (NWO) as part of the VIDI project "Is Poverty Destiny? Exploring Long-Term Changes in African Living Standards in Global Perspective". The usual disclaimer applies.
} 


\subsection{Introduction}

Three major developments spurred Portuguese interests in Central Africa during the midnineteenth century. First, Portugal was severely damaged by Brazilian independence in 1822. For most of the 18th century, over fifty percent of Portuguese state revenues had been derived from Brazil (Maxwell 2000, p.1). It was hoped that an extension of the Portuguese strongholds in Central Africa could compensate for part of this loss. Second, the abolition of the slave trade in 1836 and the international ban on slavery in 1876 dealt another blow to the Portuguese economy. Portugal and Portuguese Brazil were the largest slave traders in the Atlantic world and the transfer of slaves from Angola to the mines and plantations of Brazil accounted for an overwhelming share of the colonial budgets (Capela 1979, pp. 85-86, Lains 1998, p. 236). At the same time, Britain gained ground by the expansion of legitimate commerce, the shift to steam shipping and increasing exports of industrial commodities and financial services during the nineteenth century. Expansion in Africa was part of a strategy to curb the growing British domination in the southern hemisphere (Newitt 1995, p. 333). Third, there was an emerging bourgeoisie in the urban centers of Portugal - Lisbon and Porto in particular - with roots in the banking and trade sectors. This group gained political influence and lobbied continuously for new industrial investments and the promotion of capitalist entrepreneurship (Clarence-Smith 1979, p. 167, 170). In their view, Africa offered opportunities for such capital investments, if the Portuguese government would stimulate the exploration of Africa's interior resources and develop institutions to regulate wealth extraction (Newitt 1995, p. 334).

These three factors in combination with the increasing threats posed by King Leopold's explorations in the Congo and German incursions in the south of Angola during the 1880s, created a need to safeguard the informal Afro-Portuguese trade empire through a more direct exploitation of African resources (Newitt 1995, p. 332). At the Berlin Conference (1884-85) the Portuguese stressed that their claims to Central African territory were based on prior discovery and a long-term presence in the region. Yet, the principle of "effective occupation" prescribed that territorial claims had to be backed up by treaties with local leaders, by waving flags and by the establishment of an administration and police force to keep order (Herbst 2000, p. 71-72). With the benefit of hindsight, these visions of a unified Central African territory under Portuguese rule, connecting the Atlantic with the Indian coasts, proved illusionary. The political negotiations with Britain about overlapping territorial claims were never an equal game. Britain ruled the waves, while Portugal had lost a great deal of its former imperial power. The costs of occupation pressed hard on its impoverished economy. 
Indeed, Portuguese-African trade relations had deep roots in what later became Angola and Mozambique. ${ }^{7}$ The Portuguese were the first to arrive in Central West Africa, and already in the sixteenth century the king of the Kongo kingdom converted to Christianity. The Portuguese dominated the slave trade south of the equator and drew parts of the Eastern coast of Central Africa into the trans-Atlantic slave trade during the second half of the seventeenth century (Klein 2010). Portuguese merchants settled at the coast, albeit in small numbers, and some also went further inland to establish plantations in the central zone of Mozambique under the so-called prazo system (see below, p.42). Yet, Portugal was forced into a scramble for vast hinterlands stretching beyond the coastlines where most of their trade had concentrated. The Portuguese government knew that if it waited to move, other European nations would stake out their claims. British fears of French and German incursions gave Portugal some room to maneuver, but the occupation involved significant warfare and went against considerable vested interests. This context of contested occupation shaped the evolution of a specific "Portuguese African" colonial fiscal system.

The military and economic competition extended far beyond the negotiation tables in Berlin. On the ground, private concession companies such as the Companhia de Mocambique and the British South Africa Company aimed to get access to mineral deposits in the areas of Zambezia, Manica and Sofala. The efforts of the Company of Mozambique to reach an agreement with Rhodes' BSA Company also helped the negotiations between the metropolitan powers. This conflict pushed the Portuguese authorities to develop a vision on colonial administration which was closely aligned with the British 'model' of indirect rule through concession companies. It also spurred investments in military and administrative capacity and infrastructure to defend Portugal's territorial claims against the British (Costa 1902, p.9).

There are four specific features of fiscal state formation in Portuguese Africa that I highlight in the remainder of this chapter. First, a central colonial budget had existed from 1845 onwards for Angola and 1854 for Mozambique (Governo Geral da Provincia de Moçambique, various issues 1850-1910), but the process of revenue centralization only gained steam in the early $20^{\text {th }}$ century. ${ }^{8}$ Second, even though custom revenues, as in most other African colonies, were the single biggest item of state revenue, the revenue mix did contain some categories that

\footnotetext{
${ }^{7}$ Throughout this chapter I will refer to the territories of Angola and Mozambique using the names they obtained under colonial rule. I am aware of the anachronism. I will use more specific geographic indications when the context requires.

${ }^{8}$ In the metropole, centralization and regulation of government accounts was achieved by 1859 (Dincecco 2011, p. 22). However, budgets of Portugal were already published in Diario do Governo since early 1820s: https://dre.pt/web/guest/conheca-o-diario-da-republica
} 
were more common to Asian colonial fiscal systems than to colonial Africa. These included a corporate income tax, a range of sales taxes and excises and an urban property tax. ${ }^{9}$ Third, Portuguese African states were highly militarized states. Even though the governments of Angola and Mozambique were certainly not among the poorest in colonial Africa in terms of comparative per capita revenues, the share of welfare spending (i.e. health and education) remained low and only expanded modestly during the First Portuguese Republic (1911-1926) and after 1950. Security, infrastructure (also serving security objectives) and administration remained the key spending categories, and especially military spending remained high up to the 1930s. Fourth, even though many colonial economies included poorly integrated production and trade enclaves, fiscal unification in Portuguese Africa proved very complicated, and was actually never achieved in Mozambique. The civil wars that devastated both countries in the immediate post-colonial era reflected this lack of integration (Newitt and Tornimbeni 2008, Alexopoulou and Juif 2017).

This chapter investigates in a largely chronological order how colonial fiscal policies and practices evolved, and how these were shaped by local conditions as well as by regime changes in Portugal. I will present data from primary and secondary sources to reveal the main trends in taxation and expenditure and highlight the main differences between Angola and Mozambique. The period under examination spans from the later settlements of Portuguese merchants and land owners in the mid-nineteenth century under the prazo-system (in central Mozambique), to the official incorporation of the two colonies into the Portuguese Empire in the 1890 s, to the shifts of power in Portugal in the 1910s-1930s, to the post-war era up to the independence wars of the 1960s and 1970s.

\subsection{The onset of colonial occupation, $1850 \mathrm{~s}-1910 \mathrm{~s}$}

The change from tribal rule to military occupation was violent, politically complicated and had remained far from completed at the start of the twentieth century. In Angola changing coalitions of African kings and chiefs supported and resisted colonial occupation. Earlier military campaigns during the sixteenth to ninenteenth centuries had never led to permanent occupation, but had influenced local expectations about Portuguese intentions. Especially the

\footnotetext{
${ }^{9}$ Attempts to introduce a land tax in 1868 failed in the metropole as well as the colonies (Cardoso and Lains 2010, p.263).
} 
Kingdom of Kongo, which tried to benefit from 'peaceful' trade in ivory and slaves with the Portuguese, and absorbed forms of 'cultural colonization', experienced frequent military confrontations in case it failed to meet Portuguese demands. Wheeler (1972, p. 68) has even claimed that "the traditional form of African resistance against Portuguese rule in Angola, was armed violence repeated on countless occasions over a period of 300 years".

These confrontations enhanced a type of micro-nationalist identity in the Kongo long before the emergence of the Angolan state. Kings of the Kongo were writing protest letters against Portuguese slave traders in the early seventeenth century, in order to protect their communities. In the mid-nineteenth century, this micro-nationalism triggered resistance against newly imposed taxes by the Portuguese. In 1841 Prince Alexus, brother of King Henry II of Kongo, ordered a major chief not to pay a new Portuguese tax in Dembos territory (Wheeler 1972, p. 68). The Dembo lived northeast of Luanda and were part of the Mbundu peoples, who consisted of an assembly of Bantu-speaking tribes in north-western Angola that were part of a paramount chiefdom. The Dembo were the last of the Mbundu tribes to be defeated by the Portuguese in a war that officially lasted for three years (1907-1910), but in reality the fighting continued up to 1917 . The conflict demanded considerable numbers of lives on both sides. Such violent resistance urged the colonial government to channel substantial resources into military campaigns, placing a large burden on the central budget, as I will show later on. However, after 'pacification' was attained and local chiefs were willing or forced to cooperate with the colonial administration, the existence of a semi-centralized political structure facilitated colonial control.

The colonial administration adopted a system of indirect rule in which privileges were provided to native chiefs who were loyal to the colonial administration and cooperated in local tax collection. Up to 1925, the armed forces of Angola consisted of a first-line army staffed by European soldiers and a larger second-line force of African auxiliary forces named as guerra preta (Wheeler 1969, p. 426). This system was supported by loyal sobas (chiefs) and its principal strength was its capability of rapid mobilization of African troops whenever a crisis broke out (ibid, p. 427).

The colonies were primarily supposed to provide the metropole with raw materials and markets for Portuguese exports. In 1898 a report of the Ministry of Marine and Overseas Affairs stated that "in countries, such as the Portuguese colonies, where the agriculture and industrial sectors are least developed, commercial movement is the best indicator of their economic progress" (Dias Costa 1898a, p.9). Infrastructural investments were key to encourage trade and local production (Dias Costa 1898a, p. 10). In reality, however, imperial 
trade consisted largely of re-exports of colonial produce to other European countries via Lisbon. This invited continuous manipulation of trade margins, and especially after the end of the liberal era in Portuguese politics. From a metropolitan viewpoint, these trade policies were successful. For most of the colonial era the African colonies contributed positively to Portugal's balance of payments and formed an important source of foreign currency for the Portuguese economy (Lains, 1998, p. 243).

Angola received the lion's share of private investments by agricultural, mineral and commercial corporations. It had been the main area for the trade in slaves, it held tracts of highly fertile soils and it had more developed markets for industrial goods from Portugal (Dias Costa 1898a, p. 56). Individual traders and white settlers (Portuguese, Greek, Lebanese) were also more active in Angola than in Mozambique. Yet, the colonial state in Mozambique benefitted from its proximity to the Rand mines in South Africa. This connection offered larger scope for a rapid expansion of public revenue through custom duties levied on cross-border trade, as well as direct taxes on circular migrant workers who went back and forth between Southern Mozambique and the Rand (Lains 1998, p. 254). Non-tax revenues from government controlled railways and ports also formed an important source of revenue. Because of the 'Rand effect' wage labour in Mozambique was more expensive than in Angola, and this may also explain a preference of private investors for Angola, especially in the labour-intensive plantation sector.

Portuguese inroads in the lower Zambezi region in central Mozambique followed a more gradual pattern, and resistance against conquest was broken earlier than in Angola. The defeat of the Gaza Kingdom in southern Mozambique in 1895 allowed the Portuguese to develop a fiscal administration, which was mainly run by concession companies. The use of private intermediaries had deep roots. From the sixteenth to the nineteenth century large land tracts had been granted by the Portuguese Crown to Portuguese merchants under the so-called prazo system. The prazeros were regarded as delegates of the Portuguese Crown and granted rights of feudal landlords as well as a major stake in local slave and ivory trades. The Zambezi chiefs (mambos) retained ownership over the lands cultivated by their peoples and preserved their judicial authority, a vivid example of legal pluralism. All the inhabitants within the chiefdom had to pay an annual tax in kind, called mutsonko (Isaacman 1972, p.26) to their chief, who supervised the tax collection at harvest time. The content of this tax varied from one area to another. The collected taxes were transferred to the prazero, who redistributed a percentage to the chief and his subordinates (ibid, p. 29, 31). Prazeros disposed of slave armies governed by achikundas, who policed indigenous farmers and controlled migration (ibid, pp. 
33-34). Few landlords could sustain their power without consent of indigenous leaders. Prazeros who bypassed a chief risked revolt (ibid, p.28) and in cases of abusive treatment, African chiefs sent petitions to the Portuguese government to explain their refusal to pay taxes (ibid, pp. 37, 39). ${ }^{10}$

In the mid-nineteenth century the prazo system went into decline due to the Ngoni invasions, the curtailing of the slave trade and due to new legislations such as the 1832 decree which reformed the land tenure system and ended the use of Zambezi as a penal settlement (Newitt 1969, pp. 79-80). From the 1840s, Portugal fought wars against the prazo families who tried to hold on to their 'traditional' privileges. The idea that prazo holders represented the interests of the Portuguese Crown had long evaporated. Through accumulation of wealth and intermarriages, prazo families had obtained a large degree of autonomy and a mixed race identity. By the end of the century, in 1895, the Portuguese army attained control over the central zone of Mozambique, with the support of British imperial troops. However, the prazos survived as fiscal agents up to the early $20^{\text {th }}$ century (ibid, p. 85).

By the 1890s, the control of the prazeros over central Mozambique had given way to large private concession companies such as the Companhia de Moçambique. In the period 1891- 1942, the Mozambique Company obtained a number of privileges, including the right to levy and collect taxes and manage the treasury of Manica and Sofala districts. Similarly, the Niassa Company ruled over the largest part of the northern zone of Mozambique from 1891 to 1929. During the 1930 s and 1940s these tasks passed on to colonial officials, who were appointed by the Portuguese government. As I will show below, these transfers of power had a notable effect on revenue and expenditure policies and practices. When the frontiers of the Portuguese African colonies were eventually demarcated, Lisbon shifted from a relatively free trade policy towards a "new colonial system", which aimed at maximizing trade revenues through stricter regulation (Lains 1998, p. 238).

\subsection{Colonial state revenue: sources and trends}

Clarence-Smith has argued that during the mid-nineteenth century, the Liberal party in Portugal regarded Angola as a potential source of public revenue to be invested in metropolitan

${ }^{10}$ Armed runaway slaves posed another threat to the stability of the prazos. In 1762, for instance, the governor of Mozambique stated that many prazeros abandoned their estates due to peasant revolts. 
infrastructure (1979, p. 167), in a similar way as the Dutch used surpluses from the East Indies to invest in canals, railways and to amortize part of their massive state debt. However, in this period, colonial state revenues never grew to extractable proportions and occasional deficits had to be covered by Lisbon via loans or subsidies. Especially in the 1880 s, when the military occupation started, transfers from Portugal to the colonies were substantial (Boletim Official de Moçambique 1889). Only from the 1910s onwards, the shares of Portugal's budget invested in the colonies declined, but were still ranging from $1 \%$ to $14 \%$ (the latter only in wartimes). In the 1960s, Portugal again allocated higher shares of its resources to the colonies (Ferreira and Pedra 1988).

Lains has argued that, on the whole, Portugal did not have to spend excessive sums to retain her colonies, and that the trade benefits through price and exchange rate controls largely outweighed these investments (1998, p. 241). Based on data from Mata (1993) he concluded that metropolitan expenditures on the colonies remained below 5 per cent of annual total expenditures for most of the 120 years between the 1850s and 1970s. Metropolitan expenditures only spiked during the military campaigns of the 1890s, the First World War and the independence wars, and particularly in the case of Angola. Up to WWI the share of colonial spending in the metropolitan budget reached about 12\% (Lains 1998, p. 249). That said, 5 per cent of annual expenditures is far more than the 0.29 per cent that Huillery (2014) has calculated for France pouring into French West Africa (see also chapter 4).

Throughout the nineteenth century, the single most important source of public revenue, for both Portugal as well as the emerging colonial administrations in Africa, consisted of the alfandegas, the custom houses. Import and export taxes were imposed in 1838 (Repartição Superior de Fazenda 1908, p.15) and accounted for roughly two-thirds of total revenue (Monteiro 1941, p. 46). In the recession years of the 1890s, preferential tariffs were promulgated, favouring the shipment of colonial commodities via Lisbon (Clarence-Smith 1985 , pp.85-86). By the early $20^{\text {th }}$ century, the African colonies accounted for c. $15 \%$ of total Portuguese exports (Lains 1998, p. 239). Yet, the predominance of custom duties in the revenue mix changed after the occupation of the interior regions in Mozambique, as figure 2.1 demonstrates. Figure 2.2 shows that direct taxes also gained ground in Angola, especially after World War One. The rise of non-tax revenues was mainly driven by railway revenues. 
Figure 2.1: Real tax and non-tax revenue in Mozambique, 1850s-1970s

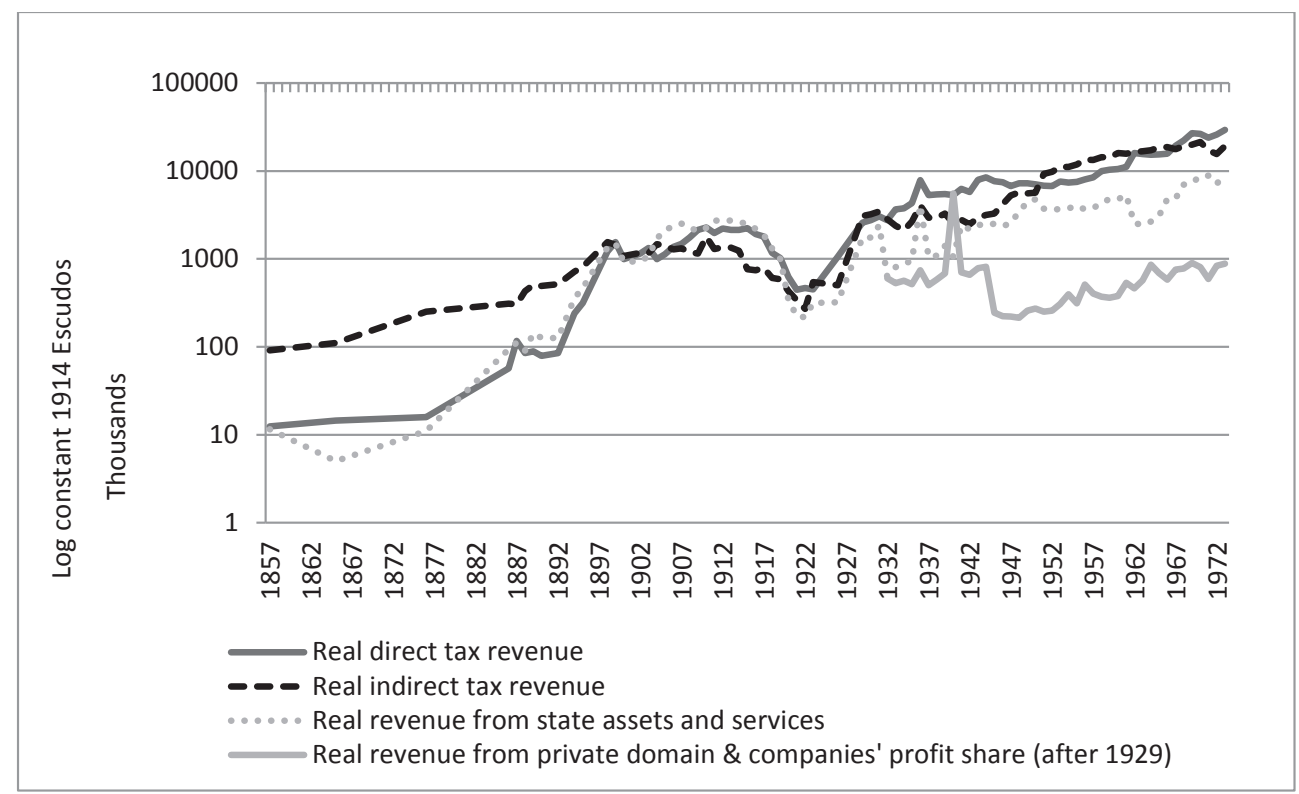

Source: Boletim Official, Orçamentos Gerais (General Budgets) and Anuários Estatísticos (Statistical Yearbooks) of Mozambique and Angola, various issues between 1857 and 1973.

Notes: For the figures referring to the early colonial period or the whole colonial era, I used the consumer price indexes (CPI) constructed by Valério and Tjipilica (2008) especially for Mozambique and Angola, with 1939 and 1914 as base years respectively and extrapolated them, based on the CPI constructed by Valério (2001) for Portugal. I deflated all past currencies used by the two colonies for the respective periods: Real (1430-1911), Mozambican Escudo (1914-1980), Angolan Escudo (19141928, 1958-1977) and Angolar (1928-1958). Both the Mozambican and the Angolan Escudo were almost equivalent to Portuguese Escudo (1911-1999). In the case of Reis (1 Escudo=1000 Reis) and Angolares (1 Angolar=1,25 Escudos), I first converted them to Escudos before deflating them. For the figures referring only to the late colonial period, I used the extrapolated wholesale price index (WPI) based on data provided by Mitchell (2008), with 1954 as base year. 
Figure 2.2: Real tax and non-tax revenue in Angola, 1850s-1970s

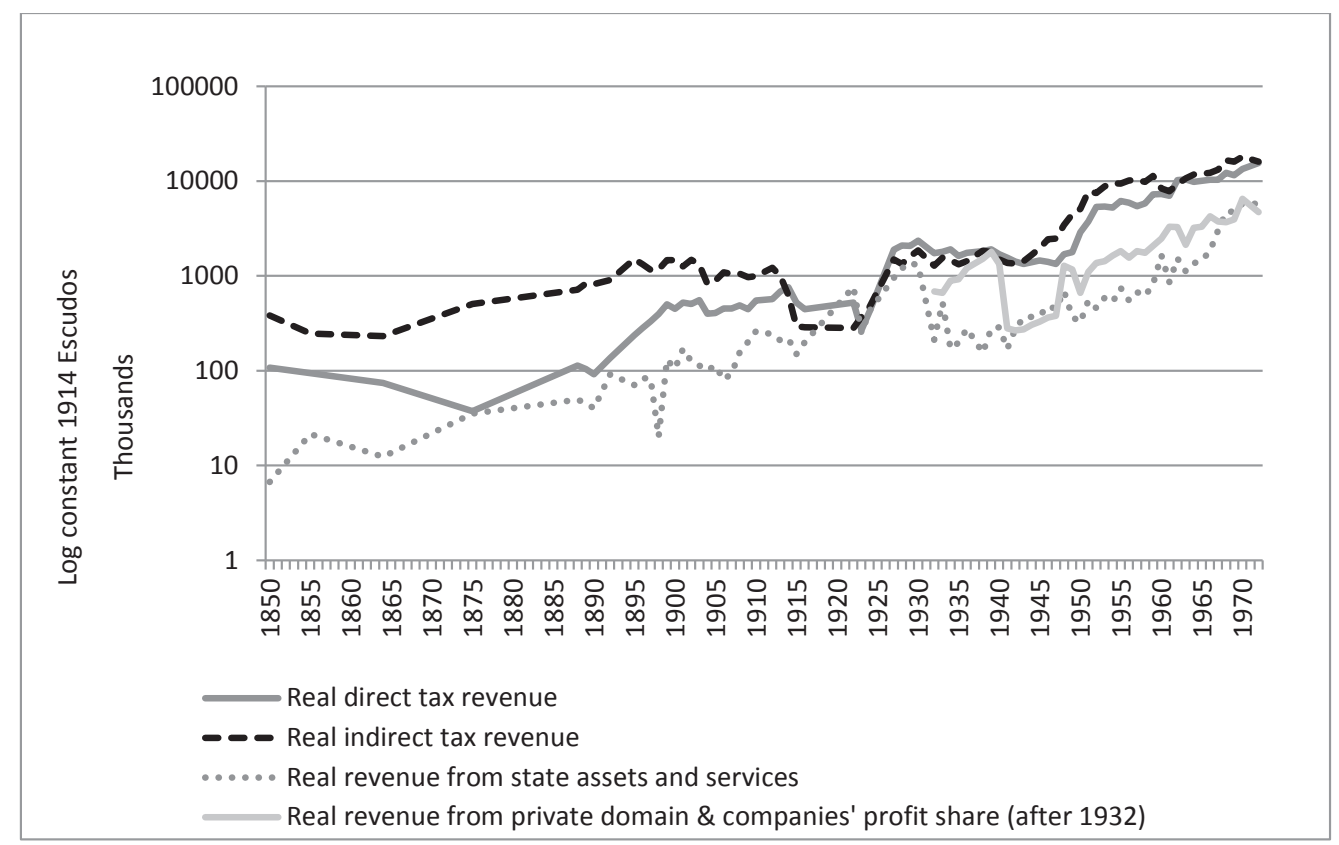

Sources: Boletim Official, Orçamentos Gerais (General Budgets) and Anuários Estatísticos (Statistical Yearbooks) of Mozambique and Angola, various issues between 1850 and 1972; for the conversion of nominal into real revenues see notes below Figure 2.1

Throughout the colonial era, Angola's state budget relied more on trade taxes. As figures 2.3 and 2.4 show, in the 1930 s to 1970 s, the contribution of export taxes was almost equal to the contribution of import taxes in Angola, whereas in Mozambique export taxes remained quite small and the gap with import taxes kept growing, especially after 1945. Angola's export sector expanded impressively after 1945 and ad valorem taxes on principal export commodities such as coffee, sugar, cotton and sisal was a significant revenue source for the Angolan colonial government (see Appendix Figures A2.1 and A2.2). Moreover, whereas Mozambique was a net food importer, Angola was a net food exporter (Kyle 1999, p.2). In Mozambique the ports of Lourenço Marques and Beira functioned as transit ports for import goods destined for South Africa and Southern Rhodesia respectively, while domestic export revenues remained low (Frankel 1938, p. 368-69). In view of this transit function, imports were arguably a more effective fiscal target. 
Figure 2.3: Import and export taxes in Mozambique, 1930s-1970s

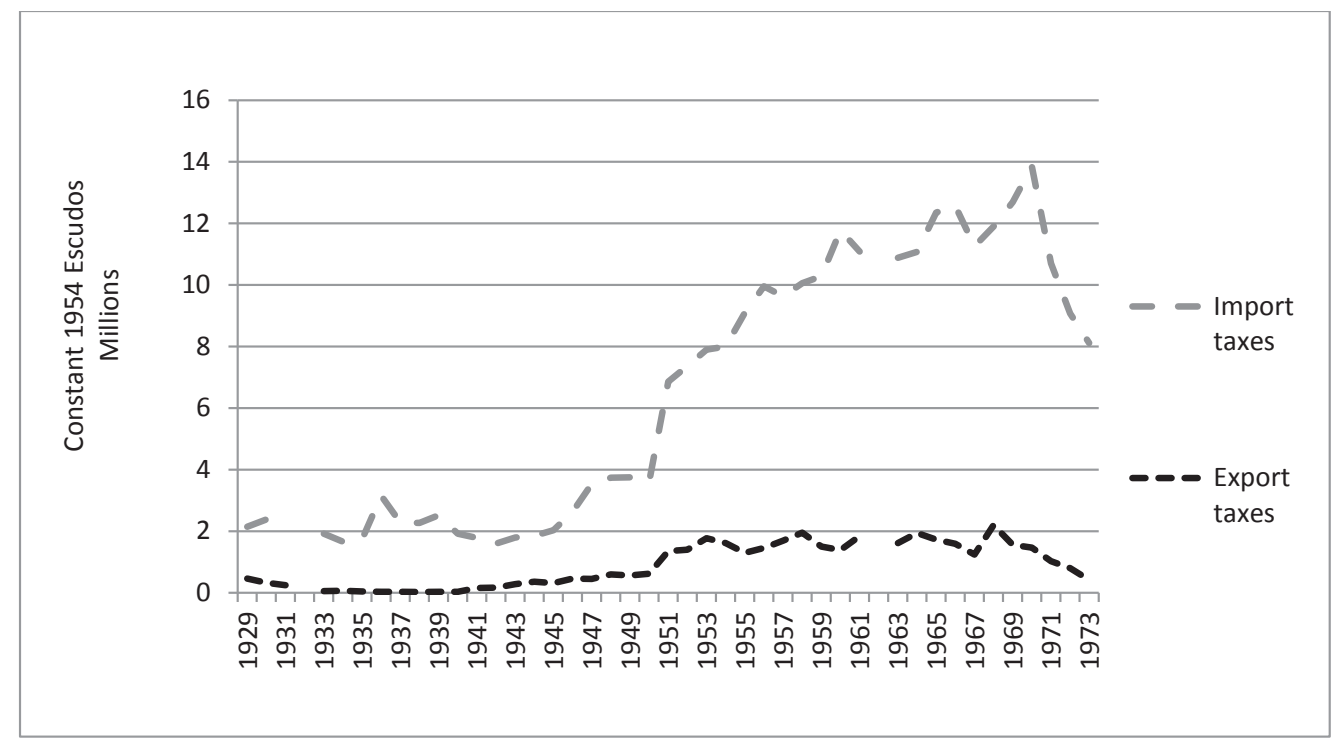

Source: Anuários Estatísticos (Statistical yearbooks) and Contas de Gerência (Accounts) of Mozambique, various issues 1929-1973; Price deflator: WPI from Mitchell (2008), Table H1.

Figure 2.4: Import and export taxes in Angola, 1930s-1970s

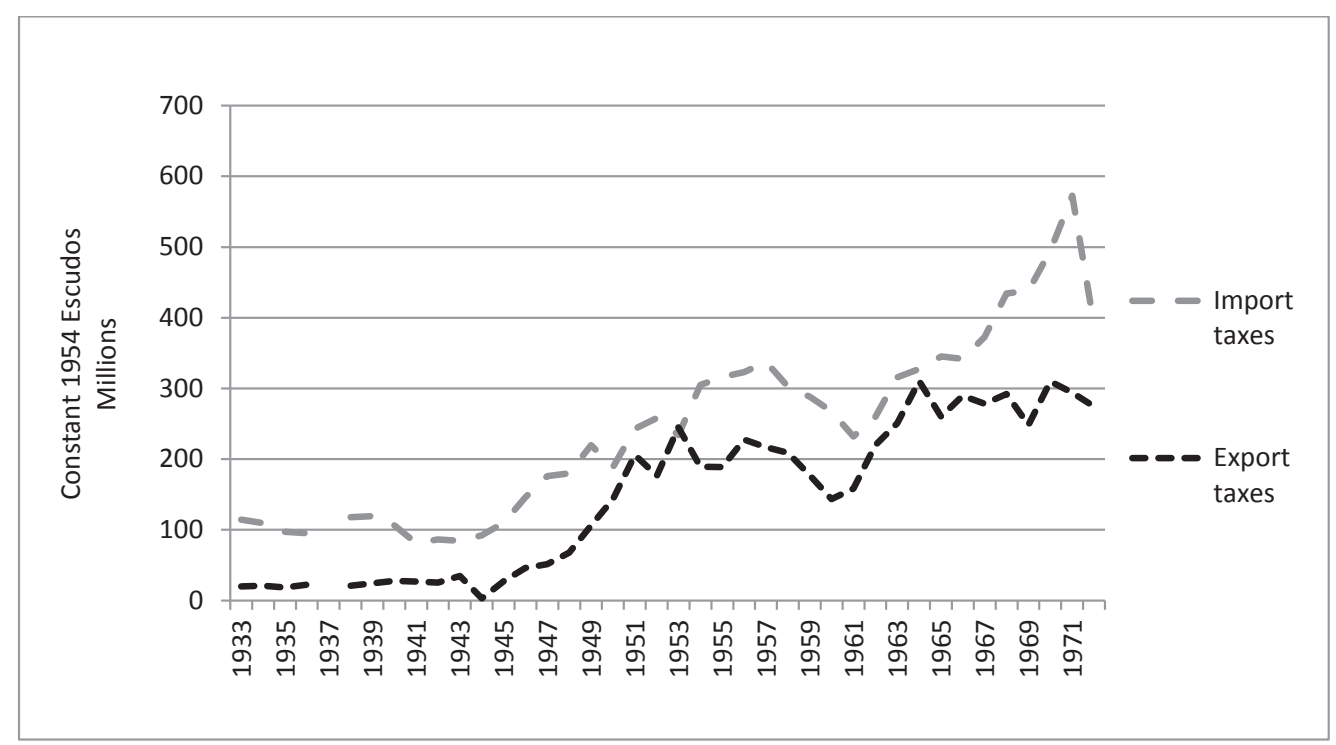

Source: Anuários Estatísticos (Statistical yearbooks) and Contas de Gerência (Accounts) of Angola, various issues 1933-1973; Price deflator: WPI from Mitchell (2008), Table H1. 
However, one of Angola's most significant export products, diamonds, remained untaxed. The Companhia de Diamantes de Angola (Diamang) engaged in mining activities in colonial Angola from 1917 until independence in $1975^{11}$. The 1921 agreement between the Portuguese state of Angola and Diamang "called for the company to grant to the colony $40 \%$ of its net profits, 100,000 shares of Diamang stock, and a series of loans at very favourable repayment rates. Moreover, the pact formally exempted Diamang from all current and future tax obligations on profits, imports, and all of its diamond exports - an arrangement not even enjoyed by missionaries operating in the colony" (Varanda and Cleveland 2014).

The direct taxes that emerged with the expansion of the colonial state consisted of three main sources. First, the indigenous population paid a hut or head tax and labour migrants in Mozambique also paid a migration tax. ${ }^{12}$ These direct taxes on 'indigenous' Africans formed the bulk of direct tax revenue. Second, enterprises and individual entrepreneurs (white settlers) operating in the colonies paid a corporate income tax, also named as 'industrial tax' (contribuição industrial). Third, there was a property tax (contribuição predial) levied on urban and rural real estate (especially buildings or land in urban zones), exempting state assets, church property and residencies of indigenous people. ${ }^{13}$ Especially in Angola, the capacity of the concession companies to collect these taxes and manage the fazendas (treasuries) was limited. Contrary to the chartered companies in Mozambique, the Companhia de Mossamedes operating in the southern part of Angola did not obtain the right to levy custom duties, nor to tax local Africans. Only in 1923, when the colonial state had secured control over this area, their charter was abolished (Clarence-Smith 1979, p.173, 177). In 1928 both the metropolitan and the colonial governments introduced a progressive tax (imposto de salvação pública) on the income of civil servants (Havik 2013, p.168). However, it remained of minor importance.

The dizimos - after 1883 the hut tax (imposto de palhota) - were annual taxes imposed on indigenous households at fixed rates (Repartição Superior de Fazenda 1908, p. 13). Colonial fiscal policies followed the trends in Portugal, where the government failed to foster a modern direct tax system and higher-income classes achieved exemption from income tax that was introduced in 1880 (Cardoso and Lains 2010, p. 263). In the 1910s to 1930s the rate was set at 2.5 Escudos to be paid by Africans who "squatted' on settler farms. The 'squatters' were forced

\footnotetext{
${ }^{11}$ After the independence, in 1977, Diamang was nationalised and in 1988 it was officially dissolved.

${ }^{12}$ For reasons unclear to me, over the early colonial era these migration taxes were recorded in the broad category of proprios nacionais in the Portuguese records (Repartição Superior de Fazenda 1908, p.21).

13 The same direct taxes were introduced in Portugal by early 1840s. Décima tax was replaced by three separate taxes on property, production and personal income (Cardoso and Lains 2010, p.261).
} 
to either pay the tax and become tenants, or to move into one of the native reserves, where the soils were poorer (Direito 2013a, p. 365). By 1918 the hut tax was renamed as "indigenous tax" (imposto indigena), and had to be paid by all African adult men. It became the most important revenue source for the colonial state of Mozambique. ${ }^{14}$ According to the 1946 legislation on the indigenous tax, $30 \%$ of the collected revenue had to be spent on indigenous affairs (sanitation and agriculture assistance) of which $20 \%$ was managed by the municipalities (Colónia de Mocambique 1946). After the end of the indigenato system (the informal colour bar) in 1958, this tax was renamed as personal tax (taxa pessoal). ${ }^{15}$

Table 2.1: Direct tax revenue in Mozambique, 1920-1960

\begin{tabular}{|c|c|c|c|c|c|c|c|c|c|c|}
\hline & \multicolumn{2}{|c|}{1920} & \multicolumn{2}{|c|}{1930} & \multicolumn{2}{|c|}{1940} & \multicolumn{2}{|c|}{1950} & \multicolumn{2}{|c|}{1960} \\
\hline & $\begin{array}{l}\text { Escudos } \\
(\mathrm{x} 1000)\end{array}$ & $\%$ & $\begin{array}{l}\text { Escudos } \\
(\mathrm{x} 1000)\end{array}$ & $\%$ & $\begin{array}{l}\text { Escudos } \\
(\mathrm{x} 1000)\end{array}$ & $\%$ & $\begin{array}{l}\text { Escudos } \\
(\mathrm{x} 1000)\end{array}$ & $\%$ & $\begin{array}{l}\text { Escudos } \\
(\mathrm{x} 1000)\end{array}$ & $\%$ \\
\hline Property tax & 110 & 3 & 3,580 & 6 & 6,310 & 5 & 15,492 & 6 & 24,645 & 6 \\
\hline Indigenous tax & 2,400 & 66 & 39,630 & 64 & 110,000 & 85 & 205,681 & 77 & 342,540 & 80 \\
\hline $\begin{array}{l}\text { Corporate tax } \\
\text { Other direct }\end{array}$ & 194 & 5 & 8,681 & 14 & 12,988 & 10 & 30,186 & 11 & 48,864 & 11 \\
\hline taxes & 911 & 25 & 9,923 & 16 & .. &.. & 14,540 & 5 & 10,883 & 3 \\
\hline $\begin{array}{l}\text { Total direct } \\
\text { taxes }\end{array}$ & 3,615 & 100 & 61,814 & 100 & 129,298 & 100 & 265,899 & 100 & 426,932 & 100 \\
\hline
\end{tabular}

Source: Anuários Estatísticos (Statistical yearbooks) and Contas de Gerência (Accounts) of Mozambique, various issues 1920-1960.

\footnotetext{
${ }^{14}$ In the years 1901-1908 the total "peasant tax" (imposto campones) constituted only $13 \%$ of the total revenue of the overseas provinces Mozambique, Angola and Guinea. The peasant tax results from the hut tax and the property tax, plus the license tax for the plantation of palm and cashew trees (Santos 2015, p.52).

${ }^{15}$ From the 1920s to 1950s Mozambique was characterised by a dual system of colonial governance. As Mamdani points out, the so-called Indigenato subordinated Mozambican subjects to tribal chiefs and Portuguese citizens to colonial administrators (O' Laughlin 2000, p.16). The code of the Indigenato was formally adopted in 1928 and it concerned principally labour relations (O' Laughlin 2000, p.12), but it was based on previous perennial arrangements of citizenship and governance. As in parts of British Africa, it aimed at legitimising the new system of governance by drawing in existing political structures. Regulos and cabos were responsible for hut tax collection, land distribution and forced labour recruitment and were paid by the colonial state through commissions (ibid, p.17). Although there was some space for negotiations between local African leaders and colonial officials, in tax affairs the chiefs were mainly used as instruments by the colonial state.
} 
Table 2.2: Direct tax revenue in Angola, 1920-1960

\begin{tabular}{|c|c|c|c|c|c|c|c|c|c|c|}
\hline & \multicolumn{2}{|c|}{1920} & \multicolumn{2}{|l|}{1930} & \multicolumn{2}{|l|}{1940} & \multicolumn{2}{|c|}{1950} & \multicolumn{2}{|c|}{1960} \\
\hline & $\begin{array}{l}\text { Escudos } \\
(\mathrm{x} 1000)\end{array}$ & $\%$ & $\begin{array}{l}\text { Angolares } \\
(\mathrm{x} 1000)\end{array}$ & $\%$ & $\begin{array}{l}\text { Angolares } \\
(\mathrm{x} 1000)\end{array}$ & $\%$ & $\begin{array}{l}\text { Angolares } \\
(\mathrm{x} 1000)\end{array}$ & $\%$ & $\begin{array}{l}\text { Escudos } \\
\text { (x1000) }\end{array}$ & $\%$ \\
\hline $\begin{array}{l}\text { Property tax } \\
\text { Indigenous }\end{array}$ & 550 & 8 & 1,740 & 3 & 3,074 & 5 & 4,439 & 2 & 20,581 & 5 \\
\hline $\begin{array}{l}\text { tax } \\
\text { Corporate }\end{array}$ & 6,000 & 86 & 51,000 & 89 & 45,169 & 71 & 88,744 & 46 & 120,733 & 32 \\
\hline $\begin{array}{l}\text { tax } \\
\text { Other direct }\end{array}$ & 315 & 5 & 4,782 & 8 & 10,686 & 17 & 42,603 & 22 & 97,949 & 26 \\
\hline taxes & 135 & 2 & .. & .. & 5,053 & 8 & 58,427 & 30 & 139,725 & 37 \\
\hline $\begin{array}{l}\text { Total direct } \\
\text { taxes }\end{array}$ & 7,000 & 100 & 57,522 & 100 & 63,982 & 100 & 194,213 & 100 & 378,988 & 100 \\
\hline
\end{tabular}

Source: Anuários Estatísticos (Statistical yearbooks) and Contas de Gerência (Accounts) of Angola, various issues 1920-1960.

In Angola, the pressure to implement direct taxes was arguably lower, and the constraints were higher given the lack of a pre-existing network of settlers or planters that could aid tax collection. The so-called tributos were collected by tribal chiefs, while the dizimos were collected by the colonial government. The latter was a fixed annual tax on each household and on each unit of cattle the household owned, plus a percentage of the value of its crop production and of its property income each year. There is evidence showing that in the late nineteenth century poor indigenous families used to burn their houses and leave their villages in order to avoid paying the dizimos (Governo Geral de Angola 1920, p.7). In 1888 this tax was replaced by the hut tax (imposto sobre cubatas), which was reformed in 1907 (Melo 1953, p. 72). The hut tax had to be paid by the headmen of all indigenous families (Legislação administrativa 1918, p.27).

In 1919 the hut tax was renamed as a head tax (imposto de capitação) and in 1920 as indigenous tax (imposto indigena) which, according to legislation of 1931, could only be paid in money and no longer in kind (Melo, 1953, p.72). In 1920 the individual tax in Angola was set at 2 Escudos and concerned the black and mixed race residents. As high as $70 \%$ of the collected revenue had to be reserved at the national treasury, to be redistributed by the state, and only $10 \%$ out of the remaining $30 \%$ could be spent by the municipalities on public assistance (Governo Geral de Angola, 1920, p.14-15). In 1949 the indigenous tax was replaced 
by the personal annual tax (taxa pessoal anual) levied on all "black, non-civilized" adult male, who didn't contribute through other types of taxation (Melo 1953, p.73). After 1950 the revenue derived from the corporate income tax caught up quickly with the indigenous tax revenue. The corporate tax was paid by individual entrepreneurs or businesses involved in trade, construction, food and arts. State companies, service companies and the naval industry were exempted (Angola Repartição Técnica de Estatística Geral 1954, p. 3).

From the evidence presented above, I draw the conclusion that that the management of tax revenue in Angola was more centralized than in Mozambique, where concession and private companies as well as municipalities played a more important role. The organization of direct taxes differed between Mozambique and Angola in another respect. Whereas in Angola the system was eventually enrolled on a 'national' level, in Mozambique the system never attained uniformity in geographic terms. Alexopoulou and Juif (2017) have shown that in Mozambique different systems operated in the north, the center and the south of the country, which were closely related to different systems of agricultural production (Bowen 2000, p. 32) and labour recruitment. Figure 2.5 shows the contribution of the three zones to direct tax revenue in the 1930 s to 1970 s.

The north (Cabo Delgado, Niassa and Nampula provinces) consisted of a rather poor indigenous peasant economy which received a tiny share of public funds. In the years 18911929, the British-controlled Niassa Company was active in the region, but it was forced to give up its operations during the depression of the early 1930s. The central zone (Zambezia, Manica, Sofala and Tete provinces) included an expanding plantation economy, producing export crops such as sugar and sisal. These plantations were also largely run by the Britishcontrolled Companhia de Moçambique and the British-owned Companhia de Zambezia (Paton 1994, p.140). The Company of Mozambique had obtained the exclusive right to collect taxes, while the company itself enjoyed a 25-year tax exemption (Isaacman and Isaacman 1983). The so-called Guarda fiscal, a branch of the public police/military force, was authorized to inspect the collection of custom duties in the territory of the Mozambique Company (Dias Costa $1898 \mathrm{~b})^{16}$. Both the colonial administration and the companies forced indigenous people to work on plantations or infrastructural projects. The hut tax was not only used as a means to raise revenue, it was also used to force labour into the export sector. The southern zone (Inhambane, Gaza and Maputo provinces) was dominated by private settler farms, rather than

\footnotetext{
${ }^{16}$ There were no duties on overland domestic trade (also because of the lack of an adequate bureaucratic machine), so Guarda fiscal was principally concerned with the custom duties that were collected on the port of Beira in the account of the Company.
} 
concession companies, and developed into the major sending area of migrant workers into the mines of South Africa. While the south had the fiscal features of a typical 'labour reserve economy' dominated by direct taxes, the centre relied much more on trade taxes, despite the gradual increase of indigenous tax revenue. Although the colonial state of Mozambique increased its military and administrative control across these three zones, the existing, differentiated patterns of taxation were largely kept in-tact (Alexopoulou and Juif, 2017).

Figure 2.5: Real direct tax revenue per capita and per zone in Mozambique, 1930s1970s

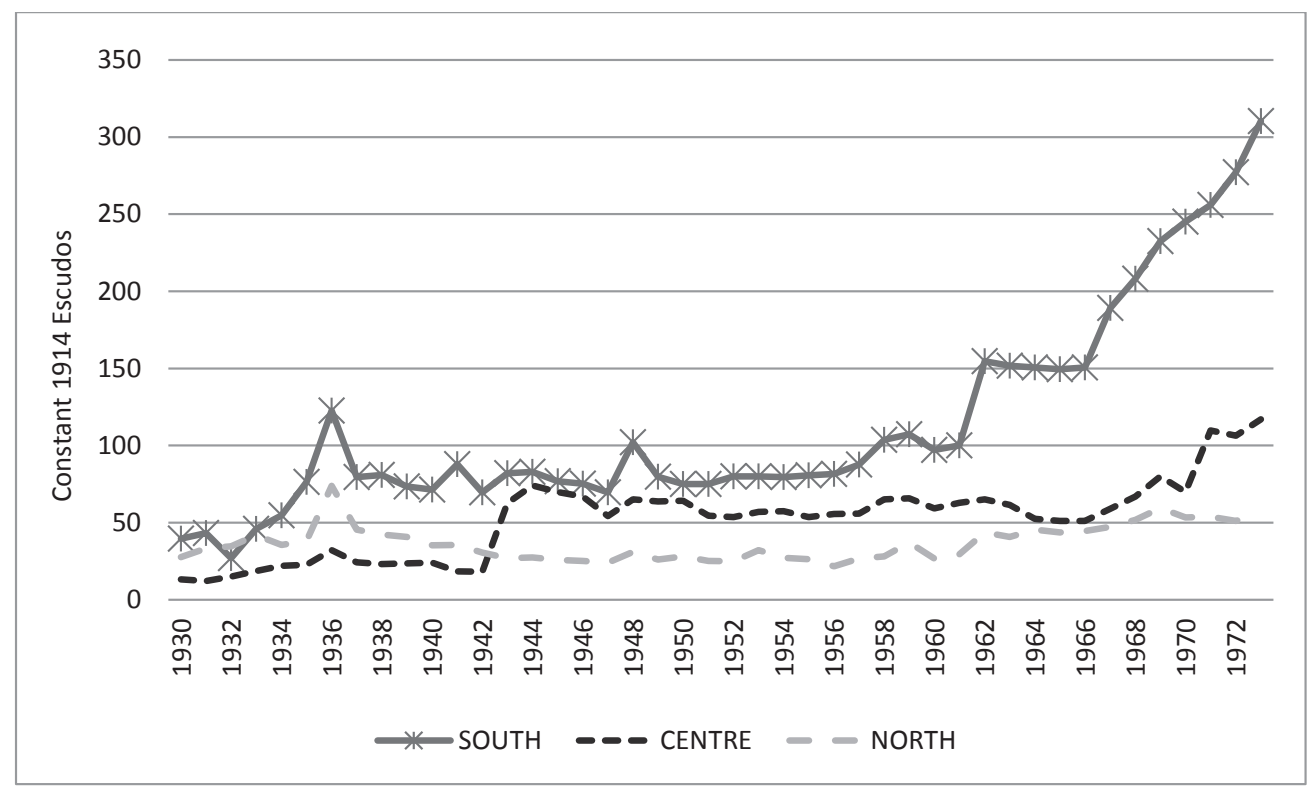

Sources: Contas de Gerência (Accounts of Mozambique); Population estimates from Frankema and Jerven (2014); price deflator: Valério (2001), Table 8.1.

The persistence of this divergence was caused by two factors. First, the rise in wage labour migration from southern Mozambique to the South African mines enabled the state command higher direct taxes. Second, the increase of imperial subsidies to the Portuguese settlements from the 1930s (O' Laughlin, 2000, p.10) and the migration boom from Portugal in the 1940s (Castelo 2007) strengthened the settler farm economy in the southern zone. As a result, this zone became more competitive in terms of production and trade and thus generated more revenue from indirect taxes. In the other two zones, and particularly in the north, the 
concessions ended and forced cotton cultivation was introduced by the colonial state and smaller private companies. This shift in colonial policy intensified the dynamics that were already in place, instead of reversing them.

From the 1870 s to the 1900 s the direct taxes levied on Africans in the 'pacified' parts of Angola could be paid either in kind or in money (Castro 1948, pp.37-38). In the Regulation on registration and collection of indigenous tax these taxes were described as "a valuable element of politics for the affirmation of Portuguese sovereignty, and a practical means of collecting subsidies for the organization of provincial censuses" (Governo Geral de Angola, 1920 , p. 5). It took long before this system was entirely monetized, but the arguments for direct taxation were similar to those used in other African colonies (see Bush and Maltby 2004, Gardner 2012).

In the 1890 s, the regional commissioner of Mozambique, Antonio Enes, had linked the ideas of fiscal monetization to the enhancement of forced and voluntary wage labour schemes in order to stimulate agricultural development and expand "civilization" (Ferreirinha 1947, p. 5). In the early twentieth century the governor of Lourenço Marques (Mozambique) complained about the transportation and storage costs related to in-kind taxes as well as price fluctuations of crops and also argued that endemic labour scarcity could be lifted by monetary taxes, which would stimulate the growth of a wage labour market (Aguiar n.d., pp. 75-76).

\subsection{Regime changes in Portugal and the dogma of fiscal balance}

So far, I have focused attention on how local conditions, and especially the contested process of colonial occupation, shaped the revenue side of the fiscal systems that emerged in Angola and Mozambique. In this section, I will highlight the impact of political changes in the metropole, especially with regard to some major reforms of imperial finances in the 1910s to 1930s.

In 1910 the Republican revolution toppled the Portuguese Monarchy. The republican era was characterized by a more liberal view on colonial rule, and included the adoption of the so-called "decentralization" policy, which was comparable to the idea of fiscal selfsufficiency that Britain promoted in colonial Africa (De Oliveira Marques 2001, p. 22). The African "provinces" - a term introduced under the monarchy - had to gain autonomy in administrative and financial terms and the Leis Organicas adopted in 1914 and the Cartas Organicas of 1917 arranged the legal dimension of this autonomy: the Portuguese colonies 
obtained their own police, military and marine forces as well as transportation services (Vasconselos 1920, p. 179). Moreover, the capacity of the colonies to borrow from metropolitan and international credit markets and serve their public debt (divida) was one of the arguments for their autonomy (Costa 1903, pp.155-156 in: Santos 2015, p. 39). Law 278 of 1914 made Caixa Geral de Depósitos (Portugal's largest public sector banking corporation established in Lisbon in 1876) the preferential creditor of colonial governments. ${ }^{17}$ The reasons for decentralization may have been ideological as well as pragmatic. Since colonial budget deficits had grown substantially during the occupation efforts up to 1910, greater autonomy also meant a stricter separation between Portuguese and African tax-payers.

The Republicans aimed to strike a balance between the British system of indirect rule and the French system of direct rule, by giving administrative and fiscal autonomy to the colonial state and African chiefs (who were involved in tax collection), while on the other hand pursuing an assimilationist agenda promoting the "civilization" of natives through civil law, and by constraining the influence of the clerical missions. In practice, the financial autonomy of the colonies from 1914 implied limited transfers from Lisbon, increasing direct taxation as well as contracting loans on the international market and accumulating debt (Havik 2013, pp.178-179). Decentralization did not help much to keep imperial finances under control. The military investments incurred during the First World War and the ensuing post-war hyperinflation depleted colonial state budgets too. In the 1920s the financial crisis in Angola led to the replacement of the Banco Nacional Ultramarino ${ }^{18}$ by the Bank of Angola as an issuing bank of the Angolan Escudo, named Angolar, which was devalued against the Portuguese Escudo in 1928 (Valério 2002, p. 4).

Figure 2.6 shows that the interest payments on Angolan government debt exploded after the appointment of Norton de Matos as High Commissioner of the Republic (1921-1923). ${ }^{19}$ However, from an international perspective it was not uncommon to spend $15 \%$ of the state budget on debt service. Most of the loans were provided by Lisbon and were used to finance investments in infrastructure. In contrast to Angola, the government of Mozambique struggled

\footnotetext{
${ }^{17}$ This is based on internal email correspondence with Prof. Nuno Valério and I thank him for his insights into certain issues.

${ }^{18} \mathrm{BNU}$ was created in 1864 as a step towards the building of a coherent economic space, based on the French model of colonial banks. BNU enjoyed the monopoly of banknote issuing in the whole Empire and until 1901 enjoyed also the monopoly over banking activities (Valério 2002, p.4).

${ }^{19}$ De Matos became high Commissioner after having served as General Governor of Angola (1912$1915)$ and as Minister of War (1915-1917). In the 1940s he became a leading opposition figure against the Salazar regime.
} 
to obtain international loans. According to Vail and White (1978), South Africa did much to block such loans in order to retain the migration flows of Mozambican workers to the South African gold mines. For example, in 1922, when it was rumoured that J. P. Hornung, the head of Sena Sugar Estates Ltd., was negotiating a loan of 5 million pounds for Mozambique, General Smuts, prime minister of the Union of South Africa, put pressure on 'American capital' in Whitehall and succeeded in having the loan blocked. After the overthrow of the Republicans in 1926 by a coup d'état, Portugal attempted to raise a loan of 12 million pounds from private banks and the League of Nations. The South African government argued that such a loan should be blocked "because it would fund development projects undertaken by forced labour" (Vail and White 1978, p. 242).

Figure 2.6: Shares of debt service in total expenditure of Angola and Mozambique, $1920 \mathrm{~s}-70 \mathrm{~s}$

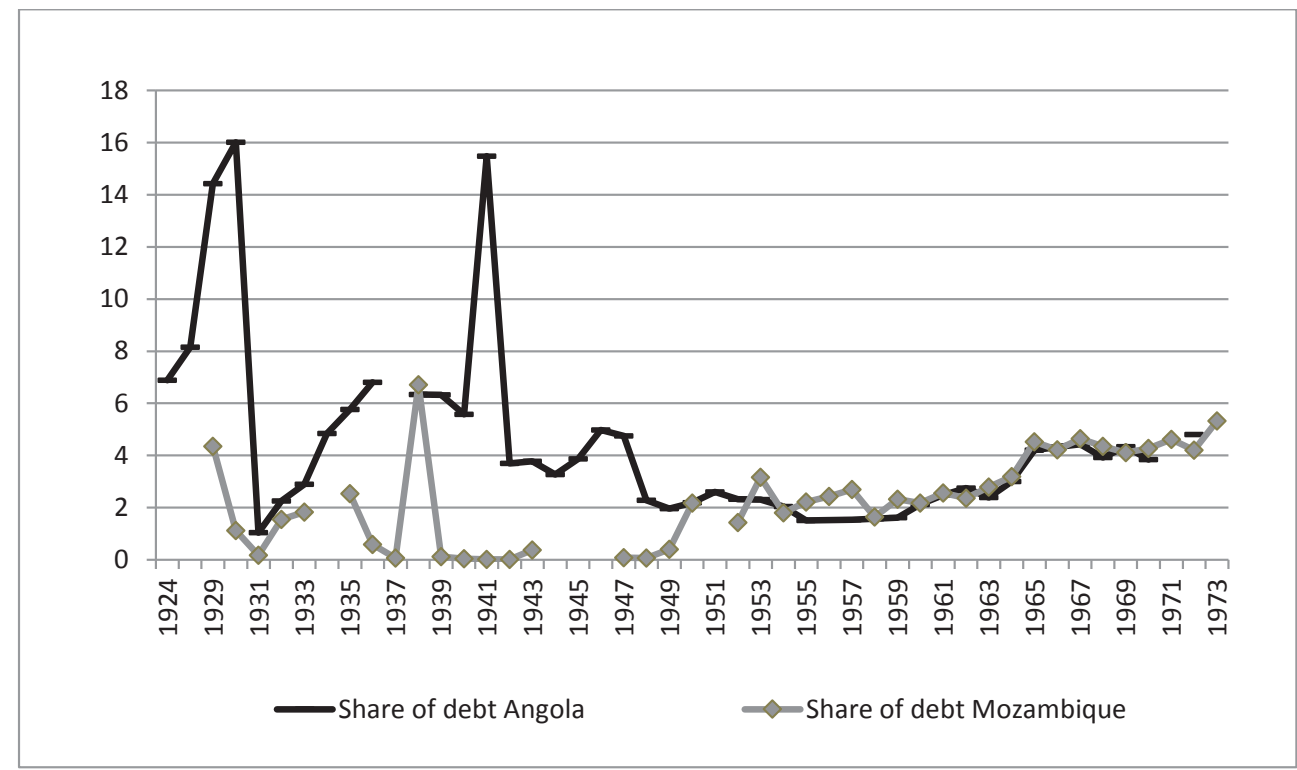

Source: Orçamentos gerais (Budgets) and Contas de Gerência (Accounts) of Angola and Mozambique; price deflator: Valério (2001), Table 8.1.

Decentralization policies were halted after the military coup of 1926 and the establishment of Salazar's Estado Novo in 1933 (De Oliveira Marques 2001, p.23). In the midst of the great depression, Salazar strived to re-unify the empire and obtain a stricter control 
over imperial finances, including the imposition of austerity measures and social repression (e.g. forced cultivation) in order to curb colonial deficits. The Portuguese Ministry of the Colonies had to approve the general budgets of all colonies every year. The main financial principle of the "New State" was the so-called politica de equilibrio orçamental, the policy of balanced budgets (Conceição 1967, p.3). Monetary flows were strictly controlled (Lains 1998, p. 251). Colonial policies had to be in line with the national interests of Portugal and the Lisbon government was regarded as the principle authority. The 1930 Colonial Act created a juridical and political union that was supposed to harmonize the economic interests of the colonies and the metropole (Antologia Colonial Portuguesa, 1946, p. 331-332). Ironically, Salazar himself extensively used the term "self-sufficiency" (autosuficiencia), but for him it referred to the sufficiency of the Portuguese Empire as a whole, as a united economic system.

From 1931 onwards, Salazar carried out a re-centralization program in order to redress the putative administrative "chaos" and financial deficits caused by the Republicans. In 1932 a new corporate income tax was levied on private and state-run companies. In Mozambique the contribution remained negligible, but in Angola it gained some importance. In theory, the Salazar regime promoted a "minimalist" state, with low taxes and minimal expenses. Salazar denied any financial aid to Angola and propagated stability over growth in the overseas territories. Colonial officials in key positions were reshuffled (Smith 1974, p. 663). In practice, however, direct tax revenues increased right from the beginning of Salazar's governance, while public investments remained low until the 1940s. "No matter how pressing their needs, areas such as rural development, the health services and education would have to wait until the necessary surplus was in hand" (ibid, p. 662).

With the exception of wartime expenditure in the early 1940s, the New State retained the debt position of both colonies at very low levels. The colonial records of both countries demonstrate an almost absolute equation of revenue and expenditure (see Appendix Figures A2.3 and A2.4). It is difficult to assess, whether these records fully represent fiscal reality, and to what extent these were artificial "constructions" of colonial governments that needed to abide by metropolitan directives. What seems clear, however, is that the capacity of the colonial states of Angola and Mozambique to invest in welfare services was severely constrained. Exports and re-exports via the metropole were stimulated so that "the colonies were often well supplied with unnecessary commodities from Portugal, while starving for essentials which could only be obtained from elsewhere" (Smith 1974, p. 666).

In 1949 new tax reforms in Angola were adopted to further raise the contribution of direct taxes, especially income taxes. The reforms were propagated as a policy to enhance 
wealth and income redistribution (Conceição 1967, p. 10-11). However, the idea that direct taxation would contribute to social justice more than indirect taxation was inspired by the Western fiscal regimes, where income and property taxes were increasingly made progressive. In Portuguese Africa, the main form of direct taxation, the hut/poll tax, was uniformly applied to indigenous adult males at fixed rates, regardless of their income. Havik stresses that the actual sum of taxes paid by heads of households was notably greater than the monetary value of the huts (2013, p.185).

As Vail and White (1983) have shown, in Mozambique the indigenes expressed their resistance against the Portuguese rule and rising taxes also in indirect ways, for example via singing songs such as the Katini's ngodo of 1940: "It is time to pay taxes to the Portuguese/The Portuguese who eats eggs /And chicken/ Change that English pound!” (Tracey 1970). There is evidence showing that tax rates were regionally differentiated, especially in the case of Mozambique (Inspecção superior dos negocios indígenas 1951). For instance, in northern Mozambique the tax rates were lower. The colonial state attempted to broaden the tax base by obliging women to pay taxes, but revolts broke out (ibid, p.186). Property taxes always formed a minor source, and included a fixed and progressive rate from 1940 onwards. Only in the 1960s a new tax was levied on white settlers (imposto profissional).

To further centralize revenue collection and promote tight treasury management, Salazar removed the fiscal powers from the chartered companies. The concessions in the central zone of Mozambique were terminated in 1942. The private leasing companies, which operated plantations using forced labour, were no longer allowed to keep the money they collected from the hut tax "in exchange for an annual rental fee paid to the government" (Smith 1974, p. 664). The charter of Niassa Company in the north was already terminated in 1929 and the government obtained authority for the collection of taxes, while the Banco Nacional Ultramarino was converted into a partner of the state (Smith, 1974, p. 665). Only the "Diamang Company" in Angola retained the concession for diamond mining from 1917 until independence. However, Diamang did not obtain any parastatal or political rights within its concession area, where the state always maintained the authority to collect taxes. In this sense, the Diamang monopoly over the mining of and trade in diamonds was consistent with Salazar's policy to end the concessions to private companies. ${ }^{20}$ Smith is clear on the two main legacies

\footnotetext{
${ }^{20}$ In any case, the circulation of economic and political elites in Mozambique was such that even when the concessions ended, the same people who ruled the companies could later work for the state administration. For example, in the 1920s José Ferreira Bossa was director of the Negócios Indígenas
} 
of Salazar's colonial policy: a rationalization of exploitation for the benefit of the mother country and structural underdevelopment of the African colonies (ibid, p. 667).

\subsection{Expenditure priorities and redistributive effects}

The expenditure budgets of Mozambique and Angola consisted principally of expenses on military and marine forces as well as on general administration (administração geral). As elsewhere in colonial Africa, the military forces were used not only to combat external threats but also to secure domestic order (see chapter 4). In the early colonial era (1850s-1920s) investments in education and health were not even a distinct expenditure category in the aggregated annual statistics of the Portuguese colonies presented at Boletim Official, as they were included in civil administration services (see Appendix Figures A2.5 and A2.6). However, colonial accounts (Contas da Gerencia) of the following period (1930s-1970s) provided a more detailed classification, including the distinction of social or welfare services.

In any case, the fact that social services were not distinguished from the general administration, while financial and justice services were, indicates the low priority of welfare spending in Portuguese Africa. In 1920, in Mozambique education and health received only $10 \%$ of the budget while by 1960 the share dropped to $5 \%$. During the same period (19201960 ) in Angola, the share of expenditure on education and health ranged from 7 to $15 \%$. Until the 1920s, infrastructural investments were classified as extraordinary expenses, and mainly funded by loans and subsidies from Portugal as well as private capital. However, from the 1930s the colonial states took over the control of most public works (chapter 5). In the postwar era spending priorities started to change, with infrastructure (roads, railways, ports, irrigation) gaining priority. As figures 2.7 and 2.8 show, infrastructural development services (fomento) acquired a growing share of the expenditure budget, while the shares spent on security and administration (colonial government, fiscal administration, justice services, military and marine forces) and social services (education, health, pensions and indigenous affairs) dropped and then remained relatively stable at similar levels in both Angola and Mozambique.

of the Mozambique Company in Manica e Sofala, while in the 1930s he became briefly Minister of the Colonies and in the 1940s he was appointed Governor of Portuguese India (Direito 2013b, p.72). 
Figure 2.7: Shares of public ordinary expenditure in Mozambique, 1930s-1970s

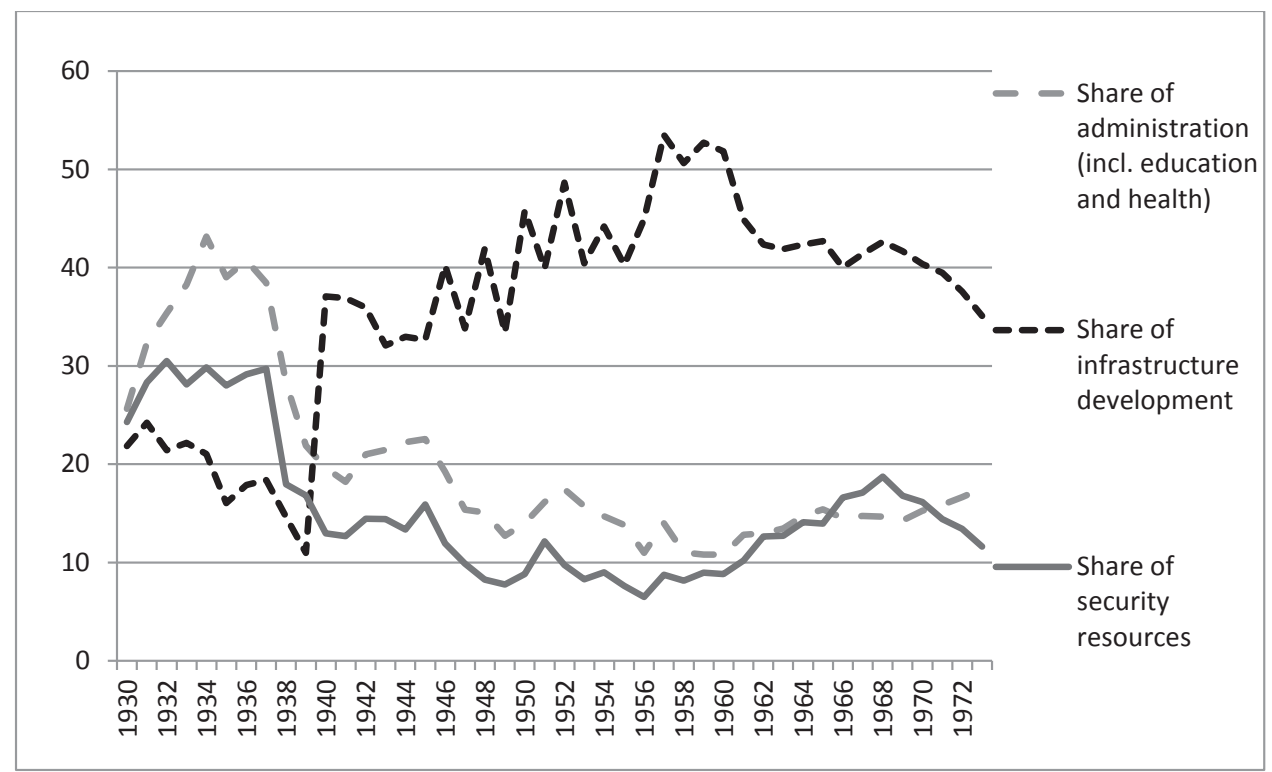

Source: Anuários Estatísticos (Statistical yearbooks) and Contas de Gerência (Accounts) of Mozambique, various issues 1930-1973.

Infrastructure development aimed principally at facilitating the commodity trade with the metropole, South Africa and the neighbouring British colonies. Increasing investments in transportation and communication by the colonial states of Mozambique and Angola can be perceived as a concern for material development, but not necessarily for welfare development. Investments in both infrastructure and social services targeted the urban areas and most importantly the capital cities and the ports of the colonies (Luanda and Benguella in Angola, Lourenço Marques and Beira in Mozambique). Besides serving the trade interests of the metropole and the private capital, the development projects aimed to increase the mobility of armed forces and improve the living standards of the settlers. In other words, they did not serve the needs of the vast majority of the indigenes, who lived mostly in the rural areas (see chapter $5)$. 
Figure 2.8: Shares of public ordinary expenditure, Angola 1930s-1970s

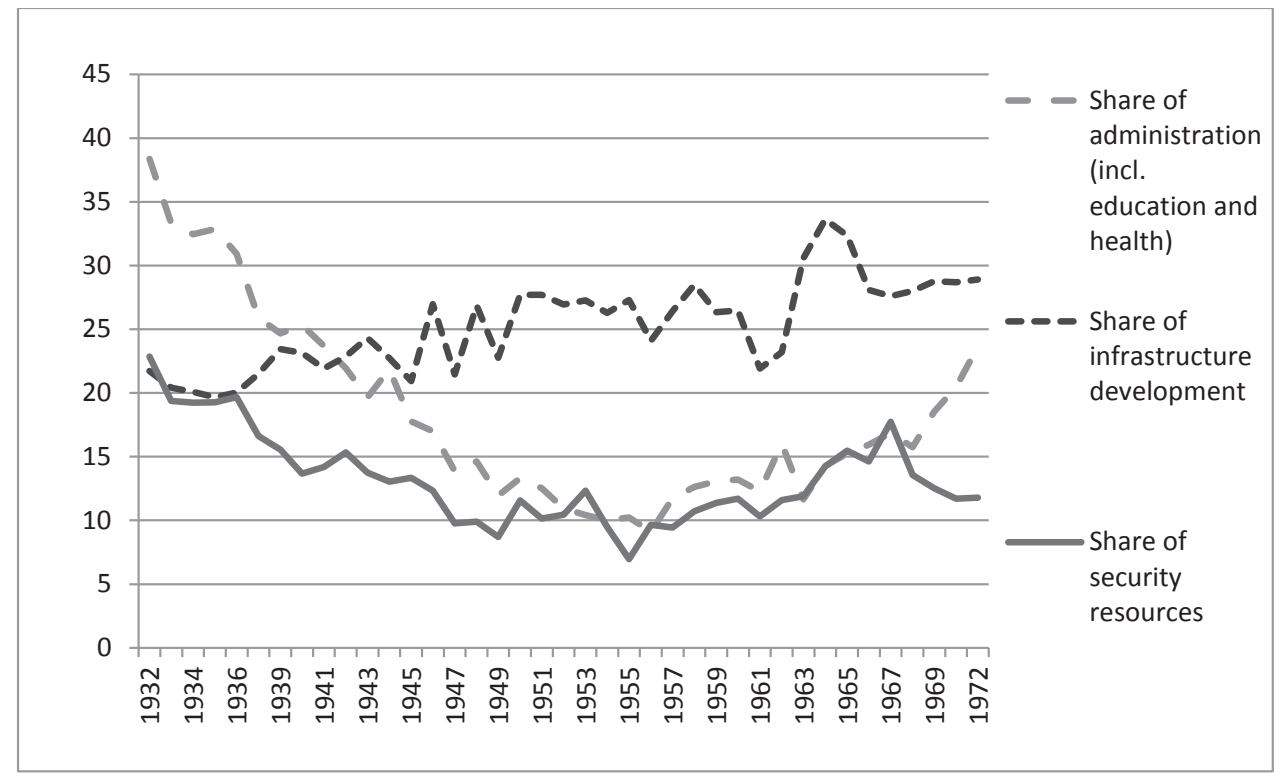

Source: Anuários Estatísticos (Statistical yearbooks) and Contas de Gerência (Accounts) of Angola, various issues 1932-1973.

The same applies to the six-year Development Plans that Portugal initiated in the late colonial era. The first (1953-1958), invested about \$55 million in Mozambique and \$100 million in Angola, mainly in ports, roads, railways and telecommunications (Penvenne et al. 2005, p.84). The second plan invested \$125 million in Mozambique and targeted health, education and agriculture. However, both aimed at increasing white settler migration from Portugal and serving the interests of the existing settler communities in trade, agriculture and irrigation. Also, the threat of the African independence movements in the 1960s motivated to a certain extent these infrastructure investments and settler schemes (Newitt 1995, pp. 46164).

Concerning welfare spending services it should be noted that the catholic church played a major role in the provision of schooling and health care, sending off missionaries to run many of the schools and hospitals. Janeiro (2013) has shown that the religious missions were mainly funded by the colonial states. The shares of these subsidies in the budget were small in both colonies (below 5\% between 1850-1920). From the First Portuguese Republic to Salazar's New State, colonial officials advocated education as a tool to transform the natives into 
“civilized" and cooperative subjects (Cayolla 1912), but educational expenses never gained priority. According to one source, in Mozambique only 33 people had graduated from college by the withdrawal of the Portuguese forces and the granting of independence in 1975 (Kyle 1999, p. 2).

The law of 1917 (Portaria Provincial No 317) stipulated that indigenous people had to fulfill a series of requirements in order to become Portuguese "citizens", such as being fluent in Portuguese and complete basic education (Zamparoni 2000). Under the New State the requirements continued to be highly exclusionary. Moreover, the role of education in the colonies was not always to reduce the gap between the "native" and the "civilized". In Mozambique native children attended "rudimentary" schools focusing on Portuguese culture and manual arts to prepare for manual jobs and were discouraged from attending secondary education (O’Laughlin 2000, p. 15).

Besides the arbitrary criteria set for citizenship and the questionable role of education, the Africans who attained the status of "assimilado", had to pay more taxes and continued to be discriminated in everyday life. In contrast with the French model of governance, which integrated the African elites, Salazar's regime did not encourage the participation of African elites (Keese 2007). The increasing number of settlers migrating from the metropole to the colonies in the period after World War II (Castelo 2007) added another impediment: the colonial states had to recruit the settlers rather than the assimilated elites for the administrational positions in the public sector (Keese 2012, p. 231). Therefore, the objective of assimilation could not sufficiently motivate the colonial states to spend more on education and other welfare services.

The relative increase of public spending on human resources that is observed in the 1960s in both Mozambique and Angola was driven by two forces. First, Portuguese colonial policies met with increasing international criticism. In the 1950s Portugal became a member of multilateral and international organizations such as the United Nations, which "subjected Portugal's colonial policies to international condemnation" (Pinto and Teixeira, 2004, p.113). Portugal was asked to reconsider her policies concerning forced and migration labour, heavy taxation and preferential trade (on the latter see Lains 1998). Also, Portugal was criticized for its military operations against the guerrillas fighting for independence, who started to gain ground in the 1960s, especially in Angola. "What Portugal feared most was further isolation. Criticism from abroad had already begun to hurt" (Venter 2013, p. 223).

Second, Salazar's "New State” was aging, and his successor, Marcello Caetano, started to liberalize some of Salazar's imperial policies from 1968 onwards. In view of the increasing 
support of the indigenes for the independence movements of UNITA, MPLA and FNLA in Angola, as well as FRELIMO in Mozambique, Caetano foresaw the nearing end of the Portuguese Empire. Liberalization policies and investments in public goods could place the metropole in a better position to negotiate its future relations with the colonies. Ironically, the independence wars in both colonies forced Portugal to raise its military and security expenditures to about 45 per cent of its annual budget (Pinto and Teixeira 2004, p. 117).

\subsection{Conclusion}

This chapter has indicated the decisive role of the metropole in determining the colonial fiscal policies as well as the importance of local conditions and disparities between and within the two colonies. To what extent did these influence the development of a modern fiscal state?

On the first condition of fiscal modernization, the capacity of the state to centralize revenue collection, the conclusion is that it took long before the colonial state broke through the stakes of private concession companies and local African leaders, who employed diverse strategies from resistance to cooperation in order to keep the state at arm's length. In the 1890s certain areas of central Mozambique passed from the authority of prazeros to the control of large concession companies which mainly invested in plantation agriculture. As a result, certain zones were administered by private actors and remained out of the supervision of the colonial state apparatus. This led to less centralization in decision-making and tax management. The consolidation of the fiscal state was eventually enforced by the Salazar regime.

The Portuguese based their colonial rule on military superiority. Spending on military forces dominated the early colonial budgets, and especially in Angola. The Portuguese used both direct violence and a system of indirect rule, delegating tax collection to native chiefs and rewarding them for their services. The ethnic diversity and the existence of multiple centers of power, especially in nineteenth century Mozambique, played a dual role: on the one hand, they hindered administrative unification; on the other hand, they may have belated the eventual overthrow of the colonial power. Nevertheless, the revenue mix became more diversified than in many other African colonies. Indirect taxes played a major role, especially in Angola, but the development of property taxes, corporate income taxes and sales taxes did induce a more fine-grained system of income and asset assessment over time.

On the second condition of fiscal modernization, the creation of long-term debt and the ability of the state to fund larger development projects it can be concluded that fiscal 
modernization was curbed by the straitjacket of Portugal's imperial dictatorship. The elimination of debt and the dogma of budget balance were core principles of Salazar's authoritarian regime. Most of the loans were offered by the metropole and the levels of financial development and monetization in both Mozambique and Angola were low. Throughout the colonial era, the Portuguese metropole swung between administrational autonomy, following the British approach to empire, and power centralization, adopted by the French Empire. Administrative and financial autonomy was given to the colonies during the Republicans' governance in Portugal, while during Salazar's governance fiscal controls by the metropole were intensified, including restrictions on colonial government borrowing.

The same applies to the third modernization condition: public investments in welfare services remained very low. Only in the late colonial years, under the pressure of international organizations and independence movements, the colonial governments initiated development projects aimed at improving African living standards. Public revenues that were not allocated to military and administrative capacity building, went mainly into infrastructural projects that facilitated imperial trade. Catholic missionaries filled part of the gap, but the subsidies they received for their mission schools and hospitals remained tiny.

Finally, the fourth condition of fiscal modernization, the existence of a representative government, with a system of checks and balances, to ensure legitimacy and tax compliance, was a requirement that colonial rule by definition could not meet. However, this condition was also not met in the metropole. In the framework of "compulsory globalisation" (Hopkins 2002) Portuguese Africa passed from peasant or feudalist societies to capitalist production, but this transformation was not accompanied by the emergence of modern political and fiscal institutions. 


\section{Appendix}

Figure A2.1: Revenues from main export commodities in Mozambique, 1926-1970

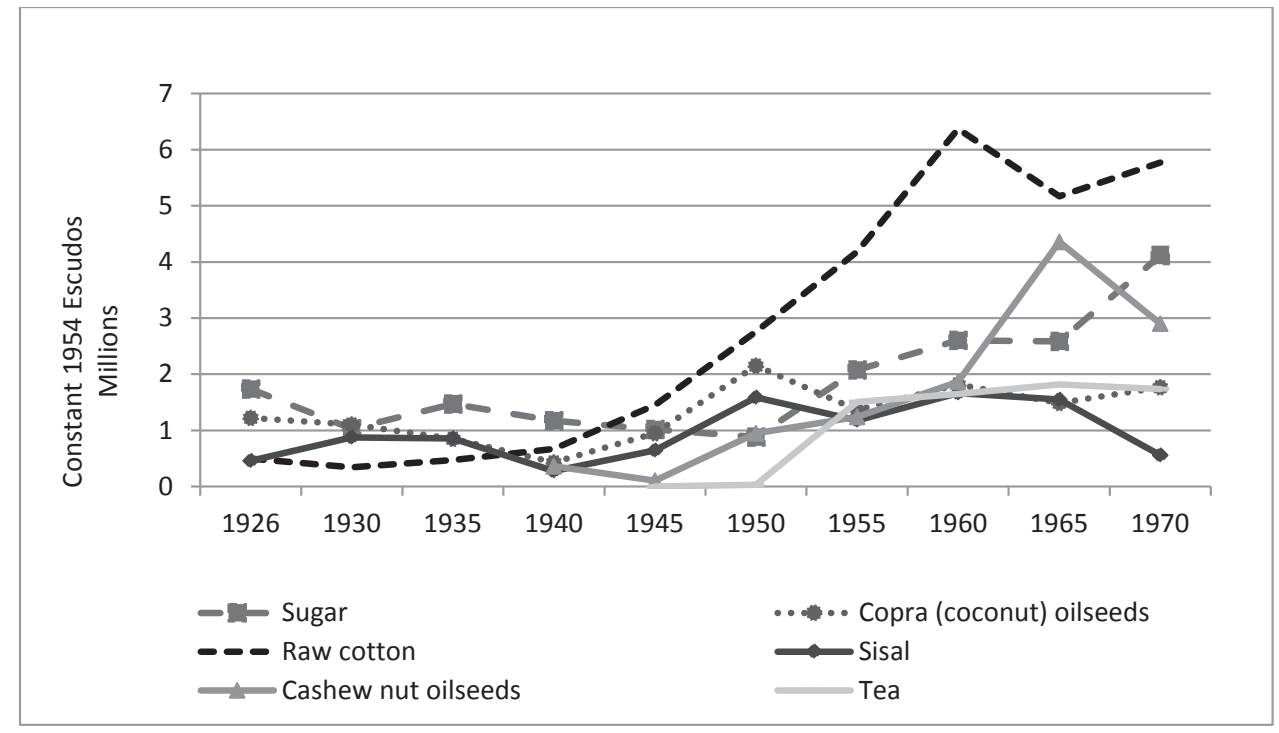

Source: Anuários Estatísticos (Statistical yearbooks) of Mozambique, various issues 1926-1970; Price deflator: WPI from Mitchell (2008) Table H1.

Figure A2.2: Revenues from main export commodities in Angola, 1930-1970

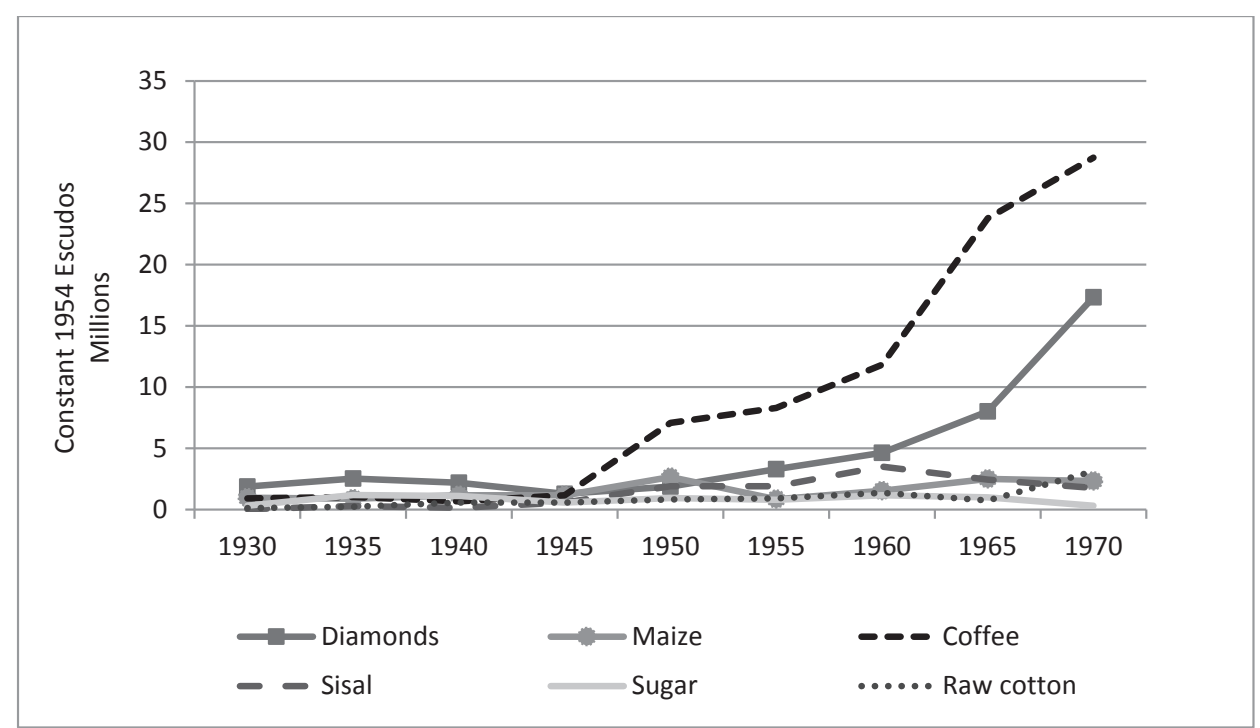

Source: Anuários Estatísticos (Statistical yearbooks) of Angola, various issues 1930-1970; Price deflator: WPI from Mitchell (2008), Table H1. 
Figure A2.3: Real revenue and expenditure per capita in Angola, 1932-1973

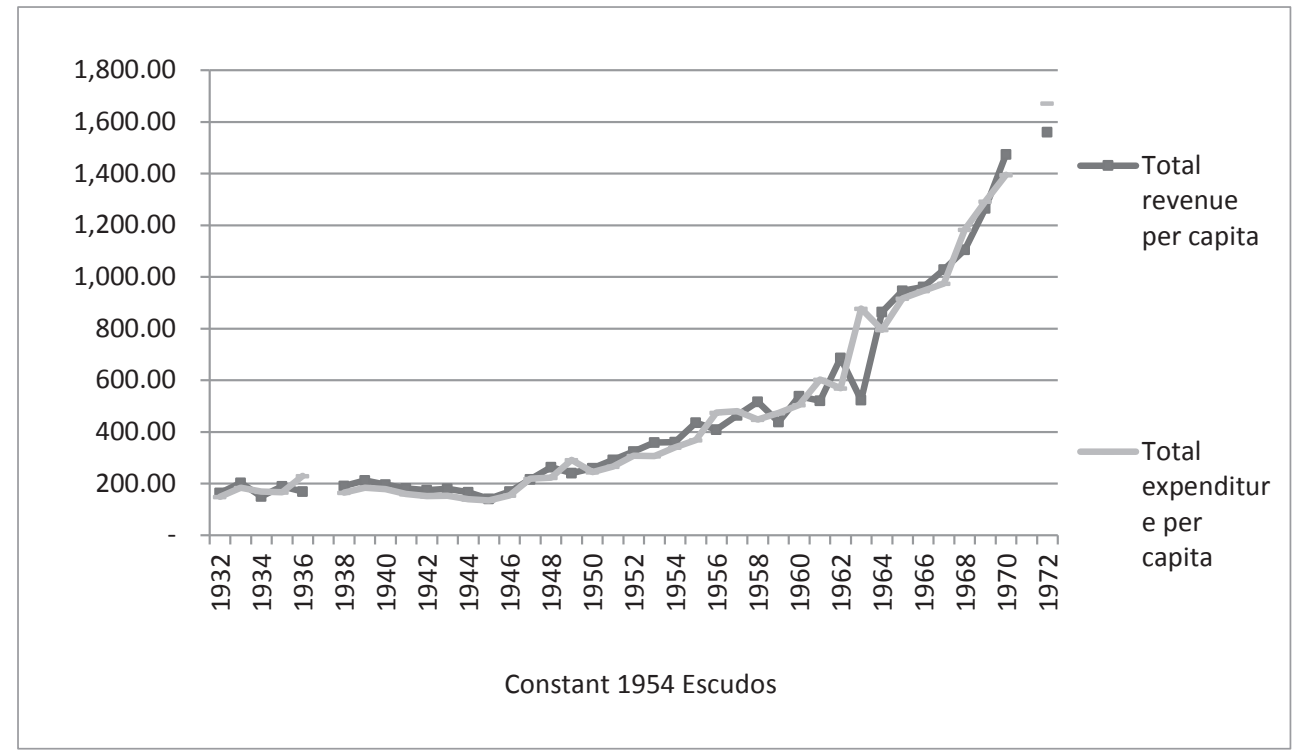

Source: Anuários Estatísticos (Statistical yearbooks) and Contas de Gerência (Accounts) of Angola, various issues 1932-1973; Price deflator: WPI from Mitchell (2008), Table H1.

Figure A2.4: Real revenue and expenditure per capita in Mozambique, 1929-1973

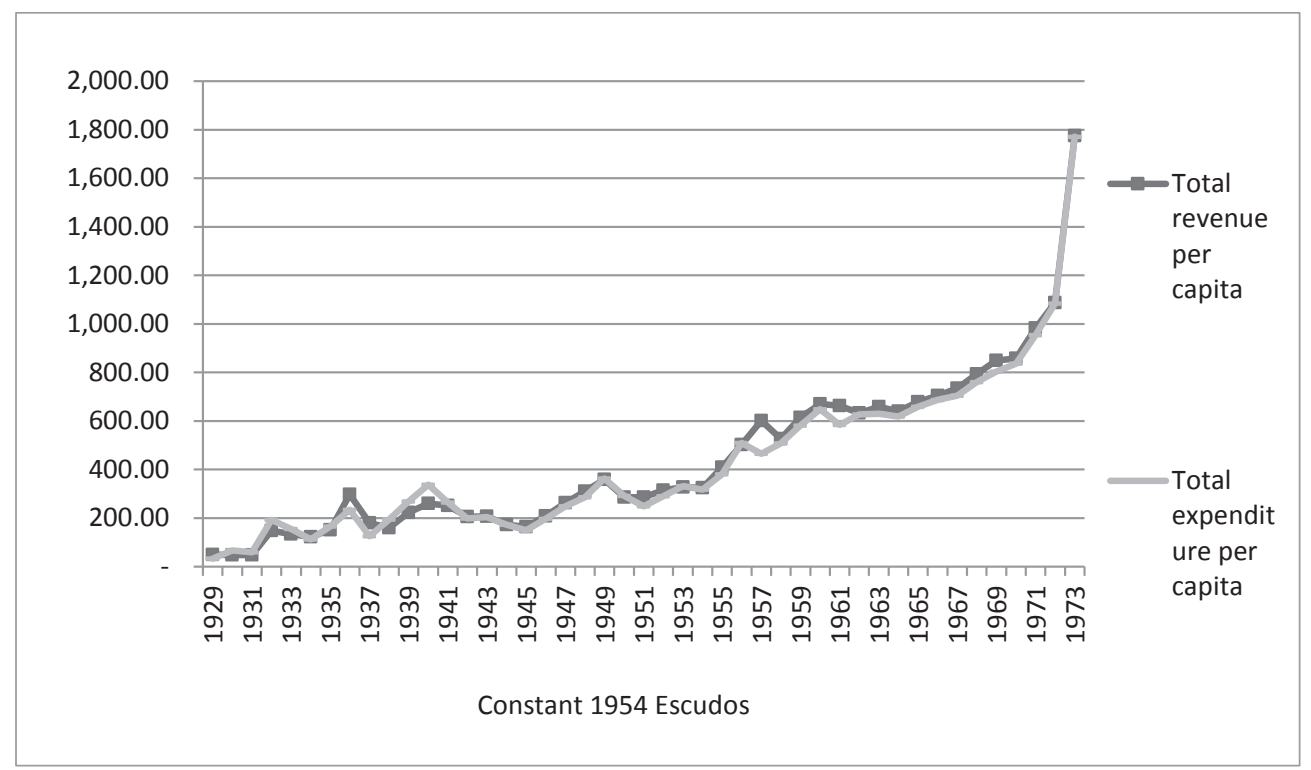

Source: Anuários Estatísticos (Statistical yearbooks) and Contas de Gerência (Accounts) of Mozambique, various issues 1929-1973; Price deflator: WPI from Mitchell (2008), Table H1. 
Figure A2.5: Real public ordinary expenditure, Angola, 1850-1916

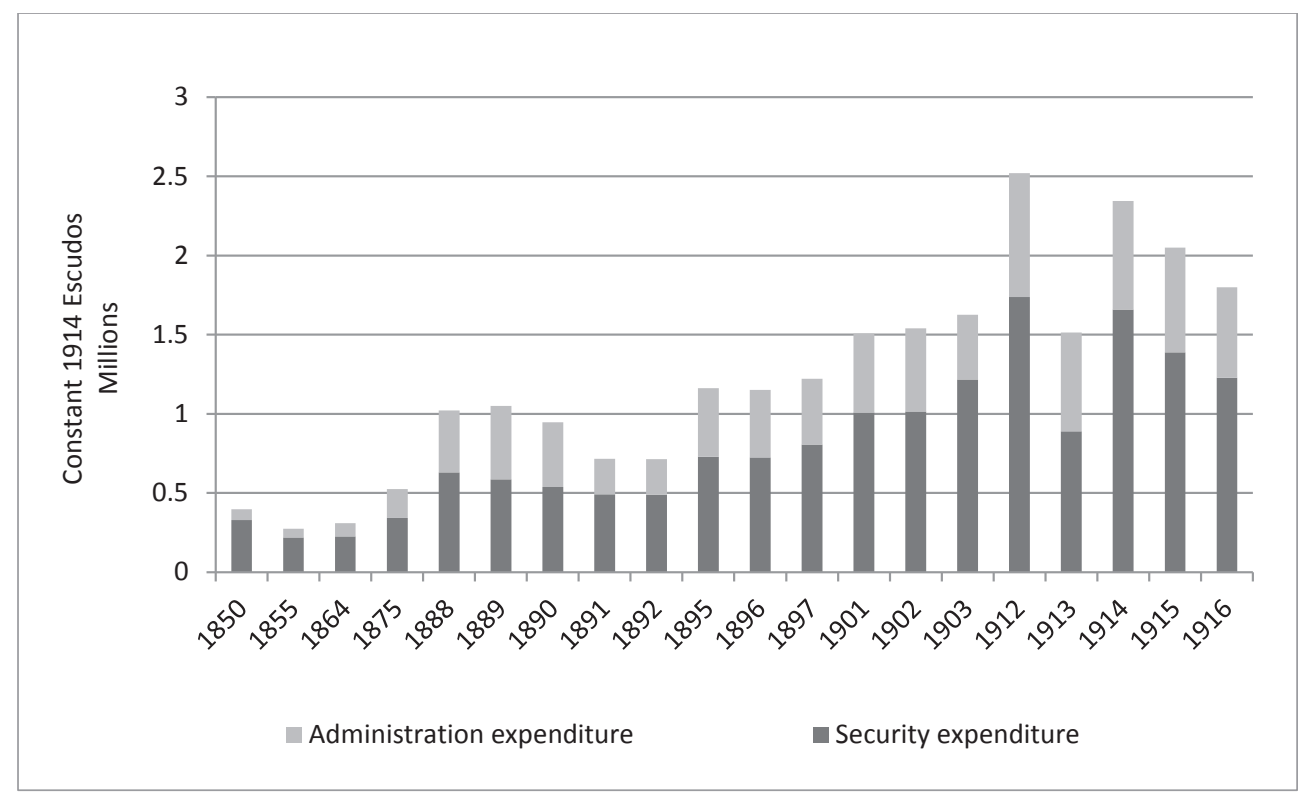

Source: Boletim Official, Price deflator: Valerio (2001), Table 8.1.

Figure A2.6: Real public ordinary expenditure, Mozambique, 1857-1918

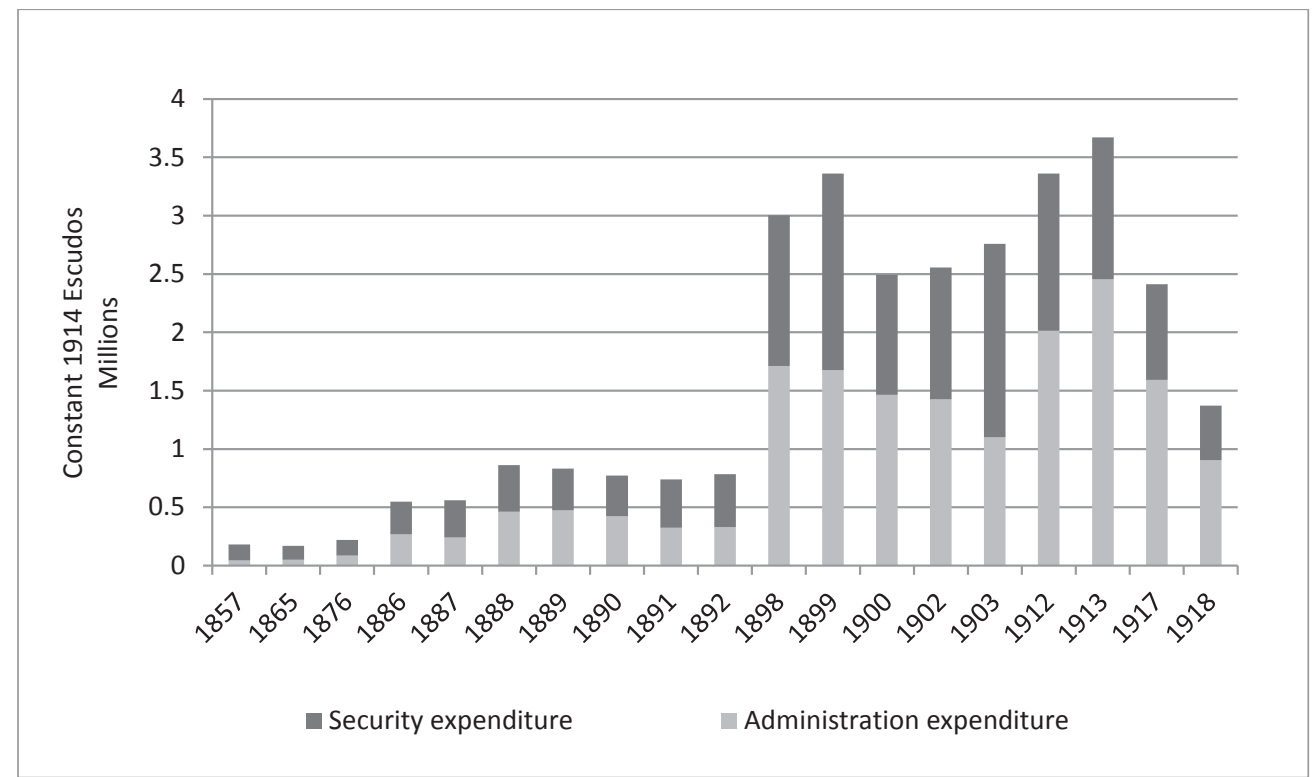

Source: Boletim Official, Price deflator: Valerio (2001), Table 8.1. 
Figure A2.7: GPR per capita in Portuguese, British and French African colonies

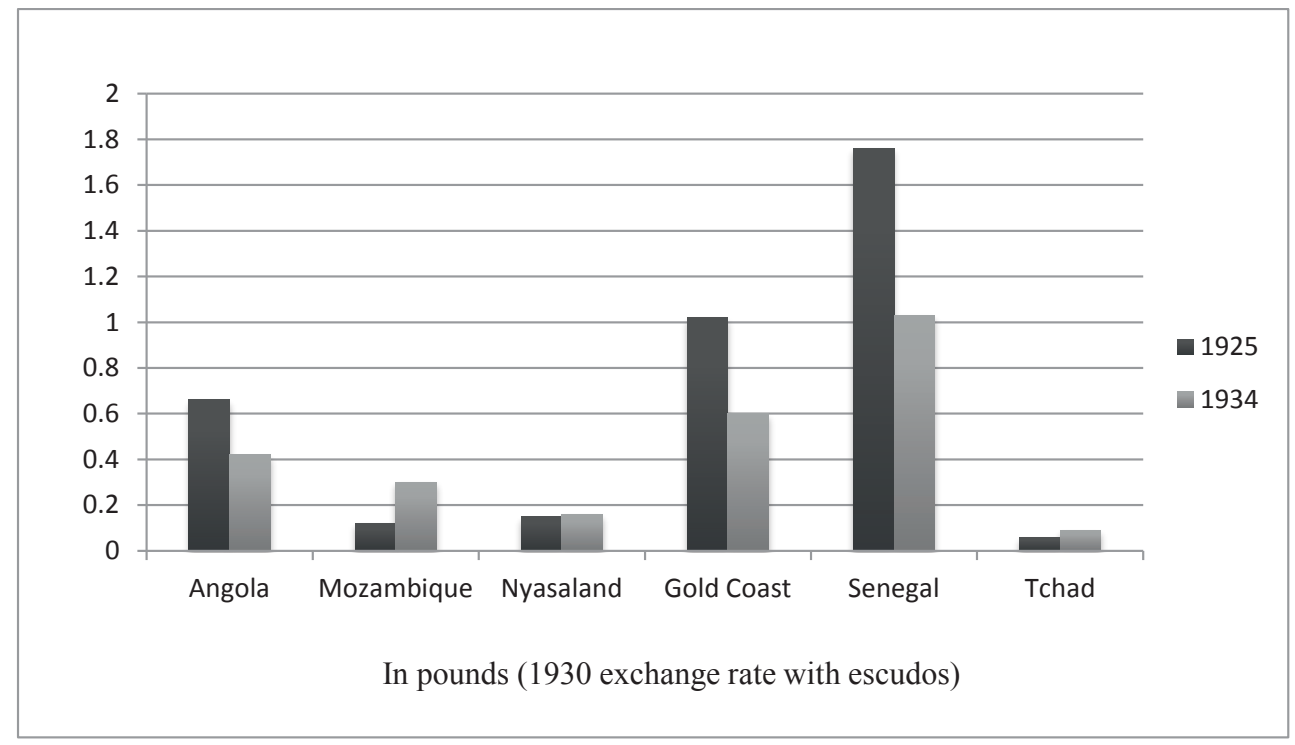

Source for British and French colonies: Frankema and Waijenburg (2014);

For Portuguese colonies: Anuários Estatísticos (Statistical yearbooks) of Mozambique and Angola. 


\title{
Chapter 3
}

\section{Colonial State Formation Without Integration: Tax Capacity and Labour Regimes in Portuguese Mozambique, 1890s-1970s ${ }^{21}$}

\begin{abstract}
Samir Amin (1972) divided the African continent into three "macro-regions of colonial influence" with distinct socio-economic systems and labour practices: Africa of the colonial trade or peasant economy, Africa of the concession-owning companies, and Africa of the labour reserves. We argue that Mozambique encompassed all three different "macro-regions" in one sole colony. We reconstruct government revenue (direct/indirect taxes) raised at a district level between 1930 and 1973 and find persisting differences in the "tax capacity" of the three regions throughout the colonial period. The tax systems, we claim, developed in response to existing local geographic and economic conditions, particularly to labour practices. Portuguese colonial rule adapted to and promoted labour practices such as migration and forced labour to maximize revenue. The extent to which the lack of integration played a role in the post-colonial state and fiscal failure should be studied further.
\end{abstract}

\footnotetext{
${ }^{21}$ A version of this chapter has been published as Alexopoulou, K. and Juif, D. (2017). "Colonial State Formation Without Integration: Tax Capacity and Labour Regimes in Portuguese Mozambique (1890s1970s).” International Review of Social History, 62(2), 215-252.
}

Acknowledgement note: We would like to thank Ewout Frankema, Elise van Nederveen Meerkerk, Jutta Bolt, Pieter Woltjer, Kostadis Papaioannou, Christina Mumme, Carsten Burhop, Erik Green, Rachel Meyer, as well as three anonymous referees and the editorial board for their insightful comments. We also owe our gratitude to the archivists and librarians in Lisbon, Maputo, and Pretoria for their valuable advice and to Jessica M.C. Lima for her assistance; to the participants of the Workshop on "Colonialism, Growth and Development in the Southern Hemisphere, 1800-2000" at Lund University (April 2015); as well as to the participants of the ERSA workshop on "The Fiscal History of Sub-Saharan Africa" at Stellenbosch University (May 2015) and of the Social Science History Association conference in Baltimore (November 2015). We are grateful for the working paper version published by the African Economic History Network (AEHN) and for the financial support provided by the Netherlands Organization for Scientific Research (NWO) as part of the VIDI project "Is Poverty Destiny? Exploring Long-Term Changes in African Living Standards in Global Perspective". The usual disclaimer applies. 


\subsection{Introduction}

Fiscal or tax capacity, defined as the ability of the state to collect revenue and invest in statebuilding, determines the scope for the state to provide public goods, which in turn has consequences for economic development and well-being. ${ }^{22}$ Fiscal capacity is a crucial component of "state capacity", defined as the "degree of control that state agents exercise over persons, activities, and resources within their government's territorial jurisdiction" (Tilly et al. 2001, p.78). It is widely held that modern state and fiscal capacity are essentially shaped by historical developments (Tilly 1990). ${ }^{23}$

Many post-colonial states in Africa, including Mozambique, are often considered failed or fragile. ${ }^{24}$ Following colonialism, the legitimization of these independent African states is low and taxation is imposed by force rather than by consent. It is therefore crucial to study the historical origins of these states, the conditions under which they were formed, and the transformations they underwent. The development of fiscal systems was an important aspect of state formations in Africa by European colonial powers, as posited in the Berlin Act of 1885 . Yet, imposing direct taxation in colonial times was a particularly costly undertaking, constrained by local geographic and economic conditions. Moreover, it occasionally turned out to have unwelcome consequences, such as mass emigration and even armed resistance. Therefore, colonial powers usually limited their investments in fiscal capacity to the urban centres with strong European presence.

As recent scholarship has shown, there was also diversity in tax capacity across African colonies, mainly shaped by local geographic and commercial conditions. ${ }^{25}$ Two recent studies argue that the significant differences in fiscal capacity within contemporary sub-Saharan Africa

\footnotetext{
${ }^{22}$ Besley and Persson view state capacity as the ability to effectively implement policies that foster economic growth, with fiscal and legal capacity being its principal components (2010, p.6).

${ }^{23}$ Tilly holds that past wars in Europe created an incentive for the state to invest in institutions enabling revenue to be raised from the population. This theory was tested empirically by Dincecco et al. (2014). ${ }^{24}$ Post-colonial Mozambique can be considered an example of state failure with historical roots. Persistent economic and political fractionalization created a fertile ground for internal conflict. After the Mozambican War of Independence (1964-1974), civil war dominated for fifteen years (1977-1992). See Collier and Sambanis (2005, p.161).

${ }^{25}$ For example, Frankema and van Waijenburg (2014) claim that "the formation of the fiscal state was primarily determined by the opportunities and constraints set by local commercial and environmental conditions". This view goes against some of the earlier African economic history literature, which emphasized the role of colonial identity in shaping institutions in Africa.
} 
have historical roots and are closely linked to colonial labour policies and practices (Mkandawire 2010, Feger and Asafu-Adjaye 2014).

One way of unravelling these colonial roots is to follow Samir Amin's threefold categorization of "macro-regions of colonial influence": 1) "Africa of the colonial trade economy", areas with a long tradition of international trade, where indigenous peasants produced cash crops for the European market; 2) "Africa of the concession-owning companies", where colonial governments granted large land concessions and mineral rights to private companies, which partly took over the administration and tax collection in their territory; 3 ) "Africa of the labour reserves", territories in southern Africa where the good climate and geography favoured large European settlements, and a large labour pool was readily available for the surrounding mines and settler farms (Amin 1972). In the latter group of countries, colonial policy backed the interests of industry and settlers with regard to pushing the indigenous population into wage labour by land expropriations and by raising hut or poll taxes. In panel and cluster regression analyses Mkandawire (2010) as well as Feger and Asafu-Adjaye (2014) find that the labour reserve economies are still characterized by the highest tax levies, followed by cash-crop-trade and concession economies. In the labour reserves, they argue, the interest in a booming mining and farming sector - as well as the intention of many Europeans to settle long term - motivated the colonial administration to be more interventionist, whereas in cash-crop and concession economies the involvement of the state in developing solid institutions was kept to a minimum.

Nonetheless, not all African countries fit Amin's categorization. For instance, although Amin placed Mozambique in the category of labour reserves, one could also argue that the Portuguese colony was not only a labour pool, and that it encompassed all three economic zones. ${ }^{26}$ The north was to a large extent a peasant-based economy, the central region was exploited by concession companies and was dominated by forced labour, and the south functioned as a labour reserve for the mines of South Africa and Southern Rhodesia (now Zimbabwe). We argue that the different labour regimes in the north, centre, and south resulted in an unintegrated fiscal state. The south developed much stronger state capacity than the north and the centre. First, indigenous labour migration to the mines became a rich source of tax revenue. Second, this became the region where most Europeans settled, and where Lourenço Marques (now Maputo), the capital of Mozambique, has been located since 1898. The peasant-

\footnotetext{
${ }^{26}$ On the persistence of three distinct geographic zones in Mozambique from the perspective of agricultural production, see Bowen (2000, p. 32).
} 
based north, where large parts of the population were subsistence farmers, became the region with the weakest tax capacity. The centre, outsourced to concessionary companies, was not particularly effective in collecting taxes either, but developed a strong reliance on forced labour that allowed companies and state to save expenses on wages and combat labour scarcity.

Unlike Feger and Asafu-Adjaye and Mkandawire, who do not provide tax data for the colonial period and merely assume the temporal stability of colonial labour practices, ${ }^{27}$ we provide empirical evidence on taxation and labour practices in Mozambique from the early colonial period until independence, and show a strong persistence of regional differences. Focusing on one sole colony has the advantage that we can abstract from the metropolitan identity as a source of variation and shift our attention to the interaction between local conditions and fiscal capacity. We add the case of a Portuguese territory to the literature on colonial fiscal development in Africa that has mostly excluded Lusitanian dominions (Frankema 2010, pp. 447-477; Frankema 2011, pp.136-149; Gardner 2012). The spending side, which could also be considered an important aspect of fiscal capacity, is outside the scope of this chapter.

For our quantitative analysis we reconstruct real tax revenue per capita and the tax composition (direct/indirect taxes) of the three regions (nine districts in total) of Mozambique for much of the colonial period (1930-1973). ${ }^{28}$ We then focus primarily on direct and particularly on indigenous taxation (imposto de palhota / imposto indigena), consisting of hut or per capita taxes imposed by the Portuguese state on the indigenous population at fixed rates (Colonia de Moçambique 1946). Direct taxation is generally more strongly associated with state capacity than indirect taxation, which is related more to the availability of an easy source of revenue such as trade. (Herbst 2000). ${ }^{29}$ The data on revenue was collected from the public finance statistics published in the colonial statistical yearbooks and accounts of Mozambique, at the Instituto Nacional d' Estatística (INE) in Lisbon. From the yearbooks, as well as from additional sources found at the Historical Archive of Mozambique (AHM) and the Centre for African Studies at Universidade Eduardo Mondlane (UEM) in Maputo, we retrieved

\footnotetext{
${ }^{27}$ Mkandawire (2010) and Feger and Asafu-Adjaye (2014), "Tax Effort Performance", compare postcolonial African tax systems from a "colonial legacies" perspective. They identify different kinds of colonial labour regimes (atemporal) as the root cause of differences in fiscal capacity from the 1980s to 2000s, but they do not provide data for the colonial period. This line of literature has been criticized by Gareth Austin (2008b) for "compressing history".

${ }^{28}$ The whole territory was transferred to the control of the Portuguese colonial government between 1929 and 1942. Before, parts of it were under the complete control of concession companies.

${ }^{29}$ Consumption taxes, on the other hand, were insignificant in colonial Africa.
} 
information on the number of migrant workers and other demographic, geographic, and economic factors at a provincial level. ${ }^{30}$ For the qualitative part of the chapter, we make use of colonial reports that shed light on taxation and labour practices, including chain migration to South Africa, coercive labour, and forced cropping. ${ }^{31}$ We explain the lack of integration as a result of local conditions (including labour practices) and the rule of a relatively weak imperial power in economic terms. We also argue that the Portuguese colonial government not only failed to unify the fiscal system, but even exacerbated these regional differences.

The chapter is structured as follows: the first section presents an overview of fiscal systems in colonial Africa and in Mozambique specifically. The second section gives a historical overview, including qualitative and quantitative evidence of the distinct characteristics of the three zones of Mozambique that affected fiscal capacity-building in the colonial era. The third section is an empirical analysis of tax revenue, showing the differences in direct taxation and its determinants between the north, the centre, and the south. The fourth section explains why state formation took place without integration, and the final section concludes.

\subsection{Fiscal capacity-building in colonial Africa and Mozambique}

One of the most important aims of early colonial administrations in Africa was to introduce a system of tax collection. ${ }^{32}$ First, taxation was a prerequisite for "effective occupation" and legitimization of power, as defined in the Berlin Conference. ${ }^{33}$ Crawford Young analysed the

\footnotetext{
${ }^{30} \mathrm{We}$ are aware that colonial records can be biased in certain aspects, for example in the profiling of Africans as unindustrious. However, if population and tax records are biased, we can expect the bias to be either equally distributed among districts or undercounting to be more prevalent in the north, where state capacity was lowest and administrative control weakest. This bias would then actually strengthen our main argument concerning fiscal inequality between the three regions.

${ }^{31}$ Portuguese Mozambique relied longer than other colonies on forced labour, and sent large numbers of migrant labourers to the mines in South Africa and Southern Rhodesia. As Penvenne stated, the history of Mozambique is "largely the history of the international leasing of migrant labour outside the country and the national commandeering of forced labour within the country" $(1979$, p.2).

${ }^{32}$ The colonial states and fiscal systems were more or less exogenously imposed, in contrast to the longterm evolution they underwent in Western Europe (Tilly 1990).

${ }^{33}$ In the General Act of the Berlin Conference, which can be seen as formalizing the Scramble for Africa, the principle of "effective occupation" stated that powers could acquire rights over colonial lands only if they possessed them or had treaties with local leaders, flew their flag there, and established an administration in the territory, governing it with a police force to keep order (Herbst 2000, pp. 71-72).
} 
development of the colonial African state based on the concepts of effective occupation and "hegemony imperative" (1988, p.2), which implied the establishment of hegemonic institutions (military outposts and networks of administrative centres). Second, the revenue imperative also in place in the Portuguese empire - implied that it was necessary for the colonial state to raise taxes in order to finance itself without putting a burden on the metropole (Gardner 2012, p.40). Third, imposing indigenous (direct) taxes was important to help "develop" the colony. It was supposed to have disciplinary power, by forcing the indigenous population to produce for the market or pushing it into wage labour, and it was also meant to contribute to the monetization of the economy. ${ }^{34}$

From the 1870 s to the 1900 s, indigenous taxes in Mozambique could be paid either in kind or in cash, depending on the area. However, the advantages of direct taxes paid in money (saving storage and transportation costs, and pushing the indigenes to the wage labour market) soon became undisputable and the system of indigenous cash taxes was gradually introduced in the whole territory in the early twentieth century. ${ }^{35}$

The levying of indigenous taxes in Mozambique and the rest of Africa was, however, not an easy task and thus many colonial states relied on indirect taxes as much as possible. Overall, it has been claimed, colonial states in Africa were mostly "gatekeeper states" whose power was limited to controlling the borders and thus to collecting trade taxes (Cooper 2002). First, a complex state apparatus was needed in order to raise direct taxes, and putting it in place was costly, as it involved recruiting and training tax inspectors and investing in systems of control. Second, imposing hut and poll taxes often caused resistance, which was costly to subdue. Third, it could lead to undesirable mass emigration, often from underpopulated regions

\footnotetext{
${ }^{34}$ Already in the 1890 s, the prominent regional commissioner of Mozambique, António Enes, had expressed his views on the crucial role of indigenous people as taxpayers and (either free or unfree) wage workers in the process of monetization and labour intensification, which would eventually contribute to agricultural development and the expansion of "civilization" (Ferreirinha 1947, p. 5). For Enes this was the principal mission of colonialism. Taxation in the whole of colonial Africa has been perceived as a "discipline" and penal tool, in Foucauldian terms, that aimed at moralization and the stimulation of Africans' industriousness (Bush and Maltby 2004).

${ }^{35}$ In the early years of the twentieth century, the governor of Lourenço Marques in Mozam bique argued against the payment of taxes in kind. In his notes he highlighted, among other things, the transportation and storage costs derived from such transactions as well as the fluctuating prices and thus the questionable value of the exchangeable products. But most importantly, he emphasized the scarcity of labour in the area, caused by the fact that indigenous people did not need to pay taxes in money, so they did not need to work for companies to receive wages (Aguiar n.d., pp.75-76). Therefore, payment in kind constrained the effectiveness of colonial rule and hampered the economic development of the region.
} 
such as the central and southern zones of Mozambique. Fourth, many areas in Africa, such as the north of Mozambique, were not monetized, at least in early colonial times. Since indigenous peasants relied on subsistence farming, cash tax payments were difficult to collect. However, the Mozambique colony, where natural resources were scarce and trade volumes were relatively insignificant, had to rely to a much larger extent on direct taxation than many other colonies. For instance, the value of exports per capita in Mozambique was one-third of Belgian Congo's in 1960, and less than half the value of per capita exports in Portuguese Angola (Mitchell 2007). This seems to confirm the claim by Frankema and van Waijenburg in their study on French and British Africa: "The highest direct tax shares were to be found in the least commercialized areas" (Frankema and van Waijenburg 2014 p. 383). More commercialized and coastal regions (controlled to a larger extent by the British) had higher levels of taxation but also a lower share of direct to total taxes.

Colonial states also relied on forced labour for building their infrastructure while saving public expenditures on wages. Van Waijenburg (2018) argues that forced labour functioned as an implied type of government tax in French West Africa. She calculated the costs saved on wages through the use of forced labour as a proportion of total state revenue. ${ }^{36}$ Similarly, in Portuguese Mozambique, forced labour was used as a complement to direct taxes. Especially in areas that were not monetized and where labour was needed for plantations, the state and concession companies relied heavily on forced labour. Until 1962, various forms of forced labour were in place in Mozambique: coercive (compelido) and punitive (correcional) labour, domestic labour by women working in European households, and forced labour exile, for instance to the cocoa plantations in São Tomé (Kagan-Guthrie 2011). O'Laughlin (2002) notes that both men and women were pressured into variable periods of punitive labour (corvée) for non-criminal offences such as evading taxes or escaping from contract labour. Although the Portuguese colonies in Africa were not the only ones to rely on forced labour, they did so for much longer than the French and British, despite international pressure. Portugal did not ratify ILO (International Labour Organization) agreements on the abolition of forced labour in its colonies until 1956, while Britain had already complied with international labour standards in 1930 and France in 1937.

The strategic choice of colonial governments was to raise monetary taxes in order to push the population into wage labour, as well as to promote wage labour to be able to raise

\footnotetext{
${ }^{36}$ Unfortunately, consistent data on forced labour at a district level are not available for this exercise for Mozambique.
} 
taxes, as we will argue below. However, wherever cash tax payments and wage labour were not effective, forced labour practices were used as a complementary tool not only to save expenditure but also to impose discipline.

A number of studies have recently reconstructed historical taxation in Africa from colonial budget accounts and aimed to explain regional differences in fiscal capacity (Frankema and van Waijenburg 2014; Albers and Suesse 2015). The present study adds the case of Mozambique to this literature, which has largely neglected Portuguese Africa. Like Feger and Asafu-Adjaye, and Mkandawire, we argue that colonial labour practices, categorized along the scheme suggested by Samir Amin, can explain differences in taxation. Unlike them, we provide empirical evidence on taxation and labour practices on a yearly basis for a large part of the colonial period. In a historical narrative, we also aim to unravel the connection between the two.

\subsection{Historical background}

\section{From prazo feudalism to colonial concession companies and state administration}

In the explorations era (fifteenth century), a few trading posts and harbours were established by the Portuguese on the coast of Mozambique and along the Zambezi river. From the eighteenth to the nineteenth century the Zambezi region in the centre of Mozambique was dominated by prazo holders. Prazos were originally land tracts granted by the Portuguese Crown to Portuguese merchants. However, through intermarriage the prazo community became a mix of Portuguese and Africans. Prazo holders controlled large amounts of land, with the support of strong armies consisting of indigenous people. In the mid-nineteenth century, Portuguese activities in eastern Africa were focused mainly around these settlements along the banks of the Zambezi (Newitt 1969, p.67). A direct tax called mussoco was imposed on the indigenes by the prazos, which until the 1900s was usually paid in kind (Ishemo 1989). The economy was mainly based on agriculture, but prazo holders were also heavily involved in the slave trade. This region, at the centre of Mozambique, was characterized by a long tradition of trading coercive labour. Clandestine slave trading continued in Mozambique even after the 1842 AngloPortuguese agreement had attempted to prevent it (Pitcher 1991, p.50). Slave trading was one of the main factors causing depopulation and labour shortage in Mozambique during early colonization. Indigenous people often emigrated to avoid being recruited by force. 
By the 1850s local peasants from the south of the colony were moving to Natal in South Africa to work on plantations, while from the 1870 s onwards they started to migrate to the diamond mines in Kimberley and from 1886 to the gold mines in Transvaal (Pitcher 1991, p.49). In contrast, in northern Mozambique Africans still had access to land and subsistence production as well as to markets. For centuries, the population of the north had conducted trade with Arabs, who established trading centres and sultanates on the coast of eastern Africa. This commerce and the ability of peasants to continue with their livelihood partially explain why from the 1890s onwards concession companies had difficulties controlling northern Mozambique.

Under the international pressure of the Scramble for Africa in the 1880s, Portugal had to secure and expand the "effective occupation" of its African territories. By the 1890s, different cultural and political regions could be distinguished in Mozambique: a coastal zone under Portuguese control; a northern region of peasant agriculture, still under the influence of Islamic chiefs who performed long-distance trade; the central region of the Zambezi valley inhabited by prazos (however in decline); the African kingdom of Gaza and the Delagoa Bay (today Maputo Bay) in the south (Newitt and Tornimbeni 2008, p.710). After the defeat of the Gaza kingdom (1895) and the gradual integration of prazos into the colony, the political and cultural differences between these regions led to the formation of three zones (north, centre, and south) with distinct economic systems that persisted throughout the twentieth century. Each zone consisted of three districts that, in some cases, changed names over time. We harmonize the district names and boundaries according to the regional division of 1959 to 1973 . The north comprises Niassa, Cabo Delgado, and Mozambique; the centre, Zambezia, Tete, and Manica e Sofala; and the south, Inham bane, Gaza, and Lourenço Marques (see m ap 3.1).

In order to facilitate the establishment of its colonial rule, from the 1890s Portugal delegated the administration of central (and part of northern) Mozambique to chartered companies, which were allowed to raise taxes, to exploit natural resources (land and minerals), and to have their own police force. This expenditure-saving practice was used by other colonial powers in Africa as well, such as in Belgian Congo and British Northern and Southern Rhodesia. However, the Belgian and the British colonial powers abolished the concessions of administrative authority in 1908 and 1924 respectively. In Mozambique, three companies shared around fifty per cent of the whole colony's territory: the Niassa Company (1891-1929) was active in the northern zone; the Mozambique Company (1891-1942) and the Zambezia Company (1892) operated in the central zone. The Zambezia Company was a leasing company (founded without a charter) and became the largest of the three. The concessions were 
considered ineffective in terms of capital accumulation and tax revenue and were not renewed by Salazar's "New State" regime that dominated Portuguese imperial politics from 1932 to $1974 .{ }^{37}$

Map 3.1: Districts of Mozambique, 1963

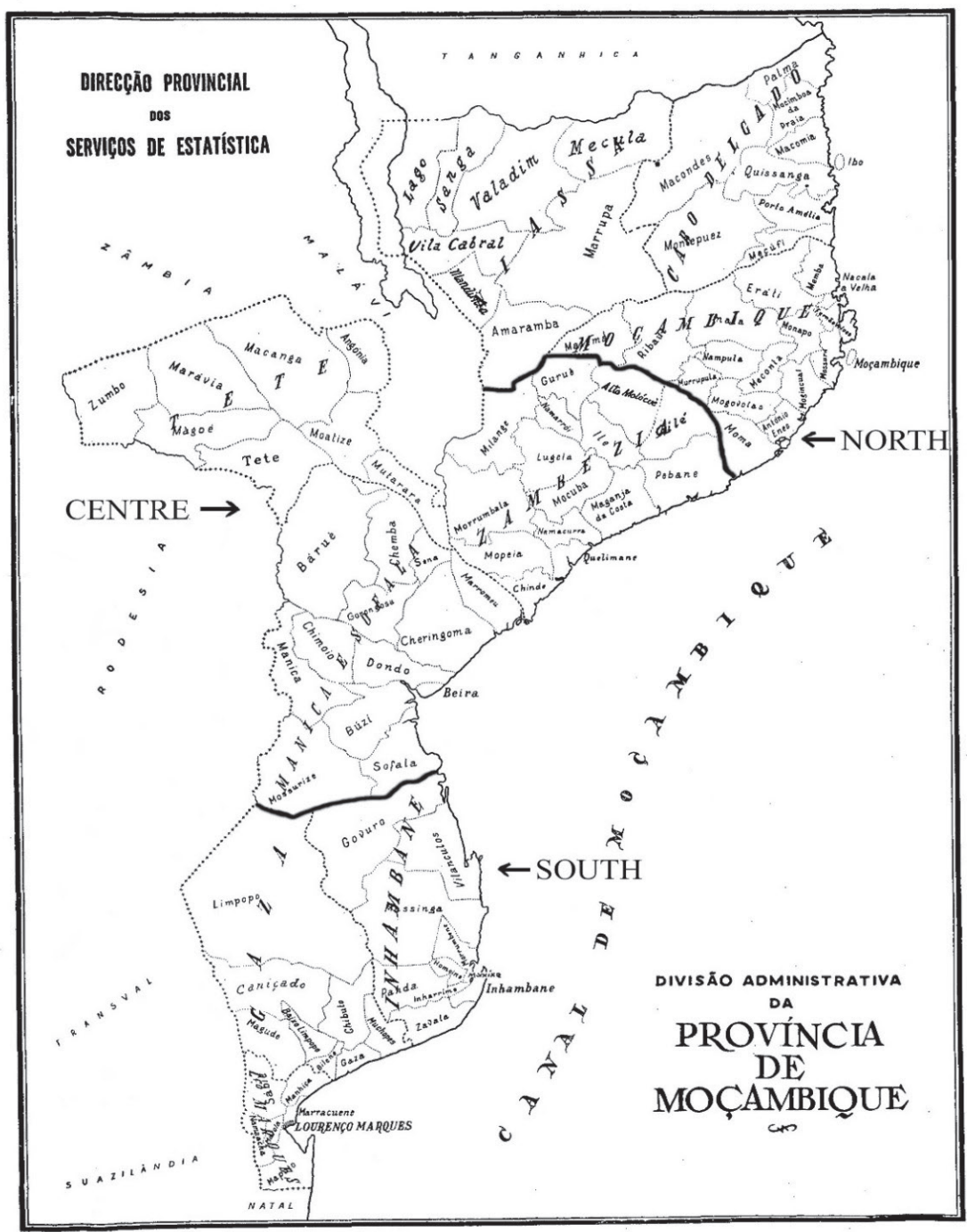

Source: Repartição Central de Estatística Geral (1963), Anuário Estatístico.

37 The Estado Novo was a corporatist and authoritarian regime, introduced by António de Oliveira Salazar in 1932 and followed by Caetano's governance from 1968 to 1974, when it was overthrown by the Carnation Revolution in Portugal. 
The role of concession companies in the economic integration of Mozambique has been vehemently debated, for instance by Neil-Tomlinson and Vail (1977). The former praised the role of the Mozambique Company as central in the country's economic activity. He justified labour extraction and forced cash crop production on the basis of difficult climatic conditions and low population as well as in terms of an optimum ratio of investment to profit (ibid, pp.283-285). In contrast, Vail criticized the role of the Mozambique Company and argued that it "failed to provide development and to stimulate a truly integrated local economy" (ibid, pp.285-286). In administrative terms, the division between colonial state and company rule was an impediment to the unification of the distinct zones of Mozambique.

For decades Mozambique was characterized by a dual-racial system of local governance similar to those existing elsewhere in Africa: the indigenato. The indigenato code was formally adopted in 1928 and was in place until 1962. It was based on previous arrangements of citizenship and governance, and it subordinated Mozambican subjects to tribal chiefs and Portuguese citizens to colonial administrators (Mamdani 1996). For the indigenes the indigenato meant that, first, they were forced to work (they had the "moral" obligation to do so) or alternatively produce agricultural surplus for the market; second, they had to pay taxes. If they could not fulfil their tax obligations, they could be recruited by colonial officials for forced labour. In that period local chiefs (regulos) and administrative assistants (cabos) were responsible for hut tax collection and forced labour recruitment ${ }^{38}$ and were paid by the colonial state through commissions (Isaacman and Isaacman 1983, p.29).

Portuguese colonial officials justified the institutionalization of coercive labour in Mozambique on the basis of the following argument: African industriousness had to be stimulated and development projects had to be promoted in order to raise the living standards of indigenous people. Forced labour came under the same regulation umbrella as wage labour. According to the Regulamento do Trabalho Indigena (1899), those "who do not fulfil voluntarily the obligation to work [...] will be compelled by the authorities to do so" (cited in Duffy 1959, pp. 155-156). Under effective occupation the argument of labour shortage became more prevalent. Because of large migration streams to foreign countries throughout the colonial period, demand for labour from the side of both the private and the public sectors was always higher than the available supply. Since neither the colonial state of Mozambique nor the

\footnotetext{
${ }^{38}$ In Angola, as elsewhere in Portuguese Africa, native chiefs were involved in the tax collection after the 1910s. In the 1920s they were often punished if they did not cooperate with the Portuguese administration. Also, in several cases chiefs became agents of resistance (Keese 2005, pp.120-122).
} 
companies based there were able to compete with the wages offered in South Africa, Portuguese colonial rule established various forms of forced labour. In 1926 it reintroduced forced labour (chibalo), based on the 1898 regulation, but enforced it much more systematically. The idea was to make the colonies the provider of raw materials and markets for the industry of Portugal.

In the late 1950s forced labour was banned, and there was a general shift in the metropole towards more developmental policies. It was mainly the international pressure to abandon forced labour - also as a requirement to join international organizations - as well as the rise of anti-colonial sentiments in the metropole that led to this political tide. Starting in 1953, six-year development plans fostered investments of $\$ 180$ million in Mozambique, at first in infrastructure and communication and finally in agriculture, education, and health, however benefiting mainly the white population (Penvenne et al. 2005, p.84). But the outbreak of the African independence movements in the 1960s made military investments a priority again.

\section{The way to gold: institutionalizing migration labour in the south}

In the vein of Samir Amin, the south of Mozambique (Inham bane, Gaza, and Lourenço Marques districts) functioned as a labour reserve for the surrounding gold mines and European farms. Since the first discoveries of diamonds in Kimberley (South Africa) in 1867, and especially of gold in the Witwatersrand in 1886, southern Mozambican migration to the mining centres had been crucial. The tradition of migration to South Africa has even earlier roots in the mid-nineteenth century, when sugar growers in Natal started to recruit labour in the Portuguese colony. Thus, migration from the south of Mozambique was clearly an early colonial phenomenon that the Portuguese colonial authorities used to make profit and foster fiscal capacity.

As Figure 3.1 shows, until 1930 on average 50,000 people per annum temporarily migrated from Mozambique (principally from the southern part) to the mines of Transvaal until 1930, and the numbers doubled until the late 1960s. Migration diminished in the 1970s when the Frelimo movement closed several recruitment centres operated by the Witwatersrand Native Labour Association (WNLA), and it remained low until 1984. The recorded numbers include both legal and illegal migration; the colonial office also kept records of "clandestine migration" (or non-recruited migrants), which usually accounted for around thirty per cent of the total. Until the mid-1970s Mozambique provided the largest share of workers to the mines 
of South Africa (First et al. 1998, p.204). ${ }^{39}$ Migration to Southern Rhodesia, also recorded in the statistical yearbooks and portrayed in Figure 3.1, was mainly transitory migration to South Africa. Since the border between Mozambique and South Africa was under tight control, clandestine migrants used a route that went through Southern Rhodesia. However, several Mozambicans also engaged in farm labour there, usually to save money to continue their route to South Africa, where wages were higher (Johnson 1990).

\section{Figure 3.1. Number of migrants from Mozambique to South Africa and Rhodesia,}

\section{2-1973}

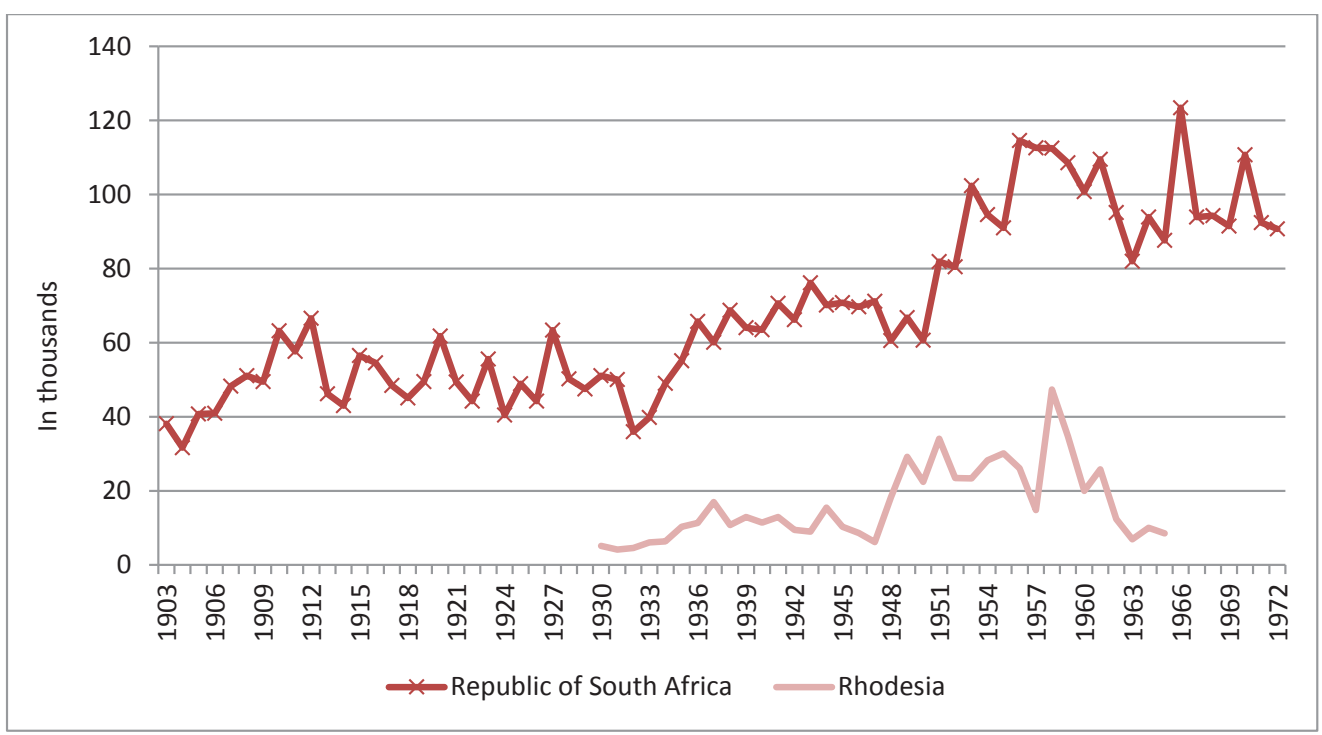

Sources: For the 1900s-1920s, Direcção dos Serviços dos Negócios Indígenas, Movimento da emigração, vol. 1 Cx 48, in Arquivo Historico de Moçambique (AHM); for the 1930s-1970s, Repartição Central de Estatística Geral, Anuários Estatísticos (Statistical Yearbooks).

Historians have argued that the large-scale exploitation of gold reserves in South Africa would never have been profitable without the mobilization of large numbers of unskilled and low-

\footnotetext{
${ }^{39}$ In 1904, Mozambican workers as a proportion of the total number of miners in South Africa was $66 \%$ and in 1920 it was $56 \%$. In 1936 it decreased to $28 \%$ but in 1956 it rose again to $55 \%$. Finally, by 1970 it had dropped to $28 \%$ owing to the increasing influence of the Frelimo independence movement, which criticized the huge migration streams from Mozambique and especially the surplus extraction on the part of the apartheid regime in South Africa.
} 
paid indigenous labourers from throughout southern Africa (Feinstein 2005). ${ }^{40}$ But it was not only the mining companies and the state of South Africa (increasingly interventionist and cooperating with the private sector) that profited from migration labour; the providing states too secured large revenues from the migration flows to the mines. In more recent times, in the 1990s, almost a third of Mozambique's GDP derived from migrant miners' wages (Crush et al. 1991, p.2). In the early colonial period, mining labourers belonged to the few who earned money in cash, and could therefore contribute to the fiscal revenue of the colonial state by paying direct taxes. Although rural households also profited from the remittances sent by the migrants, the high emigration streams certainly affected the rural areas of the southern districts of Mozambique, which were periodically deprived of the presence of able-bodied young men to help with the harvest (Van den Berg 1987). For instance, in Inhambane in the 1940s between twenty-six and thirty-one per cent of the male active population was away at any time of the year (Newitt 1995, p.501). A further negative consequence of migration may have been that it promoted forced labour practices in the southern part of Mozambique. Allina refers to forced labour as one of the economic and political consequences of labour shortage, created by labour migrating from Mozambique to South Africa and Rhodesia: "intense economic competition in southern Africa led Portugal to rely on forced labour to develop and protect her claims to her colonies" (Allina 1997, p.12). ${ }^{41}$

The Portuguese colonial government soon realized that it had to take control of the migration streams in order to profit from them through taxation and other fees. It signed a long series of inter-state contracts with South Africa that strictly regulated the "export" of labour, starting in 1897 (First et al. 1998, pp. 18-19). On both sides of the border, control posts were

\footnotetext{
${ }^{40}$ In 1912 the Chamber of Mines granted the monopoly of recruiting to two organizations, allowing uniform recruiting policies and the control of wage levels: the Native Recruiting Corporation (NRC), which operated in South Africa, and the WNLA, operating elsewhere. Moreover, the recruitment system that was put in place allowed labour to be mobilized from ever more distant and poorer regions, where people would still work for the prevailing low wages.

${ }^{41}$ Penvenne (1995), on the other hand, considers forced labour practices in Mozambique as a cause of increasing migration and labour scarcity at a national level, since many indigenous people migrated legally or illegally to neighbouring countries in order to avoid the risk of being sentenced to forced labour in Mozambique. She presents shibalo (forced labour in southern Mozambique) as a push factor for both internal and external migration. First, it forced peasants out of their home region to work on plantations and in public works. Second, it diminished free wage labour opportunities and wages within Mozambique and encouraged external migration. Indeed, forced labour can be perceived either as a push factor for migration, from the perspective of indigenous people, or as the consequence of labour shortage caused by migration, from the perspective of colonial rule. In any case, it was a significant link in the "chain" of taxation-labour-monetization, especially in the northern and central zones of Mozambique, as we explain in the following subsections.
} 
set up to keep track of the migrant movements. In order to have better control of migration streams, a curatorship was established in Johannesburg, which could also legalize the situation of Mozambican clandestine migrants by issuing passports, so that mining companies could engage them.

In the Portuguese Labour Agreement with Transvaal of 1901, the Modus Vivendi, and essentially all subsequent agreements, the period of service of workers in the mines was set to twelve months and could be extended by a further six months (Jeeves 1985, p. 217). When the contract ended, the workers had to be sent back to Mozambique in order to spend their earnings at home. These agreements also granted monopolistic permission to recruit labour in Mozambique to the WNLA until 1965; later, three other recruitment organizations gained permission. Both governments set the salaries for the migrant workers. These were relatively low, due to the monopoly of labour recruitment granted to the WNLA by the Chamber of Mines of Transvaal and by the government of Mozambique.

Other terms of the agreement included the prohibition on recruiting above $22^{\circ}$ latitude (just below the frontier of the territory of the Mozambique Company) - except for a short time between 1908 and 1913 (First et al. 1998, p.21). Thus the WNLA recruited only in the three southern districts: Inham bane, Gaza, and Lourenço Marques. This lim itation was im posed by Mozambique to address the complaints of companies and settlers about scarcity of labour and the inability to compete with wages paid in South Africa. It did not prevent residents of the northern districts from travelling to the recruitment stations, but actually most migrants originated from the three southern districts. In the statistical yearbooks, between only ten and thirty per cent of those emigrating between 1929 and 1950 are listed not as leaving one of the three southern districts but as originating from an "unknown district" (see Appendix Figure A3.1). Figure 3.2 displays the proportion of migrants per 1,000 inhabitants from each of the three southern districts. Inhambane is almost consistently the district that sent most migrants to Transvaal relative to its population (between 30 and 80 per thousand inhabitants), followed by Gaza (with around 20 to 50 per thousand inhabitants), and Lourenço Marques (around 11 to 30 migrants per thousand inhabitants). 
Figure 3.2: Migrants from southern districts to Transvaal (South Africa), 1929-1951

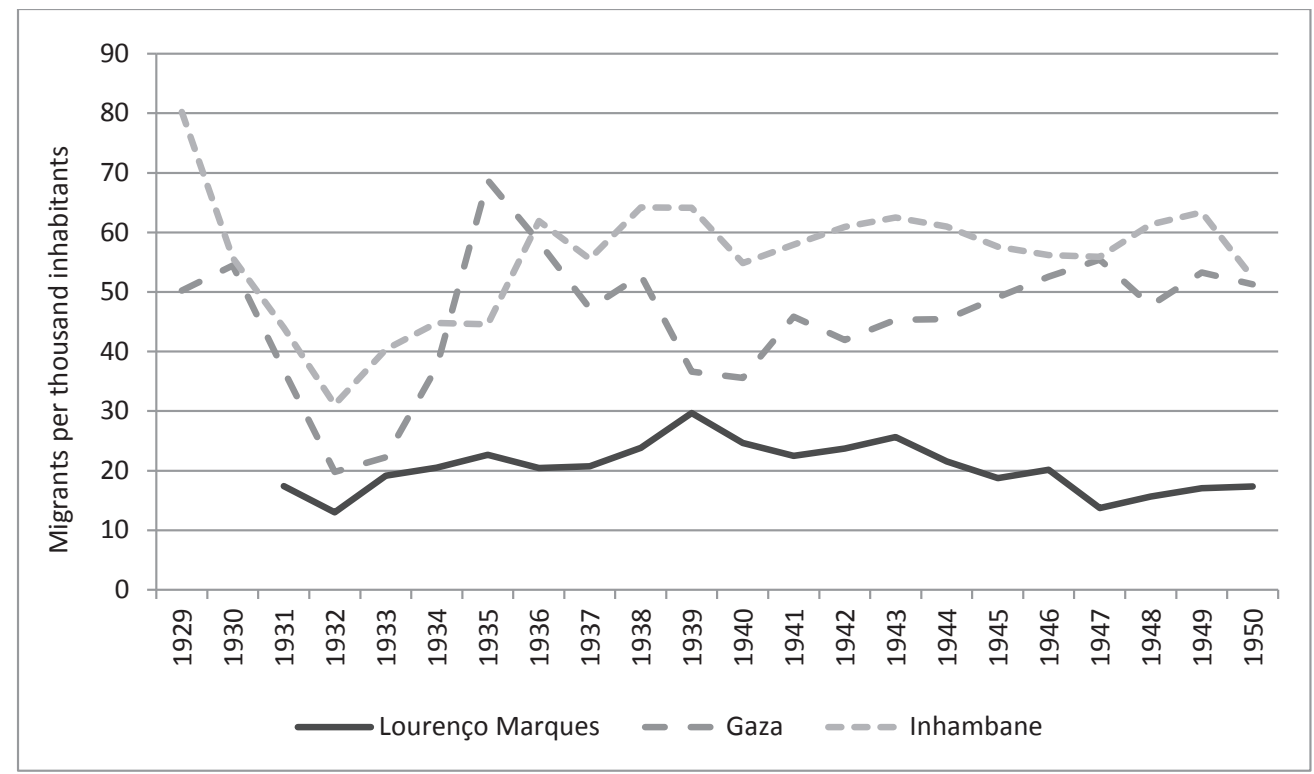

Sources: For the 1900s-1920s, Direcção dos Serviços dos Negócios Indígenas (Lourenço Marques, 1951), in AHM; for the 1930s-1970s, Repartição Central de Estatística Geral, Anuários Estatísticos (Statistical Yearbooks).

The Lusitanian colonial government charged recruitment licences as well as passport issuing fees to the recruiting organizations for each Mozambican employee. Furthermore, a migration tax was collected at the border with South Africa. Portuguese success in making profit from migration streams to South Africa, Southern Rhodesia, and São Tomé is reflected in the amount of revenue raised from migration, listed as such in the statistical yearbooks (this excludes indigenous taxes). The sources of revenue include licences for recruiting personnel; migration, passport, and registration taxes; reengagement fees; and other payments, which were largely raised in the curatorship of Transvaal; smaller amounts were collected in Southern Rhodesia and at the Ressano Garcia border post (Repartição Central de Estatística Geral 1941, p.120). To put it into perspective, in the 1940 s and 1950 s total revenue raised from migration represented around twenty per cent of total direct tax revenue (see Table 3.1). 
Table 3.1: Total revenue from migration as a share of total direct tax revenue, 1941-57

\begin{tabular}{|l|l|l|l|}
\hline & $\begin{array}{l}\text { Total revenue raised from } \\
\text { migration (to Transvaal, } \\
\text { Rhodesia, São Tomé) }\end{array}$ & $\begin{array}{l}\text { Average total direct tax } \\
\text { revenue }\end{array}$ & $\begin{array}{l}\text { Migrant tax / total } \\
\text { direct tax revenue }\end{array}$ \\
\hline $\begin{array}{l}\text { Average } \\
\text { for years }\end{array}$ & in constant 1954 escudos & $\%$ \\
\hline $1941-1945$ & $62,505,585$ & $245,590,527$ & 25 \\
\hline $1946-1950$ & $47,958,187$ & $258,505,152$ & 19 \\
\hline $1951-1955$ & $52,357,034$ & $273,647,258$ & 19 \\
\hline $1956-1957$ & $55,655,917$ & $294,507,807$ & 19 \\
\hline
\end{tabular}

Source: Repartição Central de Estatística Geral, Anuários Estatísticos (Statistical Yearbooks), various issues; price deflator: Valério (2001), Table 8.1.

To collect indigenous taxes from migrants working in the mines of Transvaal effectively, direct taxes were also paid at the Portuguese curatorship in Johannesburg and in Southern Rhodesia. The direct tax revenue collected outside Mozambique accounted for five to ten per cent of total direct tax revenue throughout most of the time under study (Repartição Central de Estatística Geral, 1926-1973). Another important advantage for the Portuguese government derived from the stipulation that a large share of the migrant workers' salary be deferred to the completion of their terms in the mines and paid directly after their return to their home country. ${ }^{42}$ It ensured that the workers returned to Mozambique and spent their earned cash at home, thereby contributing to the monetization of the economy. Given that the districts that sent migrants to South Africa became the most monetized areas, the largest share of the direct tax revenue of Mozambique could be paid by the population of this southern region.

As for the living conditions of migrant labourers in the mines and compounds, much has been written in a seminal work by Patrick Harries (1994), so these will not be discussed extensively here. Both during the transportation of migrant labourers from far-away regions to Transvaal and in the mines and compounds, mortality and morbidity were considerable. A

\footnotetext{
${ }^{42}$ In 1928 a new agreement was ratified by the Union of South Africa and Portugal: South Africa gained greater control over the Transvaal / Lourenço Marques railway line as well as over the port of Lourenço Marques, and the colonial state of Mozambique ensured that the system of deferred pay was made compulsory.
} 
racial labour regime that prevented indigenous people from entering skilled and semi-skilled jobs emerged for the first time in the mines (both Kimberley and Transvaal) and marked the beginning of the apartheid labour policies later applied to all industries in South Africa. As Appendix Figure A3.2 shows for 1930 to 1950, average indigenous migrant miners' wages decreased significantly in real terms throughout this time, as they did for the remainder of the twentieth century. ${ }^{43}$ However, wages were higher in the Rand gold mines compared with those paid for unskilled (and mostly forced) wage labour by the state and the private sector in Mozambique. And thus, migrating to the mines was probably the most appealing alternative for men living in rural areas, given the obligation to work and the pressure to earn cash wages imposed on the indigenous population through colonial taxation.

We can conclude that colonial rule in Mozambique invested in controlling and promoting a pre-existent migratory phenomenon, which represented a rich source of revenue, especially in the form of direct taxes. Furthermore, we can assume that the fact that the capital city was located in the south and that there was probably a larger concentration of colonial officials there facilitated control and tax collection in this area, compared with more remote areas with less official European presence.

Apart from functioning as a migrant labour pool, this zone experienced a boom in settler migration from Portugal in the 1940 s, due to the attempt of the colonial government to attract white population (Castelo 2007), which made the development of a European farm economy possible. As a result of successful state assistance to Portuguese settlers (O'Laughlin 2000 , p.10), the south became more competitive in terms of agricultural production and trade. Consequently, European farms became an additional source of employment for indigenous people wanting to gain cash wages.

\section{Centre: The land of concessions and forced labour}

The centre (Zambezia, Manica e Sofala, and Tete districts) fits the category of the "Africa of concessions". Traditionally, the prazo holders dominated part of this region and this institution was not completely abolished after the "effective occupation" (1890s) by Portugal, but most

\footnotetext{
${ }^{43}$ Our calculation of wages is based on the total amount that migrant labourers received in wages divided by the number of migrants, adjusted by the Consumer Price Index. Wages rose considerably again in the 1970s due to the need to attract unskilled labour because the migrant labour regime collapsed (Wilson 1976).
} 
of the land was leased to commercial companies. Thus, in the first few decades of colonial rule (up to 1942) the central districts were controlled by the (mostly foreign-owned) ${ }^{44}$ "Mozambique Company" (south of the Zambezi, district of Manica e Sofala) and the "Zambezia Company" (north of the Zambezi, districts of Zambezia and Tete).

The centre was governed in the interests of the concession companies. It was important for colonial rule to attract capital for plantations and foster "development", and therefore the administration provided cheap labour for these plantations. This was achieved by introducing the indigenous hut/poll tax, by forbidding payment in kind, and by introducing legislation forcing the population to work. The so-called indigenato institution forced the indigenous population to work almost throughout the colonial period (O’Laughlin 2002). Coercive labour either in public works or on plantations was remunerated, reaching minimum wage levels in the late colonial period. ${ }^{45}$ Cases of abuse, illegal extension of contracts, underpaid or withheld wages, and unjust treatment by local officials were not uncommon (Ross 1925).

The contract of the Mozambique Company with the Portuguese Crown in Manica e Sofala was prolonged until 1942 by the Republicans, ${ }^{46}$ but it was not then renewed by Salazar's regime, which aimed for budget balance and centralization. ${ }^{47}$ As the Governor of Manica e Sofala stated, the companies "did nothing to develop the potential wealth of this entire region, preferring to plunder it and alienate the natives" (Isaacman and Isaacman 1983, p. 37). Also, the Zambezia Company did little more than sublease its land to the initial occupiers and rulers of the land, thus the prazo holders managed to survive and keep their lands (Newitt 1995, p.678).

\footnotetext{
${ }^{44}$ For example, the Mozambique Company was established with a capital stock of about 5 million dollars obtained from financiers from Germany, the United Kingdom, and South Africa. Isaacman and Isaacman (1983) report that the firm was capitalized at 40,000 pounds, and that British and French capital quickly predominated.

${ }^{45}$ Penvenne stresses that the annual income of forced labourers would be equivalent to less than half of the annual income of free native labourers: "Ordinary municipal 'native' laborers earned 5,260\$00 a year, and municipal shibalo labor earned less than half that amount, 2,160\$00" (1995, p. 5). In the southern province of Sul do Save workers in agricultural enterprises and in the railway and street construction sectors received 150 escudos per month and in the industrial sector they received 180 escudos. In the province of Manica e Sofala the workers' monthly wage ranged from 60 to 130 escudos, while in central Zambezia it ranged from 60 to 90 escudos. Finally, in the poorest northern province of Niassa workers received 50 to 90 escudos for their services (Inspecção superior dos negocios indigenas 1951).

46 The First Portuguese Republic lasted sixteen years, from the fall of the constitutional monarchy in 1911 to the coup d'état of 1926 that led to the Estado Novo regime of Salazar.

${ }^{47}$ The contract stipulated that only 7.5 per cent of the profit had to be granted to the colonial state (Allina 2012).
} 
In the last few years of the concession companies, the metropole allowed smaller private companies to operate in the region and produce cash crops (sugar, tea, and cotton). Sena Sugar Estates Limited became the colony's largest producer and exporter. However, due to the rising demand for cotton from the metropolitan textile industry, Portugal introduced forced cotton cropping in certain zones of Mozambique in 1926, the same year as the military coup that overthrew the Republican government (Isaacman 1992). In Zambezia this was done by means of concessions to small private companies. In 1938 the Cotton Export Board was established to supervise the cotton industry in the colony. According to Vail and White (1978, p.249), the production and export of cotton in sufficient quantities succeeded in Zambezia thanks to the ruthless imposition of forced labour regulation from the 1940s. After insistent lobbying by the companies, the colonial authorities chose not to offer the carrot of paying higher prices to producers; instead they used the stick of coercion (ibid, p.251).

High labour scarcity, due to labour migration and rising competition between the companies in the region, led to repressive labour laws and extended use of coercive labour (Head 1978). As mentioned earlier, all adult males were obliged to work. If they cultivated the land, but did not sell their produce to the market and were not elsewhere employed on private plantations or infrastructure projects, they could be apprehended by the local authorities and used as forced labour. In early legislation (1909 and 1912), the contract period for forced labour could not exceed two years (Allina 1997, p.14). Eventually, labourers had to offer their services for a period of three to six months each time, and received their full pay only at the end of the contract. In 1942 this system "was formally re-introduced in Mozambique by Circular 818/D7", issued by the general governor of the colony, stating that vadios (vagrants) could expect to be arrested by the administrators and forced to work for a colonial enterprise. (Newitt and Tornimbeni 2008, p.717).

\section{"Mother of poverty": ${ }^{48}$ peasantry and cotton in the north}

The north (Cabo Delgado, Niassa, and Moçam bique districts) was traditionally a peasant based economy organized mainly by indigenous people, with trade bonds with British Nyasaland and German Tanganyika (today Malawi and Tanzania). Between 1891 and 1929, the northern region was not fully controlled by the colonial state. Most inhabitants were

\footnotetext{
${ }^{48}$ The phrase "cotton is the mother of poverty" was introduced by Isaacman et a. (1980).
} 
engaged in subsistence agriculture. In parallel, the British-owned Niassa Company was active in part of the territory and was allowed to force the indigenes to work on plantations and on infrastructure projects, as well as to pay the hut taxes that kept them indebted. This system enabled the Niassa Company to prevent the peasants from growing their own crops for sale and thus compete with the company's own production. However, the results in terms of production surplus and employment proved to be poor in this area, which is why the concession of the Niassa Company was not renewed by Portugal in 1929.

The north was densely populated compared with the centre and the south, but this potential tax source remained untapped throughout the colonial period. The hut tax rate in the north was half of the rate paid in the south, but even so peasants could not afford it. In the 1920s tax revenue collection progressed, but it soon stagnated again, mainly due to the world economic crisis (1929-1931). During the depression, fiscal tension rose tremendously: the number of hut tax debtors increased fivefold. However, the "problem of Niassa" predated the crisis. The tax burden in the northern districts was high for the indigenous peasants, since they did not produce sufficient surplus to sell to the market and thus generate income in cash. The difficulty was greatest in the district of Moçam bique, where the indigenous tax was raised "per capita", unlike the "hut" tax (Santos 2007b, p.5).

Insufficient food production due to unsuitable soils, lack of infrastructure (access to markets), and delayed payment of low wages by the Niassa Company were impediments that led to low monetization and tax revenue. In the $1930 \mathrm{~s}$, the local colonial administration responded in two ways: first, the circunscrição officials ${ }^{49}$ in Niassa started to under-register taxpayers to hide the poor performance in raising taxes; second, the law allowed fiscal debts to be paid in kind or in labour (Santos 2007b, p.7).

In the period 1938-1961 (under the metropolitan governance of Salazar), colonial policy severely reduced the autonomy of rural producers. In the late 1930s, the Colonial Cotton Board defined cotton zones whose inhabitants were forced to cultivate the crop, diverting labour from food cultivation. It signed agreements with twelve firms that gained power over half the colony (three districts of the north, plus Zambezia in the centre) (Isaacman 1992, p.493). The population of the cotton zones was obliged to sell their produce to the cotton companies at below-market prices; the companies in turn processed the raw cotton in their ginneries and exported the cheap produce to Portugal. Since Portuguese presence was limited

\footnotetext{
${ }^{49}$ Circunscrição is an administrative unit smaller than the "distrito" and bigger than the "posto".
} 
in these areas, the assistance of local chiefs was necessary to effectively implement the cotton regime (ibid, p.495). ${ }^{50}$

Figure 3.3 shows the production of raw cotton per district. Production took off in 1940 after the introduction of forced cropping and it remained stable until 1961 (except for a severe drop in 1956 due to an extreme weather shock) (Bravo 1963, p. 181). The district of Moçam bique was the largest producer of cotton, followed by Zam bezia.

Figure 3.3: Production of raw cotton by indigenes per district in Mozambique, 1939-62

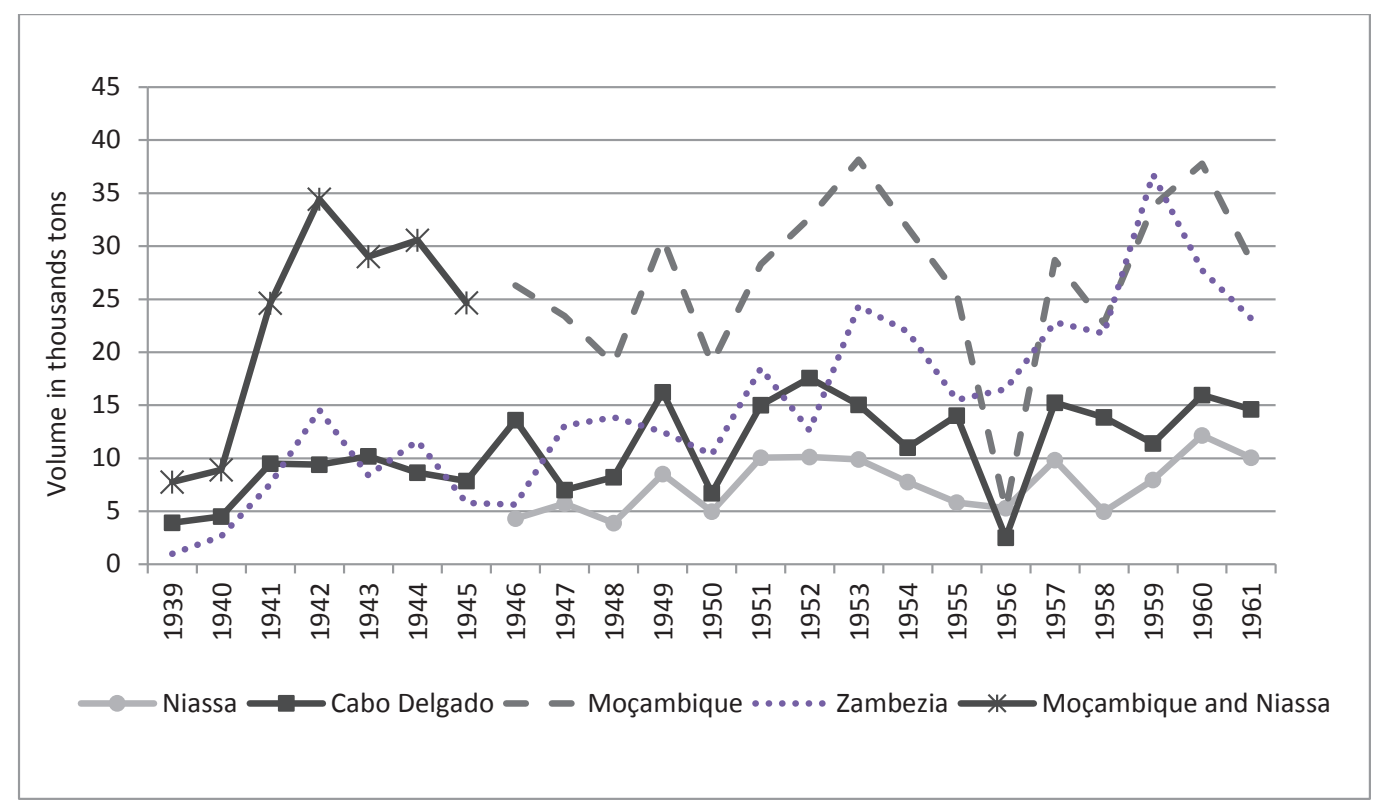

Source: Bravo (1963, pp. 136-139). Note: Until 1945 Moçambique district was part of a broader administrative unit, including Niassa district. From 1945 onwards Moçambique was a separate unit.

This system resulted in growing hostility on the part of peasants towards the colonial state. According to Isaacman, the low output and "the artificially depressed prices set by the state left many rural households impoverished" (Isaacman 1992, p.498) The average income of the cotton producers (one dollar for a whole crop) did not suffice even to allow them to pay their

\footnotetext{
${ }^{50}$ The Cotton Board defined zones where peasants could be forced to cultivate cotton; determined who was obliged to participate; fixed mandatory dates and times when rural communities had to plant, seed, and harvest their cotton crop; defined the various qualities of cotton; and finally, it helped to set the price paid to the peasants by the concessionary company.
} 
taxes. Since yields and prices were low, several peasants withdrew from cotton cultivation to focus on food production. However, in the early 1940s, officials further reduced the autonomy of peasants and imposed an extremely tough and controlling system of work obligations, without substantially raising prices. In short, the colonial cotton regime intensified the dynamics of impoverishment that were already present in this region.

\subsection{Persistence in tax inequality: Empirical results}

\section{Taxation in the three zones}

This section presents an empirical assessment of the differences in taxation between the three regions of Mozambique. We collected data on public revenue on an annual basis from 1930 until the end of the colonial period in 1973 from the "public administration" section of the statistical yearbooks and national accounts of the colony of Mozambique, found at the Instituto Nacional de Estatística in Lisbon. For the analysis, we chose to focus on direct taxes, because these are more difficult for the state to collect, and are therefore generally associated with greater state capacity, whereas indirect taxes, mainly derived from trade, are an easier source of extraction (Herbst 2000). Furthermore, direct taxation is more closely linked to indigenous labour policies and practices (as explained above) than taxing imports and exports. As mentioned earlier, hut and poll taxes constituted a relatively high share of total state revenue during colonial times in Mozambique, given that trade was relatively unimportant. Figure 3.4 shows that direct taxation contributed around fifty per cent of the value of total state revenue in the period under study (the corresponding figure in the 1940s was around sixty per cent, falling to around forty per cent in the 1950 s, before rising again to fifty per cent and then sixty per cent again in the 1960 s and 1970 s respectively). ${ }^{51}$

\footnotetext{
${ }^{51}$ As figure 3.4 shows, the total tax revenue increased fivefold between 1941 and 1973, and the sharpest rise occurred in the last thirteen years, from 1 billion to almost 1.8 billion escudos. The reasons could be various, including the larger military expenses during the independence war (1964 to 1974).
} 
Figure 3.4: Total state revenue and direct tax revenue in Mozambique, 1941-1973

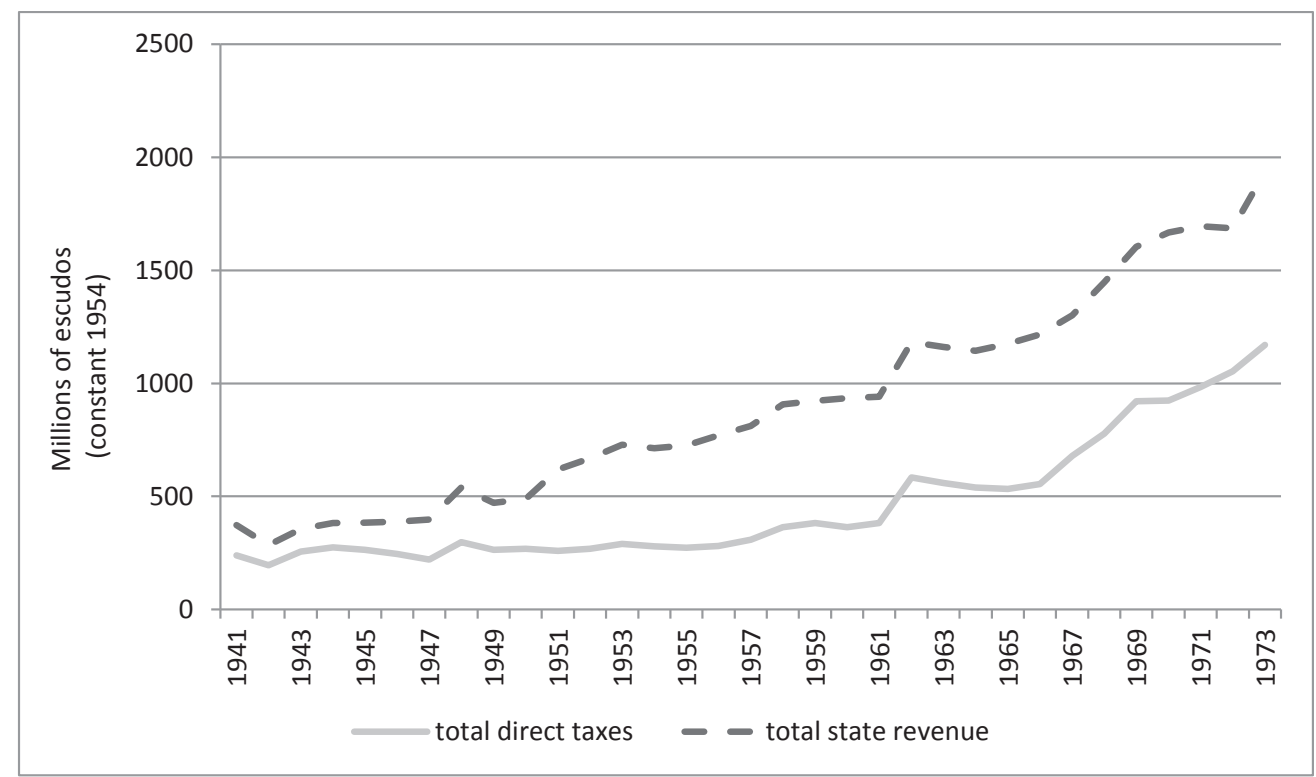

Sources: Repartição Central de Estatística Geral, Anuários Estatísticos (Statistical Yearbooks); Price deflator: Valério (2001), Table 8.1.

We reconstruct real direct taxes per capita for the nine districts of Mozambique by dividing total direct tax revenue (eighty per cent of which was accounted for by indigenous taxes until $1961)^{52}$ by the total population ${ }^{53}$ of the corresponding district, and deflating the value by the consumer price index in Portuguese escudos, the currency in which the tax revenues are recorded (Valério 2001, pp.661-662). For one of the nine districts, Manica e Sofala, information appears in the statistical yearbooks only from 1943 onwards (until then this district was under the rule of the Mozambique Company, which enjoyed a high degree of autonomy and kept separate records). Figure 3.5 displays total real direct tax revenue per capita in the three zones between 1930 and 1973. It shows that tax revenue per capita differed strongly between the north, the centre, and the south, and the order was highly persistent over time.

\footnotetext{
${ }^{52}$ European settlers paid direct taxes on their activities and assets (professional or property taxes) but did not pay personal income tax. However, after 1961 the indigenato system (informal colour bar) was ended and the indigenous tax was transformed into personal income tax, which also applied to the white population. This is probably why we see a sudden rise in total direct tax revenue in the 1960s.

${ }^{53}$ Population data are interpolated between censuses since censuses were carried out only every five or ten years.
} 
Figure 3.5: Real direct tax revenue per capita by zone in Mozambique, 1930-1973

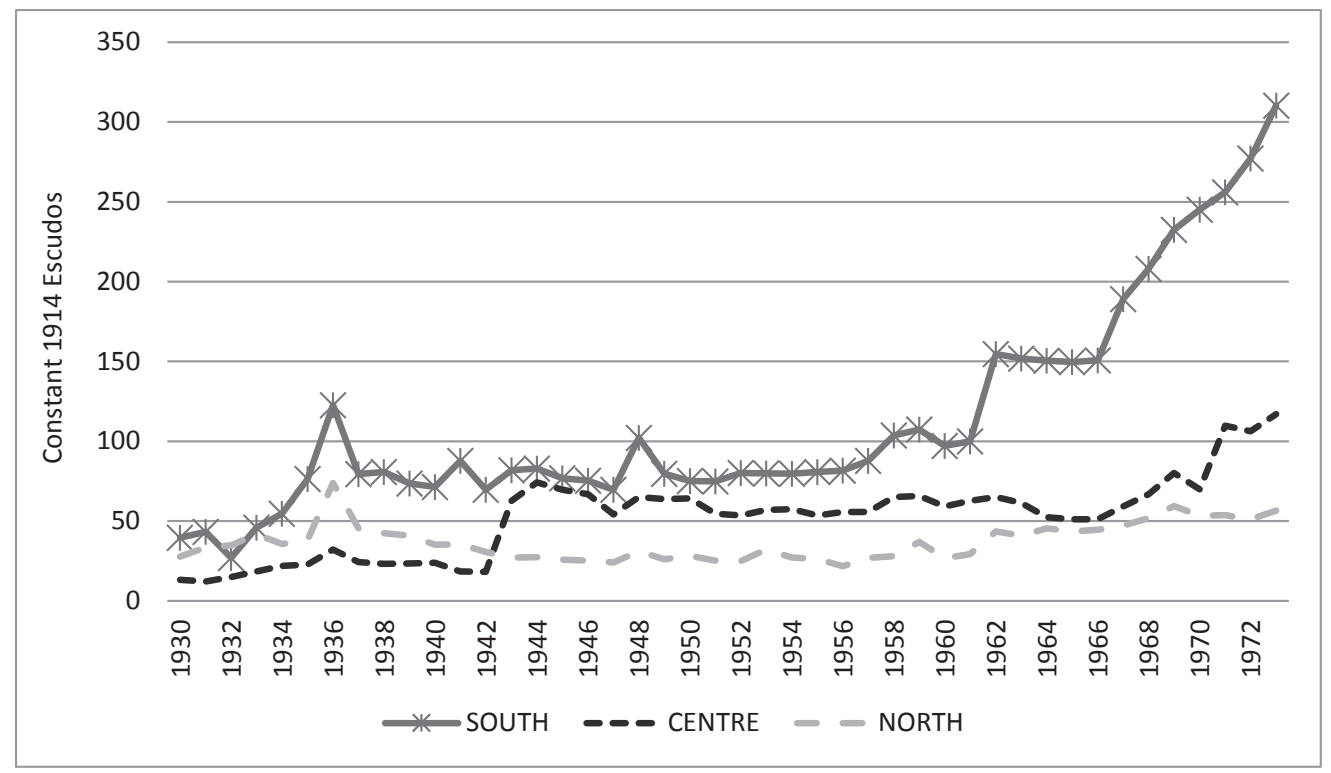

Sources: Direct tax revenue and population: Repartição Central de Estatística Geral, Anuários Estatísticos (Statistical Yearbooks), various issues 1930-1973²4; Price deflator: Valério (2001), Table 8.1 .

In the 1930s, average taxes in the south were three times the amount levied in the northern or central areas (excluding the district of Manica e Sofala, which was under concession company control until 1942). In this decade, the per capita tax revenue in the north was slightly higher than in the centre, whereas between the 1940s and 1970s this trend was reversed and per capita tax revenue in the centre (including Manica e Sofala) was on average double that in the northern area. ${ }^{55}$ In the last period, 1970 to 1973 , in the south direct tax revenue per capita was around six times that of the north.

\footnotetext{
${ }^{54}$ Similar information can be found in Direcção dos Serviços de Fazenda e Contabilidade. Contas de Geréncia e de Exercício (various issues).

${ }^{55}$ Santos argued that in the 1910s the administrative districts of the south provided - in total, not divided by population - ninety per cent of the hut tax revenue, collected directly by the government, while the centre and the north together did not exceed ten per cent of the total. See Santos (2012, p.2). The contribution of the northern and the central zones to total hut tax revenues in Mozambique gradually increased, and by the 1940s the shares of the three zones to indigenous tax revenue became almost equal (Santos 2007a, p. 201). However, these findings do not take account of the size of the population in each zone.
} 
Thus, the three regions not only contributed disproportionately to total direct tax revenue, per capita direct tax revenue was also much higher in the south throughout colonial times until independence, an indication that tax capacity was strongest in the south and weakest in the north. The differences in tax revenue shown in Figure 3.5 might derive from two things (or both at the same time): differences in the number of people whom colonial officials could tax, and variation in the tax rates levied per person. The first mainly has to do with demographic and geographic factors, the second with economic and commercial features. We have scattered evidence on native tax rates in the different zones derived from official correspondence. In 1948, the indigenous tax rate in the southern zone (in the districts of Inham bane, Gaza, and Lourenço Marques) was 250 escudos on an annual basis, while in the central district of Manica e Sofala the rate ranged between 100 and 210 escudos, depending on the circunscrição, and in the northern district of Niassa the rate ranged between 80 and 130 escudos (Inspecção superior dos negocios indigenas 1951).

\section{Explaining the differences in tax capacity}

We have shown that total direct tax revenue divided by the population was persistently higher in the southern zone of Mozambique than in the other two zones (north and centre). Our main argument is that the differences in the capacity of the state to extract taxes (and the effort put into it) derive mainly from the distinct local labour policies and practices.

However, in order to explain the differences in tax capacity between the three zones it is important to consider the factors that have conventionally been associated with the ability of the state to collect taxes, also termed "tax handles". We follow Stotsky and WoldeMariam (1997), Mkandawire (2010), ${ }^{56}$ Feger and Asafu-Adjaye (2014), and others in assessing quantifiable characteristics of the population and the economy, such as the dependency ratio (number of people aged 0 to 15 and above 65, divided by the total population), population density (population per square kilometre), urbanization (urban population as a proportion of the

\footnotetext{
${ }^{56}$ Mkandawire (2010) explores the difference between tax share and tax effort. Tax share is a standard measure of the share of tax in GDP, while tax effort is the relationship between actual and potential levels of taxation.
} 
total population), the ratio of Europeans to total population, the share of the population employed in agriculture, and the presence of an important port. ${ }^{57}$

The statistical yearbooks of Mozambique allow us to gather information concerning these characteristics at a district level. Table 3.2 assembles the above variables, and displays the mean values over the early (1930 to 1949) and late (1950 to 1973) colonial period for each of the three zones. For a more encompassing overview, Appendix Figure A3.3 displays the mean values for each district per decade. Our aim is to describe the differences between the three zones with regard to the "tax handles" that the literature has identified.

Table 3.2: Determinants of tax capacity by zone, 1930-1973

\begin{tabular}{|c|c|c|c|c|c|c|}
\hline & South & & Centre* & & North & \\
\hline & 1930-1949 & $1950-1973$ & 1930-1949 & $1950-1973$ & 1930-1949 & $1950-1973$ \\
\hline $\begin{array}{l}\text { Direct taxes per } \\
\text { capita, deflated }\end{array}$ & 72.03 & 146.82 & 36.20 & 66.45 & 35.09 & 38.54 \\
\hline $\begin{array}{l}\text { Population density } \\
\left(\text { per } \mathrm{km}^{2}\right)\end{array}$ & 8.78 & 16.41 & 5.32 & 8.43 & 7.46 & 9.40 \\
\hline $\begin{array}{l}\text { Urbanization } \\
(\text { year 1970) }\end{array}$ & 0.06 & 0.06 & 0.02 & 0.02 & 0.01 & 0.01 \\
\hline Dependency ratio & 0.75 & 0.75 & 0.97 & 0.92 & 0.82 & 0.83 \\
\hline $\begin{array}{l}\text { Proportion of whites } \\
\text { (1960) }\end{array}$ & 0.04 & 0.04 & 0.01 & 0.01 & 0.00 & 0.00 \\
\hline Agricultural share & 0.54 & 0.56 & 0.71 & 0.72 & 0.90 & 0.87 \\
\hline Important port & Yes & Yes & Yes & Yes & No & No \\
\hline Capital city & Yes & Yes & No & No & No & No \\
\hline $\begin{array}{l}\text { Migrants per } 1,000 \\
\text { inhabitants }\end{array}$ & 39.74 & 40.32 & 0.00 & 0.00 & 0.00 & 0.00 \\
\hline
\end{tabular}

*Data on Manica e Sofala as from 1943.

Source: Repartição Central de Estatística Geral, Anuários Estatísticos (Statistical Yearbooks), various issues 1930-1973.

\footnotetext{
${ }^{57}$ Income is one of the most important variables that explain fiscal capacity in the literature, but it is not possible for us to assess empirically the differences in income or in wages between the zones.

${ }^{58}$ One value over the whole period (data for 1970), also for number of whites as a proportion of total population (data for 1960).
} 
The age structure of the population (represented by the dependency ratio) might influence tax capacity because only the economically active population pays taxes, whereas our per capita direct tax variable includes the whole population in the denominator. A lower dependency ratio would mean that there are more people to be taxed in the population and fewer dependent people. Here the south as a region displays the lowest dependency ratio and thus better conditions for raising taxes. However, the north (with the lowest direct tax levels) displays lower dependency ratios than the centre.

A dense population has been claimed to facilitate tax collection. It allows tax administrators to exercise control over a larger number of people in a given area. In our case, the coastal districts have a higher population density than those inland. Tete and Niassa, the only landlocked districts, have the lowest density of population. This is probably due to the high migration to the neighbouring British colonies, Northern and Southern Rhodesia, which attracted labour by paying higher wages (Newitt 1995, pp. 482-514). The districts of Lourenço Marques (south), Moçam bique (north), and Zam bezia (centre)- in that order - are the most densely populated. As a region, the south has the highest population density, the centre the lowest.

Urbanization influences tax capacity in a similar vein as population density. Herbst holds that in African colonies the government often limited its power to the urban centres, where the majority of colonists resided, and ignored the peripheral areas (2000, p. 94). Since state capacity is closely linked to tax capacity, urbanization will probably enhance tax revenue per capita. The most urbanized zone in colonial Mozambique was the south, given that it includes the capital city of Lourenço Marques. The north had the lowest urbanization rate; none of the larger cities was located there. Urbanization thus clearly seems to affect tax capacity. Relatedly, centres of trade activity, such as important ports, can generate cash flows that facilitate the collection of monetary taxes. According to Mozambique's statistical yearbooks, the most im portant ports were Lourenço Marques in the south and Beira in the centre.

Furthermore, the number of Europeans as a proportion of a district's total population is a potential determinant of tax revenue according to Amin's theory, which holds that in settler economies the native population was pushed into wage labour by the levying of indigenous taxes. The white population itself was mostly exempted from paying direct taxes. The number of Europeans as a proportion of total population was lowest in the peasant-based north and highest in the south (mainly driven by Lourenço Marques), which contains the capital city and 
European plantation farms, especially from the 1940s. As already mentioned, European presence was a promoter of indigenous tax extraction.

A large share of the working population engaged in agriculture has also been claimed to have a negative impact on the tax capacity of the state because it includes subsistence farmers, who have difficulty in paying taxes in cash. Here, the north had the largest rate of agricultural employment, as we would expect, with ninety per cent of the working population engaged in this sector. We have already argued that the poor peasant-based north offered the worst conditions to extract taxes. Instead, as mentioned above, the south was home to large numbers of men employed in mining and possibly in services in the capital, which provided the state with more opportunities to collect direct taxes.

We also include in Table 3.2 the migrants-per-thousand-inhabitants variable. It takes the value zero for the north and the centre, since emigration was illegal there (and thus, only recorded as "from an unknown district"), and around forty per thousand for the south. For our argumentation, the large temporary migration to South Africa and to a lesser extent to Southern Rhodesia is very important in explaining the differences in tax capacity. Furthermore, we know from the literature that especially in the centre of the colony, where the concessionary companies operated, and also in the settler-dominated areas of the south, forced labour was common practice. However, it is unfortunately impossible to quantify forced labour in a consistent manner on an annual basis, since numbers of people recruited by force do not appear separately in the labour statistics and we found only poor and scattered information in classified reports or correspondence. Even if we could find approximate numbers of labourers employed in public works and on the colony's plantations, we would not be able to have this information per district.

In this section, we empirically showed the persistence of the unequal tax contribution of the three zones. We also analysed the differences between the regions with respect to geographic, demographic, and economic characteristics that are generally acknowledged to influence tax capacity. Variables affecting or capturing labour practices (Europeans as a proportion of the population, engagement in agriculture, urbanization, and emigration) clearly affected tax capacity. The question why the Portuguese administration failed to unify the fiscal and labour systems will be discussed below. 


\subsection{Colonial state formation without integration}

Why did Portugal fail to unify the three zones? First, the initial conditions, including geography as well as socio-economic and political institutions, played a crucial role in shaping different tax and labour patterns. Exogenous shocks, such as the discovery of gold in Transvaal, intensified migration streams from the south of Mozambique to the mines and further disconnected this area from the rest of the territory.

Second, Portugal was an economically disadvantaged imperial power compared with Britain or France. From early colonization up to the Depression (1930s), both Portugal and its African territories performed poorly in terms of budget balance. In order to limit the deficit and public expenses on colonial administration, the military, and infrastructure, the metropole either relied on concession companies and local chiefs or passed budget-tightening measures and stopped providing loans to the colonies (see chapter 2). In a way, following the example of Britain, Portugal relied on a system of indirect colonial rule, for pragmatic and economic reasons rather than for ideological purposes. Also, under Salazar's New State regime the metropole adopted restrictive fiscal policies that did not permit substantial public investment in the local development of the colonies. On the one hand, under the authoritarian regime Portugal aimed to exercise tight control over its colonies - for example, by ending the concessions of companies. On the other hand, Mozambique's colonial government continued delegating administrative tasks such as tax collection to native authorities, while smaller companies took over agriculture and infrastructure development projects. The colonial state was incapable of fully controlling the implementation of those activities, since budget problems forced it to rely on various non-state actors. The limited degree of centralization, despite the repressive character of the state, severely hampered the unification of the colony.

Overall, Portuguese colonial policies and practices were responses to the dynamics already in place in the region of Mozambique rather than proactive strategies to build solid fiscal and labour institutions in the colony. Eventually, this led to state formation without integration. There are, however, two points that Portuguese colonial rule could have altered regarding its fiscal and labour policies in order to reduce socio-economic inequality in the territory, but it chose not to make that effort.

First, from the 1930s onwards, during Salazar's era, Portugal did not comply with the international labour standards of that period. It did not ratify the ILO agreements and did not put an end to forced labour schemes until the 1960s, which undoubtedly harmed its 
"legitimization" as a colonial power" ${ }^{59}$ and drove the central and the northern zones of Mozambique into impoverishment and lack of monetization. Second, the Portuguese colonial state did not attempt to redistribute public income in favour of the rural areas, and especially the north of Mozambique, to diminish inequality between the zones. It is known from quantitative evidence that in the early colonial era most of the tax revenue was invested in security (see chapter 4) and administration, while in the post-1940s era infrastructure investments took off (see chapter 5), however almost exclusively in the cities and ports of the central and southern zone, such as Lourenço Marques and Beira. This way, Portuguese colonial rule contributed to the further widening of the gap between Mozambique's north and south.

\subsection{Conclusions}

We have shown that in terms of taxation and labour practices Mozambique consisted of three different zones (north, centre, and south), which fit the categorization of Samir Amin into "regions of colonial influence". Different labour systems have operated in the three geographic zones since early colonization, and these differences were maintained and exploited under colonial rule, also for the purpose of tax collection.

The empirical analysis demonstrated that the south, which operated as a labour reserve for the mines of South Africa, had significantly higher tax capacity than the peasant and concession economies in the north and centre, and this pattern persisted over time. Variables affecting or capturing labour practices (the share of Europeans in the population, engagement in agriculture, urbanization, and migration) were shown to be correlated with tax capacity, as expected.

We argued that the causes of the lack of integration in the process of colonial state formation in Mozambique are related both to local socio-economic conditions, including labour practices, and to metropolitan identity (Portugal as a weak imperial power in economic terms). Colonial rule did not considerably alter the conditions underlying fiscal inequality between the three zones. Instead, the colonial policies and practices concerning administration, taxation, and most importantly labour, reinforced the regional differences. Over the early decades (1890s1930s), the colonial state delegated administrative tasks to concession companies in central and

\footnotetext{
${ }^{59}$ For instance, repressive policies and practices such as forced labour were used by other colonial powers or by the state and companies in South Africa as an argument to deny Mozambique access to credit markets (Vail and White 1978, p. 242).
} 
northern Mozambique and until as late as 1960 used forced labour schemes, while in southern Mozambique it institutionalized labour migration to the mines in South Africa and taxed migrant incomes. Either by extracting revenue or saving expenditure, Portuguese rule exploited the existing patterns and failed to improve labour conditions for the indigenous people and to regionally redistribute public income.

Nowadays Mozambique is considered a failed state. Our research has important implications for the understanding of state formation and fiscal capacity-building in colonial and even post-colonial Africa, given that fiscal systems are highly path dependent and integration is a crucial component of state stabilization. For instance, in the post-colonial era migrant workers' wages still contributed significantly to the Mozambican economy. 


\section{Appendix}

Figure A3.1: Number of migrants to South Africa by district of origin, 1929-1950

\begin{tabular}{|c|c|c|c|c|c|c|c|c|c|}
\hline & Total num & ers & & & & Per 1,000 & habitan & & \\
\hline Year & $\begin{array}{l}\text { Lourenço } \\
\text { Marques }\end{array}$ & Gaza & Inhambane & $\begin{array}{l}\text { Unknown } \\
\text { district }\end{array}$ & Total & $\begin{array}{l}\text { Lourenço } \\
\text { Marques }\end{array}$ & Gaza & Inhambane & $\begin{array}{l}\text { Unknown } \\
\text { district }\end{array}$ \\
\hline 1929 & 2,915 & 16,265 & 19,629 & 8,645 & 47,454 & 22.1 & 50.2 & 73.0 & $\mathrm{n} / \mathrm{d}$ \\
\hline 1930 & 3,089 & 16,270 & 18,329 & 13,345 & 51,033 & & 54.4 & 55.7 & $\mathrm{n} / \mathrm{d}$ \\
\hline 1931 & 3,135 & 13,446 & 15,183 & 18,279 & 50,043 & 5.2 & 36.8 & 46.2 & $\mathrm{n} / \mathrm{d}$ \\
\hline 1932 & 2,420 & 10,390 & 10,936 & 12,210 & 35,956 & 12.4 & 19.8 & 31.1 & $\mathrm{n} / \mathrm{d}$ \\
\hline 1933 & 3,697 & 10,604 & 12,173 & 13,294 & 39,768 & 20.5 & 22.3 & 40.4 & $\mathrm{n} / \mathrm{d}$ \\
\hline 1934 & 3,690 & 15,174 & 14,731 & 15,358 & 48,953 & 19.8 & 37.4 & 44.8 & $\mathrm{n} / \mathrm{d}$ \\
\hline 1935 & 4,199 & 17,889 & 14,701 & 18,333 & 55,122 & 21.8 & 68.8 & 44.6 & $\mathrm{n} / \mathrm{d}$ \\
\hline 1936 & 4,358 & 21,379 & 21,852 & 18,132 & 65,721 & 24.2 & 58.4 & 66.3 & $\mathrm{n} / \mathrm{d}$ \\
\hline 1937 & 3,840 & 20,754 & 20,983 & 14,463 & 60,040 & 20.7 & 56.7 & 63.6 & $\mathrm{n} / \mathrm{d}$ \\
\hline 1938 & 4,928 & 25,504 & 25,946 & 12,388 & 68,766 & 23.1 & 69.7 & 78.7 & $\mathrm{n} / \mathrm{d}$ \\
\hline 1939 & 5,501 & 19,451 & 27,714 & 11,400 & 64,066 & 29.7 & 71.8 & 84.0 & $\mathrm{n} / \mathrm{d}$ \\
\hline 1940 & 6,019 & 22,584 & 24,096 & 10,743 & 63,442 & 41.4 & 35.5 & 54.9 & $\mathrm{n} / \mathrm{d}$ \\
\hline 1941 & 5,485 & 29,118 & 26,840 & 9,112 & 70,555 & 29.6 & 45.8 & 57.9 & $\mathrm{n} / \mathrm{d}$ \\
\hline 1942 & 5,763 & 26,540 & 28,356 & 5,510 & 66,169 & 23.6 & 41.9 & 61.1 & $\mathrm{n} / \mathrm{d}$ \\
\hline 1943 & 6,233 & 33,873 & 29,386 & 6,647 & 76,139 & 25.5 & 53.5 & 63.3 & $\mathrm{n} / \mathrm{d}$ \\
\hline 1944 & 5,238 & 28,770 & 28,954 & 7,131 & 70,093 & 21.6 & 45.4 & 62.4 & $\mathrm{n} / \mathrm{d}$ \\
\hline 1945 & 4,394 & 31,114 & 27,614 & 7,621 & 70,743 & 20.9 & 49.1 & 59.5 & $\mathrm{n} / \mathrm{d}$ \\
\hline 1946 & 4,936 & 29,695 & 27,003 & 8,000 & 69,634 & 20.3 & 52.6 & 56.2 & $\mathrm{n} / \mathrm{d}$ \\
\hline 1947 & 3,498 & 31,069 & 26,814 & 9,777 & 71,158 & 14.4 & 54.9 & 55.9 & $\mathrm{n} / \mathrm{d}$ \\
\hline 1948 & 4,149 & 26,943 & 29,473 & & 60,565 & 16.9 & 47.7 & 61.3 & $\mathrm{n} / \mathrm{d}$ \\
\hline 1949 & 4,703 & 30,078 & 31,985 & & 66,766 & 19.2 & 53.3 & 66.6 & $\mathrm{n} / \mathrm{d}$ \\
\hline 1950 & 4,963 & 27,888 & 27,748 & & 60,609 & 20.3 & 51.3 & 57.7 & $\mathrm{n} / \mathrm{d}$ \\
\hline
\end{tabular}

Source: Repartição Central de Estatística Geral, Anuários Estatísticos de Moçambique (Statistical

Yearbooks), 1929-1950. 
Figure A3.2: Salaries of migrant workers in the mines, 1930-1951

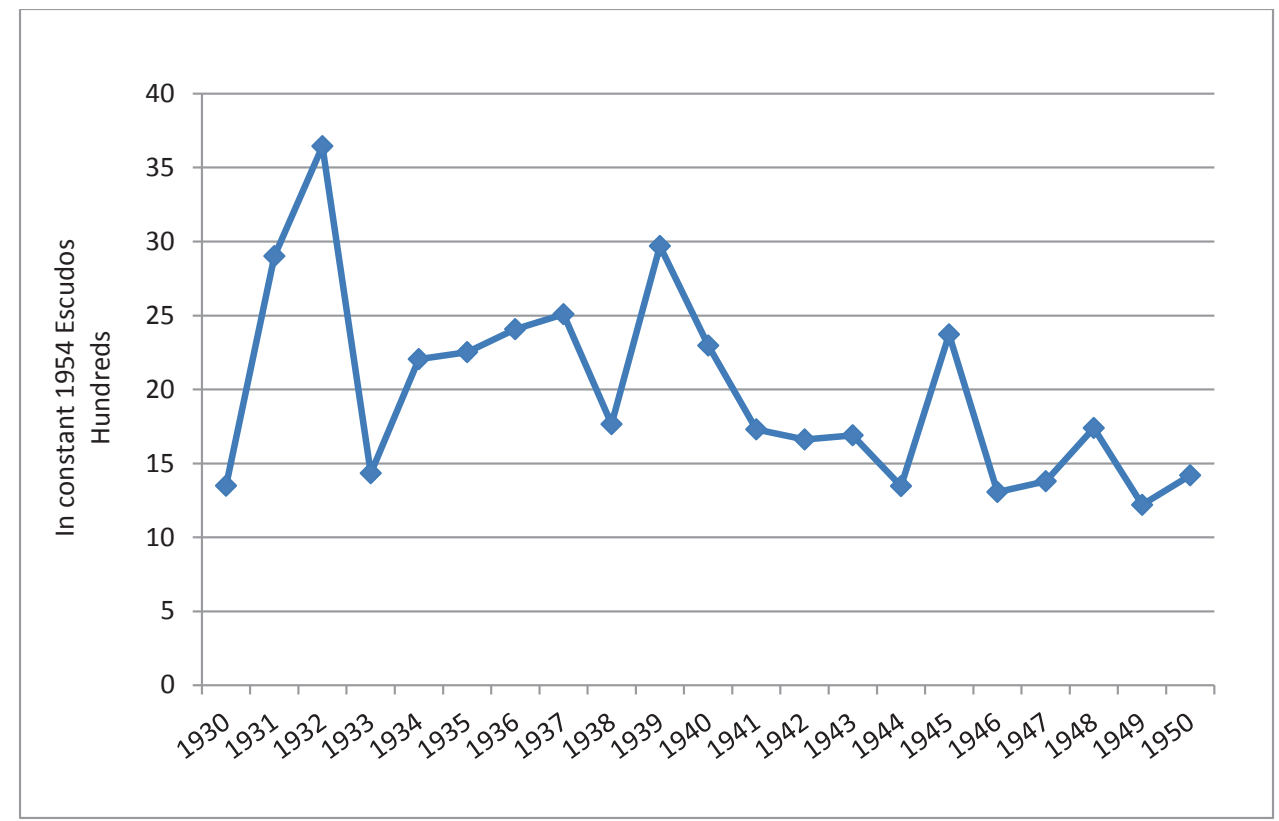

Source: Repartição Central de Estatística Geral, Anuários Estatísticos de Moçambique (Statistical Yearbooks); price deflator: Mitchell (2008), Table H1. 


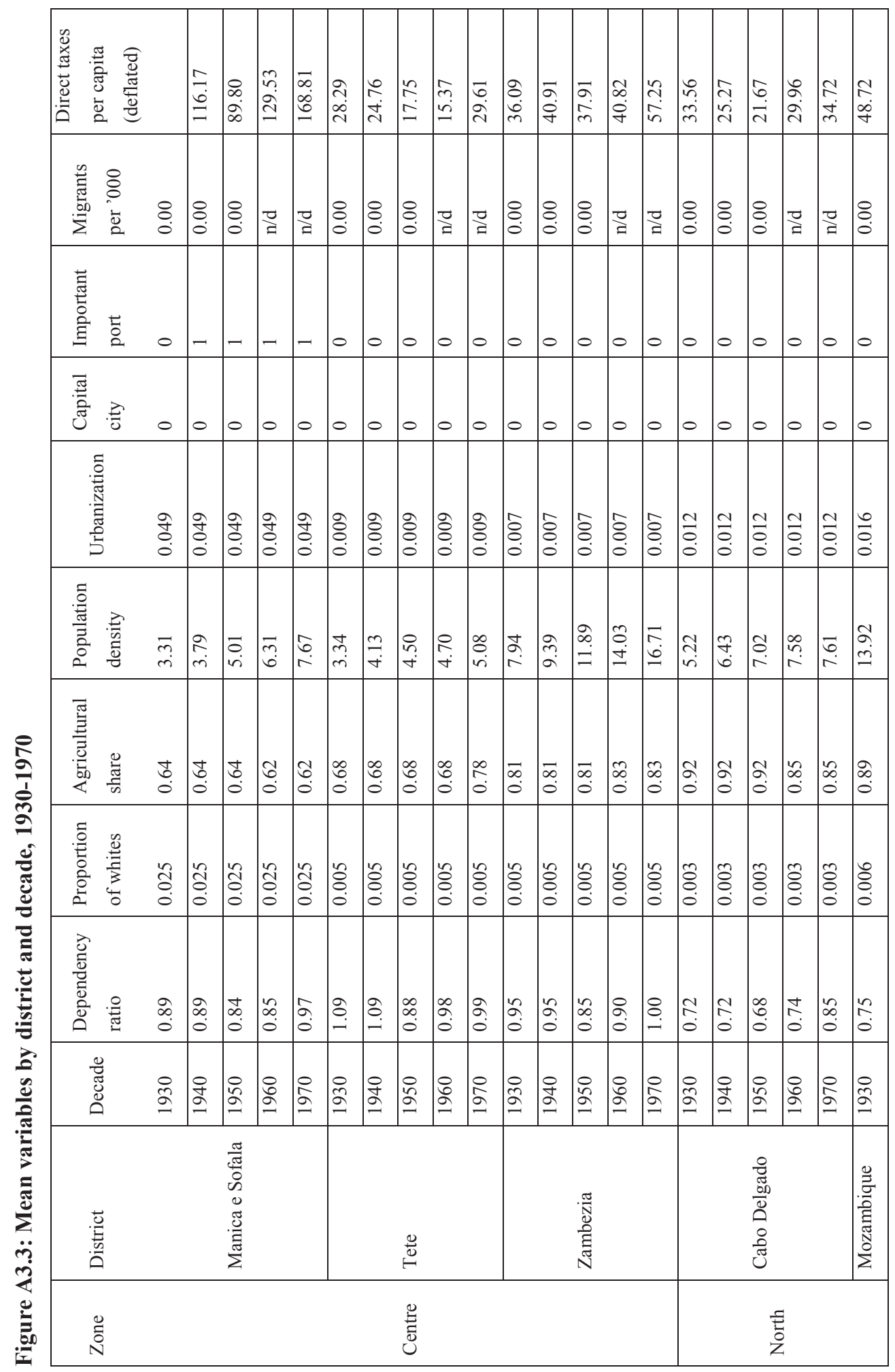




\begin{tabular}{|c|c|c|c|c|c|c|c|c|c|c|c|c|c|c|c|c|c|c|c|c|c|c|c|c|}
\hline $\begin{array}{l}\stackrel{p}{n} \\
m \\
m\end{array}$ & $\begin{array}{l}\hat{n} \\
\tilde{n} \\
m\end{array}$ & $\begin{array}{l}\infty \\
\stackrel{\infty}{n} \\
\text { n. }\end{array}$ & 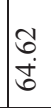 & $\begin{array}{l}\delta \\
\dot{\Xi} \\
\dot{\Xi}\end{array}$ & $\begin{array}{l}\text { वे } \\
\infty\end{array}$ & $\begin{array}{l}\vec{\sigma} \\
\ddot{\theta}\end{array}$ & $\hat{\bar{\alpha}}$ & $\begin{array}{l}\hat{2} \\
\infty \\
\infty\end{array}$ & s & & $\begin{array}{l}\underset{b}{\sigma} \\
\stackrel{f}{f}\end{array}$ & $\begin{array}{l}\tilde{n} \\
\tilde{\gamma}\end{array}$ & $\begin{array}{l}2 \\
\infty \\
\infty \\
\infty \\
m\end{array}$ & $\begin{array}{l}\infty \\
\infty \\
\check{f}\end{array}$ & $\mid \begin{array}{l}0 \\
0 \\
0 \\
0 \\
m\end{array}$ & $\begin{array}{l}\infty \\
n \\
\infty \\
n\end{array}$ & $\begin{array}{l}\hat{\sigma} \\
\tilde{m}\end{array}$ & $\begin{array}{l}\infty \\
\stackrel{\infty}{\cdot} \\
\vec{f}\end{array}$ & ले & $\left.\begin{array}{c}c \\
0 \\
\dot{0} \\
\end{array}\right)$ & 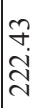 & 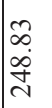 & $\begin{array}{l}\vec{\infty} \\
\stackrel{a}{\Gamma} \\
\stackrel{f}{f}\end{array}$ & 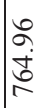 \\
\hline$\stackrel{8}{0}$ & $\stackrel{8}{0}$ & Ә & $\stackrel{\partial}{z}$ & $\stackrel{8}{0}$ & $\stackrel{8}{0}$ & $\stackrel{8}{\circ}$ & I & 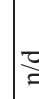 & $\begin{array}{l}\frac{1}{7} \\
7\end{array}$ & & 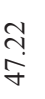 & $\stackrel{\hat{n}}{\grave{n}}$ & こ & ¿ & $\mid \begin{array}{l}0 \\
0 \\
0 \\
i \\
i n\end{array}$ & $\begin{array}{l}\infty \\
\infty \\
\infty \\
\infty\end{array}$ & $\mid \begin{array}{l}\infty \\
\\
i \\
i n\end{array}$ & $\stackrel{\Xi}{\beth}$ & $\stackrel{\Xi}{a}$ & $\begin{array}{c}\ddots \\
a \\
a\end{array}$ & 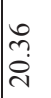 & ֶ̃ & تृ & $\stackrel{\Xi}{a}$ \\
\hline 0 & 0 & 0 & 0 & 0 & 0 & 0 & 0 & 0 & 0 & b & 0 & 0 & 0 & 0 & 0 & 0 & 0 & 0 & 0 & - & - & - & - & - \\
\hline 0 & 0 & 0 & 0 & 0 & 0 & 0 & 0 & o & 0 & 0 & 0 & 0 & 0 & 0 & 0 & 0 & 0 & 0 & 0 & - & - & - & - & - \\
\hline$\stackrel{0}{0}$ & $\stackrel{0}{0}$ & $\stackrel{0}{\circ}$ & $\begin{array}{l}0 \\
0 \\
0 \\
0\end{array}$ & ㄹ. & $\vec{\Xi}$ & $\vec{\sigma}$ & $\bar{\sigma}$ & $\bar{a}$ & $\begin{array}{l}\text { a } \\
\text { है } \\
0\end{array}$ & : & $\begin{array}{l}\infty \\
0 \\
0 \\
0 \\
0\end{array}$ & $\begin{array}{l}\infty \\
\tilde{\delta} \\
0 \\
0\end{array}$ & $\begin{array}{l}\infty \\
\tilde{\delta} \\
0 \\
0\end{array}$ & $\begin{array}{l}\infty \\
\tilde{\delta} \\
0 \\
0\end{array}$ & 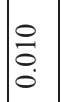 & $\begin{array}{l}0 \\
0 \\
0 \\
0\end{array}$ & $\mid \begin{array}{l}0 \\
0 \\
0 \\
0\end{array}$ & $\frac{0}{0}$ & $\mid \begin{array}{l}0 \\
0 \\
0 \\
0\end{array}$ & $\frac{m}{n}$ & $\stackrel{n}{\stackrel{n}{0}}$ & $\stackrel{n}{\stackrel{n}{0}}$ & $\frac{n}{n}$ & $\stackrel{n}{\frac{n}{0}}$ \\
\hline 8 & $\begin{array}{l}\infty \\
\infty \\
0 \\
0\end{array}$ & $\begin{array}{l}\vec{n} \\
\infty \\
-\end{array}$ & ڤn & - & 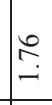 & $a$ & $\approx$ & $\infty$ & & 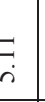 & $\stackrel{m}{r}$ & $\vec{r}$ & $\begin{array}{l}\infty \\
\infty \\
\infty \\
\infty\end{array}$ & f̊. & $\mid \begin{array}{l}0 \\
\text { in } \\
\text { in }\end{array}$ & $\stackrel{2}{\frac{1}{r}}$ & $\begin{array}{l}\mathscr{n} \\
\infty \\
\infty\end{array}$ & $\begin{array}{l}9 \\
\vdots \\
a \\
0\end{array}$ & 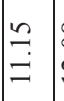 & $\mid$ & $\begin{array}{l}0 \\
n \\
n \\
n\end{array}$ & 守 & 离 & 7 \\
\hline
\end{tabular}

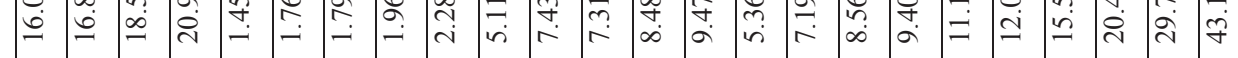

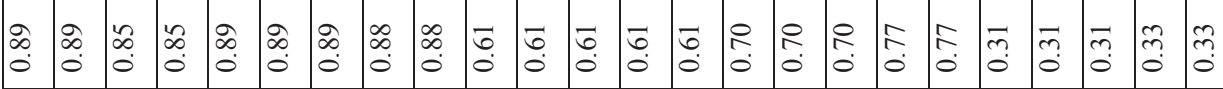

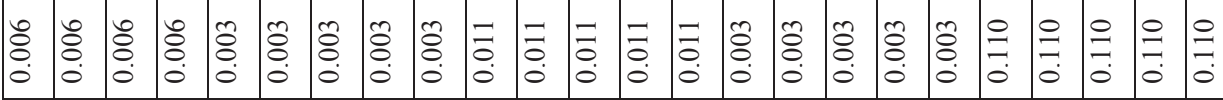

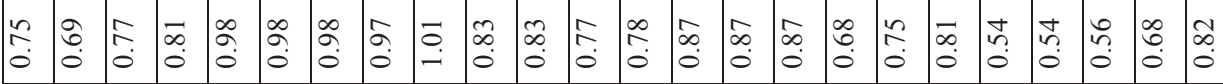

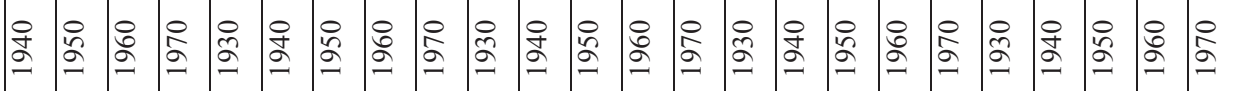

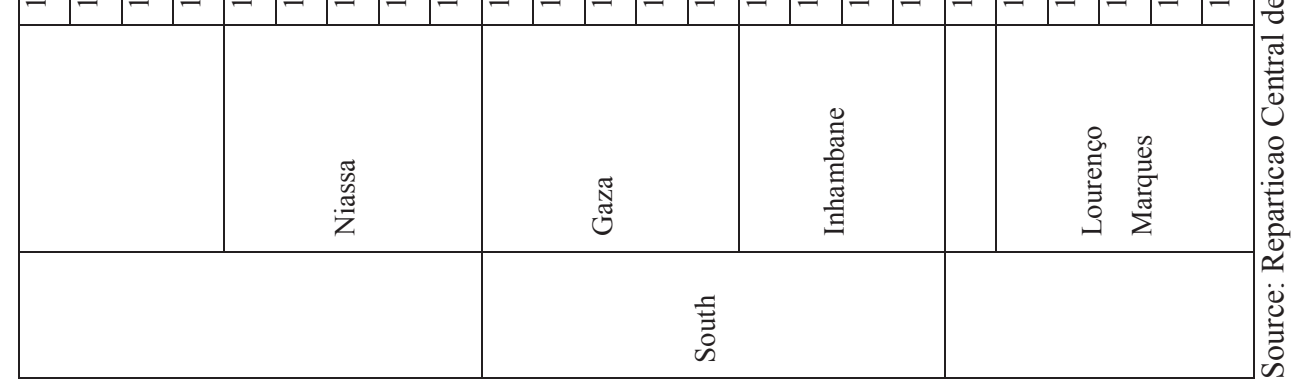




\title{
Chapter 4
}

\section{Imperialism of Jackals and Lions. The Militarization of Portuguese Africa in the British African mirror, 1850-1940 ${ }^{77}$}

\begin{abstract}
How did differences in geo-political power across European metropoles affect colonial state formation? We conduct an in-depth comparison of military capacity building in Portuguese and British Africa (1850-1940), hypothesizing that Portugal, a jackal, had to invest more in its colonial armies to secure internal order as well as to sustain its external borders against stronger powers such as Britain. We demonstrate that military expenses extracted much larger parts of the colonial state budget in Portuguese Africa and required considerable subsidies and loans from the metropole. We also show that armies were larger in Portuguese Africa and that recruitment practices entailed greater coercion. We argue that the colonial governments of Angola and Mozambique could not benefit from the economies of scale, the imperial crosssubsidies and the credible deterrence, which underpinned security policies in British Africa, and that this had long-term implications for state formation beyond the colonial era.
\end{abstract}

\footnotetext{
77 A version of this chapter has been submitted to the Journal of Global History as a co-authored paper by Kleoniki Alexopoulou and Ewout Frankema.
}

Acknowledgement note: We would like to thank Pim de Zwart, Elise van Nederveen Meerkerk and Nuno Valério. We also owe deep gratitude to Diogo Paiva for his assistance in data collection; to the participants of the 11th European Social Science History Conference in Valencia, Spain (April 2016); to the participants of the Annual Meeting of the African Economic History Network at Sussex University in Brighton, UK (October 2016); and of the World Economic History Congress in Boston, US (August 2018) for their insightful comments. Last but not least, we are grateful for the financial support provided by the Netherlands Organization for Scientific Research (NWO) as part of the VIDI project "Is Poverty Destiny? Exploring Long-Term Changes in African Living Standards in Global Perspective". The usual disclaimer applies. 


\subsection{Introduction}

There is a burgeoning literature at the crossroads of comparative politics, economic history and institutional economics which focusses on the comparative histories and legacies of European imperialism. One of the major debates in this literature juxtaposes the relative importance of distinct metropolitan visions and policies against the role of indigenous societies and local endowments in shaping the colonial state and economy (Young 1994, Sokoloff and Engerman 2000, North et al. 2000, Acemoglu et al. 2001, Easterly and Levine 2012, Frankema et al. 2016). With regards to sub-Saharan Africa, most of the comparative research has focussed on the differences between French and British 'styles' of colonial governance, including the distinction between direct and indirect rule (Crowder 1964), the varying design of legal and judicial systems (Hailey 1957, Lange 2009), varying approaches to labour coercion and industrial development (Cooper 1996, van Waijenburg 2018, Austin et al. 2017), varying policies regarding (missionary) education (Lloyd et al. 2000, Frankema 2012, Cogneau and Moradi 2014), and variations in administrative and fiscal systems (Gardner 2012, Frankema and van Waijenburg 2014, Dupraz et al. 2016).

The aim of this chapter is to highlight an aspect of metropolitan variation that has received too little attention: how did variation in geo-political power affect colonial state development, and especially its military and fiscal design? Among all the policy issues that colonial governments were facing, the following two were imperative and interdependent: to obtain a monopoly on the use of violence and to set up a reliable system of central revenue collection. Military control was a pre-condition for the expansion of the tax base, while tax revenues were needed to bear the costs of a sizeable army. How did colonial governments approach this challenge? What difference did the financial and military back-up of the metropole make? What were the implications of the different approaches to the security and revenue imperative for the long-run development of African states?

We explore these questions by investigating the case of Portuguese Africa in the mirror of British Africa. This comparative perspective has hardly ever been made in the literature, but it may offer deeper insights in the comparative politics of colonial state formation. To be sure, differences in the capacity to wield hard power have long been debated. Vladimir Lenin and Arturo Labriola already referred to Italian imperialism as respectively, beggar imperialism and imperialism of the poor (Michels 1914, p.95; Togliatti 2014). They argued that in the Scramble 
for Africa the 'weaker' powers (e.g. Italy, Belgium, Portugal) were puppets on a string pulled by the 'stronger' powers (e.g. Britain, France and Germany). Granting territory to lesser powers was a tried method to resolve tensions at the negotiation table, and allowed the major powers to focus on the prizes they prioritized. Clarence-Smith (1987, p. 94) referred to these weaker powers as the 'jackals' of imperialism, but argues that they had more bargaining power than Lenin and others thought they had. Clarence-Smith also criticized the term 'beggars' noting that the weaker metropoles were not necessarily economically backward (e.g. Belgium), and that stronger states were not necessarily economically advanced (e.g. Russia). Marini (1972, p.15) elaborated the concept of "sub-imperialism" to point out that even states such as China and Brazil who were subjected to European imperialism, were extending control over their own backyards at the same time. The Buganda Kingdom serves as a prominent African example of a polity that used its ties with the British to strengthen its regional position as an imperial power in the late $19^{\text {th }}$ century (Low 2009).

But while differences in metropolitan power have been central in narratives of the partition of Africa (Pakenham 1992; Wesseling 1996), the question what this meant for state formation after the borders were drawn has received much less attention. We adopt the metaphors of "jackals" and "lions" of imperialism to refer to the large variation in geo-political power of European metropoles and define "power" as the capacity to back up national and metropolitan interests by military means and other economic resources. Portuguese colonial governance has been known to be particularly violent and coercive because of its intensive use of forced labour - including forced army recruitment - its long and violent suppression of decolonization movements and its very low investments in welfare services such as health and education (see Wheeler 1969, Ball 2015, Madeira 2005, Cooper 2002). There is also a range of studies arguing that former British colonies benefitted from comparatively high welfare investments (Grier 1999, Lloyd et al. 2000, La Porta et al. 2008, Cogneau \& Moradi 2014). Some scholars have ascribed the more 'benign' and 'developmental' features of British imperialism in terms of a cultural and even moral distinctiveness (North et al. 2000, Ferguson 2002). Yet, the distinction between 'culture' and 'capacity', let alone between 'morality' and 'power' is not so easy to make. Perhaps the British could simply 'afford' to be more benign in view of their capacity to wield hard power?

Our working hypothesis is that the global scale of the British empire in the era 18501940, which was grounded in the growing strength of its industrial economy and related military and naval supremacy, created four specific advantages that Portuguese colonial 
administrations lacked. First, the economies of scale and scope inherent to the creation of a violence monopoly. The Portuguese had fewer options to pool military resources in situations of crisis and required larger permanent forces in the colonies to secure order. Moreover, Angola and Mozambique were surrounded by 'foreign' powers, whereas British colonies and protectorates often bordered one another. Economies of scope were reaped through the transfer of military skills, experience and technical knowledge via professional army trainers. Second, a larger empire created more possibilities for cross-subsidies, even though most of these were implicit and occasional. The prominent example is the role of the vast Indian army, which has been deployed in many parts of Asia, Africa and Europe on the account of Indian tax-payers. Third, Britain could rely on a strategy of credible deterrence to settle conflicts or disputes before they escalated into a violent confrontation. Put differently, gunboat diplomacy was an option open to Britain, but much less so to Portugal. Fourth, if these advantages played out as we hypothesize, British colonial administrations were more effective in expanding local tax bases and thus managed to solve the catch-22 more easily, that is, financing local armies with local taxes without relying on large structural subsidies from the metropole.

Lacking the advantages of scale economies, imperial redistribution of military resources and means of credible deterrence, the Portuguese colonial state had to invest (much) more of its resources into the security imperative. These expenses were not only needed to defend colonial borders, but also to gain some leverage at the European negotiation table. This implies that larger parts of the colonial budget in Portuguese Africa had to be devoted to security expenses, that fewer means were available for welfare development and that financial back-up from the metropole was required for a longer period of time. More intensive militarization also implied a policy focus on army recruitment and related fiscal incentive structures. To make this work, the colonial army would have to be ingrained more deeply into the fabric of indigenous society.

Our historical investigation draws on a combination of primary and secondary sources and zooms in on three comparative dimensions of militarization. First, we explore the relative costs of the military apparatus. Using annual series of fiscal accounts retrieved from colonial archives in London and Lisbon we compare the extent to which military expenses pressed on colonial state budgets and on the contributions of metropolitan tax-payers. We also use these sources to analyse expenditure trends over time. Second, we compare the size of the colonial armies in absolute and relative (per capita) terms. We explore the organization of the military and the possibilities of cooperation and exchange of troops between Angola and Mozambique. 
We document how army mobility in Portuguese Africa differed from British army operations in West and East Africa, and the deployment of non-African soldiers at times of crises (e.g. WWI). Third, we explore the link between the army and forced labour recruitment. With rising international - especially British - opposition against the use of forced labour in the 1920s (an important albeit implicit source of non-monetary tax revenue), the army started to serve as a shadow work force in Portuguese Africa. We explore to which extent this practice was rooted in recruitment practices of the early colonial state.

Based on our analysis of the historical data we conclude that the fiscal-military development of the colonial states in Portuguese Africa differed markedly from those in British West and East Africa. We contend that most of the evidence, including a tentative examination of the Belgian Congo, is consistent with the idea that the jackals of imperialism needed more teeth and that the costs of these additional security investments were diverted to both indigenous and metropolitan tax-payers. High degrees of local recruitment were reflected in a deeper embedding of the army in the Portuguese colonies and this legacy helps to explain the exceptional intensity and prolongation of the civil wars that plagued both countries in the 1970s to 1990 s after the already intensive wars of independence in the 1960s and early 1970s.

The remainder of this chapter consists of six sections. Section 4.2 and 4.3 offer the historical context required to understand the key challenges of colonial governance in Angola and Mozambique, section 4.4 presents the main empirical results, 4.5 places the results in the British African mirror, 4.6 extends the comparative scope and 4.7 concludes with a discussion of the long-term consequences of the varying trajectories of fiscal and military development in colonial Africa.

\subsection{The jackal and the lion}

Portugal was the first European nation to sail down the coastline of West Africa in the $15^{\text {th }}$ century, to erect coastal settlements and to develop trade relations with African polities. The baptization of the Kongo king Nkuwu Nzinga (João I) by Portuguese missionaries in 1491 symbolized the successes of Portuguese imperialism in the late $15^{\text {th }}$ century. However, around 1850 those glory-days were long gone. Portugal had lost its main Atlantic possession, Brazil, in the early 1820 s and was pressed by Britain to end the trans-Atlantic slave trade, which had served as a major source of revenue for centuries. When the scramble for Africa set off in the 
1880s, and especially after the Berlin conference agreement (1884-5) that territorial claims in Africa were conditional upon effective military control (Herbst 2000, p. 71-72), Portugal had to rush to occupy the hinterlands of what became Angola and Mozambique, if it wasn't to leave these areas to European contenders such as Germany or Britain.

Britain's global hegemony reached its zenith during the second half of the $19^{\text {th }}$ century. Britain's imperial expansion was underpinned by an industrial revolution which generated abundant investment capital, sophisticated military and logistic technologies and an extensive global network of entrepreneurs, governors, bureaucrats, missionaries and military officers. The British lead over Portugal in GDP per capita doubled from roughly 2:1 in 1820 to 4:1 in 1914, while the difference in total GDP rose from about 12:1 to 30:1 (Maddison 2010). The British navy, floated mainly by British tax receipts, served as the logistic backbone of imperial power as it facilitated a rapid and safe exchange of troops within and across continents (Davis and Huttenback 1986, Cain and Hopkins 2001).

In 1885, right after the Berlin conference, the Foreign Ministry in Lisbon circulated the so-called Mapa cor-de-rosa with Portugal's claims in Central Africa (see map 4.1). According to the Portuguese government these claims were based on prior discovery (Newitt 1995, p. 341). Yet, the eventual partition of territory became a matter of international diplomacy where the jackal had to give in to the lion. After a series of negotiations and movement of troops in the African interior, Lord Salisbury sent an ultimatum to the Portuguese government in 1890, demanding the withdrawal of the Portuguese troops from the areas where Portuguese and British interests overlapped (Pinto Coelho 1990, p.173). This ultimatum set the stage for the Anglo-Portuguese treaty of 1891, in which the borders of Mozambique and Angola were defined. Portugal thus held on to some of its possessions in sub-Saharan Africa - as well as some smaller colonial enclaves in Asia (e.g. Timor, Macau, Goa) - but it required both British consent and military assistance to sustain its claims. ${ }^{78}$ The lion left the jackal with two reasonably sized, but separated pieces of territory that were bound to be separately administered and secured.

Portugal's imperial trade relations were also affected by British influences. Portugal's industrial sector was too weak to compete with British export manufactures in foreign markets, and failed to develop a sizeable demand for tropical cash crops and raw materials from its African dependencies, with the debatable exception of cotton feeding Portuguese textile

\footnotetext{
${ }^{78}$ For instance, when the Germans invaded Angola from the south during WWI, British support was needed to defend the borders of this colony (Arrifes, 2004).
} 
factories. Colonial railways were mainly constructed by British companies and a big part of the plantation complex was also British owned. Instead of catering to colonial markets, or upscaling the production of raw materials for Portuguese factories, colonial policies were focussed on protecting imperial trade flows in order to skim off the margins involved in re-exports of British manufactures flowing into Portuguese Africa, as well as tropical commodities coming the other way around to end up in major European consumer markets (Clarence-Smith 1985, p. 172-6, Lains 1998, p. 239).

\section{Map 4.1: The pink map (Mapa cor-de-rosa), 1884-85}

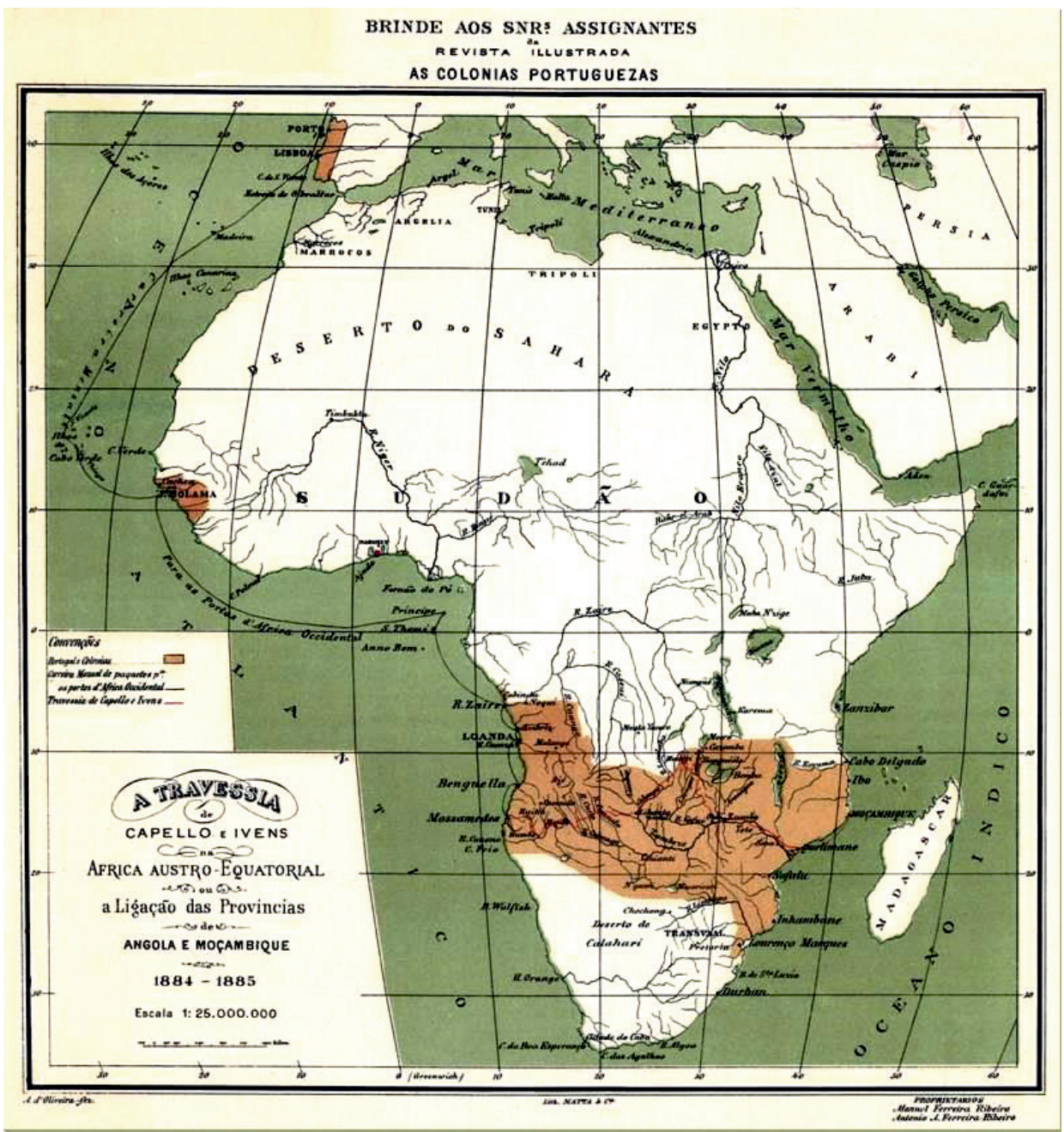

Source: Carta da Africa Meridional Portuguesa. Lisboa: Commissão de Cartographia, 1886 


\subsection{Conquest and military control}

Establishing military control over the extended hinterlands of Angola and Mozambique was a matter of decades, not years. Before 1885 Portuguese invasions in the hinterland of Angola were mainly to settle conflicts in the slave trade and establish commercial outposts. The first real wars of territorial conquest started after 1885 in the south against the Ovambo and then spread to the Bie Plateau in 1902 in the centre of the country, where the Ovimbundu revolted against oppressive labour conditions and Portugal's interruption of the rubber trade. After a particularly difficult campaign the Portuguese conquered the Dembos in the north, but it was only in 1920 that the colonial government could claim to have 'pacified' the entire country (Bender 1978, p.138).

In Mozambique, the prazo-holders, who had dominated the Zambezi area - the central zone of Mozambique - from the $16^{\text {th }}$ to $19^{\text {th }}$ centuries, played a major role in the organized resistance against Portuguese occupation. The prazeiros had accumulated their wealth in the slave and ivory trades, but had also obtained land titles (prazos da coroa). The prazeiros used private slave-soldiers (chikunda) to secure their property and collect taxes. Although military slavery was not uncommon in pre-colonial Africa, these prazo-armies were exceptional in that African slaves were serving the interests of private European settler families (Isaacman and Peterson 2003, pp.257-260). ${ }^{79}$ Originally the prazeiros were to act as delegates of the Portuguese Crown, but after centuries of intermarriage they developed a degree of autonomy and mixed race identity that turned them into "the chiefs of the newly emerging African peoples" (Newitt 1969, p.85).

Campaigns in the Zambezi valley started as early as 1869 , but only with support of British forces the Portuguese managed to crack the prazo-armies in the 1890s. The central regions of Manica and Sofala were handed over to large concession companies such as the Companhia de Mocambique and Companhia de Zambezia. Both companies were dominated by British capital and were primarily engaged in plantation agriculture. The former also obtained a charter that allowed the company to tax and police local inhabitants and to recruit indigenous labour. This form of colonial governance through semi-private companies resulted in a patchwork of administrative and fiscal systems in Mozambique, which was one of the main

\footnotetext{
${ }^{79}$ The French also used African slaves to build up a corps of colonial infantry in French West Africa (Tirailleurs Sénégalais), see Klein (1998).
} 
contrasts with Angola, where a more homogenous fiscal and military administration was topdown imposed (Azambuja Martins 1939, pp. 570-1; Alexopoulou and Juif 2017).

The colonial armies initially consisted of a first-line force staffed by European soldiers, varying in numbers up to 2,000 men, and a second-line force, much larger in size, staffed by African auxiliary and irregular forces known as guerra preta (Wheeler 1969, p. 426). Portuguese soldiers tended to be better trained and better equipped. For this reason, Portuguese troops led the military campaigns in the south of Angola against the Ovambo people between 1901 and 1907. Yet, indigenous soldiers were cheaper to recruit and their susceptibility to (fatal) tropical disease was much lower (de Oliveira Marques 2001, p. 269). African recruits were mustered by chiefs (sobas) who were loyal to the colonial state. The general governors of the colonies set quota for recruits per province (Arrifes 2004, p. 240). Chiefs were reported to receive 4.500 to 8.000 Reis for each army recruit (Ferreira 1905, p. 1041), which was the equivalent of 4.5 to 8 Escudos or 0.9 to $1.7 £^{80}$. In addition to the recruitment of soldiers and corvée labour, the chiefs also collected hut taxes in exchange for certain privileges such as tax exemptions.

While the Portuguese navy remained crucial for the defence of the coastal zones in both parts of Portuguese Africa (Arrifes 2004, p. 64 and 97), the number of ground troops were rapidly expanded. By the end of the $19^{\text {th }}$ century, only 374 out of ca. 8.000 soldiers in the colonial army were registered as European (Carrilho 1985, p. 110), although the arrival of expeditionary forces from Portugal would change such ratios considerably (Wheeler 1969, p. 428). The wish to raise the number of African recruits motivated a major re-organization of the colonial army, enforced by a decree in 1901 and subsequent regulations in 1904. It entailed a first attempt to systematically organize the recruitment of indigenous soldiers (Limão Gata 1952-53, pp.41-45), and to separate the financing of the metropolitan and colonial army regiments. The former now officially resorted under the Maritime (Marinha) and Overseas (Ultramar) Ministries and were paid by the treasury in Lisbon. The latter resorted under the colonial government and were, at least in theory, paid from the colonial state budget (Arrifes 2004, p. 61). Colonial government investments in transport infrastructure and communication and intelligence systems were to improve army mobility and create permanent army posts in the interior (Arrifes 2004, p. 64; da Silveira 1938).

\footnotetext{
${ }^{80}$ Conversion rates from Valério (2001, p. 745).
} 
Soldiers were classified into four categories: army volunteers, contract soldiers, forced and recruited soldiers: Voluntarios consisted of skilled wage labour (i.e. drivers) that freely joined the army and received premiums (for 2 years); Contractados were wage-earners, often pushed by indigenous chiefs to sign fixed-term contracts (minimum 3 years) with the colonial army, and received premiums; Compelidos consisted of forced unpaid labour, including punitive labour and war hostages (usually for 4 years); Recrutados were forcibly recruited soldiers by native chiefs or colonial administrators to serve the army (for 3 years), in case of acute shortages during wartime (Provincia de Mocambique 1904, pp. 9-10 and República Portuguesa 1914, p. 6). No doubt the contracts of all indigenous recruits were often violated (Keese 2012).

In 1910 these reforms came under attack because the operational capacity of the colonial army remained disappointing. Military officials complained about the lack of proper training and the limited availability of army trainers, about poor military equipment and the fragile discipline of African recruits (Arrifes 2004, p. 250). However, with the Republican take-over in Portugal in 1911, Lisbon opted to grant more autonomy to the colonial governments rather than less (Arrifes 2004, p. 65). The new governor of Angola, Norton de Matos, a staunch Republican, proposed to abandon forced labour and forced army recruitment altogether (de Matos 1944), but these ideas deepened the distrust between metropolitan and colonial army officials. Portuguese officers serving in the colonies warned that the burden of imperial defence would shift more onto Portuguese soldiers and tax-payers when forced recruitment was no longer allowed and were dissatisfied with the abolition of some of their political and administrative privileges (Arrifes 2004, pp. 63, 67).

During WWI, expeditionary forces were sent from Lisbon in response to German threats at the Southern frontier of Angola. The colonial government urged chiefs to raise the numbers of local recruits, which resulted in tens of thousands of newly enlisted, poorly trained men to the colonial forces (Azambuja Martins 1939, p. 591). Volunteers coming from Portugal had to serve for 2 years, while Portuguese settlers between 20 and 30 years old had to serve for 5 years (Arrifes 2004, p. 73). While Portuguese soldiers were used at a considerable scale in times of crisis, the exchange of indigenous regiments across Portuguese colonies remained modest. Indian soldiers from Goa were part of the early 1869 campaigns in the Zambezi valley. Recruits from Angola also assisted in these campaigns (Enes 1946, p.115, Newitt 1995, p. 315). After the consolidation of the Zambezi valley in the 1890s, companhias consisting of 118 to 210 men were sent from Mozambique and Angola to the Asian dependencies of Goa, Macau and Timor 
(Salvagem 1931, p. 591, Coelho 2002, p.133). A list of companhias dispatched from Mozambique between 1904 and 1932 shows that usually only one or two companhias served abroad at the same time (Azambuja Martins 1939, p. 34). Yet, in August 1914 two were sent off to Angola, and two went to Timor to replace the troops that had been sent there in 1912 to supress the Manufahi rebellion - a revolt against attempts by the colonial authorities to enforce head taxes and corvée labour. However, without British support the Portuguese would not have been able to stop the German invasion in Southern Angola, as this required much more than a few hundred poorly equipped Landims from Mozambique. ${ }^{81}$ Moreover, compared to the approximately 25,000 soldiers who were recruited in Mozambique to stall the German invasion of Northern Mozambique from Tanganyika, the intra-empire movement of troops was just a trickle.

After the military coup of May 1926, António de Oliveira Salazar became responsible for averting a state bankruptcy as the new Minister of Finance of the military regime. He immediately started to cut back Portugal's military expenses and reduced all metropolitan transfers to virtually zero. In 1932 Salazar became the First Minister and in 1933 he proclaimed the Estado Novo (also coined the $2^{\text {nd }}$ Republic). His government re-organized imperial defences by introducing a new tax, imposto de defesa, to finance the colonial army (Moreno 1937, p.13). The moral mission of the colonial army to "nationalize" indigenous soldiers via military training was re-enhanced (Azambuja Martins 1938, pp. 64-65) and the conditions of military conscription of Portuguese settlers were tightened (Moreno 1937, p.4).

There is much to say about military developments in Portuguese Africa during WWII and the wars of independence from 1961 to 1974, when Portugal became one of the most militarized nations in the world in terms of men under arms (Coelho 2002, p.137), but this era falls outside the scope of this chapter, as do other Portuguese colonies in Africa such as Guinea, Cape Verde and Sao Tomé. There are two points we need to make before moving on to the empirical analysis. First, the Salazar regime continued to focus on the 'Africanization' of its imperial forces and it were, therefore, African troops that were responsible for the suppression of local insurgencies and upcoming nationalist movements. The prolonged and devastating civil wars in Angola and Mozambique after independence cannot be understood without this colonial legacy of intensive inter-ethnic violence in the context of two relatively fragile colonial states. Second, whereas the militarization up to 1914 was partly subsidized by financial grants from

\footnotetext{
81 "Landim" is Portuguese for "landrace", which was often used in reference to local cattle and indigenous inhabitants of Southern Mozambique.
} 
Lisbon, these grants were turned into loans during the 1920s and debt servicing became a growing expenditure post for both colonial states ${ }^{82}$.

\subsection{Military expenditure in Angola and Mozambique}

With this historical context in mind we proceed to analyse the expenses that were incurred in the development and operation of the colonial armies in Angola and Mozambique. We assembled data of central government spending on military, marine and police forces in the annual fiscal accounts (orçamentos gerais) which were published in yearbooks, newspapers and ministerial reports. For the period 1850-1885 we could only find data for benchmark years, for the post-1885 era we were able to construct annual time-series up to 1940 . The concession companies that were active up to the 1930s had their own police forces, which are not covered in the state accounts (Moreno 1937, p. 10).

Figure 4.1 shows the share of total central government expenditure allocated to the colonial army in both countries - including some minor marine expenses. Figure 4.2 shows real security expenditures divided by estimates of total population derived from Frankema and Jerven (2014). Combining these two graphs allows us to make four observations.

First, despite some important disparities, the overall trends in security spending in Angola and Mozambique were similar: a gradual decline up to the 1880 s, followed by increasing expenses during the 1880 s to 1900 s, when most of the campaigns to occupy and secure the hinterland areas were staged. ${ }^{83}$ After these campaigns were concluded, the budget shares again declined rapidly. In the mid-1920s security expenditures had come to down to about 10 to 20 percent of the budget, and they retained this order of magnitude up to 1940 . Second, during the 1850 s to 1870 s more than half of both colonial budgets were devoted to military expenses. This is not surprising, because budgets in those years were tiny and only expanded due to increasing trade revenues later in the $19^{\text {th }}$ century. The drop in the shares from 1850 to 1885 was the result of growing state budgets, not of diminished military investments. In the 1920s and 1930s the decline was caused by real reductions in military spending.

\footnotetext{
${ }^{82}$ See Colonia de Angola (1921-1929). Orçamento Geral. Luanda: Imprensa Nacional.

${ }^{83}$ Pelissier (1987) has accounted for 121 military campaigns in Mozambique (1854-1918) and their causes: political and administrative pressure, tax collection, repression, banditry and loot.
} 
Third, the most important disparity between the two colonies is the earlier decline in the military spending share in Mozambique. The colonial state of Angola spent almost half of its budget on the army in the years 1914-18, while in Mozambique the shares continued to fall to around one fifth. The trend reversal in Mozambique around 1904 is consistent with the fact that most areas in Mozambique were by then brought under control, and that part of the security effort was being outsourced to private concession companies operating in the central and northern zones of the country. In Angola, the colonial state remained engaged in a series of wars up to 1920 . These wars were fought against relatively well organized coalitions of African polities. The most prominent example is the war against the Dembo people, who lived northeast of Luanda and were the last Mbundu tribe to be defeated by the Portuguese. In the official records the Dembos-Portuguese war lasted 3 years, from 1907 to 1910 and involved considerable numbers of casualties at both sides. In reality, however, the Dembos were only subdued in 1920 (Magno 1934). Part of the rise in military spending during WWI was related to these 'pacification' wars, while British colonial forces assisted in the defence of Angola's external borders against German invasions from the South.

\section{Figure 4.1: Share of security spending in total expenditure, Angola and Mozambique,}

\section{0-1940}

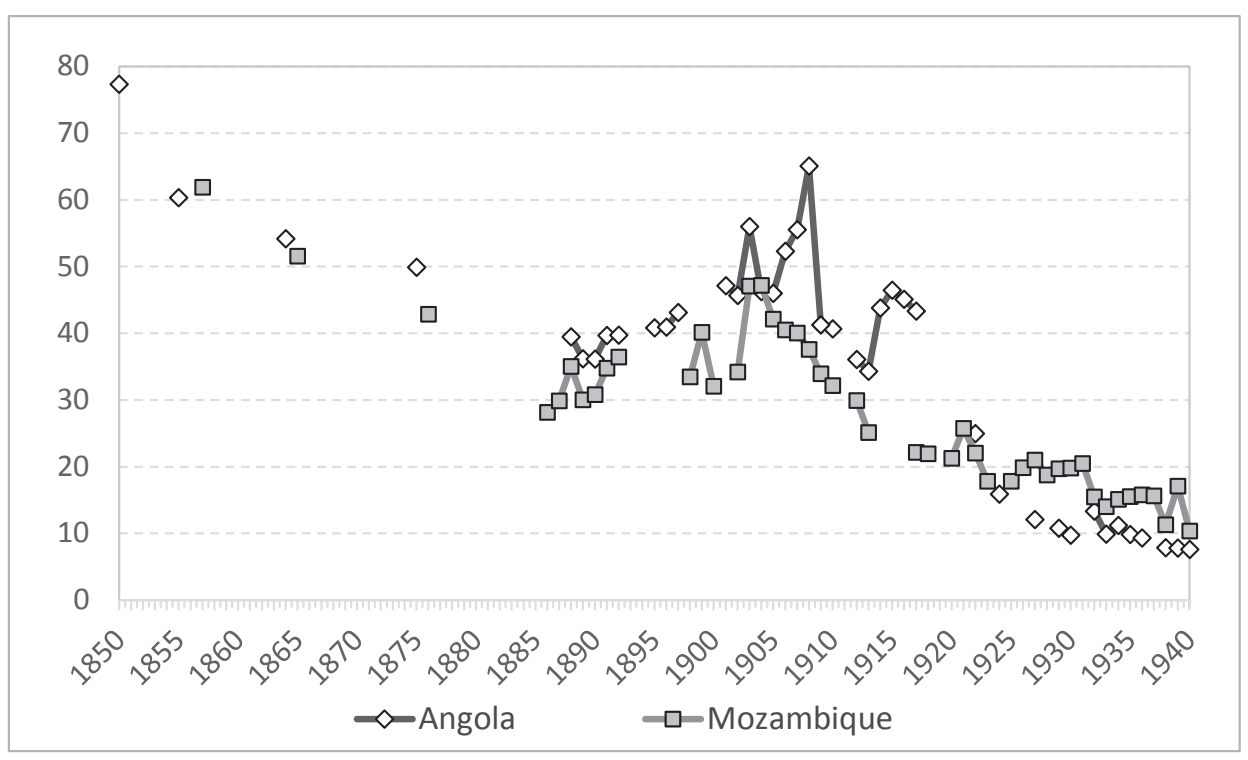

Sources: Boletim Official, Orçamentos Gerais (General Budgets) and Anuários Estatísticos (Statistical Yearbooks) of Mozambique and Angola, various issues between 1850 and 1940. 
Figure 4.2: Real per capita expenditure on security forces, Angola and Mozambique, 1850-1940 (in 1914 Escudos).

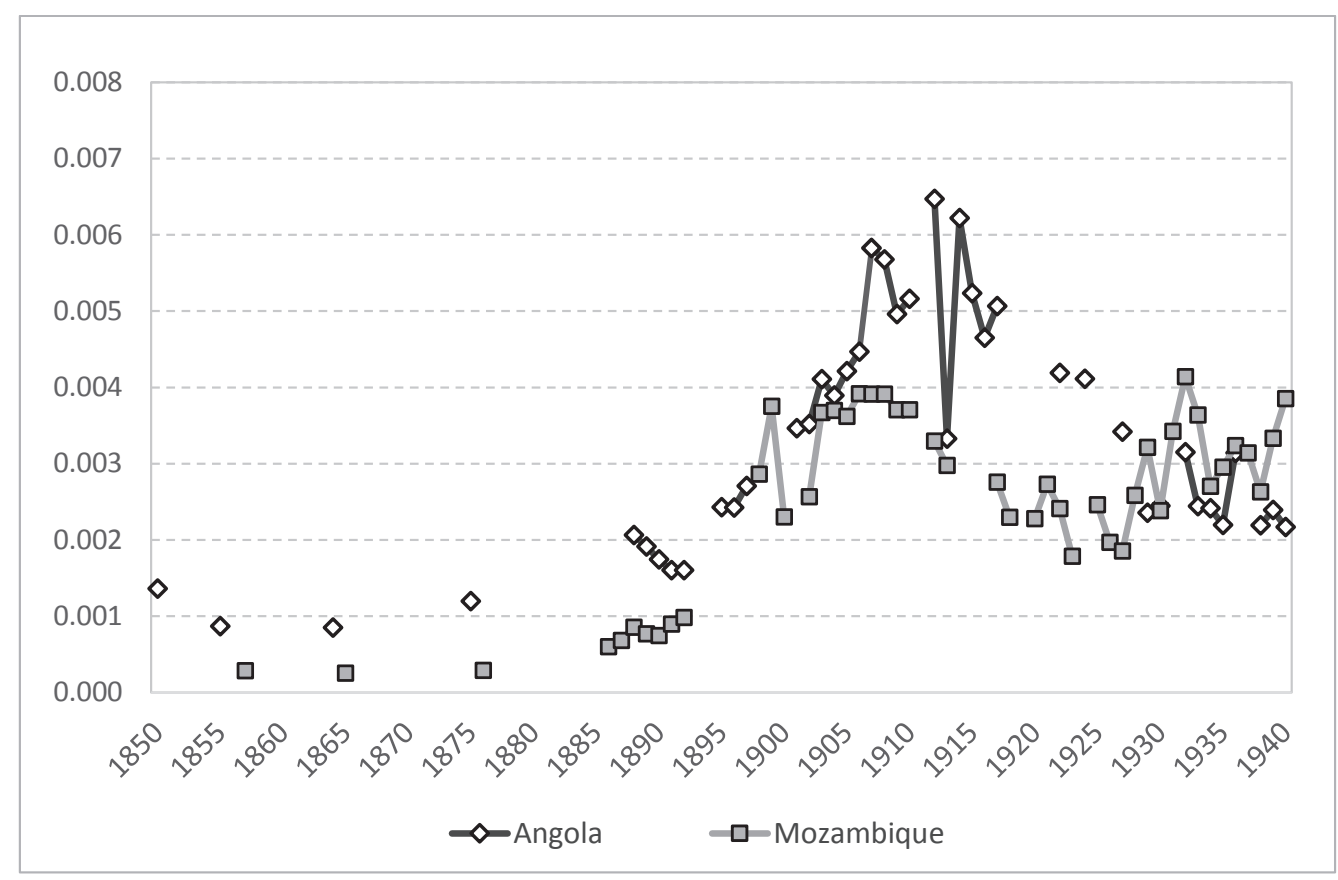

Sources: For expenditure data see figure 4.2. Price index from Valerio (2001), Table 8.1.

Note: For the years 1918-1927 we made a downward adjustment of Valerio's price index, because his values were too high to render reliable results for the purchasing power of the central budget in both colonies; population estimates from Frankema and Jerven (2014).

Fourth, after the establishment of effective military control, the per capita budget reserved for security forces became smaller in Angola than in Mozambique. This is not only corroborated by the deflated expenditure series presented in figure 4.2 , but also by the underlying nominal expenditure series. There are three interrelated explanations for this reversal. Firstly, the colonial state in Mozambique took over security tasks in the 1930s that were previously carried out by concession companies. This demanded extra resources, and even more so because the army had to control three rather disconnected areas, which complicated the generating of economies of scale in maintaining law and order (Alexopoulou and Juif 2017). Secondly, 
Angola was not only a politically more homogenous state than Mozambique, the army also benefitted from a more extensive railway network. After WWI it could maintain a larger army of African soldiers at lower costs. Thirdly, Angola in this period received most of the subsidies and loans granted by Lisbon to open up the hinterlands.

So far, we have concentrated on colonial state budgets, but financial transfers from Lisbon did play a considerable role as well. According to Telo (1994a, p. 156) there was no other European metropole that spent so much on the consolidation of its empire in relative terms as Portugal. These transfers were almost exclusively destined for military spending and infrastructural investments, categories which are hard to disconnect because of the strategic importance of roads, railways and ports for army operations.

Figure 4.3 shows the total contributions from Lisbon to the overseas dependencies, of which Angola and Mozambique received the bulk. ${ }^{84}$ The data we collected, albeit patchy before 1913, reveal several important trends. First, the declining share of metropolitan subsidies after 1885 corresponds with the rapid increases in colonial state revenues (see figure 4.3). Hence, the extra military costs incurred during WWI were mainly paid from local tax revenues and forced deployment of unremunerated recruits. Second, the peak in the mid-1920s reveals how Republican investments in colonial - especially Angolan - infrastructure brings Portuguese state finances in dire straits. Salazar's austerity measures put an almost immediate end to all overseas transfers, and these constraints were only eased after WWII. More important, however, is the granting of fiscal autonomy to the colonies in 1914, which does not show up in this graph. It meant that investment capital in colonial development projects - railways in particular - were increasingly provided in the form of loans rather than grants-in-aid. Shares of debt servicing expenses in the colonial budget thus rose correspondingly. Finally, the rising costs of the independence wars are visible from 1960 onwards.

A comparison with French financial contributions to the army in French West Africa gives us a good sense of the burden that Portuguese tax-payers carried in order to secure the empire. According to the data shown in figure 4.3, Portugal spent on average about $2.5 \%$ of its total expenditure budget on transfers to the colonies between 1875 and 1914 and over $3.0 \%$ of its overall tax revenues (part of the transfers were covered by Portuguese state debt). According to Huillery $(2014$, p. 1) the French spent on average $0.24 \%$ of their annual domestic expenditure

\footnotetext{
${ }^{84}$ Though in relative terms - i.e. per capita - the smaller colonies such as Cape Verde, Sao Tomé, Macau and Timor may have benefitted more (Ferreira and Pedra 1988, p. 92).
} 
budget on the army in French West Africa between 1844 and 1957, and another $0.05 \%$ on development projects. A huge difference indeed.

But the most telling comparative statistic is that French transfers added less than $2 \%$ to locally raised revenues, whereas the transfers from Portugal to its colonies up to 1914 approached 20\% per year on average (Boletim Official de Moçambique 1889). British policies were even more stringent. Grants-in-aid to African colonies were never provided on a structural basis, and even though their overall value may have been high in the first years after the establishment of a colonial state administration, these grants were reduced to zero as quickly as possible. For instance, the East Africa Protectorate (the Colony of Kenya from 1920 onwards) which became formally administered by the Foreign Office in 1895 received over $50 \%$ in aid in the first decade, but around 1912-13 these grants were lowered to 2.5\% and a few years later completely abolished. This was possible because local revenues rose in less than ten years from 155 thousand pounds in 1904-5 to over 1,1 million pounds in 1913-14. In West African colonies such start-up-grants were hardly needed, because custom revenues sufficed as a basis to extend the fiscal system (Gardner 2012; Frankema and van Waijenburg 2014).

\section{Figure 4.3: Metropolitan transfers to the colonies in Portuguese government expenditure,} 1875-1974 (\%).

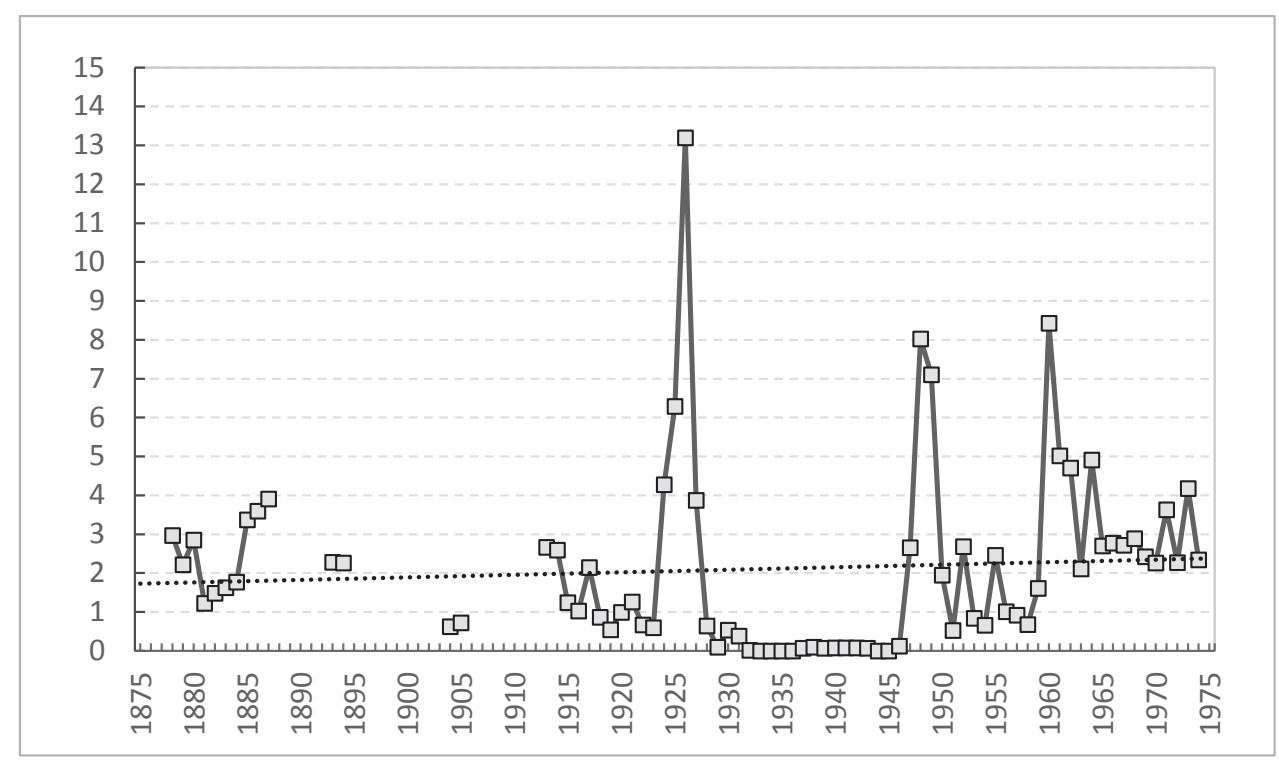

Source: Data pre-1913 from various issues of Boletim Official do Governo Geral da Provincia de Moçambique; Data for 1913-1974 from Ferreira and Pedra (1988, pp. 98-101). 
However, this comparison of fiscal transfers overlooks a key aspect of imperial security systems: the lion's share of colonial transfers remains implicit. French and British tax-payers contributed much larger sums in both relative as well as absolute terms to the development and maintenance of metropolitan military capacity, including naval power. This military capacity is crucial for the potential upscaling of local forces in colonial states, and indeed, the only way to underpin strategies of credible deterrence. For this reason, the recorded imperial transfers are not a very good indicator for the costs of consolidating empire.

This comparison illustrates how the catch-22 of co-creating a violence monopoly and an effective central revenue system occurred under very different conditions in Portuguese Africa, which had serious implications for indigenous tax-payers. Since a much larger share of the military resources had to be sourced locally the strains on the fiscal-military nexus were larger. Colonial governments developed a heavy reliance on forced labour, including forced army services, which affected thousands and thousands of young men and their families, who were forced to support the colonial state building project at minimal rates of compensation or worse, by loss of life.

\subsection{The British African mirror}

What did the militarization of Portuguese Africa look like in the British African mirror? Contrary to Portuguese Africa, large parts of British Africa were occupied with the support of imperial troops from outside Africa. Troops from the British West Indies played a key role in the occupation of West Africa until most of their tasks were taken over by the West African Frontier Force (WAFF), established in 1900 (Killingray 1983). In East Africa the British Indian army was leading in the occupation effort. And even though the deployment of Indian troops had been expensive and became increasingly unpopular in India, they also played a crucial role in the invasion of German East Africa (Moyse-Bartlett 2012, pp. 123-4). Only in 1916 the British decided to shift the burden of the fighting to newly forged battalions of the King's African Rifles (KAR) (Parsons 1999, p. 18), but assistance from Indian and South African troops remained crucial, also to protect poorly equipped Portuguese garrisons (Newitt 1995, pp. 419-420).

Spreading army costs by promoting the mobility of troops formed an integral part of British imperial governance in Africa. The WAFF was to secure four geographically separated 
colonies in West Africa (Gambia, Sierra Leone, Gold Coast, Nigeria). In 1896, Chamberlain ordered the colonial office to consider "how far we can gradually organize a military police, real fighting men all through the West coast colonies - interchangeable ... being used in emergencies for any part of the coast." (cited in Killingray 1983, p. 442). Its first commander, Frederick Lugard, pleaded for a full integration and central coordination of the four divisions, including identical uniforms, similar arms and equal contractual conditions (time of service, pay). Lugard reasoned that a unified force would guarantee concerted action against a foreign power (i.e. France). Hodgson, the Gold Coast governor objected the amalgamation of divisions, as it would withdraw powers from colonial governments aware of local conditions and needs (Ukpabi, 1987, p. 65-7).

In British East Africa the KAR was erected in 1902 and incorporated the original forces of the protectorates: Two Central Africa battalions, the East Africa battalion, two Uganda battalions and the Somaliland battalion (Moyse-Bartlett 2012, Vol.1, p. 129). Increasing investments in the training and organization of KAR soldiers under a unified command structure occurred during the final two years of WWI (Parsons 1999, p. 18-20). In order to train African recruits, the British dispatched officers who had made a career elsewhere in Northern Africa (e.g. Egypt, Sudan), South Africa, Southern Asia or the Caribbean. The selection of martial races also followed earlier imperial experiences, and especially those of army formation under the British Raj after 1857 (Parsons 1999, p. 54). For instance, the regiments of the WAFF stationed in the Gold Coast were initially staffed by Yoruba and soldiers from the Hausa-Fulani tribes were also acknowledged for exceptional martial skills (Ukpabi, 1987, p. 88). In East Africa semi-pastoral peoples such as the Nandi (Kalenjin) or Somali were wanted, in part also because of their vehement resistance against colonial rule (Parsons 1999, p. 54). The preference for specific ethnic groups was a widely adopted form of identity politics to improve coherence and commitment, building on sentiments of superiority of recruits versus local ethnic groups.

Since the WAFF and the KAR retained a relatively small operational force during peace times, forced recruitment was the exception, voluntary service the rule. The rates of pay tended to be above market rates for civilian jobs, and the army offered other material advantages in the form of uniforms, shoes, housing, food, training. Instead of paying chiefs to recruit soldiers, the armies in British Africa were in a position to be selective and select enlistees on medical grounds, fighting skills and height (Parssons 1999, Moradi 2009). Because of this selectivity and the stricter focus on military tasks, rather than large scale recruitment of men for all sorts of labour, these troops received much better training than the average recruit in the Portuguese 
colonial army. As the WAFF and the KAR gained strength, the movement of troops within Africa became more important, as would show for instance in the liberation campaign of Ethiopia in 1940-41 (Parsons 1999, p. 26).

Table 4.1 shows that, in relative terms, the public revenue invested in military and marine forces in Portuguese Africa was much larger than in British Africa. Whereas military expenses in Portuguese Africa consumed more than half of the state budget in the mid- $19^{\text {th }}$ century, and still a full one-third in 1913, in British Africa expenses ranged between 2.7 and 10.3 percent. The gradual decline of security expenditure shares in Portuguese Africa inevitably led to some convergence, but even in the 1920s and 1930s, the differences remained substantial. Relatively high shares of spending recorded in the Gold Coast in 1888 and Sierra Leone in 1898 were either caused by warfare - i.e. the hut tax war of 1896-1898 in Sierra Leone - or the delayed payment of a war bill in an area with prolonged conflict - i.e. there were five AngloAshanti wars between 1824-1901. This huge gap can certainly not be explained by higher British subsidies. Even though London occasionally took the bill of military operations in the early stages of colonial state formation, this type of 'start-up subsidy' never lasted long. Parts of the costs incurred in the conquest were also converted into colonial state debt, and re-paid by indigenous tax-payers in the form of amortization and interest.

Yet, higher budget shares allocated to the military in Portuguese Africa didn't necessarily mean that absolute expenses on the army were higher as well. To compare absolute expenses per head of the population, we took the reconstructed population series from Frankema and Jerven (2014) and converted Escudos into current British Pounds using official exchange rates. ${ }^{85}$ Up to 1918 these exchange rates were relatively stable and are unlikely to affect the comparison much. With rampant inflation during the years 1918-1925 the use of official exchange rates may distort the comparison, so we have to be careful not to place too much weight on the 1920 and 1925 benchmark. The overall picture is clear nonetheless. In Portuguese Africa, the absolute per capita amount of money spent on the army was at least double the amount recorded in British West and East African colonies, and up to 1920 it was even much more than that.

\footnotetext{
${ }^{85}$ Although these population figures are based on extrapolated census estimates from the 1950 s, they are to be preferred over contemporary census reports. Colonial censuses systematically underestimated African populations amongst others due to a lack of administrative capacity and deliberate underreporting by indigenous rulers. Undercounting was likely more severe in areas that remained outside colonial control.
} 


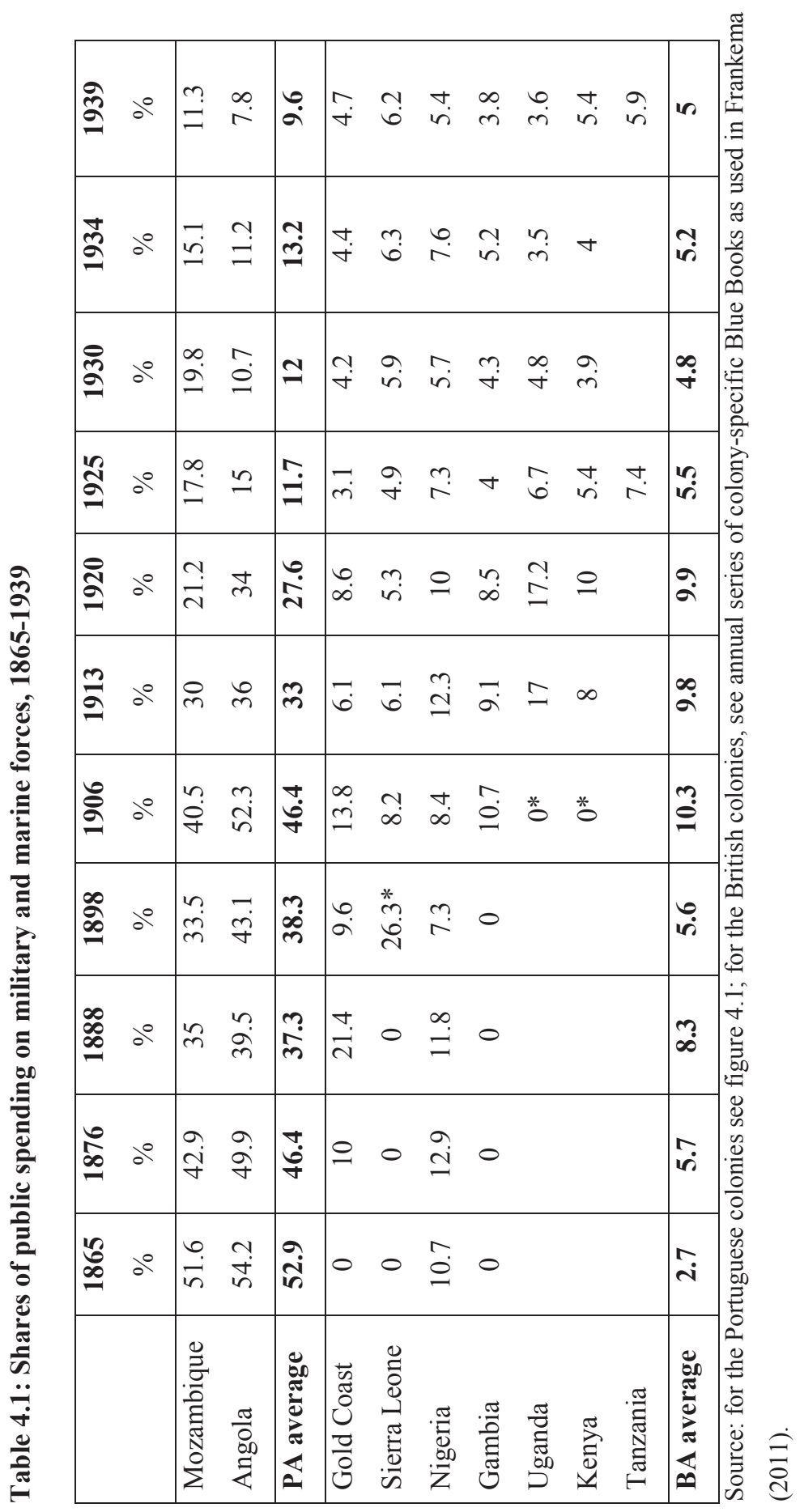


Table 4.2: Public spending on military forces per capita (in British pounds), 1898-1939

\begin{tabular}{lcccccccc} 
& $\mathbf{1 8 9 8}$ & $\mathbf{1 9 0 6}$ & $\mathbf{1 9 1 3}$ & $\mathbf{1 9 2 0}$ & $\mathbf{1 9 2 5}$ & $\mathbf{1 9 3 0}$ & $\mathbf{1 9 3 5}$ & $\mathbf{1 9 3 9}$ \\
\hline Mozambique & 0.04 & 0.08 & 0.06 & 0.02 & 0.02 & 0.07 & 0.04 & 0.06 \\
Angola & 0.04 & 0.09 & 0.09 & 0.12 & 0.04 & 0.05 & 0.05 & 0.05 \\
PA average & $\mathbf{0 . 0 4}$ & $\mathbf{0 . 0 8}$ & $\mathbf{0 . 0 8}$ & $\mathbf{0 . 0 7}$ & $\mathbf{0 . 0 3}$ & $\mathbf{0 . 0 6}$ & $\mathbf{0 . 0 5}$ & $\mathbf{0 . 0 6}$ \\
\hline Gold Coast & 0.01 & 0.03 & 0.02 & 0.03 & 0.03 & 0.03 & 0.02 & 0.03 \\
Sierra Leone & 0.03 & 0.02 & 0.02 & 0.03 & 0.03 & 0.03 & 0.02 & 0.02 \\
Nigeria & 0.00 & 0.00 & 0.01 & 0.02 & 0.02 & 0.01 & 0.01 & 0.01 \\
Gambia & 0.00 & 0.00 & 0.03 & 0.04 & 0.05 & 0.05 & 0.04 & 0.04 \\
Uganda & & 0.00 & 0.01 & 0.03 & 0.02 & 0.02 & 0.01 & 0.02 \\
Kenya & & 0.00 & 0.02 & & 0.03 & 0.03 & 0.03 & 0.04 \\
BA average & $\mathbf{0 . 0 1}$ & $\mathbf{0 . 0 1}$ & $\mathbf{0 . 0 2}$ & $\mathbf{0 . 0 3}$ & $\mathbf{0 . 0 3}$ & $\mathbf{0 . 0 3}$ & $\mathbf{0 . 0 2}$ & $\mathbf{0 . 0 3}$
\end{tabular}

Sources: For the expenditure data see figure 4.1 and Table 4.1; Population estimates from Frankema and Jerven (2014), database published at https://www.aehnetwork.org/data-research/; Escudo-GBP exchange rates from Valério (2001).

Table 4.3: Size of permanent colonial armed forces in colonial Africa, 1910 and 1930

\begin{tabular}{l|cc|cc} 
& $\mathbf{1 9 1 0}$ & $\mathbf{1 9 3 0}$ & $\mathbf{1 9 1 0}$ & $\begin{array}{c}\mathbf{1 9 3 0} \\
\text { soldiers per 1000 inhabitants }\end{array}$ \\
\hline \hline Mozambique & \multicolumn{2}{|c|}{ total size } & 1.1 & 0.8 \\
Angola & 4,600 & 3,500 & 4.1 & 2.2 \\
PA average & 11,000 & 6,740 & $\mathbf{2 . 6}$ & $\mathbf{1 . 5}$ \\
\hline Gold Coast & $\mathbf{7 , 8 0 0}$ & $\mathbf{5 , 1 2 0}$ & 0.5 & 0.3 \\
Sierra Leone & 1,400 & 1,273 & 0.8 & 0.3 \\
Nigeria & 970 & 385 & 0.2 & 0.1 \\
Gambia & 3,440 & 3,513 & 0.7 & 0.7 \\
Nyasaland & 126 & 152 & 0.1 & 0.4 \\
Uganda & 220 & 800 & 0.2 & 0.2 \\
Kenya & 800 & 720 & 0.3 & 0.3 \\
BA average & 1,200 & 1,440 & $\mathbf{0 . 4}$ & $\mathbf{0 . 3}$ \\
\hline Belgian Congo & $\mathbf{1 , 1 6 5}$ & $\mathbf{1 , 1 8 3}$ & 1.9 & 1.7 \\
French West Africa & 16,333 & 16,000 & 1.1 & 0.9 \\
\hline
\end{tabular}

Source: Army size data from Killingray (1982), Appendix 1, pp. 424-5; Population from Frankema and Jerven (2014). 
Table 4.3 shows that the higher expenses on the colonial army in Portuguese Africa were needed to keep up a much larger contingent of permanent forces than in the British colonies. In 1910 and 1930 the average per capita size of the Portuguese African army was about five times as large as the British African average. In 1930, the size of the army in Angola was double the size of the Nigerian army, while Angola barely had 3 million inhabitants, and Nigeria an estimated 24 million. Part of the difference between Angola and Mozambique may be explained by the different administrative systems. For Mozambique we lack data on the private mercenaries hired by, or forced to work for, the concession companies. If we were to add the number of men under arms servicing the companies, or alternatively, subtract the share of the indigenous population that paid their poll or hut taxes to the companies - the figures for Mozambique would be closer to the levels observed in Angola.

High military expenditures may be compensated by lower expenses on police forces. In British Africa police forces took, on average, about 5 to $8 \%$ from the state budget in the $1920 \mathrm{~s}$ and 1930s. In Portuguese Africa these shares were clearly lower, ranging from 2 to $4 \%$. If we were to combine these figures, the gap in per capita expenditure would be smaller, but far from closed. From the 1900s onwards the expenses on police forces (policia civil) started to be reported separately, but these expenses remained fairly low (da Silveira, 1938, p.534). In 191213 spending on police forces comprised 3.8\% of the total budget of Mozambique, in 1925-26 it was $2.5 \%$ and in 1934-35 it was again at 3.8\%. ${ }^{86}$ In Angola spending on public security (seguranca publica) ranged from 1.5 to $2.6 \%$ during the period $1929-1938 .{ }^{87}$ The fact that police forces were not a major spending category in both colonies is important, because it shows the reliance on the army in securing domestic order. Most of the police officers (cabos and cipais) were recruited from indigenous communities. Their salaries were lower than the salaries earned by either European or indigenous military officials (Contas da Gerência de Moçambique, Contas da Gerência de Angola). Moreover, in the zones where concessionowning companies ruled, policing as well as tax collection was executed by company employees, so that police expenses remained outside the accounts of the central administration.

Finally, it is worth investigating whether the higher military expenses in Portuguese Africa indeed led to lower budgets for welfare services, and in particular health and education. Table 4.4 presents estimates of welfare spending that we gathered from the annual fiscal accounts. This table confirms that welfare expenditure received lower priority in Portuguese

\footnotetext{
${ }^{86}$ In the case of Mozambique, for the period 1912-1928 data were retrieved from: Orçamentos da Receita e Tabelas da Despesa Ordinaria e Extraordinaria da Provincia de Moçambique, Imprensa Nacional, Lourenço Marques. For the period 1929-1940 data were retrieved from: Colonia de Moçambique, Relatorios da Direcção dos Servicos de Fazenda, Imprensa Nacional, Lourenço Marques.

${ }^{87}$ In the case of Angola, for the period 1929-1940 data derived from: Colonia de Angola, Orçamentos Gerais da Receita e Despesa, Imprensa Nacional, Luanda.
} 
Africa and that the gap in welfare spending increased especially in the $1920 \mathrm{~s}$. In the interpretation of these data it is also important to note that British colonial states in East Africa existed for a much shorter time than in British West Africa, but caught up in fiscal capacity during the 1920s (Frankema 2011) and surpassed Angola and Mozambique in welfare spending, despite the much longer military and fiscal presence of Portuguese in these areas.

Table 4.4: Expenditure on health and education as a share of total government expenditure in Portuguese and British Africa, 1920-1940

\begin{tabular}{l|lll|lll|llll|} 
& \multicolumn{4}{|c|}{ c. 1920 } & \multicolumn{5}{c|}{ c. 1930 } & \multicolumn{3}{c|}{ c. 1940 } \\
& Education & Health & Total & Education & Health & Total & Education & Health & Total \\
\hline \hline Mozambique & 1.3 & 8.9 & 10.2 & 1.1 & 6 & 7.1 & 2.5 & 6.5 & 8.9 \\
Angola & & & & 2.1 & 5.6 & 7.7 & 3.9 & 8.8 & 12.7 \\
\hline PA Average & & & & $\mathbf{1 . 6}$ & $\mathbf{5 . 8}$ & $\mathbf{7 . 4}$ & $\mathbf{3 . 2}$ & $\mathbf{7 . 7}$ & $\mathbf{1 0 . 8}$ \\
\hline Gold Coast & 4.2 & 9.2 & 13.4 & 6.8 & 11.2 & 18 & 7.4 & 13 & 20.4 \\
Sierra Leone & 2.7 & 8.3 & 11 & 7.4 & 13.1 & 20.5 & 7.4 & 9.4 & 16.8 \\
Nigeria & 1.5 & 4.5 & 6 & 3.7 & 7.6 & 11.3 & 5.1 & 8.1 & 13.2 \\
Gambia & 2.3 & 10 & 12.3 & 2.9 & 12.7 & 15.6 & 3 & 15.1 & 18.1 \\
Nyasaland & 0.5 & 9.1 & 9.6 & 4.2 & 10.7 & 14.9 & 3.3 & 8.2 & 11.5 \\
Uganda & 0.6 & 10.2 & 10.8 & 4.1 & 11.6 & 15.7 & 6.3 & 11.2 & 17.5 \\
Kenya & & & & 6.4 & 8.3 & 14.7 & 6.1 & 7.1 & 13.2 \\
\hline BA Average & $\mathbf{2 . 0}$ & $\mathbf{8 . 6}$ & $\mathbf{1 0 . 5}$ & $\mathbf{5 . 1}$ & $\mathbf{1 0 . 7}$ & $\mathbf{1 5 . 8}$ & $\mathbf{5 . 5}$ & $\mathbf{1 0 . 3}$ & $\mathbf{1 5 . 8}$ \\
\hline
\end{tabular}

Sources: For Mozambique see the Orçamentos (1920, 1940) and Fazenda (1930); For Angola the Orçamento (1930) and Conta de Gerência (1940). For British Africa see the dataset of Frankema (2011, Appendix).

\subsection{Extending the mirror}

We will now expand the comparative perspective with the Belgian Congo and French West Africa. If our distinction between jackals and lions is a relevant one, we expect to find the Belgian Congo sharing the basic features of military development - i.e. army size, fiscal burden, coerced recruitment - with Portuguese Africa, while French West Africa would be closer to British Africa. The Belgians had no possibilities to recruit soldiers from other parts of an overseas empire. Unlike Portugal, Belgium was an industrially advanced metropole, but it lacked the geo-political power of nations such as France, Germany and Britain. French West 
Africa (AOF), on the other hand, was part of the larger French empire. The federal government could tap into the military capacity that was already built up in North Africa to transfer military skills and to solve acute security crises. In Algeria regiments of indigenous tirailleurs had been raised and trained since the $1830 \mathrm{~s}$.

As mentioned earlier, the costs of the French colonial army were shouldered by the treasury in Paris. This 'security' subsidy has been a key argument for some scholars to claim that French tax-payers, rather than colonial subjects, bore the brunt of empire (Marseille 1984, Leveuvre 2006). More recently, this debate has received a new impulse with a study by Huillery (2014) showing that the net transfers involved in military spending in French West Africa were only $0.24 \%$ of total French government revenue. Huillery points out that this 'subsidy' facilitated the creation and protection of much larger resource flows in the opposite direction. British tax-payers also paid for a significant part of the imperial security system by taking on the non-negligible bill of the British navy. Davis and Huttenback (1986) have argued that this part of the external defence system especially benefitted the major settler colonies (Canada, Australia, New Zealand), but it also reduced the costs of defence of British dependencies in Africa, Asia and the Caribbean.

The situation in the Belgian Congo was fundamentally different. The regime in the Belgian Congo disposed of a permanent army of ca. 16,000 soldiers during the 1910s and 1920s, which was reduced to ca. 13,000 during the depression of the 1930s. During WWI the numbers were much higher (Annuaire Statistique the Belgique, several issues 1910-1938). Table 4 reveals that both the absolute and per capita size of the Force Publique in the Congo was much larger than in French West Africa. Unlike French West Africa, indigenous tax-payers in the Belgian Congo did contribute significant amounts of money to the military budget. During the early 1920 s, the expenses on the Force Publique comprised about $20 \%$ of the total budget. This share dropped to around $10 \%$ in the early 1930s. Using official exchange rates, we estimate the per capita expenses in 1930 at $0,055 £$, which is comparable to the rates observed in Portuguese Africa and more than double the expenses recorded anywhere in British Africa. ${ }^{88} \mathrm{~A}$ notable difference between Portugal and Belgium is that the former were financially involved in the consolidation of their empire, whereas the Belgium government enforced a strict separation between the budgets of the metropole and the colony, a policy that was rooted in times that King Leopold II ruled the Congo Free State as a private fiefdom (1885-1908), and the Belgian state was not prepared to take on any responsibility for its administrative needs.

${ }^{88}$ In 1930 the Belgian Franc was tied to the British Pound at a rate of 35 to 1. 
One could object that we make too much of the difference between the Belgian Congo and French West Africa, while the differences between British West Africa and French West Africa were substantial as well. Around 1930, the AOF had about three times as many men under arms per 1,000 inhabitants than there were in British West Africa. Moreover, in the early years of the Tirailleurs, the proportion of Europeans to Africans was 1:3, whereas in Nigeria the proportion was 1:26 (Ukpabi 1987, p. 89). This tells us that the lions of imperialism were not equal either. Two aspects are worth mentioning here. First, that the British could exploit the advantages of credible deterrence better, since they had access to an Indian army that dwarfed all other colonial armies and was responsible for the lion's share of imperial cross-subsidies. Second, the French and British developed different policies with regard to the employment of African recruits in times of war. The French used their African forces in many more ways than as a local peacekeeping corps: they supported French war efforts in Africa and fought on European soils during WWI, something which the Colonial Office in London tried to prevent at all cost (Killingray 1979, p. 425).

The implicit subsidies that Indian tax-payers paid to secure the British empire were significant. Throughout the half century between 1880 and 1930 the share of military expenditure in total expenditure (i.e. federal state and the provinces combined) ranged between 25 and 35 percent (Roy 2018). These shares are comparable to Angola up to 1920, but during the interwar years the shares were even higher. If we convert the army expenses into $£$ per capita, the magnitude of the implicit subsidy paid by India, becomes even more impressive. In 1920 alone the expenses entailed about 55 million $£$, on a total population of ca. 306 million. A cost of $0.18 £$ per head was at least twice as much as the per capita costs in Portuguese Africa, while Indian GDP per head cannot have been much higher, if it was higher at all. This was a significant implicit subsidy to the British war effort, and indirectly, also to British colonies in Africa.

To redress this imbalance Winston Churchill, then Secretary of War and Air, wrote to the Chief of the Imperial General Staff in January 1920 that he was "strongly in favour of our beginning to employ African troops from West and East Africa, as well as from the Sudan, for imperial purposes outside the African continent" (cited in Killingray 1979, p. 428). The timing of his letter was no coincidence. The government of British India increasingly resisted against India's status as the lender of last resort in periods of geo-political crisis. The enormous supplies of Indian troops to the war efforts in 1914-18, including services in East Africa, the Middle East and the trenches of Europe, had not only stretched the capacity of this mega-army to its limits, it had also eroded the soldiers' morale to fight for a cause that wasn't really theirs. 
Churchill's proposal to merge the WAFF and the KAR under one command in order to expedite African forces inside and outside the continent was not new. The War Office in London had long been in favour of following the French example of dispatching African soldiers to overseas battle fields, including Europe. However, whereas the War Office saw the potential of an untapped source of military power, that could relief some of the tensions between London and Delhi, the Colonial Office emphasized the problems that this would give: African soldiers would lack discipline and morale, would be confronted with hostility in the Arab world and be unacceptable partners for British or Indian soldiers. Moreover, arming vast additional numbers of Africans would also raise the threat of internal revolts against colonial regimes (Killingray 1979). By WWII, however, the expedition of African regiments to various hotbeds was no longer an issue. Regiments of the WAFF fought against the Italians in Ethiopia, and against the Japanese in Burma. When India gained independence the focus shifted even further towards Africa as the mainstay of the British imperial army.

Another important difference is that the French, Portuguese and Belgians relied to a larger extent on the implicit tax revenues derived from forced labour. Unlike the British, who pressed for reforms of colonial labour policies, these three powers were reluctant to give up their forced labour programs when the ILO in the 1920s started to raise their calls for abolishment (van Waijenburg 2018, pp.49-50). One of the ways to circumvent international legislation against forced labour was to extend a longstanding practice of using army recruits for work on colonial infrastructural projects. The army offered a good cover-up for a continuation of unpaid or underpaid indigenous labour services. This is the main reason why the official statistics of the Portuguese colonies record a dramatic rise in the number of military servants in Angola, with a total registered number of soldiers aged 18 to 30 exceeding 100,000 by the mid-1930s (Anuário Estatístico de Angola 1934-5, p. 299). Indeed, the militarization of Portuguese Africa cannot be seen in disconnect from a long legacy of forced labour recruitment. In British Africa, smaller sized armies were trained on a more consistent and professional basis and were equipped with better weapons and army gear.

\subsection{Conclusion}

We explored the hypothesis that weaker metropoles had to invest relatively heavily in the militarization of their colonies in order to establish and maintain an internal monopoly on violence as well as to sustain their territorial claims against stronger imperial powers. We have argued that Angola and Mozambique could not benefit from the economies of scale, the 
imperial cross-subsidies and the credible deterrence inherent to a global empire governed by a lion power. Military expenses extracted significantly larger parts of the colonial state budget in Portuguese Africa, and this eroded the means to invest in welfare services. Moreover, the size of the armies in Portuguese Africa were larger and recruitment policies relied much more on coercion than on voluntary service. Tentative evidence suggests that the Belgian Congo, another jackal, shared similar features. Although we do not pretend that this study has offered evidence for a generalizable law of colonial state formation that links metropolitan identity to fiscal and military development, we do believe that the key historical data presented above provides us with sufficient suggestive evidence to call for more comparative research on this topic.

Our study has focussed mainly on the implications of differences in geo-political power for the militarization of the colonial state and its implications for the fiscal state. However, there are many more effects that will require attention in future research. One of these is the intricate connection between the organization of colonial armies and forced labour programs. In contrast to the more professional army recruitment practices in British Africa, which tended to be selective and based on monetary compensation, the governments in Angola and Mozambique worked with a system where private companies and local chiefs were the key intermediaries, and contractual conditions were prone to remain a dead letter.

The long-term legacies of these differences have not yet been carefully thought through. Is it just coincidence that of all civil conflicts that broke out after the wave of independence in the early 1960s, the civil wars in Mozambique, Angola and Zaïre/DRC were among the most prolonged and intensive? And what about the long-term consequences of the prolonged interventions in the labour market and accumulated investments in non-productive resources, i.e. young men with arms?

But the most important insight of the comparative perspective we wish to highlight in conclusion is that the imperialism of jackals and lions translated into tangible differences across colonial social orders. These make it extremely hard to separate metropolitan visions or ideologies of imperial governance from the capacity to implement such visions in policy practices. The counterfactual question to scholars - such as Fergusson (2002) - praising the more ‘benign' features of British rule in Africa as being so far apart from the oppressive features of Portuguese colonialism, is what would be left of these principles, when Portugal would have ruled the waves, and Britain would have struggled to prey on the lion's leftovers? 


\title{
Chapter 5
}

\section{'Development' through Coercion. Railway geographies and infrastructural investments in Portuguese Africa, 1880s-1970s ${ }^{89}$}

\begin{abstract}
Railways were key to the colonization of Africa. Railways facilitated the occupation of hinterland areas, the spread of new settlements, the trade in minerals and cash-crops, tax collection and the effectuation of a violence monopoly. From the 1930s onwards, infrastructural investments in Portuguese Africa were increasingly regarded as part of a colonial 'development' scheme. This chapter analyses the emergence of railway geographies in Angola and Mozambique from a political economy and comparative perspective, focussing on the financing, chronological order and operation of different lines and the various actors involved, such as private companies and investors, metropolitan and colonial governments. I show that in the early colonial era railways were funded mainly by private capital - especially in Angola - but the colonial state and colonial budgets soon took over. Both colonies - especially Mozambique - raised indigenous taxes and coerced African labour to fund railway expansion. 'Development' through coercion thus hardly resulted in tangible welfare gains for the impoverished majority of colonial subjects.
\end{abstract}

89 Acknowledgement note: I would like to thank Ewout Frankema, Elise van Nederveen Meerkerk, Filipa Ribeiro da Silva, Nuno Valério and Alexander Keese. I also owe deep gratitude to João Damásio for his assistance in data collection; to the participants of The Annual Conference of Economic History Society at Royal Holloway, University of London (April 2017); to the participants of The Fifth ENIUGH Congress on "Ruptures, Empires and Revolutions" at the Central European University and Corvinus University in Budapest (September 2017) for their insightful comments. Last but not least, I am grateful for the financial support provided by the Netherlands Organization for Scientific Research (NWO) as part of the VIDI project "Is Poverty Destiny? Exploring Long-Term Changes in African Living Standards in Global Perspective". The usual disclaimer applies. 


\subsection{Introduction}

Railways were key to African colonial state building as the most important carrier of bulk transport and the fastest way to move people and troops. Motor and air transport also grew in importance, but only replaced railways after independence. Almost all of the rail serving Africa today, excluding South Africa, was constructed before 1970 (Jedwab and Storeygard 2017, pp.1-2). This chapter investigates what motivated different historical actors in Portuguese Africa, including the metropolitan government, the colonial state and private companies and investors, to invest in railways and how they organized their funding and construction. This chapter also explores the relations between private and public funding and reviews the implications of the establishment of Salazar's regime and the 1930s depression on the changing perspectives of the colonial state on railway expansion, and the adoption of 'developmental' policy programs focussing on infrastructural and agricultural investment programmes, which culminated in formal six-year development plans during the 1950s-60s. Scholars have debated to what extent the ideologies and policies of 'development' have materialized among the majority of the colonial population (Penvenne et al. 2005, p.84; Havik 2013, pp. 169, 176, 204). While this chapter does not provide new empirical evidence to that debate, it does aim to dig deeper into the main features of what I call 'development' through coercion.

Economic historians such as Katzenellenbogen (1973), Vail (1975), Phimister (1981) and Lunn (1992) have studied colonial railways in Central and Southern Africa with a focus on their financing and the political economy of investment decisions. In 1981 Phimister stated that future studies should always situate railways in the context of the political economy at the regional and the global level and "approach railways as an expression of imperialism" linked to settler colonialism and the nature of the colonial state (p.79). This chapter follows this approach, and is the first study to conduct a systematic analysis of railway investment in Portuguese Africa. It thus complements the literature available for British and Belgian colonies such as Nyasaland, Northern Rhodesia, Southern Rhodesia and the Congo.

Compared to other metropolitan powers such as Britain, France, Germany and Belgium, Portugal had fewer financial and human resources at its disposal, and had fewer options to attract funds via state loans at foreign markets. This implied that the potential for infrastructural investment was constrained. However, these constraints do not show up in the comparative size of the railway network in Portuguese Africa, as Table 5.1 demonstrates. 
Table 5.1: Comparative size for railway network in Portuguese Africa and surrounding colonies, 1960

\begin{tabular}{|c|c|c|c|c|c|}
\hline & Railways & Population & Surface & $\begin{array}{l}\text { Railways } \\
\text { km per } 1,000\end{array}$ & $\begin{array}{l}\text { Railways } \\
\text { km per } 1,000\end{array}$ \\
\hline & $\mathrm{km}$ & x 1,000 & $1,000 \mathrm{~km}^{2}$ & $\mathrm{pp}$ & $\mathrm{km}^{2}$ \\
\hline Angola & 3,110 & 5,012 & 1,247 & 0.62 & 2.5 \\
\hline Mozambique & 3,218 & 7,529 & 802 & 0.43 & 4.0 \\
\hline \multicolumn{6}{|l|}{ Bechuanaland } \\
\hline (Botswana) & 634 & 529 & 582 & 1.20 & 1.1 \\
\hline Belgian Congo & 5,074 & 15,451 & 2,345 & 0.33 & 2.2 \\
\hline Nyasaland (Malawi) & 509 & 3,529 & 118 & 0.14 & 4.3 \\
\hline $\begin{array}{l}\text { British East Africa } \\
\text { (Kenya, Tanzania, }\end{array}$ & & & & & \\
\hline Uganda) & 6,558 & 24,974 & 1,768 & 0.26 & 3.7 \\
\hline \multicolumn{6}{|l|}{ Northern Rhodesia* } \\
\hline (Zambia) & 1,036 & 3,138 & 753 & 0.33 & 1.4 \\
\hline \multicolumn{6}{|l|}{ Southern Rhodesia* } \\
\hline (Zimbabwe) & 2,054 & 3,751 & 391 & 0.55 & 5.3 \\
\hline \multicolumn{6}{|l|}{ South Africa } \\
\hline (incl.Southwest Africa) & 20,553 & 16,602 & 2,045 & 1.24 & 10.1 \\
\hline
\end{tabular}

Sources: Length of railway lines from Mitchell (2007), Table F1. Population figures from Frankema and Jerven (2014). Notes: * railway length refers to 1955.

In 1960 the length of the railway network in Portuguese Africa, measured in kilometres per capita as well as territorial surface, fitted neatly into a wider regional pattern, and the network was certainly not smaller than in neighbouring territories, with the obvious exception of South Africa. This suggests that both colonial states were either particularly successful in attracting the interest of private (foreign) investors in order to overcome metropolitan budget constraints, or were particularly effective in raising native taxation and the use of forced labour to maximize investment capacity and minimize construction costs.

As I will argue in this chapter, the persistence of coercive institutions throughout the colonial era, which were only partly relaxed by the end of the Indigenato (colour bar system) in 1958, goes a long way in explaining the political economy of railway construction in Portuguese Africa. The transition to a full-fledged 'developmental state' with increasing public welfare services remained largely incomplete, also due to the rise of independence movements 
in the 1960s-1970s, the ensuing wars of independence and the ultimate withdrawal of Portugal from Africa. Cooper (2002, p.62) and Jerónimo (2013, p.89) have aptly described this phase of late colonialism as a form of "repressive developmentalism".

Figure 5.1. Railway track development in Angola and Mozambique, 1889-1973

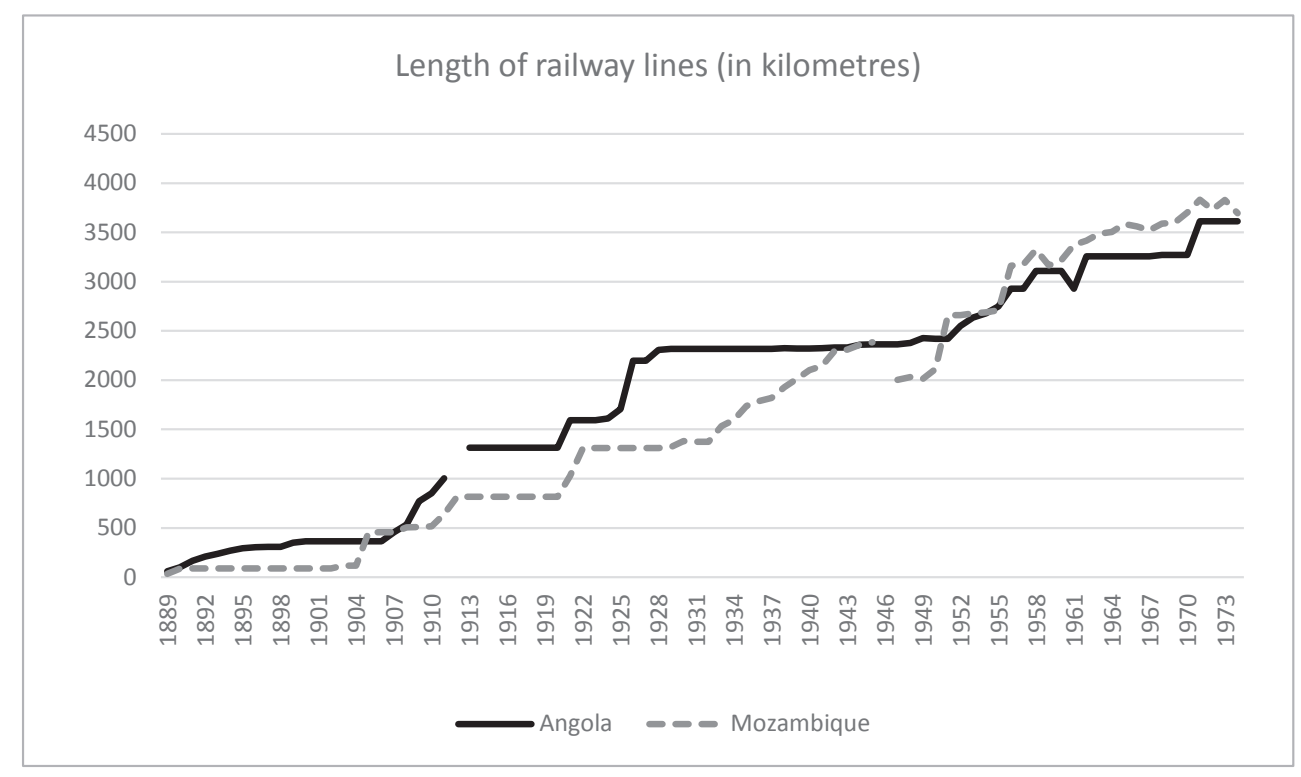

Source: Mitchell (2007), Table F1.

Figure 5.1 shows the size development of the railway network in Angola and Mozambique during the entire colonial era. At the eve of independence the total length approached 4,000 kilometres in both Angola and Mozambique. The figure also shows a stepwise expansion, with Angola taking off earlier and having a big extension in the 1920s, while Mozambique received a similar impulse in the 1930s. By 1940 more than two-thirds of the eventual network was in place. Yet, the network geographies differed considerably. Mozambique had a number of major and minor railways of different length, as shown in the map 5.1, while the Angolan network consisted of just four lines, three major ones and one minor (see map 5.2). These differences are important in our analysis of the political economy of railway construction, as it suggests that the motivations for investment in both colonies may have been rather different. 
Map 5.1: Railway lines in civil-war Mozambique

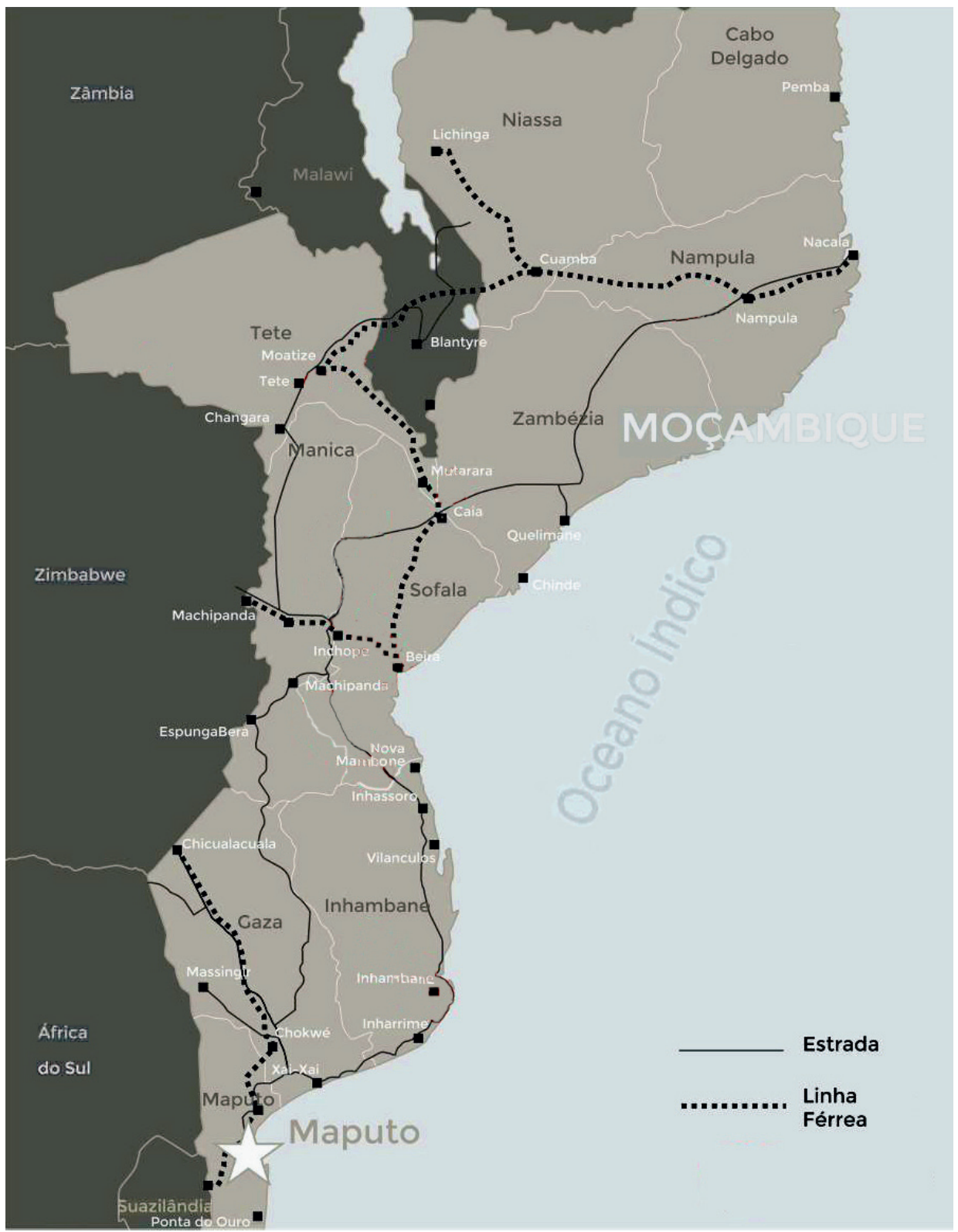

Source of the original map: Rede Angola (2014), Há guerra em Moçambique, http://www.redeangola.info/especiais/ha-guerra-em-mocambique/ 


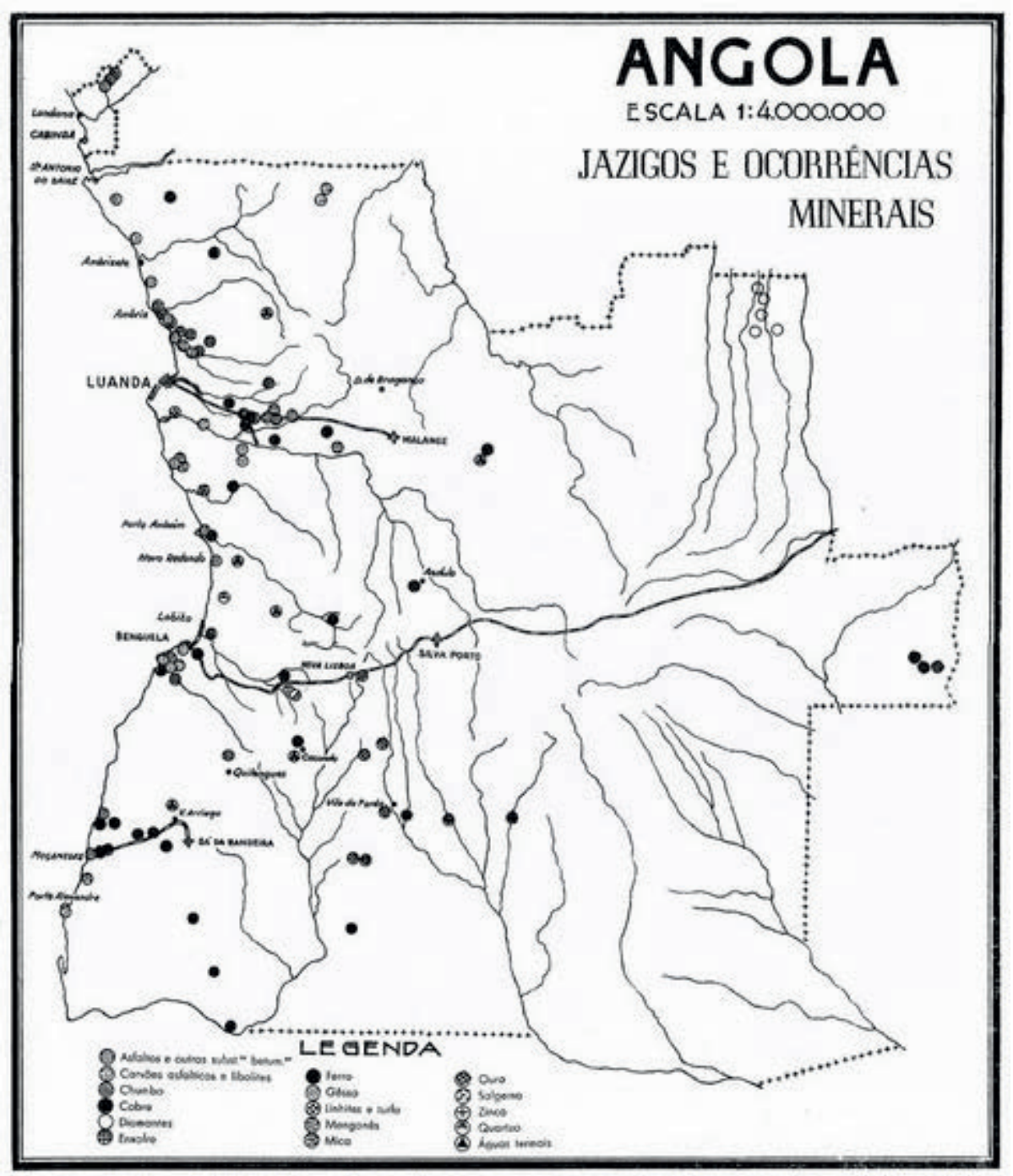

Source: Anuário Estatístico de Angola (Statistical Yearbook of Angola), 1950-51.

This study exploits qualitative and quantitative information on fiscal and labour affairs as well as historical documentation on the construction and operation of railways from primary and secondary sources (administrative reports, statistical yearbooks, accounts and budgets). These documents also provide data on railway traffic (freight and passengers). One of the biggest limitations of the historical sources is the absence of quantitative information on the 
contribution of forced labour to railway construction, which we know has been significant. Still, we will provide - albeit very rough - estimates of forced labour's importance. Annual time series on direct tax revenue and state expenditure, which have been constructed for this thesis, are used to reveal changes in indigenous taxation and infrastructural spending.

The remainder of the chapter is structured as follows: section 5.2 offers a literature survey, section 5.3 provides an overview of the chronological order and main motives of railway construction. I discuss the interactions between various actors involved in the financing of each railway line and investigate the changing roles of private and 'public' capital. Section 5.4 explores the geographies of railways in terms of spatial distribution and accessibility for different groups in colonial society. Section 5.5 reviews the coercive mechanisms present in construction and operation of the lines and section 5.6 concludes.

\subsection{Varying perspectives on railways in colonial Africa}

One of the main debates in the literature on railways in British Africa is on the prevalence of political or economic motives: a demonstration of 'imperialism' or 'capitalism'? Phimister (1974) argued that Cecil Rhodes, one of the key actors in railway expansion across Southern Africa, was best understood as capitalist in his motivation, but later revised his view arguing that the dichotomy itself was a false one. ${ }^{90}$ According to Lunn, "the railway had come to be seen by the British as a means of entrenching and extending empire; the railway became the advance-guard of (British) civilization" (1992, p.239).

A more recent strand of scholarship has studied colonial infrastructures and technologies from a development perspective (Herbst 2000, Jedwab and Storeygard 2017, Jedwab and Moradi 2016, Jedwab et al. 2015) dealing with questions about the long-term legacies of colonial railways. To this end, they have constructed macro-datasets and used econometric analysis to show causal relationships between transportation and various growth-related processes such as commercialization, industrialization and urbanization. Jedwab and

\footnotetext{
${ }^{90}$ Phimister's argument that capitalism and imperialism were interconnected rather than antagonistic is in accordance with Lenin's view on imperialism as the highest stage of capitalism (1917). In the same vein, Luxemburg had already argued in 1913 that imperial powers needed to either sell their surplus to peasants in the form of consumer goods or to governments in the form of capital goods such as railways. To be able to buy consumer goods or pay interest on loans for railways, the less developed countries had to produce and export commodities that the capitalist world needed (e.g. cotton). According to Luxemburg, this need of capitalist countries to export goods to new markets and import raw materials was the driving force for imperialism.
} 
Storeygard (2017) have studied 43 Sub-Saharan African countries during the period 1960-2000 and argued that political and socio-economic drivers mattered more than physical geography for colonial and post-colonial infrastructure investments. The authors point in particular to levels of historical state centralization, ethnic fractionalization, the share of European settlers, democracy and exports of natural resources (ibid, pp.20-26). Jedwab et al. (2015) and Jedwab and Moradi (2016) showed how the construction of the colonial railway network in Kenya and Ghana determined the location of European settlers and the development of cities over the following decades (ibid). To connect the coast with the mining centers in the hinterland, the British colonial state built railroad lines which passed through lowly populated forest areas. Gradually these areas attracted rural populations, due to the decreasing costs of domestic trade and the facilitation of cocoa cultivation and export. According to the authors, these colonial urbanization trends persisted throughout the post-colonial era (Jedwab and Moradi 2016, pp.12). However, in Africa urbanization did not always enhance growth (Fay and Opal 1999). ${ }^{91}$

In their recent study of the Cape Colony, Herranz-Loncán and Fourie argue that the Legislative Council viewed railways neither as a political or military tool, nor as a source of public revenue. They concluded that railways were viewed as a means to open up and develop particular areas $(2017$, p.74). They have also shown that the benefits from the expansion of the railway network in Cape Colony were not evenly distributed. The railways served the minebased economy, "probably benefitting those groups, such as the mine owners and farmers of the Western Cape, whose interests were best represented in parliament" (ibid, p.75). Earlier, Pirie (1993) had also identified the start of gold mining and the dawn of the railway age in southern Africa as interconnected realities.

In both academic discussions and public discourse, technological innovations or adoptions - such as railways - are often perceived as neutral external shocks that contribute to a lesser or greater extent to economic development. However, technological innovations are not adopted or implemented in a vacuum. They reflect established or newly emerging power relations and shape social transformations. Scholars such as Esteves $(2000 ; 2008)$ and Madeira Santos (2008) have brought processes of spatial integration and marginalization to the fore. For

\footnotetext{
${ }^{91}$ The relationship between infrastructural development, urbanization and living standards has also been questioned in the case of early industrialized Europe and America (Baten and Fertig 2009, Komlos 1987). Baten and Fertig (2009) argue in an anthropometric study that the extensive use of railways in the highly industrialized Ruhr district in Germany facilitated the export of the protein-rich agricultural production (milk), which forced farmers and their children to consume low-quality import food. The infrastructure improvements and the subsequent income generation instead of fostering the general welfare of the rural areas, harmed the health of farmers and their children, at least in the short run. In this sense, market integration and transformation of rural areas led to rising nutritional inequality, expressed via lower heights in the lower social strata groups such as day labourers (ibid, pp.263-266).
} 
Madeira Santos the construction of railways was an integral part of Portuguese imperialism, which reduced political and economic power of Africans (2008, p.9). Esteves shows the controversial reactions of Africans towards the introduction of foreign technologies, ranging from fear to admiration, arguing that economic potential did not always stimulate the adoption of new means of transportation (2008, pp.10-11). Hostile attitudes dominated especially in the early phases of colonial rule. Traumatized by experiences of violent coercion railways and roads were simultaneously seen as representations of wealth and poverty, of liberation and repression, and of unification and fragmentation (ibid, p.14). ${ }^{92}$ The title of this study also points to this inherent contradiction.

In the eyes of early colonial officials new means of transportation in Portuguese Africa would encourage trade and industrialization as well as boost general prosperity (Dias Costa, 1898, p.10). Chilundo (2001) offers an in-depth study of railways and roads in Nampula (northern Mozambique), shedding light on the role of the Portuguese state, the concession companies and peasants as construction labourers. His study shows that the colonial government of Mozambique aimed to outsource construction and investment costs, especially during the early colonial era, but this strategy often failed. This study treats these issues at a macro-comparative level, by looking at changes in the financing of railways in the entire areas of Mozambique and Angola, because investment decisions are usually influenced by both regional, 'national' and transnational factors. As we will see in the next section, in the case of Portuguese Africa transnational developments - i.e. in neighbour colonies - were especially important.

\subsection{Railway construction and operation: Priorities of private capital and colonial states}

In 1877 two Public Works Expeditions were conducted in African territories under Portuguese administration, aiming at assessing the potential for railway construction, starting from the two

\footnotetext{
${ }^{92}$ Railways also had negative side effects such as the easier spread of diseases. The increase of traffic across certain caravan routes caused large fluctuations of population and facilitated pandemics (Esteves 2008, p.24). This is in accordance to the findings of scholars who have studied the "antebellum puzzle" and the (paradoxical) impact of urbanization, commercialization and technological change -including transport revolution- on growing inequality and deteriorating health conditions in $19^{\text {th }}$ century England, the Netherlands and the United States (Haines 2004). For instance, the increasing dependence of people on wage income and the frequent use of railways, which transferred unhealthy micro-organisms from the urban to the rural areas, made rural populations more vulnerable. Eventually (between 1830-1880), the integration of disease environments affected welfare and resulted in a downturn in heights (ibid, p.252). The comparison with Europe shows that in various regions the benefits and costs of railways were not equally spread among the population. Social class and power relations mattered not only in a colonial context but also in the context of metropolitan cities.
} 
principal port cities of Luanda in Angola and Lourenço Marques in Mozambique (Diogo and van Laak 2016). As the scramble unfolded, railway planning gained high priority. In general, there were three interconnected motivations for railway investment: first, to facilitate transport of commodities from the hinterland to coastal ports, or to surrounding colonies. Second, to facilitate effective occupation of and control over extended hinterlands, and clear the ground for new settler communities. ${ }^{93}$ Third, to integrate colonial subjects into the fiscal system through both taxation and development expenditures, and to increase commitments to and consent for colonial governance.

Another motivation was that railways were a potential source of income for private and chartered companies as well as colonial administrations, but their profitability was in many cases hard to assess ex-ante and many lines made significant losses. Some railways were built by foreign private capital, occasionally after the initiative of neighbouring countries - e.g. The Belgian Congo, South Africa - while others were financed and built by the colonial governments of Mozambique and Angola, with or without the financial support of the metropole via loans or subsidies. In general, there existed a relation between the conceived purpose of the line, its financial backing and the speed of its construction: the larger the ex-ante estimated benefits, the more likely the line was funded by private capital and the faster it was built and taken into operation. The best examples are the lines that connected major mining enclaves to the coast.

The operation of railways also triggered major socio-economic, spatial and cultural transformations, such as the integration of African tribes into commercialized agriculture and the shift from tropical commodity trade to cash-crop economy. A prominent example are the Ovimbundu, who inhabited Bie in central Angola and were profoundly affected by the Benguela railway on the eve of the $20^{\text {th }}$ century. Via the frequent use of the railway, the Ovimbundu got acquainted with maize cultivation and "civilised life" (McCulloch 2017, Heywood 2000), while before they were employed as human porters and/or rubber traders.

Transnational conditions also added to the political economy of railway construction. Some railways served the commercial and military interests of Great Britain and South Africa. The railways in Mozambique thus became "mainly located along the corridors linking the southern area around Maputo to South Africa and the central regions to Zimbabwe" (Tornimbeni 2005, p.308). Railway-building also absorbed vast sums of British investment

\footnotetext{
${ }^{93}$ From about 1930 onwards army mobility also increased due to the emergence of new means of transportation (cars and trucks) and communication systems (da Silveira 1938). Because of the extensive use of railways by Portuguese troops, lines such as Benguela Railway in Angola were also popular targets for sabotage by independence movements UNITA and MPLA in the late 1960s (Duarte 2014).
} 
capital throughout the mid- and late 19th century (Lunn 1992, p.239). ${ }^{94}$ The British South African Company outsourced the construction cost and the responsibility for operating the lines as much as possible. Railway construction was realized with loans in the shape of debenture shares. "Debenture-holders were entitled to fixed, regular and pre-determined payments of interest under guarantee" (Lunn 1992, p.245).

Havik mentions that in the early 1920 s investments in railroads, ports and roads in Portuguese Africa "were largely funded by private credit" (2013, p.178). Nevertheless, in Mozambique about 1,390 km of railway track was funded by the colonial state, while only 655 $\mathrm{km}$ were funded by private companies. As tables 5.2 and 5.3 show, two thirds of the railway lines in Mozambique were constructed and operated by the state (Vasconcelos 1948, p.26). In Angola, two of the four principal railways were at least partially constructed by companies. Yet, the construction and operation of the Luanda railway (i.e. the $2^{\text {nd }}$ most important line in Angola) was taken over by the state at a very early stage (1903).

\section{Railways principally constructed by private capital $^{95}$}

In the period 1840s-1880s several Portuguese and British investors made speculative proposals to construct railways in African territories, but these proposals were either never completed or were rejected by the local government (Pereira 2017). Also, many concessions, that were initially approved, failed later on.

94 "The Rhodesian railway system was built into an economic void; [...] traffic was initially minimal if not non-existent. Other 'pioneer' railways of the time within British Africa, with the exception of the Nyasaland Railways, were built by imperial governments rather than Chartered Companies for this very reason" (Frankel 1938).

${ }^{95}$ Often the metropolitan government, the colonial state, individual investors and private companies cooperated for the construction of railways and the exact amounts invested by each actor are not always known. I assess which railways were principally funded by private capital (foreign, metropolitan or domestic) or by colonial states, based on evidence from primary and secondary sources. However there are controversial cases such as Lourenço Marques and Luanda Railway, which could fit both categories. Also, we need to keep in mind that private capital was involved more in the construction process than in the operation of railways, while the colonial states took over a prominent role mostly after the first lines had been constructed, by managing the network's extension and operation. In this chapter I analyse railway investments from a comparative political economy perspective, involving both spatial and temporal dimensions in the analysis. I shed light on the relationship between private capital and colonial states, and at the same time highlight local geographic conditions of Mozambique and Angola as well as change over time. 
As shown in figure 5.1, in Angola four separate, unconnected, coast-to-inland railway lines were constructed and operated during the colonial era (1880s-1970s). Two of them were constructed by chartered or private companies: the Benguela Railway by Companhia do Caminho de Ferro de Benguela (CCFB) and the Luanda Railway. However, the latter passed under the control of the colonial state at a very early stage (1903). In the 1900s Luanda and Benguela were the only cities that existed in the colony. As late as 1948 Benguela Railway stopped being in deficit and in 1954, after fifty years of activity, distributed the first dividends (Silva 2008, p.20).

The most profitable lines in the southern and central zones of Mozambique were built by concession and private companies. The Beira Railway was aimed to boost the transit trade from and to South Africa, while the Lourenço Marques Railway also enhanced labour migration from the southern zone of Mozambique to the gold mines in Transvaal. In most cases, the budget of railways was balanced or even produced surplus (revenue exceeded expenditure). The cases that presented considerable deficits (expenditure exceeded revenue) were usually taken over by the states. In particular, the rail network of Lourenço Marques (today Maputo) produced surplus which covered the deficits of other lines in Mozambique (Vasconcelos 1948, p.27).

\section{The Benguela railway}

The discovery of copper deposits and the start of mining operations in Katanga provided the main rationale for the Benguela railway. The Caminho de Ferro de Benguela (see map 5.3) started construction work in 1903 and by 1912 the line linked Lobito (the port) and the city of Benguela with Huambo city (formerly Nova Lisboa). By 1929, it was extended to Dilolo in the Congolese copperbelt. The Benguela Railway was the brainchild of Sir Robert Williams, the managing director of Tanganyika Concessions, a company with extensive mining, property and financial interests in Central Africa. Williams was an engineer and entrepreneur (and also an associate of Cecil Rhodes) and he realized that a faster route to European and American markets was required. He viewed Lobito, on the coast of Benguela Province, as a perfect ocean-outlet. The line would then be linked to the existing railways of the copperbelt in the Belgian Congo and Northern Rhodesia, and run inland for a distance of ca. 1,345 km (Varian 1953).

In 1902 Williams received a 99-year concession from Portugal to build and operate the Caminhos de Ferro de Benguela (CFB). Tanganyika Concessions Ltd. supplied about 90\% of the initial capital investment of three million pounds, while the rest was provided by the 
Portuguese government and a few private shareholders (Hance and van Dongen 1956, p.466). ${ }^{96}$ The railway company remained in private hands and had shares listed on the London Stock Exchange. After the expiration of the concession in 2001, the railway has been owned by the Angolan government.

\section{Map 5.3: The Benguela Railway (n.d.)}

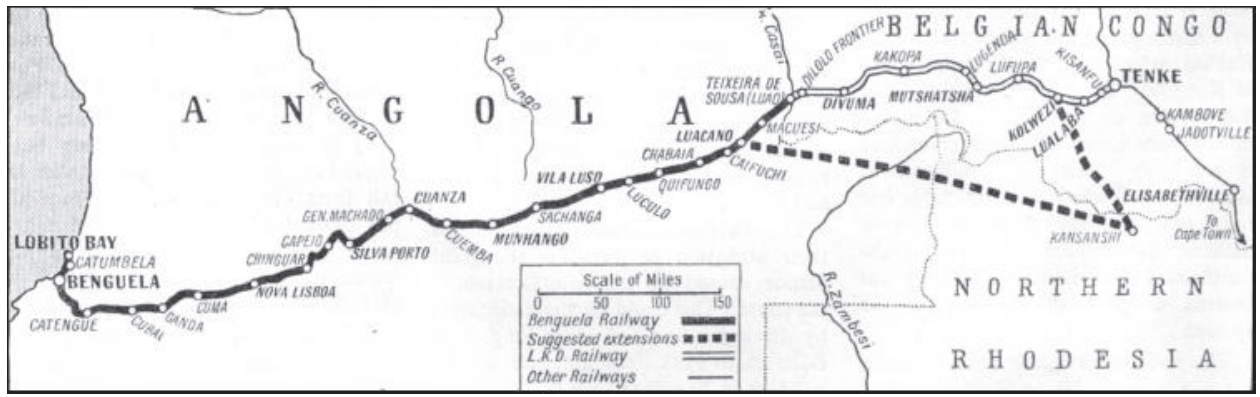

Source: This map is retrieved from Mike's Railway History, Across Africa by Rail, http://mikes.railhistory.railfan.net/r011.html

Prior to the opening of the line from Lobito to the Congo border in 1928, the transport of minerals (mainly copper) went via the port of Beira in Mozambique, via the Victoria Falls Bridge and Southern Rhodesia; a much longer route to Europe, as ships had to sail around the Cape. The introduction of railways and later motorized transport also had advantages for African merchants, who could now avoid the danger of running out of food while crossing the "Hungry Country", which was feared in the days of native-carrier transport (Varian 1953, p. 168). An advertizing brochure of the Benguela railway in the early 1930s stated,

"for European shippers and manufacturers it is unquestionably the quickest and most economical route to the territories served, the saving in time and transport charges representing a considerable reduction in the landed cost of goods in Central African markets" (Benguela Railway brochure, n.d.).

\footnotetext{
${ }^{96}$ Sir Joachim José Machado, the general governor of Mozambique, became the first managing director of CFB. This is an example of colonial administration and company management being highly interconnected.
} 
Yet, a lack of rainfall and general water scarcity formed a major obstacle for the extension of the line beyond Huambo as it complicated the logistics of railway construction and created extremely harsh conditions for labourers (Silva 2008, p.4). Further delays were caused by disrupted supplies of materials and labour during WWI. After the war delays were caused by South African opposition. Jan Smuts, Prime Minister of South Africa between 1919 and 1924 was strongly against the CFB connection to the Congo, on the grounds that it would take away traffic from the line routed through Southern Rhodesia.

\section{Lourenço Marques, Beira, Trans-Zambezia and Quelimane railways}

The first railway line in Mozambique opened in 1890 and connected the capital Lourenço Marques with the border-town Ressano Garcia (see map 5.1). To ensure the safety of the rail traffic, the Portuguese army occupied the Gaza Kingdom in Southwest Mozambique. In 1895 the railway was extended across the border in Transvaal (today's Pretoria). The so-called "Delagoa Bay Railway" was constructed by the Netherlands-South African Railway Company (Nederlandsch-Zuid-Afrikaansche Spoorwegmaatschappij, NZASM) in cooperation with the Portuguese government and was soon taken over by the colonial government of Mozambique. ${ }^{97}$

In 1887, Henrique de Macedo stressed the importance of the railway for the trade economy and the social conditions of the people (Lima 1971, Vol. I p.32). The capital used for the line's completion derived mainly from metropolitan resources. However, the replacement of the line and the construction of variantes (branches) at a later stage were funded by the budget of the district of Lourenço Marques (ibid, p.195). After the unification of South Africa in 1910 and the availability of other ports, Lourenço Marques was no longer the most preferred port. Nevertheless, the railway remained heavily used and profitable, especially due to coalrelated traffic from Transvaal (Vasconcelos 1948, p.5).

\footnotetext{
${ }^{97}$ To avoid the English ports in the Cape and Natal, the Boer Republic of Transvaal tried to obtain access to the sea via Lourenço Marques already in 1835, but these attempts failed. The idea of constructing a railway to Lourenço Marques revived in 1870, when the newspaper Volksrad called it "the railway of progress" (o caminho do Progresso) as it would serve as a major alternative to the use of badly maintained tse-tse infested roads which posed a constant threat to cattle and travellers (Vasconselos 1948, p.4). In 1876 President Kruger negotiated with Portugal on the construction of the railway and in 1883, after the independence of the Boer Republic from English occupation, a concession was granted to the American investor McMurdo. When the concession was ended in 1890, the line was completed by the Portuguese government (ibid). In 1883 J.J. Machado (later governor of Mozambique) became the director engineer and in 1884 the construction continued with a few interruptions due to the opposition of English colonies (ibid, p.5).
} 
Work on the Beira Railway in central Mozambique began in 1892, after a contract was signed between Portugal and Britain to connect the Mozambican port of Beira with Salisbury in Rhodesia (today Harare in Zimbabwe), "where the settlers were in urgent need of better communication than that afforded by the ox-wagon" (Varian 1953, p.37).$^{98}$ By 1900, the line was in service and run by the Mozambique Company as part of her 'royal privileges' in the districts of Manica e Sofala. The line crossed the rivers Pungué and Revué via bridges and was linked to the Rhodesian rail network operated by the Rhodesia Railway Company (Vasconselos 1948, p.21). The Beira railway produced a large surplus which was managed by the Mozambique company until 1949, when it came under the control of the colonial state (Lima 1971, Vol. II, p.165).

The Trans-Zambezian Railway crossed the Zambezi, the longest river in Eastern Africa, and linked the port of Beira to Nyasaland (today Malawi). After Livingstone's explorative journeys in the $1880 \mathrm{~s}$, the Zambezi river was considered to be the principal penetration route into Central Africa. In 1891 Portugal signed an agreement (Modus Vivendi) with Britain which secured the international navigation of the Zambezi and Shire rivers, so that passengers and commodities from Mozambique could be transferred to Nyasaland (Lima 1971, Vol.II p.190). However, waterway transport had certain disadvantages; the humidity and the insects harmed agricultural products such as cereals. In 1894 J.J. Machado, the governor of Manica e Sofala, ordered the preparation of a railway study plan. In 1898 an agreement was signed between Mozambique Company and engineer Leopold Auguste Henri Porcheron, who was granted the right to construct a railway line between Beira and a bridge starting from the southern bank of Zambezi river. Due to the regime change in Portugal (fall of Monarchy in 1910), the project was delayed (Lima 1971, Vol. II p.169). In 1912 all rights were transferred to Compagnie du Chemin de Fer de Beira au Zambeze, which in turn sold its concession to a new company. In 1919 a new contract was signed between representatives of the overseas British colonies and Trans-Zambezian Railway Company.

\footnotetext{
${ }^{98}$ Due to the South African War in 1899 all traffic (both passengers and goods) from Rhodesia was diverted through Beira railway and port. Troops of about 7,000 mounted Australians, New Zealanders and Canadians were transported and still there was a growing concentration of men on the shore waiting for transport (Varian 1953, pp.42-43).
} 


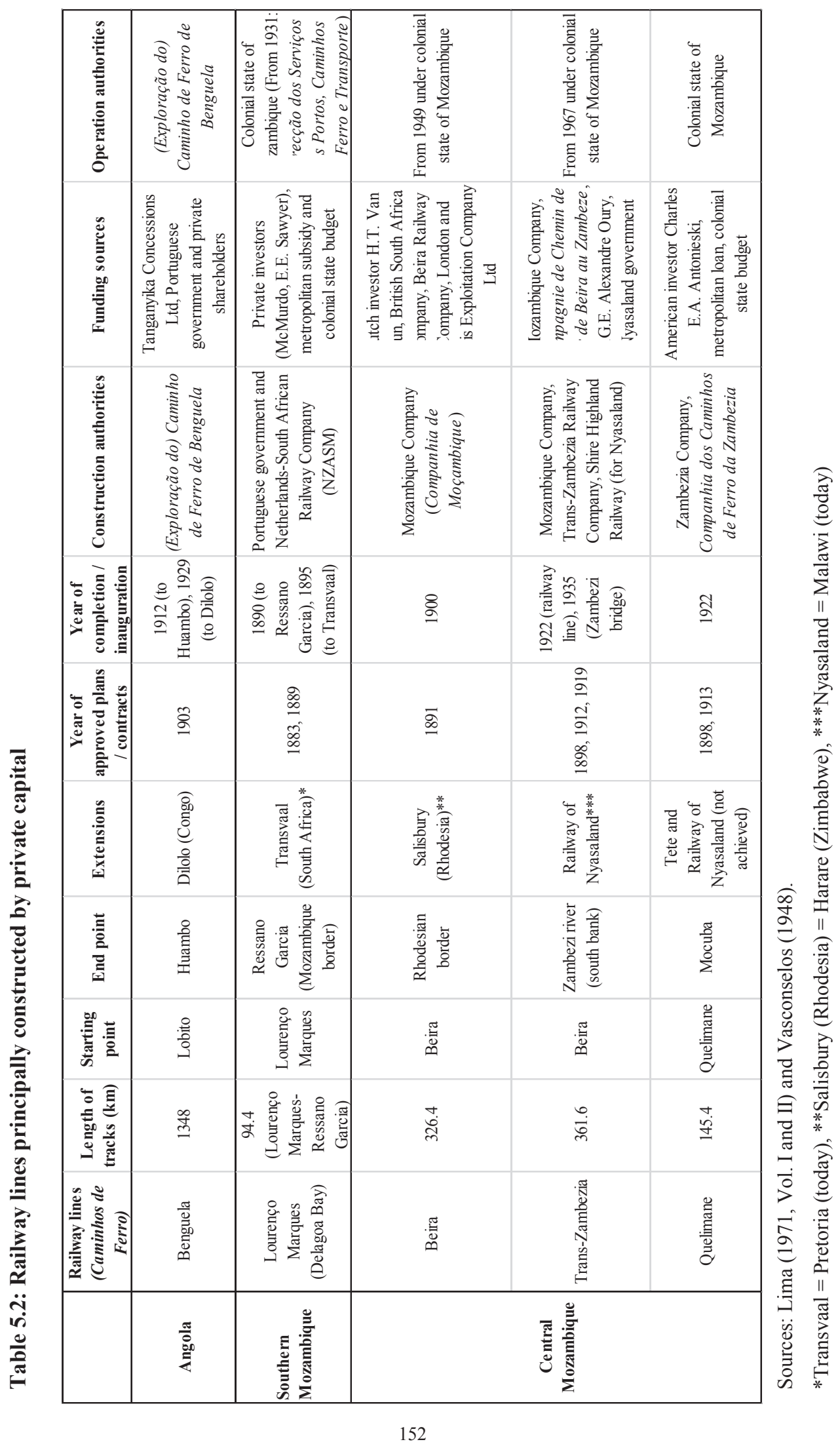




\section{Image 5.1: The end of the railway at Zambezi river in Mozambique, 1931}

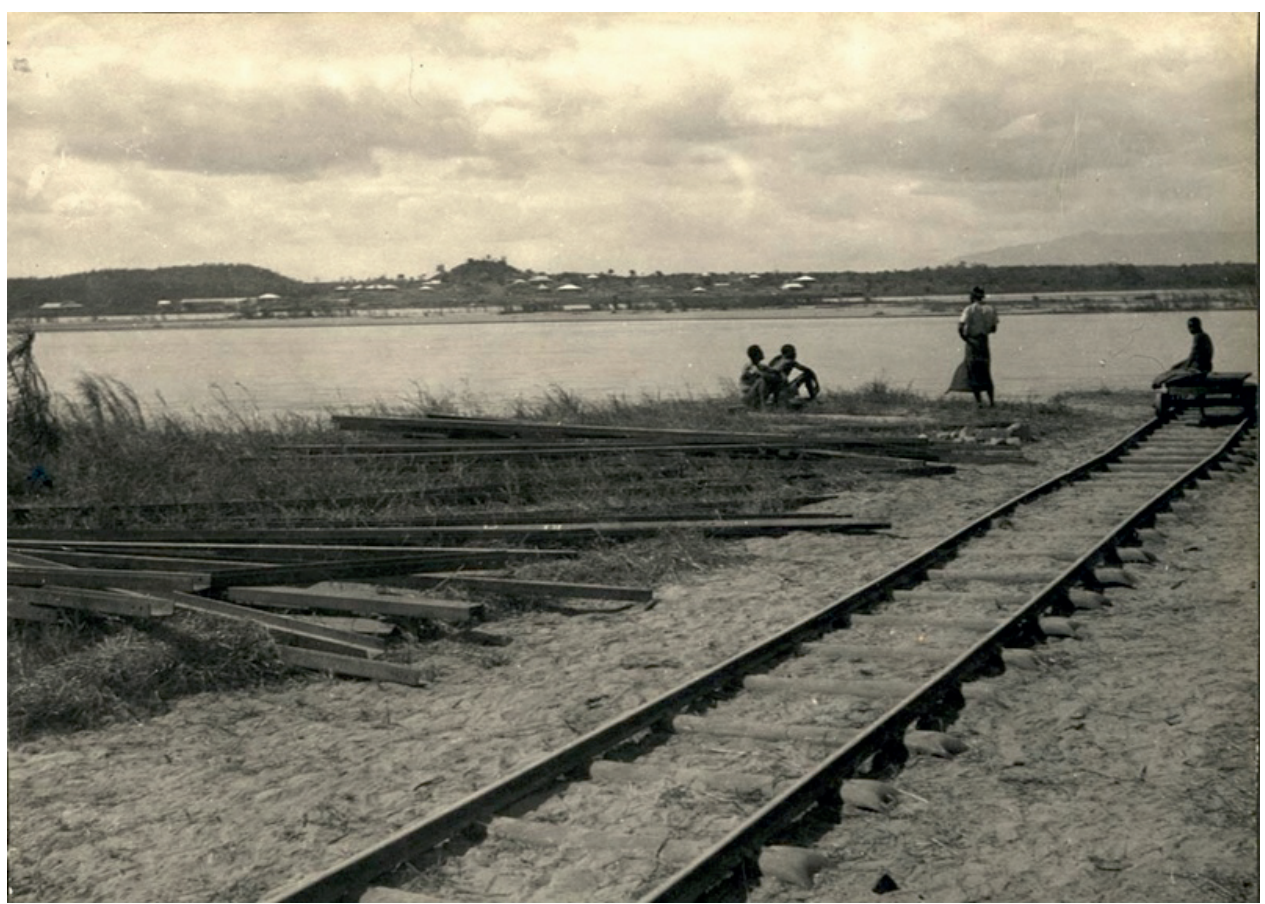

Source: The Delagoa Bay Review (2012, 13 March). A História da Ponte Dona Ana,

https://delagoabayword.wordpress.com/category/arquitectura-mocambique/historia-da-ponte-dona$\underline{\text { ana/ }}$

The line was completed in 1922 and thirteen years later a massive railway bridge across the Zambezi opened to traffic (White 1993, p.16). ${ }^{99}$ The Zambezi bridge was characterized as "the greatest work of art in all Africa" and later became a major tourist attraction (ibid, p.187). In 1930 Portugal granted Shire Highland \& Railway Co Ltd. the right to extend the line into Nyasaland (Lima 1971, Vol. II p.172). The Trans-Zambezian was managed by the concession Company of Mozambique until 1967, when the bridge of Zambezi was sold to the Portuguese government $^{100}$. The government obtained $93 \%$ of the stocks of Trans-Zambezia Railway Company and in 1968 the line passed under the administration of Direcção dos Serviços dos Portos, Caminhos de Ferro e Transportes. The line was profitable in most years and surpluses

\footnotetext{
${ }^{99}$ In 1986, part of the bridge was blown up by RENAMO (ibid).

100 Often the Portuguese metropolitan government and the Portuguese colonial government are undistinguished in both primary and secondary sources of the colonial era (i.e. administrative reports).
} 
increased especially after WWII, when economic growth in Central Africa gained momentum (ibid, p.174).

In 1887 a concession was requested by the colonial state of Mozambique for building a line from Quelimane on the Indian Ocean coast north to Mocuba, In 1895 the Companhia dos Caminhos de Ferro da Zambézia declared that it did not have sufficient funds to build it (Vasconselos 1948, p.12). In 1898 the colonial government offered the company a loan to initiate the construction. Press reports in the 1900s claimed that the railway was a sine qua non condition for the development of Central Africa, especially because of African and European maize cultivation (Central African Times, 1906 February 3). In addition, cotton exports and the imports of agricultural and industrial instruments were rising, alongside with direct tax revenue from indigenous farmers. The colonial state considered the building of a railway in the region not only desirable but also feasible (Lima 1971, Vol.II p.217).

The Quelimane Railway was part of the vision of establishing permanent white settlements in regions of high altitude, where the climate was good. The population ratio of that time was only 600 white settlers per one million Africans and colonial officials questioned whether Mozambique could be described as a "settler colony" (ibid, p.218). In 1913 the construction of the line was authorized by the government and the idea of extending it to Tete and linking it with Nyasaland rail network was also discussed. The line opened in 1922 and served the agricultural and mining centers of Quelimane district, north of Zambezi river (Vasconcelos 1948, p.13). Due to soil difficulties, the line terminated in Mocuba, without achieving its initial objective of reaching Tete and Nyasaland border. Quelimane railway ended up being a minor regional line when the Trans-Zambezian was built (Lima 1971, Vol.II p.212). Its budget in the 1940s was balanced or ran small deficits (Vasconselos 1948, p.14).

\section{Railways principally operated by the colonial states}

Sizeable investments in the exploration and construction of railways in Portuguese Africa were also funded through metropolitan loans and colonial state budgets. In Angola, the two minor lines were constructed and operated under the authority of the colonial state. The Mossamedes Railway was managed by the state-owned enterprise Caminho de Ferro de Moçâmedes and the Amboim Railway was managed by the Luanda Railway, which had been taken over by the government before the construction of the Amboim line. In Mozambique the majority of lines were constructed and operated by the colonial state, and those initially funded by private capital were all passed on into state hands before independence (the latest in 1949 and 1967). Six years 
after the coup d' état in Portugal (1926), the Directorate of Ports, Railways and Transport was created and fostered the administrative unification and 'nationalization' of the railway network. By $1945,75 \%$ of the total revenue derived from railways was already captured by the colonial state.

\section{Railways of Luanda, Moçâmedes and Amboim}

In 1885 the Angolan government authorized a public competition for the construction of the Luanda and Ambaca line (Caminhos de Ferro de Luanda). In 1886 the contract for a trust (curadoria) was signed in London with the Construction Society ${ }^{101}$ to explore and construct the line (Questão do Caminho de Ferro de Ambaca 1913, p.3), while the state would take care of transport equipment (ibid). In 1888 the first part of the railway line from Luanda to Funda was inaugurated. Contracts were extended in the period 1891-1902. The Trans-Africa Railway Company was increasingly criticized in the public discourse for obtaining exceptional privileges at the expense of tax-payers (Ministerio dos Negocios da Marinha e Ultramar 1909, p.5). From 1889 the metropolitan government spent approximately 9 million Reis -plus 3 million Reis on increasing debt service- and the colonial treasury of Angola spent an additional 5.5 million Reis (ibid, p.6). While the TARC in Portugal was mainly accused for spoiling state subsidies, in Angola complaints focussed on excessive tariffs and poor train schedules (ibid, p.20). ${ }^{102}$

From 1903 onwards the colonial state controlled the construction process (Direcção do Caminho de Ferro de Loanda 1909, p.29). By 1909, the Luanda rail line was extended eastwards to Malanje by the state. The official report by the Director A.A. de Andrade states that the principal commodities transported were alcoholic drinks (aguardente), agricultural

\footnotetext{
${ }^{101}$ The Construction Society consisted of the same people who emerged in 1886 as shareholders of the Trans-Africa Railway Company (Companhia Real dos Caminhos de Ferro Através de África).

102 The Company replied to the critics with extended reports, in which it argued that there was no favouritism involved, the terms of the concession agreement were respected (the state had agreed to offer the interest guarantee to the Company) and the suggested solution to deliver the railway to the colonial state was unjust (ibid, p.7). Also, the Company pointed at the lack of initiatives from the side of the metropole to improve the conditions in Angola and claimed that the debt of the state towards the company was high (ibid, p.13). Last, according to the Company, the state was too optimistic about the magnitude of the commercial activity in the region (that would justify the investment), due to the promises of local authorities to promote regional trade. The line aimed to serve the rich councils of Cazengo, Golango Alto and Ambaca, so it was hoped that the collected revenue would cover the exploration expenses and the government would pay only the interest on the construction expenses (Relatório da Companhia 1889, p.14).
} 
tools, guns, rubber and wheat flour (República Portuguesa 1910). The busiest station, that brought most of the revenue, was Lucalla in Cuanza Norte inhabited by white settlers (ibid, p.48). The railway produced surplus the first year under state control.

However, the construction of the Ambaca branch proved to be a "financial disaster" (Pimentel 1892, p.213). On the inauguration day the Governor of Angola, Joachim d' Almeida e Cunha, described it as an investment in luxury rather than commerce: "a truly European and not an African railway" (Ministerio dos Negocios da Marinha e Ultramar 1909, p.25). According to the press of that time, the traffic of the line was very low (no passengers and almost no commodities transported) due to the repelling tariffs (Dia 14.3.1900).

The debate on the construction of more variantes (branches) flared up in the 1920s with initiatives to go beyond Malanje and open up the Bengo and Cuanza valleys. Some opinion makers argued that the costs to tax-payers were excessive (A Provincia de Angola 4.8.1924), and the commercial potential too small. In their view, investments should be made in the region where diamonds were extracted (ibid). The engineer Gonçalo Cabral clarified that the new line served cotton and coffee plantations, while the valley areas crossed by a river were easily irrigable for sugar and rice cultivation as well. But in his effort to discard the complaints, he also admitted that the line was 'a penetration line' aiming to access the partially controlled hinterland (Cabral 1924, pp.29-30). The Governor of Angola, Paiva Couceiro, in his 1907-1909 report classified all three main railways of Angola, including Benguela, as penetration lines (ibid, p.30). Effective occupation thus appeared as the principal motive of the Portuguese officials for constructing railways in Angola.

The second significant line, the Mossamedes Railway (Linha de Moçâmedes), connected the port city of Mossamedes (today Namibe) in the south of the colony with the inland town of Serpa Pinto (today Menongue). It was built and operated as a state railway right from the beginning. In 1910, the first section of the line opened to traffic (Durrant et al. 1981) and in 1923 the railway reached Sá da Bandeira (today Lubango). It aimed to link the port to the plateau of Chella, where the climatic conditions and the quality of land were suitable for large agricultural production (especially cotton) and livestock keeping. Apart from the railway's economic advantages, there were also political and strategic motives to build it such as its significance for military operations and intense European colonization. The Portuguese government presented to the parliament a law proposal to authorize a loan of 1,5 million Reis (Direcção dos Serviços dos Portos, Caminhos de Ferro e Transportes 1949, p.5). In 1948 the extension started to be constructed, directing further to the rich regions of the south (ibid, p.3). The line linked two of the most densely populated and homogenous centres of colonial activity. 
Finally, a smaller railway line was built to connect Gabela, the richest region of coffee plantations on Amboim plateau, to the port of Amboim. The first $80 \mathrm{~km}$ were inaugurated in 1925. The Amboim-Gabela line was managed by the Luanda Railway, which from 1903 was under state control. It was considered as part of Angola's central railway spine (espinha ferroviaria) and served the growing plantation economy.

\section{Limpopo, Inhambane, Gaza, Tete and Moçambique railways}

The railway to Limpopo in southern Mozambique started with a line between Moamba and Xinavane, and was constructed by a private company on behalf of the state. The first stretch was inaugurated in 1914, and only in 1957 the line was extended to the Limpopo valley. The initial line served an important sugar processing plant, the extension was serving the cotton producers of the Limpopo valley, which benefited from large irrigation works in the 1940s (Vasconcelos 1948, p.9). The ultimate goal of the railway was to lure new settlers from Portugal to the region. According to the official reports, the line produced a neat surplus.

The lines of Inhambane and Gaza also targeted agricultural exports. The construction of the Inhambane railway was concessioned by the government already in 1898, but the Inhambane Company did not realize its plan to connect the Inhambane port to the border of Transvaal as it failed to discover the expected mineral deposits along the line. The line reached Inharrime in 1912 under the control of the colonial state. It served the transfer of mafurra and in the 1940s it faced substantial deficit (Vasconselos 1948, p.11). ${ }^{103}$ The line of Gaza which opened in 1915 connected the airport of Chai-Chai to the agricultural areas of the Manjacase. This line also made losses (ibid, p.10). ${ }^{104}$

\footnotetext{
${ }^{103}$ Mafurra resembles cocoa butter and derives from a type of Eastern African tree.

${ }^{104}$ Moreover, from 1903, a $54 \mathrm{~km}$ long line was constructed from Lourenço Marques to Goba, on the border with Swaziland, so that the British colony could export her natural resources. The construction was completed in 1912. The extension of the line starting from Machava to Ressano Garcia was discussed, after the request of Lord Milner (High Comissioner of South Africa). However, the proposal provoked opposition in the Union of South Africa, due to the observed decrease of traffic in the local port of Durban. This line offered a shorter link to Rand mines, serving the western region of Transvaal. In the 1940s it produced considerable surplus (Vasconcelos 1948, p.7).
} 


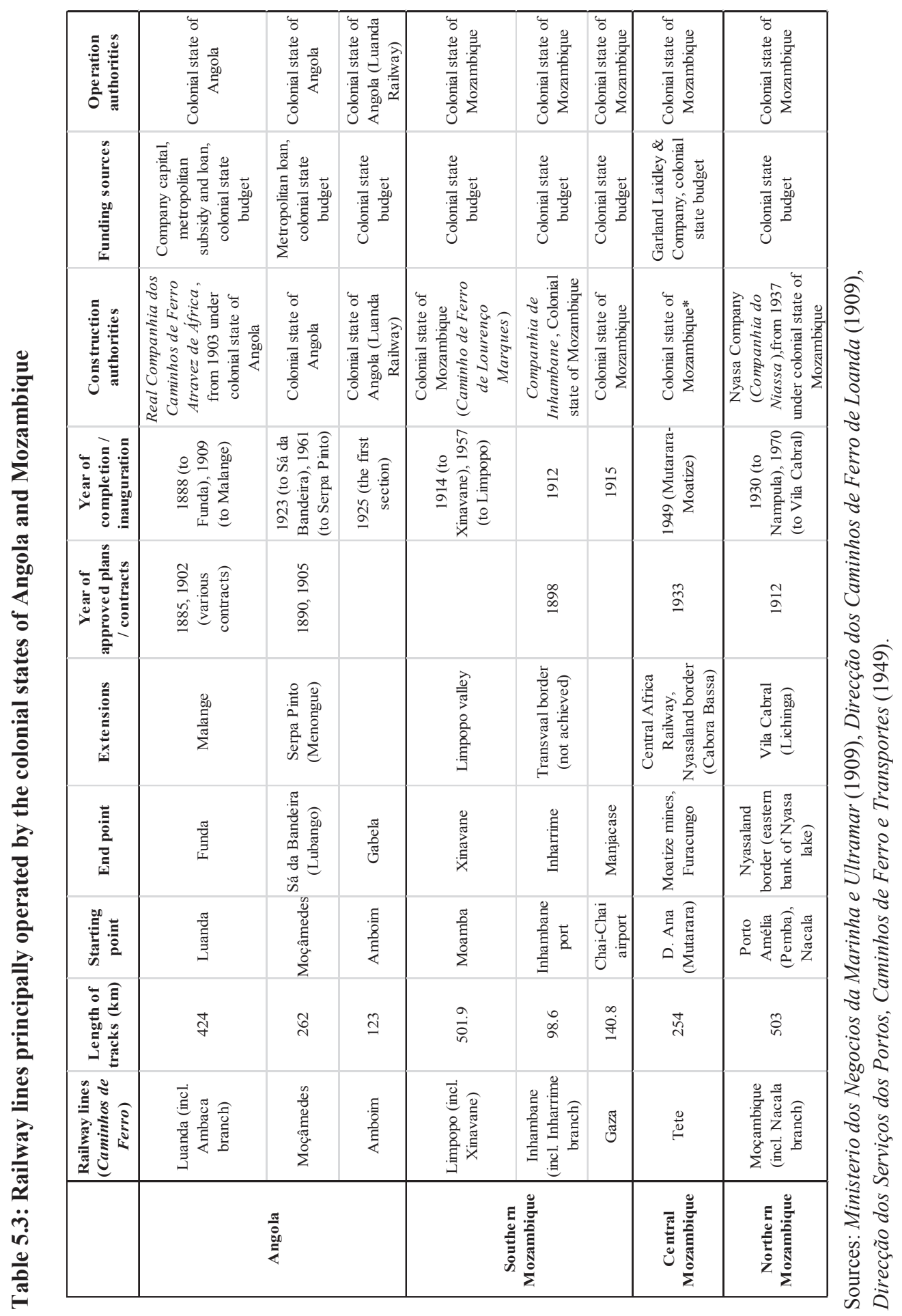


Plans to build the Tete line were under consideration for no less than 18 years (ibid, p.237). ${ }^{105}$ Ultimately, the government assigned the project to the Direcção dos Serviços dos Portos, Caminhos de Ferro e Transportes, which would link the Tete railway to the Central African Railway. In 1932 the railway was characterized by the Conselho Superior de Obras Públicas e Minas as "the most urgent project in Mozambique" (ibid, p.239). In 1933 the Ministry approved the plan and initiated construction works (Lima 1971, Vol.II p.234). The line would reach the Moatize coal mines and the plateau of Tete to facilitate the exploration of mineral resources and link up to the Trans-Zambezian (Vasconselos 1948, pp.17-18). Tete had access to a road network, but the railway was indispensable for the industrialization of the region. The iron industry of Tete could compete with the Transvaal mines as it benefitted from the small distances between the coal and iron deposits, the low price of primary materials and cheap supplies of indigenous labour (Lima 1971, Vol.II, p.238). Tete was closer to the sea and was also suitable for cash-crop cultivation (cotton, rubber, coffee).

The first stretch was completed in 1934 and opened the opportunity for new European settlements. New funds to continue construction were made available in 1936 (ibid, p.239). The Ministry of Colonies stressed the need to build the rest of the line under state control and not via concession. Dr. F.J. Vieira Machado referred to the example of Beira and other territories being economically depended on railways constructed with English capital to argue that "in modern times economic dependency easily transforms into political dependency" (ibid, p.241). In 1938 the works begun (ibid, p.247). The completion of the construction was delayed, due to the war and disease outbreaks. The line from Mutarara to Moatize was inaugurated in 1949 (ibid, p.248). Eventually, the Tete plateau proved unsuitable for European colonization, due to its harsh tropical climate and the potential of the mining industry remained to a large extent untapped. The line faced huge deficits in the 1940s, which had to be covered by the colonial state budget (Vasconselos 1948, p.19).

Finally, the line of the Moçambique district in the north also had a long and complex development history. Initially, the construction of a railway starting from Porto Amélia to lake

\footnotetext{
${ }^{105}$ By the end of the so-called "Niassa Campaign" against the Germans in 1918, the Portuguese attempted to intensify the economic occupation of the central zone of Mozambique - particularly the Tete district with coal and copper reserves - and give a more prominent role to the port of Quelimane. The negotiations between the Governor of Mozambique, Maxano de Amorim, and Pauling \& Co on the construction of a railway failed and the construction could not proceed without the issuing of a longterm loan of 35 years. The Empresa Mineira do Moatize refused to finance the exploration and the construction, while the Canadian Garland Laidley \& Company offered to fund 7 years of construction.
} 
Niassa was included in the concession agreement of the Niassa Company with Portugal, but indigenous resistance stalled the Company's plan (Lima 1971, Vol.II. p.264). In 1912 a metropolitan decree allocated 100,000 Escudos to its construction, but without additional loans the financing remained problematic (ibid, p.269). In 1924 the plan was changed to include the exploration of a line between Lumbo port and the Moçambique island to the west. These territories were under company administration until 1929, when they passed under the control of the state (Vasconselos 1948, p.15). The need to link the island of Moçambique with the continent via a bridge was stressed by Oliveira Martins, the head of the municipality. His idea was realized after the initiative of M.M. Sarmento Rodrigues, the governor of the colony, who granted a credit of 20 million US dollars for the beginning of the works (Lima 1971, Vol.II. p.273), while the remainder was financed by the colonial budget, apart from an additional agreement of the port town Luombo with a foreign company. In 1930 the line reached Nampula (ibid, p.274).

In 1937 the Direcção dos Serviços dos Portos, Caminhos de Ferro e Transporte was put in charge of linking Moçambique to the port of Nacala and the Tete railway (ibid, p.276). In a report in 1938 the engineer Pinto Teixeira summed up the motives for this line: it gave access to recently discovered coal fields, it would keep cattle safe from tse-tse and it would open up the higher altitudes suitable for agricultural settlements (Lima 1971, Vol.II. pp.289-290). These prospects were never realized, however, as settlers stayed away. Bad climatic conditions, the war and continuous attacks by indigenous people who were perceived as organizações terroristas (ibid, p.291) made the northern region unattractive to European settlers. In 1942 the line was inaugurated and by 1945 it ran a considerable deficit (Vasconselos 1948, p.16). In 1950 the idea of accessing lake Niassa was revived again (Lima 1971, Vol.II. p.277) and by 1969 the extension up to Vila Cabral (today’s Lichinga) was finally completed (ibid, pp.284285).

\section{General patterns}

This section presented, on the one hand, the railways that were principally controlled by concession companies and private investors; and on the other hand, the railways that were controlled by the colonial states of Mozambique and Angola. In reality these two categories were not necessarily exclusive, because the construction and operation of most railways were financed by various sources: metropolitan subsidies and loans, colonial state and district 
budgets as well as private capital. However, Portugal was an economically weak metropolitan power with limited access to international credit markets, therefore attempted to outsource as far as possible the cost of railway construction in its colonies. Some railway projects easily attracted private capital (i.e. Benguela Railway), but others were taken over by the colonial states at an early stage (i.e. Luanda Railway). Companies targeted the immediate profit from mineral extraction and transit trade, while the colonial states had a dual agenda of effective occupation and long-term development. Colonial officials were preoccupied with the creation of new settler communities and the expansion of existing ones. The foundation of Direcção dos Serviços de Portos, Caminhos de Ferro e Transportes by Salazar's New State in 1931 was a rupture that signified the shift of power from concession companies to the colonial states, which eventually took over the management and financing of almost all railways in Mozambique and Angola.

Specifically, the following conclusions can be drawn from the above historical narrative as well as tables 5.2 and 5.3: First, private capital was clearly attracted by lines with greater economic potential. The lines that were considered "productive" were those linking major port cities to mining areas or large plantations in the hinterland. In contrast, the colonial governments focussed on lines with higher risk or lower perceived economic potential and also took over privately constructed lines which turned out to be loss-making or operated inefficiently (for instance, Tete and Quelimane Railways). Second, where there was interest of a foreign country involved, it was much easier to realize a railway construction plan (for example, in the cases of Lourenço Marques and Beira Railway). Stronger states and economies, such as South Africa and the Belgian Congo played a considerable role in the extension of the railway network in Southern and Central Africa.

Third, the more successful concession companies (i.e. Company of Mozambique in the central region of Beira compared to Niassa Company in the northern zone of Mozambique) were more effective in infrastructural expansion. Moreover, the lines with higher economic potential (aiming at mineral exploitation) were constructed faster, certainly in a shorter number of years than the lines that served political purposes such as the development of colonial settlements or the improvement of natives' living conditions. The most prominent example is the Benguela Railway, which reached the end point within Angola's borders (Huambo) in only nine years, despite its considerable length (it still is the longest line in Africa). It remained a privately controlled line throughout the colonial era and even after the independence. A typical counter-example was the state-run Moçambique Railway, which required 18 years to reach 
Nyasaland border and another 40 years to reach the end point of Vila Cabral, although its total length was just half of the Benguela line.

Last, a systematic comparison between the Portuguese states of Mozambique and Angola with respect to infrastructural investments adds to what chapters 2, 3 and 4 have already revealed: Both Portuguese states invested in transportation for various economic and political purposes, determined by external and internal factors. However, they slightly differed: Mozambique, as a more diversified and less integrated colony, obtained a more complex railway network serving mineral and agricultural clusters as well as facilitating native labour migration and colonial settlements. The colonial government of Angola, on the other hand, ran a highly militarized state (to deal with strong native resistance) and viewed railways principally as a vehicle for occupation, facilitating the transformation of the territory into a "settler colony", while spreading European civilization.

\subsection{Railways, urbanization and colonial settlement}

Privately constructed railways performed better than state-run railways, in terms of traffic and consequent revenue. In addition, urban settler communities (e.g. Luanda, Lourenço Marques) attracted more infrastructural investments, which created in part a self-sustaining dynamic in future settlement patterns.

As figures 5.2 and 5.3 display, in Mozambique the railway and road network of Lourenço Marques were the busiest ones in terms of passengers, commodities transported and car trucking (the latter from 1945 onwards). The Trans-Zambezian line also emerged in the colonial records from 1930 and demonstrated noteworthy traffic. Last, the railway line and road crossing the Beira district became of crucial importance from the 1950s onwards. In other words, the privately constructed railways of the colony demonstrated the highest traffic in terms of both passengers and commodities. The highest traffic was observed in the most urbanized districts, trade centres and port cities. On the contrary, traffic was insignificant in the rural districts of the centre and the north (Inhambane, Tete, Quelimane and Moçambique). This persisted after 1940, when the forced cotton schemes were introduced by the colonial state. 
Figure 5.2: Shares of railway and road passengers per district in Mozambique, 19261970

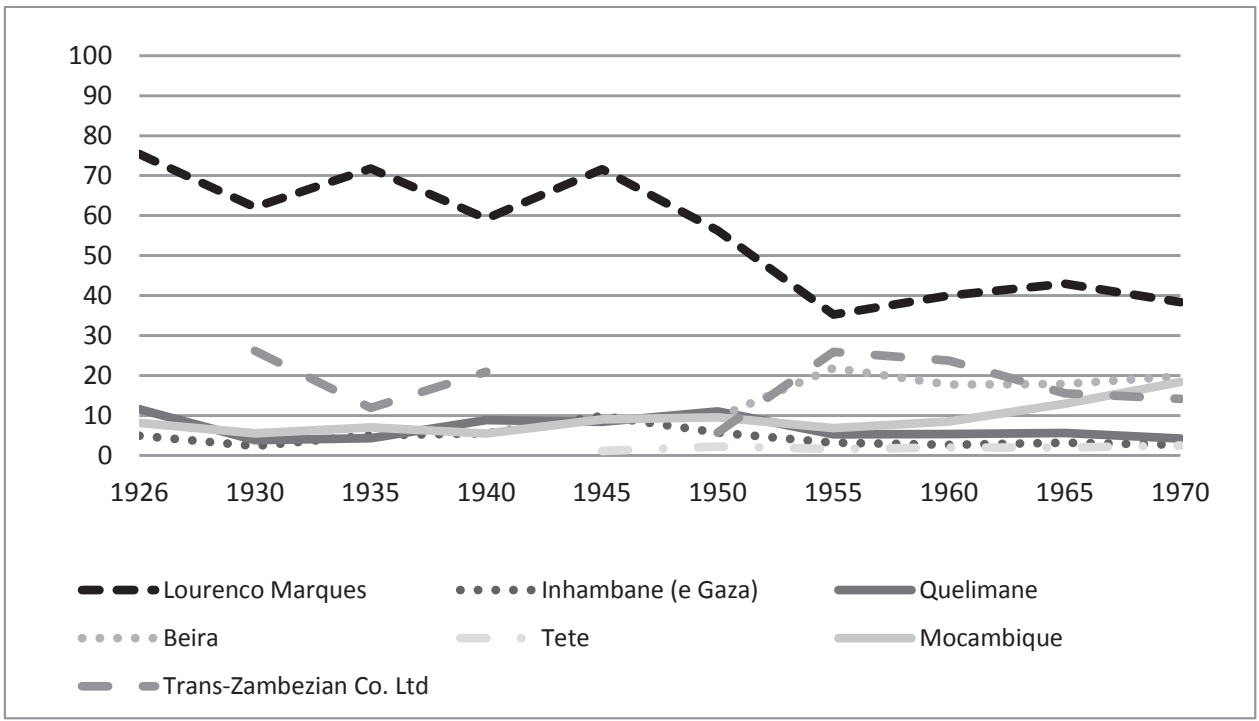

Source: Colonia de Moçambique, Repartição Central de Estatística Geral. Anuário Estatistico (Statistical Yearbook), various issues between 1926-1970.

Figure 5.3: Shares of commodities transported per district in Mozambique, 1926-1970

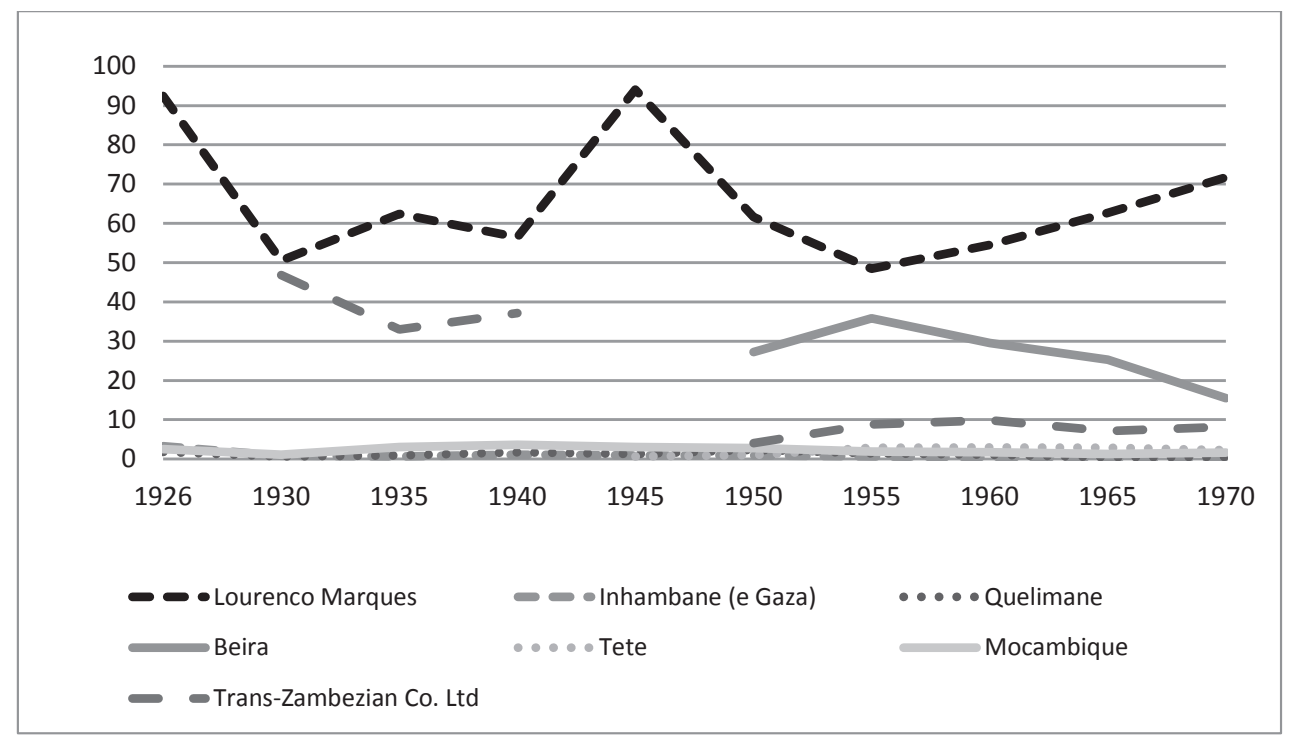

Source: Colonia de Moçambique, Repartição Central de Estatística Geral. Anuário Estatistico (Statistical Yearbook), various issues between 1926-1970. 
The private companies as well as the state had limited interest in the construction of railways and roads in the rural areas, despite the high population density in some of these areas. As Alexopoulou and Juif show, in 1939-1940, in the north 90\% of the economically active population worked in agriculture, while this share was only $54 \%$ in the south $(2017$, p.242). The lack of infrastructural investment in the north of Mozambique, notably the most densely populated region of Mozambique, undoubtedly contributed to its impoverishment and isolation. Only in the 1960s an efficient road was built to connect the north to the south. "Road building remained the responsibility of the local authorities and no network was created to link different regions of the colony until the last decade of colonial rule" (Newitt and Tornimbeni 2008, p.712).

In contrast, the two port cities of southern and central Mozambique, Lourenço Marques and Beira, recorded ten times as much traffic in passengers and commodities as the other districts in the north and the centre. Southern Mozambique developed a settler farm economy and served as a labour reserve for other areas in Southern Africa. The earliest railways facilitated the transport of white passengers, commodities and African migrant workers to the South African mining regions and were designed and subsidized by the South African government (or predecessors). The transport of white passengers and commodities were prioritized over transport of migrant workers to the mines. The latter were only allowed to use the line fifteen years after the opening in $1890 .{ }^{106}$ By 1910, special "native labour trains" were introduced on the eastern Transvaal route (Pirie 1993, p.716-721). ${ }^{107}$ The 1928 Convention between the Portuguese government and the Union of South Africa reveals the importance of the railways for transit trade and the supply of migrant workers from Mozambique to the mines in Transvaal (Boletim Official 1928, pp. 336-337). ${ }^{108}$

\footnotetext{
${ }^{106}$ Since the late 19th century the majority of migrant workers in Transvaal came from Mozambique by walking across the border at Ressano Garcia. Pirie discusses the conflicts between mining and railway companies and other constraints that hindered railways from becoming the official carriers of migrant labour (Pirie 1993, pp.714-715).

107 The migration was concentrated at Lourenço Marques and was organized by Witwatersrand Native Labour Association (WNLA). There were different fare regimes and discounts for large groups and lengthy journeys (Pirie 1993, pp.723-724), but payments made to the railways by the recruiters were covered by wage deductions (ibid, p.725) and consequently were paid by the African workers themselves.

${ }^{108}$ This bi-lateral agreement stipulated the terms for the use and supply of indigenous labour conditions, the use of the port and railways and the terms of commercial exchange (Freire d' Andrade 1928). The convention was severely criticized by local and foreign media. The Guardian, for instance, condemned indigenous labour recruitment policies and health conditions at the Rand mines, while the Star
} 
Figure 5.4 demonstrates that in 1930 the vast majority of European settlers in the colony lived principally in the two major urban hubs, while the majority of Africans inhabited the rural districts of the north and centre, such as Quelimane and Moçambique/Nampula. In 1960 the proportion of whites in the northern rural zone was virtually zero, while in the southern zone, including Lourenço Marques, it was at least 4\% (ibid). The early presence of railways only further enhanced this settlement pattern. This is in line with Herbst's argument that imperial powers disproportionally built railway lines and roads in the core areas, concentrated around the main cities (2000, p.167).

\section{Figure 5.4: Distribution of indigenous and non-indigenous population over districts (as share of total indigenous/non-indigenous) in Mozambique, 1930}

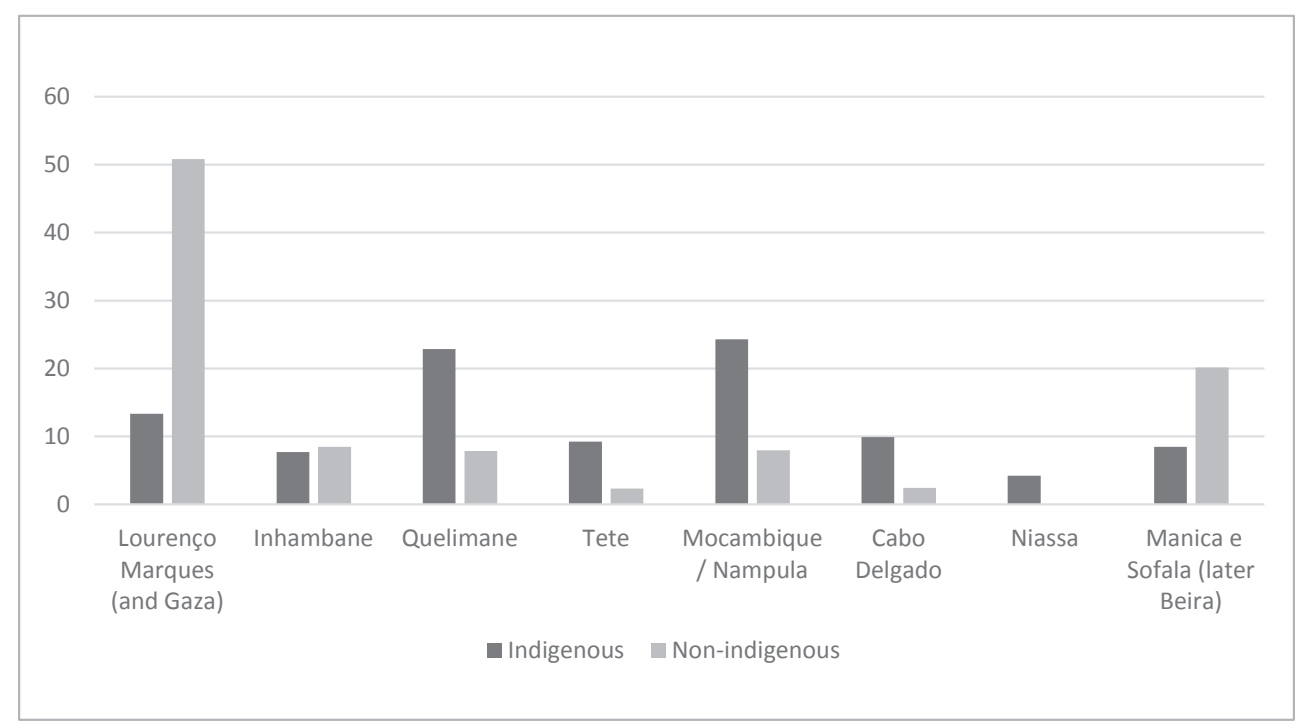

Source: Colonia de Moçambique, Repartição Central de Estatística Geral. Anuário Estatistico (Statistical Yearbook), 1928 and 1930 censuses.

Figures 5.5 and 5.6 reveal the critical importance of the privately constructed Benguela railway in Angola, in terms of its share in total passenger and commodity transport. Nevertheless, only in the post-war period, when the transport of minerals increased

(published in Johannesburg) commented on the restrictions and heavy fees that mining companies had to bear as well as the unfavourable terms for South African railways and trade (The Star 13.7.1933). 
significantly, the Benguela Company made a profit. The port of Lobito, the starting point of the Benguela Railway, also grew in importance. The privately constructed Luanda Railway, which soon passed under state control, ranked second. Luanda was already the most vital city of Angola during the construction phase. Indeed, Angola's urban network also "remained highly dependent on road and rail connections to the main coastal ports" and present-day's urbanization derives primarily from colonial settlement patterns (Udelsmann Rodrigues and Tavares 2012, p.689).

Figure 5.5: Shares of railway and road passengers per district in Angola, 1932-1970

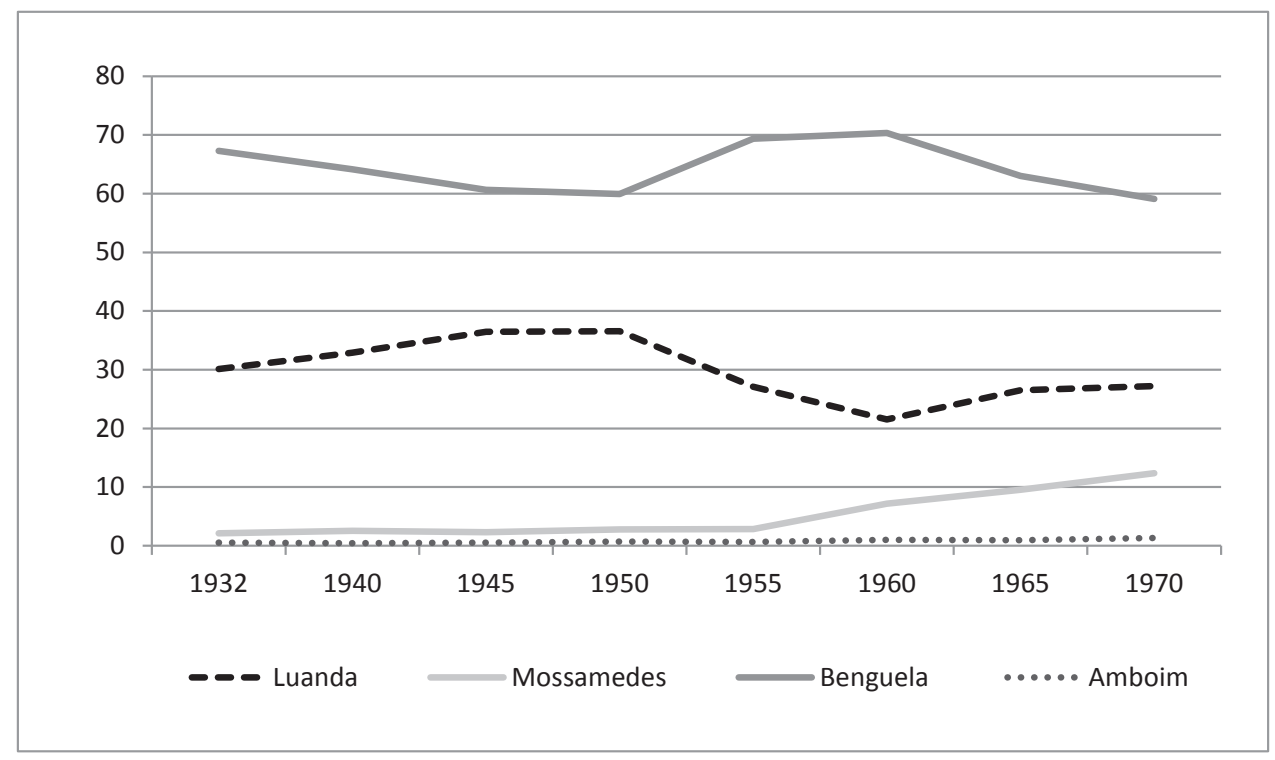

Source: Colonia de Angola, Repartição Central de Estatística Geral. Anuário Estatístico (Statistical Yearbook), various issues between 1932-1970. 
Figure 5.6: Shares of commodities transported per district in Angola, 1932-1970

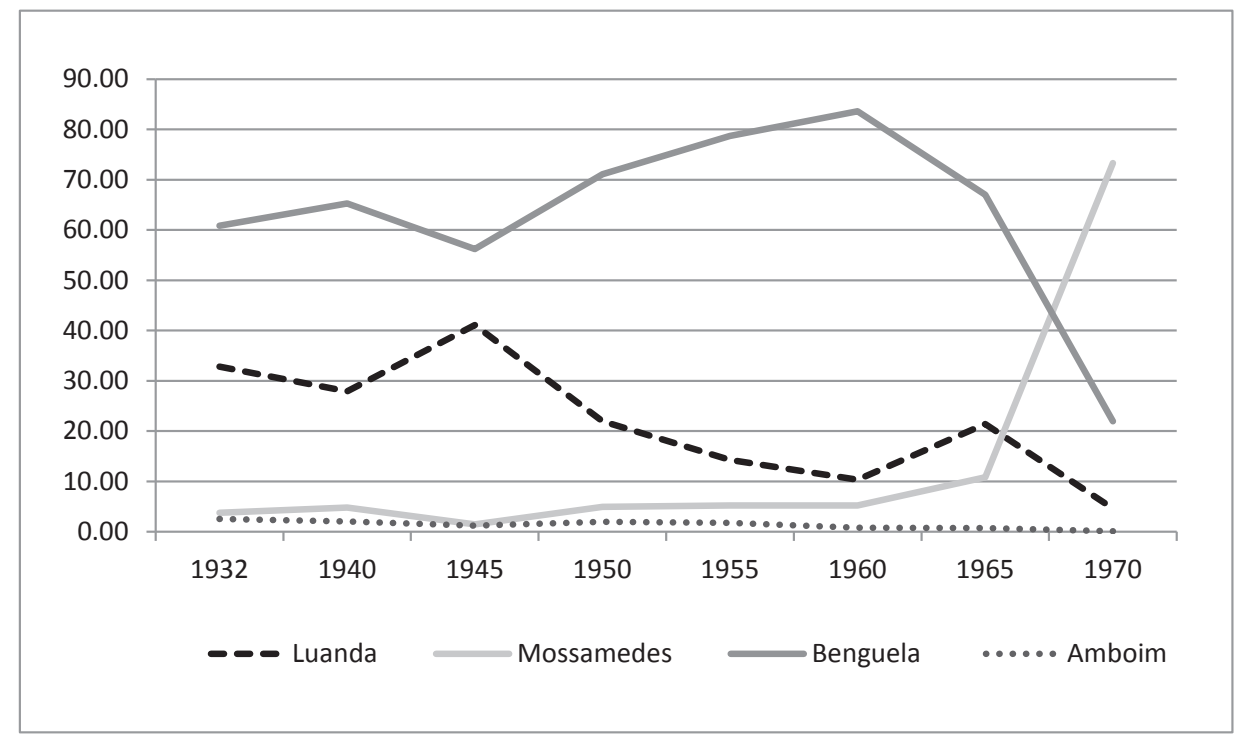

Source: Colonia de Angola, Repartição Central de Estatística Geral (1933-1973). Anuário Estatístico (Statistical Yearbook), various issues between 1932-1970.

In any case, figure 5.7 shows that in 1933 the vast majority of the white settler population $^{109}$ in Angola lived in the most urbanized and commercialized centres such as Luanda, Huila and Mossamedes. Luanda was founded in 1575 by the Portuguese and has been the administrative centre of Angola since 1627 (except for the years 1640-48). From the mid16 th to mid-19th century it was the centre of the trans-Atlantic slave trade. From the 1920s to the 1960s, abundant natural resources and infrastructure development led to the arrival of an increasing number of Portuguese settlers from the metropole. Similarly, Benguela and Mossamedes were also crucial port cities and the three of them were the starting points of the principal railway lines. Moreover, Huambo and Huila provinces, where a considerable share of white people lived and mingled with the black population, benefited from the opening of railway stations.

${ }^{109}$ White population is classified as civilized population (população civilizada) in the statistical yearbooks of Angola, in contrast with the African population which is classified as non-civilized (não civilizada). 
Figure 5.7: Distribution of indigenous and non-indigenous population over districts (as share of total indigenous/non-indigenous) in Angola, 1933

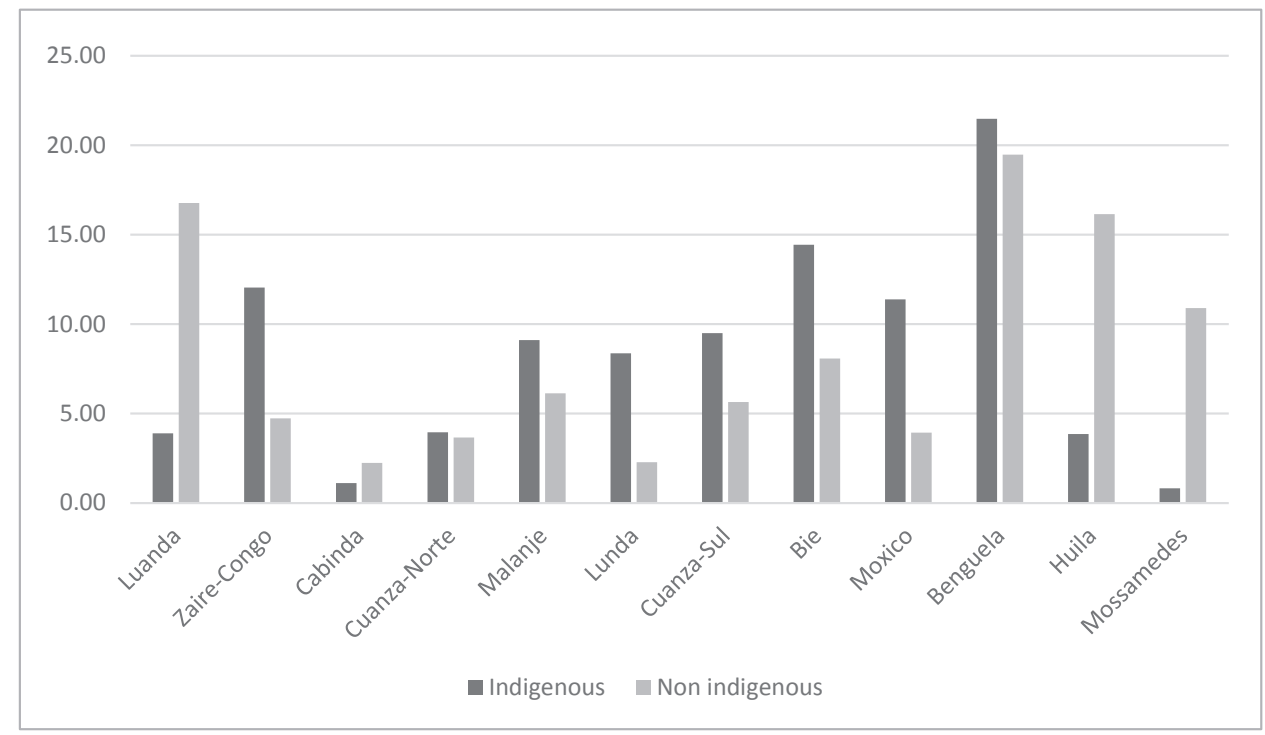

Source: Colonia de Angola, Repartição Central de Estatística Geral. Anuário Estatístico (Statistical Yearbook), 1930 census.

Huambo became one of the main economic centres of Portuguese Angola, serving as transhipment station for agricultural products from the province to the Benguela railway. The city developed food processing units as well as research and training institutes. In 1928 Huambo was renamed Nova Lisboa. The city gained prominence in the 1960s and by the 1970s. Another example of railway-induced urbanization is Lubango, whose official name was Sá da Bandeira until 1975. A thousand Portuguese settlers, especially from Madeira island, had migrated to Lubango in the early 1880s (Bastos 2008). Sá da Bandeira became an important station at the Mossamedes line in the 1920s and also experienced a growth impulse during the 1960s.

Areas inhabited almost exclusively by Africans such as Congo and Moxico districts did not have access to the railways. Moxico was a distant eastern hinterland province which challenged Portuguese domination until the late colonial era. In the early 1900s "crossing the hinterland from Moxico to Benguela by foot was [... the only way to reach the coast from the Eastern Angolan border [...]; no roads or bridges were constructed; and the railway network 
from Luanda only reached the Eastern province in 1913, and the border in 1929" (Roque 2003, p.105). The district of Congo in northern Angola was known for the revolts and mass migrations of Africans trying to escape enslavement in the $18^{\text {th }}$ and $19^{\text {th }}$ centuries. ${ }^{110}$ During the post- WWII coffee boom, the Congo district urgently needed a stable labour force (Keese 2012) and relied extensively on coerced labour.

Unlike the other areas with access to railroads, Bie and Malanje were inhabited by a large share of the total African population. The construction of Luanda Railway in the early 20th century contributed substantially to the expansion of Malanje city. It attracted Portuguese settlers who made a living by trading agricultural products from the coffee and sisal plantations of the surrounding areas (Udelsmann Rodrigues and Tavares 2012, p.691). ${ }^{111}$

Finally, Lunda Sul and Lunda Norte was a remote diamond zone, sparsely populated and far away from the coast and overland transportation routes. The growth of colonial Lunda cities was largely planned and administered by the mining company Diamang, in cooperation with the colonial authorities (Udelsmann Rodrigues and Tavares 2012, p.688). Diamang (Companhia de Diamantes de Angola) was granted a concession for diamond mining in 1917, which it maintained until independence. ${ }^{112}$ Diamang fostered urbanization through enclosed residential compounds for mine workers (Cleveland 2008). By the 1970s, only the capital of Lunda Sul, Saurimo, which was strategically located on the main national road axis and was connected to Malanje and the Benguela railway, grew considerably in population (Udelsmann Rodrigues and Tavares 2012, p.691).

The settler geography of the two colonies in 1930 shows that the white population in Angola was more evenly distributed across districts than in Mozambique. This implies less spatial or regional inequality and better integration of the two -broadly defined- population groups (European settlers and native Africans). However, it does not necessarily imply that there was less socio-economic or racial inequality. The racial division of the population into a superior and an inferior class was in force up to 1961. The more even distribution of the white population in Angola might have been actually the result of more "aggressive" metropolitan settler policies, explained by Angola's large size (two times bigger than Mozambique) and

\footnotetext{
${ }^{110}$ In the past, the area was part of the African kingdom of Kongo, along with the district of Cambinda. 111 When the sisal's prices started to drop, forced cotton schemes were applied in Malanje by the concession company Cotonang.

${ }^{112}$ Diamang was a public Portuguese firm with capital provided by the South African company DeBeers and other European companies. It had exclusive mining and labour supply rights and became the colony's largest commercial operator as well as its leading revenue generator. Many African labourers were forcibly recruited to work on the mines (Keese 2013).
} 
strong natives' resistance against the colonial rule. The Portuguese community had a longlasting presence in Angola and settled in areas previously inhabited by Africans, so the two population groups mingled. ${ }^{113}$ The demographic colonization of Angola was slow but steady (Pimenta 2016, p.277) and the Angolan white community became the second largest in Africa, while it developed a national identity distinguished from the Portuguese citizenship (ibid, p.278). ${ }^{114}$

\section{5. 'Development' through coercion}

From an early stage, the colonial governments of Angola and Mozambique controlled most of the railways and financed the ones on deficit. This section seeks to explain how both states managed to expand their railway networks, despite the clear economic weakness of the metropole, the limited access to international credit markets and the modest interest of private investors to fund railways. The overall explanation has three major components. First, part of the network was meant to unlock mining areas in neighbour colonies, and these projects received a substantial push from foreign, and in particular, British investors. But the Lourenço Marques and Benguela lines are the exceptions, albeit major ones. The two other explanations are the heavy use of forced labour for public works and the extractive nature of indigenous taxation. This section focusses on these two forms of extraction.

\section{Coercive labour in the construction of railways}

The use of forced labour was extensive in many African regions under Portuguese, Belgian and French rule and contributed significantly to the construction of railways and roads all over

\footnotetext{
113 As chapter 2 describes, prazeros (Portuguese merchants and land-owners) in central Mozambique also mingled with native Africans during the 17th and 18th centuries. However, they were less in number than Angola-born white settlers and concentrated in one single region (Zambezia). Plus, prazo families came into conflict with the Portuguese Crown during the Scramble for Africa and were defeated, so they lost their power in the early years of the official colonization of Mozambique.

${ }^{114}$ It is known that in the 1940s Angolan settlers started to support the independence of Angola from Portugal (Pimenta 2016, p.279). Nevertheless, they dreamt of an independent Angola governed mainly by the Angola-born white settlers. In 1951 Salazar officially changed the status of Angola from a colony to an Overseas Province and in 1955 the metropole allowed the formation of a Legislative Council consisted of white settlers and assimilated Africans (ibid).
} 
colonial Africa. ${ }^{115}$ Abundant land and low population densities made voluntary wage labour scarce, especially outside urban centres, and slavery was abolished before the railway boom in late $19^{\text {th }}$ and early $20^{\text {th }}$ century Africa. The colonial governments could increase labour either by offering incentives such as competitive wages or by obliging Africans to work for certain periods by coercion. In the Portuguese colonies, the second solution was the standard. Both colonial states used indigenous authorities (cipaios e régulos) to force peasants to abandon their land and work for the state or for private concession companies (Chilundo 2001, p.137). Keese has elaborated on the concept of taxa braçal, which signifies the enforcement of labour obligations as a form of direct taxation in Portuguese Africa (2013, p.242).

Colonial authorities used the indigenous institution of communal labour (for tribal purposes) to create new labour reserves for public works at the communal and state level. The main idea was that indigenous people had a moral obligation to work and pay taxes to the colonial state. Efforts of the International Labour Organisation starting from the 1920s to ensure certain labour standards had some effect, but Portugal refused to ratify the 1930 ILO Forced Labour Convention (No 29) until 1956.

In early colonial Angola, the "native problem" was widely discussed in administrative reports and newspapers, where settlers complained about the insufficient control of the hinterland and the lack of manpower to boost the plantation economy (Ball 2015, p.4). In this context, the colonial authorities formalized forced labour under the 1899 labour code (Regulamento do Trabalho Indigena) which was reinforced by the 1911 and 1914 codes. Africans who failed to engage in wage employment and fulfil their annual tax obligations, would be enlisted by colonial officials for compulsory labour (compelido). In parallel, local chiefs were responsible for providing the government with contract labourers (contratados) for public works. According to the 1914 regulation on punitive labour (correcional), the latter could work for private enterprises only when the state did not need the workers.

115 The French authorities used military recruitment to obtain manpower for public works. Van Waijenburg (2018) has estimated the extent to which coercive labour saved expenditure for the French rule in West Africa. In Belgian Congo the natives were obliged to offer forty hours of labour per month in the form of rubber gathering for the state or private companies (ibid, p.71). France ratified the 1930 ILO Forced Labour Convention in 1937, while Belgium in 1944 (source: http://www.ilo.ch/dyn/normlex/en/f?p=NORMLEXPUB:11300:0::NO:11300:P11300_INSTRUMEN T ID:312174:NO). British colonialists also used forced labour, but they did not organize it as systematically as the other imperial powers. The British actually owed their benign reputation to the early adoption of the ILO regulations, by enforcing the Forced Labour Convention in 1931. 
In the 1920s the colonial authorities enhanced their control over the hinterlands where many subjects kept resisting to migrate and work for low remuneration. After the 1926 coup in Portugal and the establishment of Salazar's New State (Estado Novo) in 1933, a colour bar system, the Indigenato, was introduced (O'Laughlin 2000). According to the Indigenato, white settlers and assimilated Africans (only 1\% of the native population by the 1950s) were officially entitled as 'citizens', while the vast majority were subject to traditional authorities, who were responsible for labour recruitment and tax collection. A decree in 1926 made remuneration obligatory for compulsory labour (1928 code). A circular in 1942 assigned all men 18-55 years old to work for the state at least for 6 months. In practice, the contracts were often prolonged, depending on the needs of the project. ${ }^{116}$ Men and women were sent by local administrators to construct and maintain roads and railways. Forced labour was banned only by the end of Indigenato in 1958.

Official reports and newspapers reveal how crucial the access to indigenous labour was for the completion of the railway lines in Mozambique and Angola. For instance, the Limpopo Railway had required the hard work efforts of an estimated 500 Europeans and 5,000 Africans (O seculo, 1959 January 7). According to Lima, 1,350 African workers should "be honoured" for the construction of the Moçambique line in the north (1971 Vol.II., p.275). Esteves (2000) mentions the harsh working conditions and high mortality rates during the construction of Benguela Railway in Angola. Silva stresses that the local manpower was not sufficient and workers, experienced in the building of railways, were imported from the surrounding colonies: in the case of Benguela Railway, 7,000 Africans were brought in from Nigeria and Senegal and 2,000 Indians from South Africa (2008, p.3).

Colonial state budgets and accounts unfortunately do not provide us with information on the total numbers of forced and voluntary workers being employed at the national or local level. Although there are no consistent statistics available to construct annual time series, qualitative sources suggest that forced labour was as sizable as waged labour. For instance, Ball estimates that in Cassequel sugar plantations in Angola only half of the workforce consisted of voluntários and the company relied extensively on forcibly recruited workers supplied by the state $(2015$, p.24). When forced workers were asked to choose where to work, they preferred

\footnotetext{
${ }^{116}$ Van Waijenburg distinguishes between corvée and conscript labour in French Africa: While corvée was restricted to relatively short periods of time, "conscript labour was introduced to secure workers for more extended periods of time. Most large public works projects, such as the construction of railways, needed a steady supply of cheap year-round workers" (2018, p.48).
} 
plantations over railways despite the lower wages there, since working conditions in railway construction were horrible (Chilundo 2001, p.148).

Van Waijenburg asks how much colonial states saved from forced labour practices in French Africa (2018, p.52). How much would the states spend if they had to hire all these corvée workers for a standard cash wage? She makes calculations based on prestatións, the annual amounts spent by African men to buy off their forced labour obligations. In the case of Portuguese Africa, the data do not allow us to make such estimates, but we do have some revealing benchmark data to illustrate the magnitude and financial importance of forced labour in the construction of railways.

According to Mozambique's governor, 8,115 workers were recruited for the construction of the Moçambique railway between June 1913 and March 1914: 3,817 were voluntários (47\%), 3,487 contratados (43\%), and 819 compelidos $(10 \%)$ for not paying the hut tax (Chilundo 2001, p.113). ${ }^{117}$ Hence, in 1913-14 53\% of the workers on the Moçambique railway consisted of contract and compulsory workers (perhaps including convicts), who were all forcibly recruited. Convict workers received half or $1 / 3$ of the salary attributed to voluntary workers at the same place (ibid, p.142). Judging from available lists of occupations, voluntary workers often had certain skills that made them more expensive. The alimentation was included in the salary of forced workers and usually consisted of half a kilo rice and sometimes game meat. ${ }^{118}$

Furthermore, we know from annual budgets that in 1913 unskilled African workers such as porters and servants in the ports and railways of southern Mozambique received on average 500 Reis (0.50 Escudos) per day; while the convicts (setenceados) received 100 Reis $(0.10$ Escudos) per day (Orçamento da Receita 1912-1913, pp.56-66). In contrast, European workers gained two or three times more than indigenous workers in similar positions and at least ten times more than the convicts. We also know that, in general, workers in the north received even lower wages, but we assume that the differences between European workers, voluntary African workers, contract workers and convicts are proportionate. Combining both sources of information suggests that the colonial state saved at least $54 \%$ of the "real" labour cost, that is,

\footnotetext{
${ }^{117}$ Railways in Moçambique district in the north differed from other African railways because they relied almost exclusively on domestic labour, with the exception of the Beira-Umtali part, where Indians workers were imported and many died from diseases (Chilundo 2001, p.138).

${ }^{118}$ In the 1940s many workers died of hunger and the inspector suggested the improvement of the alimentation (Chilundo 2001, p.143).
} 
when all indigenous workers would have been paid at market prices according to the minimum standards of European labour in Africa.

\section{Indigenous taxation for the operation of railways}

Chilundo (2001) argues that in the case of railways in the northern district of Moçambique, the colonial state relied on native taxation in order to complete its construction and operate the line. I claim that this was the case for most railways taken over by the colonial state of Mozambique in the early colonial era, whereas Angola relied also on other revenue sources such as metropolitan subsidies and indirect taxes on imports and exports, while the operation of its longest line (Benguela Railway) continued to rely on private capital. As shown in chapter 2 of this thesis, the colonial state of Angola developed collection mechanisms for direct taxation only in the 1920s, whereas for Mozambique direct taxes, including corporate (industrial), property and indigenous (head or poll) taxes were key throughout the colonial era. Alexopoulou and Juif show that the direct tax share in total public revenue in Mozambique is approximately $80 \%$ until 1961, and that indigenous taxes generated the bulk of it (2017, pp.24-25). ${ }^{119}$

Chilundo has argued that tax pressure followed the pace of public works and points at a remarkable rise of hut tax rates over the 1920s, strongly linked to railway construction in northern Mozambique (2001, p.105). In 1921, one year before the works on the railway in Moçambique district restarted, the hut tax increased from 3,5 to 5 Escudos per household and in 1924 it increased to 40 Escudos (!) and a supplementary tax of 5 Escudos was introduced to finance local roads. In 1925 per capita tax reached 62 Escudos, plus 8 Escudos for the additional tax (ibid). In 1926 the governor José Cabral aimed at accelerating the construction process and the hut tax reached 75 Escudos, plus 15 for the additional tax (ibid, p.106). Before 1946 women were not exempted from paying taxes and if they failed to do so, they could be taken along with their husbands to work in road or bridge construction (ibid, p.139).

Although this rise in tax rates was exceptional and partly motivated by increasing inflation, it was imposed all over the colony. Figure 5.8 shows the magnitude of (deflated) native taxation at the country level. European settlers paid property, corporate or professional taxes, but did not pay household or personal taxes, which was the principal source of direct tax

${ }^{119}$ In the early $20^{\text {th }}$ century the hut tax (rated at 2.50 Escudos) was strongly connected with the colonial regime of rural land ownership and "native reserves": this tax was paid by Africans for squatting in the settlers' farms in case they were not sent to native reserves, where the soil was mostly poor (Direito, 2013a). 
revenue. The rise in direct taxation continued even sharper in the 1930s during the governance of Salazar in Portugal. As also shown in chapter 2, this is an indication that fiscal regimes in Portuguese Africa and especially in Mozambique were minimalist only in theory. In practice, the principle of minimalism had to do only with the expenditure side, by keeping welfare investments low. The indigenous people continued to pay high annual taxes. Only after 1961 when the indigenato system had already been abandoned - the indigenous tax was transformed into a personal income tax, without distinguishing between indigenous and non-indigenous people.

\section{Figure 5.8: Real revenue from direct taxes in Mozambique, 1865-1958}

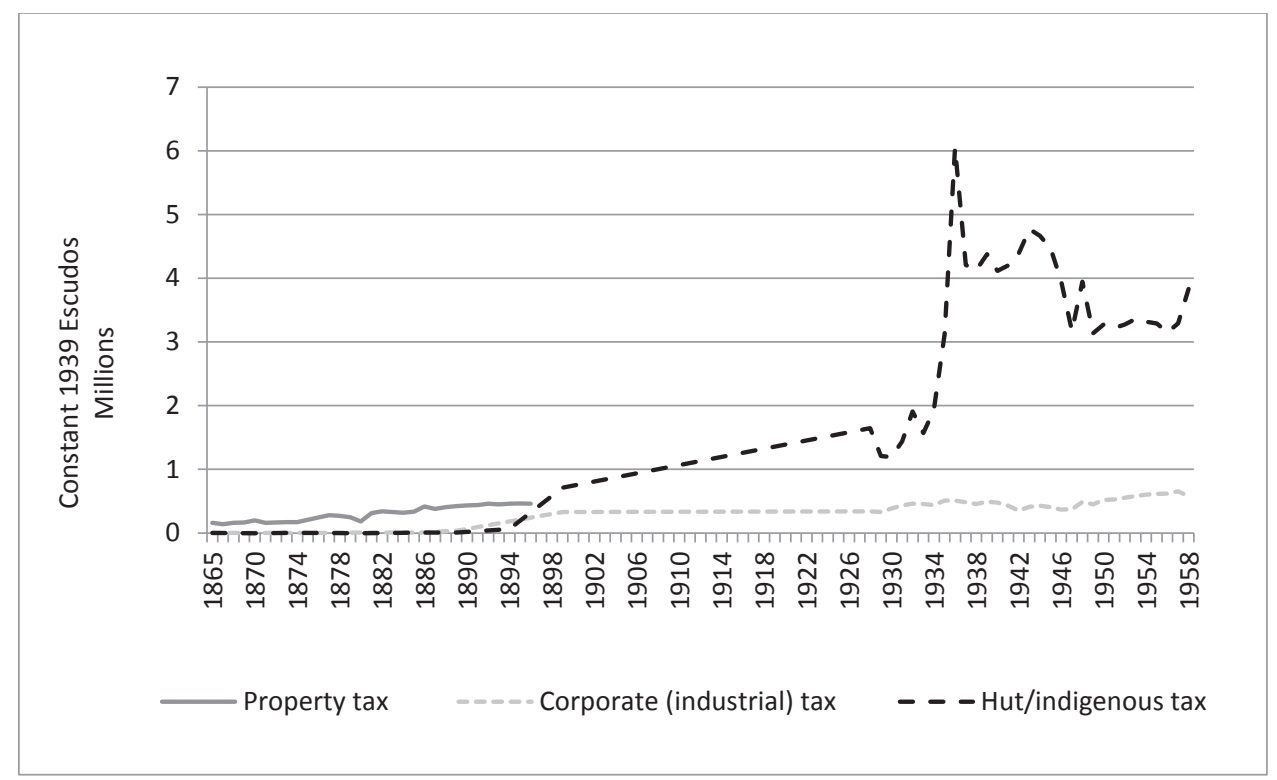

Sources: Governo Geral da Provincia de Moçambique, Boletim Official, various issues between 1850 and 1910; Colonia de Moçam bique,Orçamento Geral, various issues between 1912-1941; Provincia de Moçambique, Contas da Gerência, various issues between 1934-1973; Price deflator: Valério and Tjipilica (2008).

Notes: For the figures referring to the whole colonial era or the early colonial period, I used the consumer price indexes (CPI) constructed by Valério and Tjipilica (2008) especially for Mozambique and Angola, with 1939 and 1914 as base years respectively and extrapolated them based on the CPI constructed by Valério (2001) for Portugal. I deflated all past currencies used by the two colonies for the respective periods: Real (1430-1911), Mozambican Escudo (1914-1980), Angolan Escudo (19141928, 1958-1977) and Angolar (1928-1958). Both the Mozambican and the Angolan Escudo were 
almost equivalent to Portuguese Escudo (1911-1999). In the case of Reis (1 Escudo=1000 Reis) and Angolares (1 Angolar=1,25 Escudos), I first converted them to Escudos before deflating them.

How did the colonial state of Mozambique spend the additional revenue derived from direct taxes? The early colonial budgets of both states were principally characterized by expenses on administration, military and marine forces, while the late budgets were dominated by infrastructure investments. ${ }^{120}$ In 1916 the colonial government decided to allocate $12 \%$ of the revenue from hut taxes to the budget of the Comissao de Melhoramentos, which was created in 1914 to administer all construction works at district level (Chilundo 2001, p.104). In the mid-1930s the colonial state introduced a fund for centrally planned infrastructure development (Fundo de Fomento da Colonia). In 1945 the metropole submitted a Bill on the development and industrialization of the African colonies.

As figure 5.9 shows, in the period 1930-1974, investments in infrastructure including railways, roads, ports and airports, captured an initially small but growing share of the ordinary central budget of Mozambique. The share rose considerably in the 1940s and reached a peak in the late 1950 s around $50-54 \%$. The remaining share of ordinary expenditure was directed to debt service, residual payments from previous fiscal years and miscellaneous charges that usually targeted infrastructure. Extraordinary expenses were covered by metropolitan loans and subsidies, which in times of peace targeted infrastructure as well; while in wartime, they were mainly used for military purposes. Specifically, infrastructure investments dominated the metropolitan transfers of the years 1920-21, 1927-28 and 1946-50 (Ferreira and Pedra 1988, p.91). From 1947 to 1953 Mozambique absorbed more than $50 \%$ of the total metropolitan transfers, which consisted mainly of loans (ibid, p.92).

In the late colonial years the metropolitan government introduced 6-year development plans (planos do fomento) to further boost infrastructure. The first (1953-1958) invested approximately \$55 million in Mozambique and \$100 million in Angola. It almost exclusively targeted ports, roads, railways and telecommunications (Penvenne et al. 2005, p.84). The second 6-year plan invested \$125 million in Mozambique and targeted health, education and agriculture. Both plans aimed at increasing settler migration from Portugal and serving the

\footnotetext{
${ }^{120}$ Unlike with the colonial records on British Africa, in the early colonial era (1850s-1920s) investments in education and health were not even a distinct expenditure category in the aggregated annual statistics of the Portuguese colonies, presented at Boletim Official. However, late colonial accounts (Contas de Gerência) in the period 1930s-1970s provided a more detailed classification, including the distinction of social services.
} 
interests of the existing settler communities in trade, agriculture and irrigation. The threat of the African independence movements in the 1960s motivated settler schemes to strengthen Portuguese presence in the colonies, and infrastructural investments to gain popularity among the African population (Newitt, 1995, pp.461-464). With the exception of the development plans in the 1950s-1960s, which were funded by metropolitan grants, the loans of the earlier period had to be redeemed by the colonial treasuries, and thus by indigenous tax-payers.

Figure 5.9: Shares of public expenditure by category in Mozambique, 1930-1973

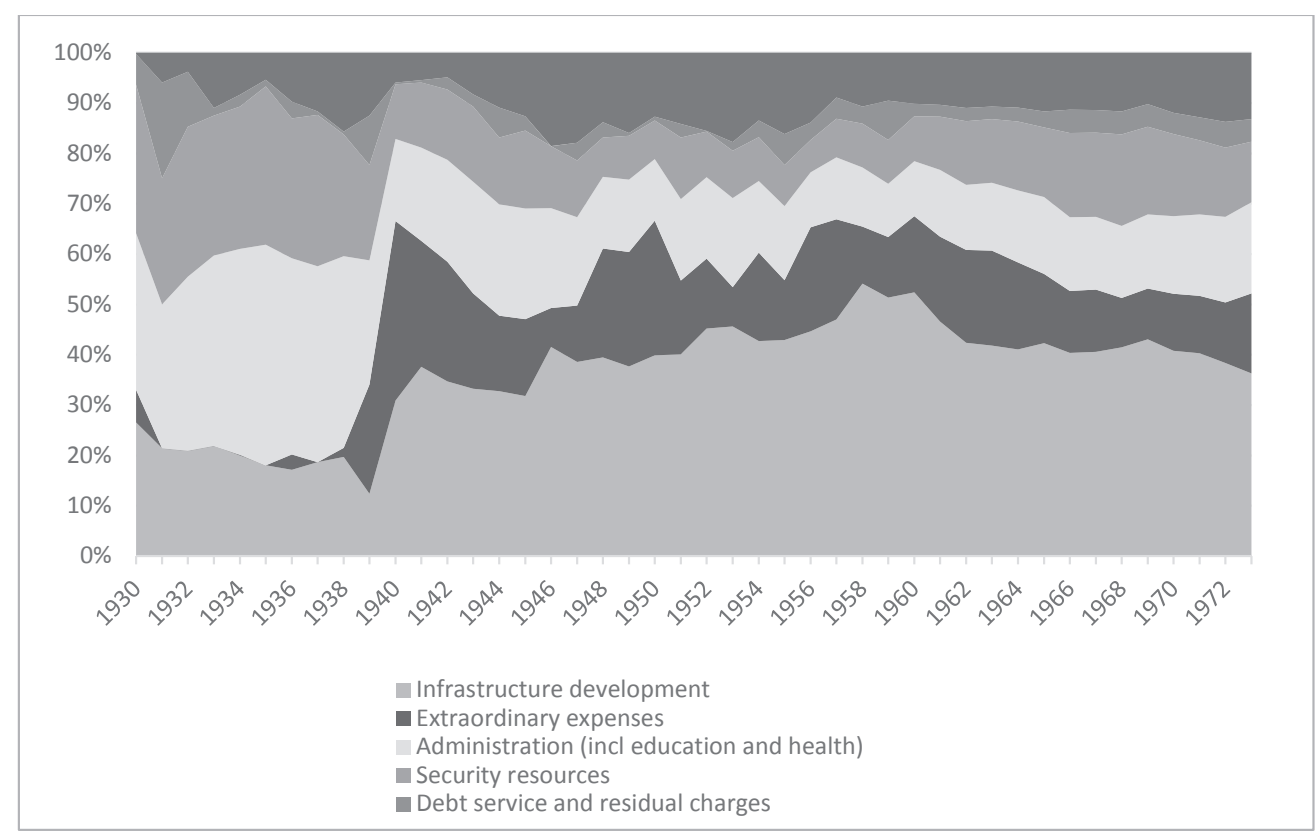

Source: Colonia de Moçambique, Repartição Central de Estatística Geral. Anuário Estatistico, various issues between 1930-1973; Price deflator: Valério and Tjipilica (2008).

As Angola performed much better in export trade, a significant share of its revenue derived from custom duties. Until the 1900s 65-95\% of Angola's revenue derived from indirect taxation (see chapter 2). Only after the 1910s, when the colonial state consolidated its power and established tax collection mechanisms, direct taxes gained in importance. In 1920 the individual tax in Angola was set at 2 Escudos for all "black" and "mixed race" residents. In 1949 the indigenous tax was replaced by a personal annual tax (taxa pessoal anual), which 
remained applicable only to the "black, non-civilized" men, who didn't contribute through other types of taxation (Melo 1953, p.73). Although black people did not have citizenship rights, they were obliged to fund the colonial state that subjugated them and considered them inferior.

Figure 5.10: Real revenue from direct taxes in Angola, 1889-1963

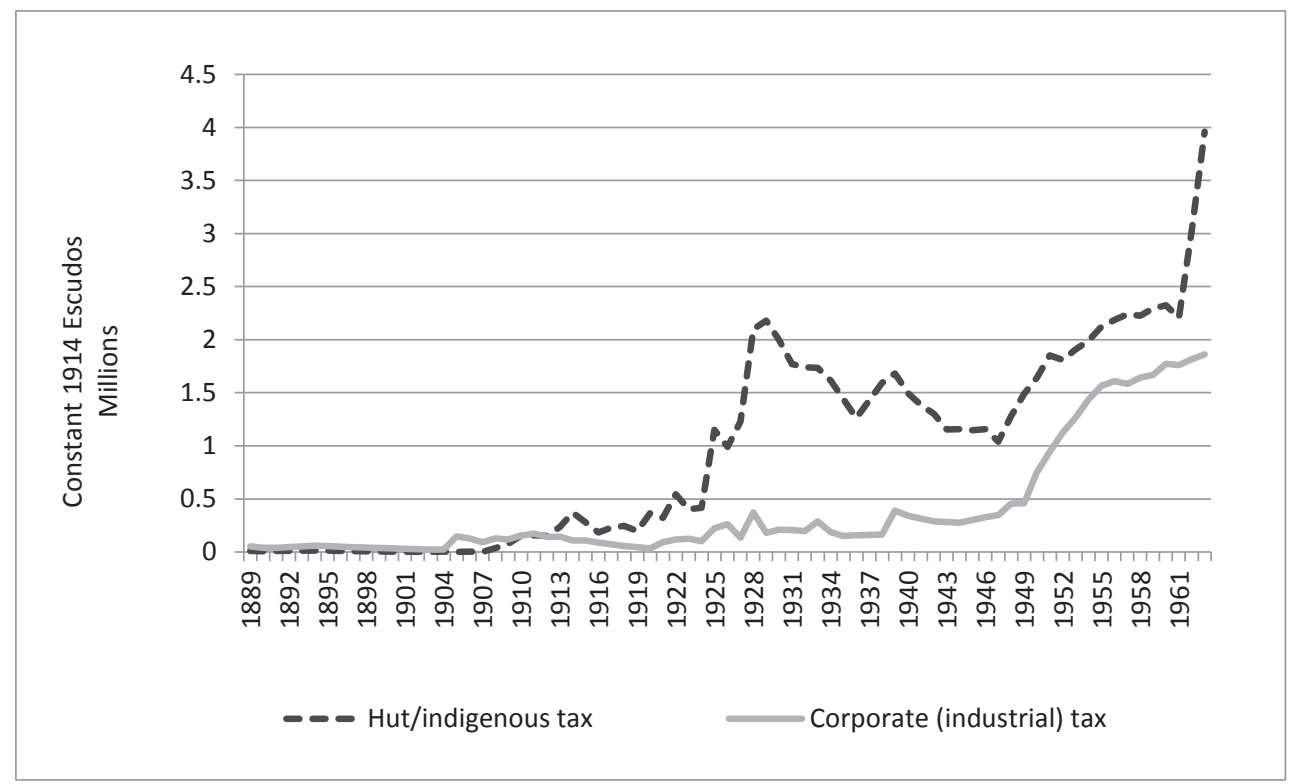

Sources: Boletim Official, various issues between 1880 and 1910; Colonia de Angola, Orçamento Geral, various issues between 1921-1941; Provincia de Angola, Contas da Gerência, various issues between 1931-1972; Price deflator: Valério and Tjipilica (2008).

Figure 5.10 shows real direct tax revenue in Angola. Indigenous taxes remained the most vital public revenue source up to the 1960 s, followed by taxes paid by the corporate (industrial) sector and individual entrepreneurs (usually white settlers). In the period 1920s-1940s the difference between the shares of these two types of taxation was huge, but gradually convergence was attained. Moreover, figure 5.11 displays a parallel rise of public ordinary expenditure on infrastructure, in line with the developments in Mozambique. Ordinary investments in infrastructure reached their peak (34\%) in the early 1960s. Growing infrastructural expenses in Angola were covered by both trade taxes and growing indigenous taxes (see chapter 2). 
Figure 5.11: Shares of public ordinary expenditure by category in Angola, 1932-1972

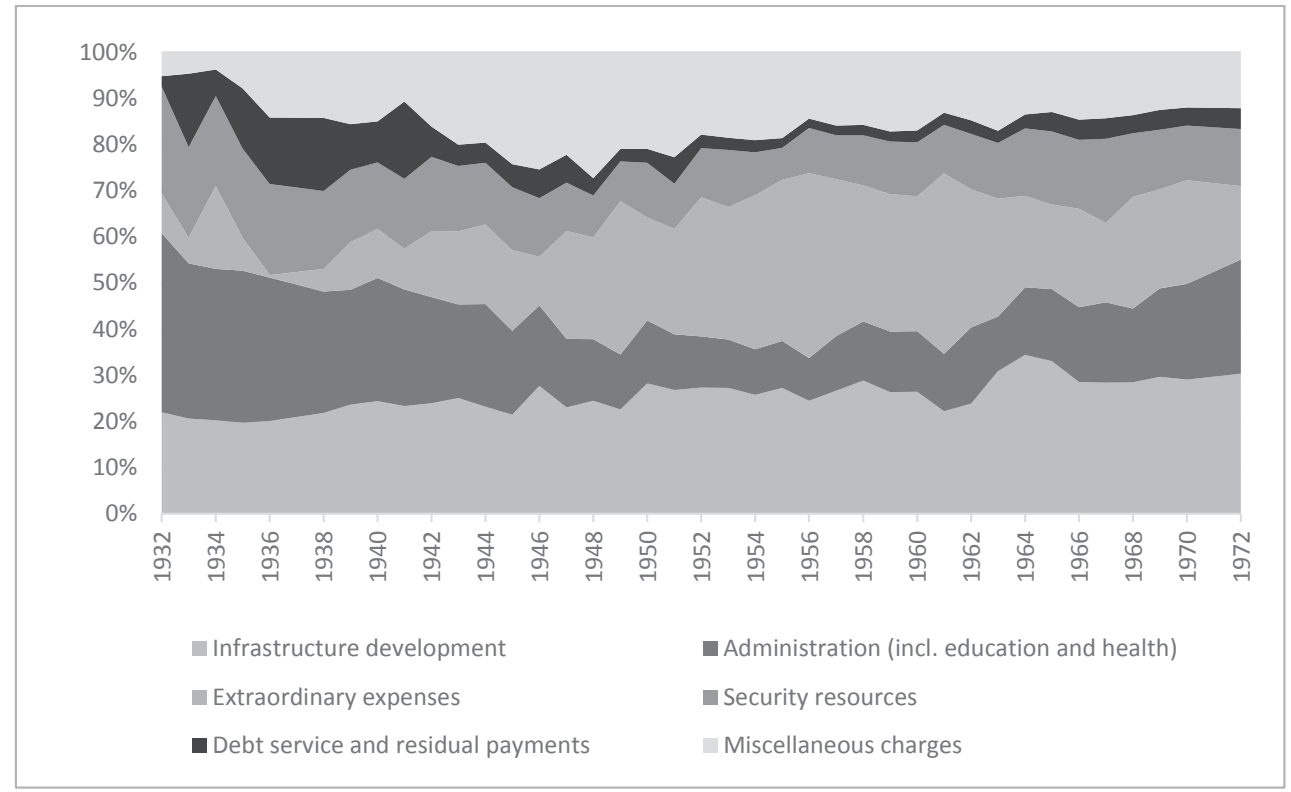

Source: Colonia de Angola, Repartição Central de Estatística Geral. Anuário Estatistico, various issues between 1932-1972; Price deflator: Valério and Tjipilica (2008).

As in Mozambique, the remaining ordinary revenue was spent on security forces, administration, including social services, debt service and residual payments from previous fiscal years. The extra-ordinary expenses were covered by metropolitan loans and subsidies. The latter were substantial in the case of Angola, particularly during the Republican era (late 1910s and 1920s). Colonial budgets of the period 1921-29 show that extraordinary revenue and expenditure consisted mainly of loans that were taken for infrastructure purposes. In 192324 almost half of Angola's budget consisted of extraordinary sums: 83 out of 204 million Escudos in total were spent primarily on ports and railways and secondarily on other public works, communication and agricultural projects (Direcção dos Serviços de Fazenda e Contabilidade 1923-24, p.35). The lion's share was spent on Luanda Railway and port of Lobito.

Colonial budgets demonstrate that during the years up to the global economic crisis (1926-30) Angola's fiscal deficit was mounting and in parallel, indigenous taxation and ordinary expenditure on public works were rising. In reality, after the regime change in 
Portugal, a 1926 decree distinguished ordinary expenditure and revenue from extraordinary ones as completely separate budgets. Colonial officials started recording extraordinary revenue and expenditure separately, revealing the colony's deficit. Due to harsh austerity measures taken by Salazar's regime, the deficit soon settled and development projects would be amortized in longer terms (in 10 years). Loans were preferably contracted within the colony or the metropole and had to be paid out of the colonial budgets, making use of direct and indirect tax revenue.

\subsection{Conclusion}

In some cases the colonial governments of Mozambique and Angola and the metropole succeeded to attract domestic private capital to invest in railways, but in most cases railway building took a long time between study plan and inauguration. In the introduction of this chapter I posed the question of how we can explain that the railway network in Portuguese Africa expanded in line with neighbour colonies, while possibilities to attract capital in Portugal were smaller than in wealthier metropoles such as Britain, France and Belgium. To answer this question, this chapter has explored the political economy of railway construction in Portuguese Mozambique and Angola from the 1880s to 1970 s and investigated the interaction of metropolitan, colonial, indigenous and foreign (e.g. British) actors with different interests.

The infrastructural investments and railway expansion in Portuguese Africa depended on three key factors: first, the involvement of international (British/Belgian) interests in constructing lines connecting the main mineral export areas to the coast; second, the extensive use of extractive and coercive institutions such as forced labour and native taxation; and third, the metropolitan policies that demanded the growth of settler areas and consequently the strengthening of local cash crop exports. At times the railway network was developed in harmony and at times in conflict with British interests. When mineral freight was at stake, private investors stepped in more easily. The colonial governments, however, had a broader agenda: they aimed at effectively occupying hinterland, creating new settler communities and increasing consent of the governed, by improving their living conditions.

Especially for the colonial state of Angola, railways would penetrate the hinterland and decrease the risks of both external threats and internal revolts. By the 1930s, infrastructure was still concentrated around urban, white settled areas, neglecting the remote rural areas inhabited by the vast majority of native Africans. Railways, however, required large investments and 
many lines needed additional financial support, which was difficult to obtain in international credit markets. After Salazar rose to power (1930s), the Portuguese states took over the operation of most railway lines in the two colonies and funded them either out of their ordinary colonial budgets or via loans usually raised in the metropole.

In both colonies the construction of the lines relied heavily on indigenous Africans, who were either part of forced labour schemes or worked as wage workers. Africans also contributed considerable amounts of hut and poll taxes to finance infrastructural expenses (or service debts incurred on loans for infrastructure), including a number of failed projects. In Mozambique this tax burden was heaviest, as Angola could rely more on private investors (i.e. the Benguela Railway) and indirect taxes on exports and imports to fund infrastructure. Extractive mechanisms continued to be used to foster infrastructure development up to the late colonial era.

The desired transformation of Portuguese African societies from coercive into developmental states, that the metropole envisioned -especially during Republicans' governance in 1911-1926 (see chapters 1 and 2)- was thus jeopardized by the very means of 'development'; except perhaps for a very short interval in the late colonial era, when forced labour ended under increasing pressure both by the international community and the African independence movements. 


\section{Chapter 6. Conclusions}

In this thesis I have studied colonial state formation and fiscal regimes in the two main Portuguese colonies of Mozambique and Angola. The Portuguese presence in Africa lasted over five centuries, starting from the explorations in the $15^{\text {th }}$ century and the creation of trade posts on the coastline of Africa during the $16^{\text {th }}-18^{\text {th }}$ centuries. However, the colonization of African territories officially started during the so-called Scramble for Africa in the $19^{\text {th }}$ century. The period under examination in this thesis spans from the first Portuguese military expeditions to occupy the coastal regions of South-Western and South-Eastern Africa in the 1850s-1880s to the era of independence, granted by Portugal to Mozambique and Angola after a long colonial war in the 1960s-1970s.

The three key questions that I posed in the introduction of this thesis are: first, how a weak metropolitan power such as Portugal managed to occupy the African territories of Angola and Mozambique, establish fiscal systems and eventually maintain its colonies for such a long period; second, to what extent the two Portuguese colonies were representative for general patterns of colonial state formation in Sub-Saharan Africa, and to what extent they formed exceptional cases; third, how extractive, minimalist or developmental the colonial states of Mozambique and Angola were in different phases of Portuguese rule.

To answer these questions, I have conducted a two-fold comparison: first, between the two colonies Mozambique and Angola, which allowed me to isolate the effects of local conditions in the process of colonial state formation; and second, between Portuguese Africa as a whole and the parts of British Africa and, wherever possible, parts of French and Belgian Africa as well. The latter comparative perspective allowed me to gain deeper insight in the specific effect of metropolitan identity (i.e. ideologies, policies, power and economic structure) on the process of colonial state formation in Angola and Mozambique.

In contrast with previous studies (Havik 2013, Havik et al. 2015), this thesis has presented not only comparative data on taxation patterns and non-tax revenue sources, but also on public expenditure priorities, and investment policies and practices. I have assessed the impact of metropolitan visions and local African conditions on the design of fiscal institutions and explored the main drivers of state and fiscal strength or weakness; in other words, the main structural characteristics of both Portugal and its African colonies; such as the economic and diplomatic metropolitan power, the degree of political and administrative centralization of the 
Portuguese Empire as a whole, the geographic position and the socio-economic integration of the colonies, access to factor endowments (i.e. land, labour and capital) as well as natives' resistance or consent. Here I present the main conclusions upon the features of colonial state and fiscal institutions in Portuguese Africa as well as the major transformations of both states and fiscal regimes over time.

\subsection{Portuguese Africa: an exceptional case of extractive minimalism}

Portugal was a weak metropolitan power compared to other powers such as Britain, France and Belgium. In the 19th century it had a weakly developed industrial base and its political and diplomatic weight were relatively low in the international arena. During the Scramble for Africa, Portugal could secure its military and economic interests only by forming alliances with major powers such as Britain. After securing the territories of Mozambique and Angola at the negotiation table during the Berlin Conference (1884/85), Lisbon had to extend and consolidate its power over the hinterlands of its coastal possessions. Military occupation was a long interrupted process and was never fully completed. Changing coalitions of African kings and tribal chiefs in Angola adopted strategies of resistance and cooperation, while certain groups of Portuguese settlers, such as the prazeros in central Mozambique, were also opposed to the expansion of metropolitan control.

Organizing security forces, setting up administrations and transportation infrastructures as well as education and health services required sizeable investments. Metropolitan subsidies were not sufficient to cover the rising cost of the incipient colonial state and in so far colonial control of both territories remained partial, the tax base remained constrained. Therefore, in the early colonial era, the Portuguese government partly outsourced the cost of maintaining colonies in Africa, by offering concessions to companies, which collected taxes and invested in plantation agriculture and infrastructure. A prominent example was Companhia de Moçambique, which controlled large parts of the central zone of Mozambique. Colonial states in Africa were also able to outsource part of the cost of education and health facilities by cooperating with Catholic missions. However, this also meant that certain areas were not centrally administered and metropolitan regulations, for instance on labour, were frequently violated by private actors. Regions that lacked pre-colonial socio-economic and cultural integration continued to be fragmented (see chapter 3). Overall, colonial states and particularly Portuguese states in Africa were founded and built on a fragile basis. 
The colonial states of both Mozambique and Angola could become stronger within their jurisdiction, either by using coercion to enforce law or by increasing consent of the governed and improve state-society relations. From the empirical evidence presented in this thesis, I draw the conclusion that Portugal widely used coercive institutions to enforce law in its African colonies, exactly because it was weaker than the other metropolitan powers in economic and diplomatic terms (see chapters 4 and 5). As mentioned in the introduction, I have built on the work of Solli and Leysens (2011) on "the strong/weak state contradiction" in post-colonial Angola, by providing new evidence to indicate the colonial origins of this paradox, in a context of path dependence. Both quantitative and qualitative information analyzed in the previous chapters has shown that high levels of native taxation as well as forced labour considerably contributed to colonial budgets, either by securing public revenue or by saving expenditure. Via indigenous taxation and coercive labour Portuguese states of Mozambique and Angola achieved military control of the territories, expanded administration and upgraded colonial infrastructures.

Specifically, the early colonial era (1850s-1920s) has been characterized by a combination of minimalist and extractive fiscal regimes in Portuguese Mozambique and Angola, which aimed at securing internal order at minimum cost and at extracting resources via forced labour services and army recruitment as well as native taxation whenever needed (i.e. war periods or periods of railway building). Conversely, the late colonial era (1930s-1960s) is indicated by an incomplete transition from fiscal minimalism to more developmental policies, whose objectives were never fully realized. It might seem paradoxical that I consider the period of Republican governance (1911-1926) in Portugal as part of the "minimalist-extractive" phase in Portuguese Africa, while I consider the Salazar's New State (1933-1968) as part of the "minimalist-developmental" phase. After all, it is commonly accepted that the Republicans (for instance the progressive governor Norton de Matos in Angola) intended to foster a developmental agenda in Portuguese Africa, as administrative reports and parliamentary discussions reveal. However, there was a pressing need for the metropole in the 1910 s to make colonies financially self-sufficient. Thus, the colonial states needed to find alternative funding sources (i.e. the revenue imperative) and raise not only indirect but also direct taxes. In contrast, Salazar in principle aimed at fiscal consolidation and budget balance via austerity. Therefore, the post-1930s fiscal systems of Mozambique and Angola were de jure minimalist and only during the six-year development plans (planos do fomento) subsidized by the Portuguese government in the 1950s-1960s, they could be characterized as developmental. Nevertheless, native taxation and forced labour were used almost throughout the colonial era. Consequently, 
the fiscal regimes of Portuguese states in Africa were de facto extractive. Only in 1960, the Indigenato system (colour bar) ended and forced labour was banned.

In Chapter 2 I have shown that the identity and the features of the metropole mattered for the (under)development of the African colonies. The metropolitan visions and regime changes in Portugal were decisive in the reform of colonial fiscal policies. Local conditions and disparities between and within the colonies also mattered. For instance, in Angola indirect taxes were a major source of revenue for the state, while in early $20^{\text {th }}$ century Mozambique, flat (nonprogressive) indigenous taxation gradually became the most important source of public income. In Mozambique the share of revenue derived from native taxation started rising earlier than in Angola for three reasons: First, Mozambique's international trade volumes were substantially smaller than Angola's lucrative mineral exports (diamonds and copper). Hence, opportunities to finance state formation on the basis of indirect tax revenue were much more limited. Second, Portuguese military campaigns in Angola lasted longer and some regions were occupied as late as 1920 , due to strong native resistance; therefore, direct tax collection mechanisms developed later than in Mozambique. Third, Mozambique's budget benefited from the circular labour migration from the southern zone of the colony to South Africa and Southern Rhodesia, as returning migrants were able to pay monetized taxes at the border or in their home villages. Most importantly, chapter 3 has shown that the patterns of labour migration, revenue composition and tax inequality were highly path-dependent.

Chapter 4 has shown that spending on military forces dominated the early colonial state accounts, especially in Angola. Even though British African states could amass more militarily power than Angola or Mozambique, they tended to spend much less on their armed forces. Moreover, the armies in Portuguese Africa were larger in size and recruitment policies relied extensively on coercion, rather than on voluntary service. Nevertheless, chapter 4 deconstructs the stereotype -reproduced by scholars such as Fergusson (2002)- of 'benign' British rule as opposed to 'oppressive' Portuguese colonialism, arguing that Portuguese Africa could not benefit from the economies of scale and scope inherent to securing the global empires of Britain and France. Portugal had to secure two isolated coastal colonies, while Britain could exchange troops more easily, disseminate the skills of army trainers and rely more on credible deterrence to secure its territories. ${ }^{121}$ The heavy public expenditure on security diminished the possibility

\footnotetext{
${ }^{121}$ As Jerónimo has stated "the military incursions that formed the occupation movements of the socalled pacification campaigns between c.1890 and c.1926 were as much a sign of the fragility of the political, economic and social backbones of the empire as they were a demonstration of power" (2013, p.74).
} 
of the colonial states of Mozambique and Angola to invest in welfare services such as education and health care.

Furthermore, apart from a limited number of metropolitan subsidies, infrastructure and transportation were principally funded out of the ordinary colonial budgets or via loans usually raised in the metropole. Chapter 5 sheds light on the construction, financing and operation of railways, which were the most significant means of transportation during the colonial era. In both colonies the construction of the railways relied heavily on African labourers, who were either forcibly recruited or worked as wage workers. Africans also paid substantial amounts of hut and poll taxes to finance infrastructural projects (or service the debts incurred through infrastructural investments). In Mozambique this tax burden was heavier, as Angola could rely more on private capital investment (i.e. the Benguela Railway) and indirect taxes on trade to fund infrastructure.

Only in the late colonial years (from 1953 onwards), under the pressure of international organizations and African independence movements, the metropolitan and colonial governments implemented development plans aimed at improving the living conditions of both white settlers and African populations. However, the desired -by the metropole- transformation from coercive into developmental colonial states continued to be jeopardized by the very means of 'development'. Instead of fostering consensus-based development to actively involve African communities in the realms of colonial governance, Portuguese Angola and Mozambique promoted state-driven development projects, excluding indigenous people from decision-making while exploiting African manpower and raising revenue from native taxes. Extractive institutions in the framework of Indigenato, with respect to land, labour and taxation affairs, continued to be in place up to 1960 , when full citizenship was finally granted to all imperial subjects.

This conclusion is in line with previous literature on "repressive developmentalism" in Africa (Cooper 2012 p.62, Jerónimo 2013 pp.88, 91), at the end of Empire. According to Jerónimo, "repressive developmentalism" consisted of the following elements: increasing migration of colonos (rural settlers) from Portugal to its African colonies after the WWII; topdown formation of aldeamentos (protected white settler or racially mixed villages); population control and surveillance mechanisms; as well as growing investments in public works and communications. In parallel, the statistical and intelligence agencies that gathered information on colonial administration, production, trade, infrastructure etc. were facilitated by ongoing technological and scientific developments and secured the Portuguese Empire from internal and external threats. The "empire of information" was, according to Jerónimo, the backbone of 
repressive developmentalism. The latter intensified through the militarisation of the Portuguese states in Africa due to the independence wars in the 1960s-1970s (2013, pp.89, 91).

Following Frankema (2011, p.138), I prefer to classify the fiscal regimes of Portuguese Mozambique and Angola as predominantly "extractive-minimalist", because even if there was a developmental agenda at stake in certain periods (1910s, 1950s), the largest part of the colonial era (especially during Salazar's New State) fiscal regimes in both colonies were in theory characterized by minimalist principles (such as budget balance and debt elimination), while in practice direct and indirect extractive mechanisms were in use. As previous literature has shown, the extractive mechanisms included not only the control over imperial trade, but also specifically exploitative labour and fiscal institutions (Penvenne 1995, Ball 2005, Havik et al. 2015). The relationship of Portugal and its African colonies from a global perspective consisted of mineral resource exploitation, re-export of raw materials (cotton) and tropical commodities via Portugal (Lains 1998), import of processed goods (wine, textiles) into the African colonies and the creation of new markets for European manufactures.

To conclude, in this thesis the exceptionality of Portuguese colonialism in Africa does not derive from the belief that due to a long-lasting co-existence of Portuguese settlers and native populations, there was more social equality or at least cultural integration in Lusophone Africa than in British and French Africa, as the defenders of "Lusotropicalism" have argued (see also the critique by Castelo 2011). The empirical evidence presented in the previous chapters demonstrated that Portuguese colonialism in Africa was exceptional in the sense that a weak metropolitan power managed to sustain its authority as late as the 1970s, by building minimalist and extractive fiscal states that did not develop into welfare states even during the global post-war boom. The colonial states of Mozambique and Angola -despite their differences driven by local conditions- were both based on extreme securitization and outsourcing of the imperial costs.

\subsection{Future research agenda}

Nowadays Mozambique and Angola are considered fragile or even failed states. This study and especially chapters 3 and 4 have important implications for the understanding of state capacity building and fiscal developments in post-colonial Africa. As the example of Mozambique indicates, fiscal regimes have been highly path-dependent. A wide range of pre-colonial and colonial factors played a role in their (trans)formation. I do not claim that this thesis has offered 
evidence for generalizable laws of colonial state formation that links metropolitan identity and local conditions to certain types of fiscal institutions. However, the key quantitative and qualitative data presented in this thesis offer a good starting point for future research on state and fiscal transformation in post-independence Africa. Was African independence a real rupture or can considerable continuities be observed? This is a question that is worth to be investigated further.

Furthermore, the variation across different African regions and the long-term legacies of the differences between former Portuguese, British, French, Belgian and German colonies have not yet been thoroughly studied. For instance, why were the civil wars in Mozambique, Angola and Zaire/DRC among the most prolonged and intensive conflicts that broke out after the wave of independence in the early 1960s? What about the long-term consequences of extreme securitization of Portuguese Africa and the accumulated investments in non-productive resources such as military equipment?

In addition, future research could further investigate forced and child labour, as tools of colonial states and companies to save on expenditure (Van Waijenburg 2018). Most studies on forced labour in Portuguese Africa make use of oral testimonies and focus on the micro-history of a spatially restricted area (Ball 2015). In chapter 5 I have approximately estimated the share of the total labour cost covered by forced labour schemes in the railway construction in northern Mozambique. However, I have not been able to quantify the magnitude of forced labour at national level in the long-run. Since aggregate statistics on coercive labour are absent, the only way to proceed is to pay long visits to the archives of Mozambique and Angola, dive into a bulk of scattered documents (such as local administrative reports and correspondence) and set up new methods to quantify the extent of forced labour.

This thesis discussed the low level of state investments in welfare services in both colonial Mozambique and Angola, compared to British or French Africa. Those low welfare investments had implications for human capital formation in former Portuguese Africa. As mentioned in chapter 2, at the end of Portuguese colonialism, a very limited number of Angolan and Mozambican citizens were educated at college or university level, while illiteracy levels were very high among the native African population. Nowadays Angola and especially Mozambique still rank low in education indexes of the United Nations, however schooling rates have been constantly rising since 1980. In this framework, it would be fruitful to study, first, the involvement of other historical actors in education and health services, namely religious missions and private companies; and second, the long-term impact of Portuguese colonialism 
on human capital, literacy and numeracy skills of indigenous population in Africa. Population censuses, slave and military registries may be collected for this purpose.

Finally, it is worth to further explore the role of imperial and colonial statistics in the consolidation of Portuguese rule in Africa. How were statistics produced and what was their impact on changing fiscal policies and practices? On top of that, it would be interesting to draw parallels and identify differences between former imperial agents and current international organizations such as IMF and World Bank. These organizations collect data and produce statistics, on the basis of which aid and development policies are designed and implemented in various developing regions, including former Portuguese Africa. It would be intriguing to investigate not only potential trends and cycles in the economic performance of former colonies and developing countries, but also how indicators of economic development and state performance are constructed in the first place. What are the criteria according to which economies' and states' capacity is measured and how are development policies and projects assessed? This is a highly interdisciplinary field that requires the cooperation of historians, political scientists, economists and anthropologists. Research in this field can shed more light on the long-term institutional path-dependencies, when colonial states transform into sovereign states. 


\section{Published primary sources}

Aguiar (n.d.). F. R. de. Imposto de palhota. Distrito de Lourenço Marques.

Angola - Repartição Técnica de Estatística Geral (1954). Estatística das Contribuições e Impostos. Luanda: Imprensa Nacional.

British Foreign \& Commonwealth Office (1821-1953). African Blue Books. London: Microform Academic Publishers.

Cayolla, L. (1912). Sciencia de colonisação (Vol. 1). Lisboa: Typographia da Cooperativa Militar.

Castro, A.A.G. de Morais e, (1948). Economia, Finanças e Geografia Económica. Ligeiro esboco histórico do sistema de pagamento de imposto na colonia de Angola. Mensário administrativo: publicação de assuntos de interesse ultramarino / direcção dos Serviços de Administração. No 14, 37-40.

Colonia de Angola (1921-1941). Orçamento Geral. Luanda: Imprensa Nacional.

Colonia de Angola, Repartição Central de Estatística Geral (1933-1973). Anuário Estatistico. Luanda: Imprensa Nacional.

Colonia de Moçambique (1946). Legislação sobre Imposto Indígena. Lourenço Marques: Imprensa Nacional de Moçambique.

Colonia de Moçam bique (1912-1941). Orçamento Geral. Lourenço Marques: Im prensa Nacional.

Colonia de Moçambique, Repartição Central de Estatística Geral (1926-1973). Anuário Estatístico. Lourenço Marques: Imprensa Nacional.

Costa, E. (1902). O Território de Manica e Sofala e a Administração da Companhia de Moçambique, 1892-1900. Lisboa: Typographia da Companhia Nacional Editora. 
Dias Costa, Francisco Felisberto (1898a). Relatório do Ministro e Secretario d'Estado dos Negócios da Marinha e Ultramar apresentado a Camara dos Senhores Deputados na Sessão Legislativa de 1898. Lisboa: Imprensa Nacional.

Dias Costa, Francisco Felisberto (1898b). Regulamento Orgânico da Guarda Fiscal nos Territórios da Companhia de Moçambique approvado por Decreto de 12 de Maio de 1898, Lisboa: Imprensa Nacional.

Direcção dos Caminhos de Ferro de Loanda. (1909). Monographia do Caminho de Ferro de Malange. Loanda: Imprensa Nacional.

Direcção dos Serviços de Fazenda e Contabilidade (1923-24). Orçamento geral de Angola. Luanda: Imprensa Nacional.

Enes, A. (1946). Moçambique: relatório apresentado ao governo. Lisboa: Divisão de Publicações e Biblioteca, Agência Geral das Colónias.

Governo Geral da Provincia de Moçambique (Various issues between 1850 and 1910). Boletim Official. Lourenço Marques: Imprensa Nacional de Moçambique.

Governo Geral de Angola - Secretaria Geral (1920). Regulamento do recenseamento e cobrança do imposto indígena. Loanda: Imprensa Nacional.

Melo, A.A.G. (1953). Economia e Finanças. Noticia dos impostos lançados sobre os indígenas angolenses desde os tempos da conquista ate hoje.

Ministerio dos Negocios da Marinha e Ultramar (1909). Caminho de ferro de Loanda a Ambaca: : Relatorio acêrca da situação da Companhia Real dos Caminhos de Ferro através de Africa e da proposta d'esta para a entrega do caminho de ferro ao Estado. Lisboa: Imprensa Nacional.

Monteiro, Manuel (1941, de Junho). “A Evolução do Mecanismo Pautal Ultramarino durante um Seculo". In: Boletim Geral das Colonias. (No.192), 43-86.

Pimentel, F. (1892). Apontamentos para a história dos Caminhos de Ferro Portugueses. Lisboa: Typographia universal.

Província de Angola (1918). Legislação administrativa. Loanda: Imprensa Nacional. 
Província de Angola, Direcção dos Serviços de Fazenda e Contabilidade (1931-1972). Contas da Gerência. Luanda: Imprensa Nacional.

Provincia de Moçambique (1904, 30 de Novembro). Regulamento para o Recrutamento das Forcas Indigenas. Portaria provincial no 859-A. Lourenço Marques: Imprensa Nacional.

Província de Moçambique, Direcção dos Serviços de Fazenda e Contabilidade (1934-1973). Contas da Gerência. Luanda: Imprensa Nacional.

Provincia de Moçambique, Repartição Superior de Fazenda (1908). Estatística dos Rendimentos da Provincia. Annos de 1897-1898 a 1906-1907. Lourenço Marques: Imprensa Nacional.

Questão do Caminho de Ferro de Ambaca: Relatório da commissão mixta nomeada por portaria de 21 de Março de 1912 para estudar a melhor solução do assunto. (1913). Lisboa: Imprensa Nacional.

República Portuguesa, Govérno Geral de Angola (1914, 13 de Fevereiro). Regulamento dos servicos de recrutamento indígena. Portaria Provincial no 206. Loanda: Imprensa Nacional.

Salvagem, C. (1931). Portugal militar: compêndio de história militar e naval de Portugal: desde as origens do Estado portucalense até o fim de Bragança. Imprensa Nacional-Casa de Moeda.

Vasconselos, A.B. de (1948). Caminhos de Ferro de Moçambique. Porto: Tipografia invicta.

Vasconselos, E. de. Sociedade de Geografia de Lisboa (1920). Questões Coloniais e Económicas: Conclusões e Pareceres 1913-1919. Lisboa: Topografia da Cooperativa Militar.

\section{Unpublished archival sources}

Boletim Official da Colonia de Moçambique (1928, 19 de Setembro). Suplemento: Convenção entre o Governo da Republica Portuguesa e o Governo União da Africa do Sul. I Serie, No 37. Lisboa: Arquivo Histórico Ultramarino (AHU).

Cabral, G. (1924). Algumas verdades sobre as Variantes do Caminho de Ferro de Loanda. 
Direcção dos Serviços de portos, Caminhos de Ferro e Transportes (1949). Caminho de Ferro de Moçâmedes. Luanda: Arquivo Histórico Colonial.

Freire d'Andrade, A. (1928). Resumo do relatório ao Ministro das Colonias. Lisboa: Arquivo Histórico Ultramarino (AHU).

Inspecção superior dos negócios indígenas (1951). Lourenço Marques: Arquivo Histórico de Moçambique (AHM).

Memoria explicativa e descriptiva dos actos e da situação da companhia real dos caminhos de ferro atravez d'Africa. (1900). Lisboa: Officinas do Commercio do Porto.

The Star (13.7.1933). Union relations with Mozambique. To press for changes in the Convention. Mines and Railways handicapped. Lisbon: Arquivo Histórico Ultramarino (AHU).

\section{Secondary literature}

Acemoglu, D., Johnson, S., \& Robinson, J. A. (2001). "The colonial origins of comparative development: An empirical investigation". American economic review, 91(5), 1369-1401.

Acemoglu, D., \& Robinson, J. A. (2013). Why nations fail: The origins of power, prosperity, and poverty. Broadway Business.

Albers, T. and Suesse, M. (2015). "Colonial Fiscal Institutions in Africa: How They Persisted, When They Changed, and Why", unpublished working paper.

Alexopoulou, K. (2019, forthcoming). "Local conditions and metropolitan visions. Fiscal policies and practices in Portuguese Africa, 1850s-1970s". In: Ewout Frankema and Anne Booth (eds.). Fiscal capacity of colonial states in Asia and Africa. Cambridge University Press.

Alexopoulou, K., \& Juif, D. (2017). “Colonial State Formation Without Integration: Tax Capacity and Labour Regimes in Portuguese Mozambique (1890s-1970s)". International Review of Social History, 62(2), 215-252. 
Allina, E. (2012). Slavery by any other name: African life under company rule in colonial Mozambique. Charlottesville and London: University of Virginia Press.

Allina, E. (1997). "Fallacious Mirrors: Colonial Anxiety and Images of African Labor in Mozambique, ca. 1929”. History in Africa, 9-52.

Amin, S. (1972). "Underdevelopment and dependence in Black Africa-origins and contemporary forms". The Journal of Modern African Studies, 10(04), 503-524.

Anderson, B. (1987). Imagined communities: Reflections on the origin and spread of nationalism. Verso Books.

Anderson, P. (1962). "Portugal and the end of ultra-colonialism". New Left Review, (15).

Andersson, J. (2017). "Long-Term Dynamics of the State in Francophone West Africa: Fiscal Capacity Pathways 1850-2010”. Economic History of Developing Regions, 32(1), 37-70.

Arrifes, M.F. (2004). A Primeira Guerra Mundial na África portuguesa: Angola e Moçambique (1914-1918). Lisboa: Edições Cosmos, Instituto da Defesa Nacional.

Austin, G. (2008a). "Resources, techniques, and strategies south of the Sahara: revising the factor endowments perspective on African economic development, 1500-2000". The Economic History Review, 61(3), 587-624.

Austin, G. (2008b). "The 'reversal of fortune' thesis and the compression of history: perspectives from African and comparative economic history". Journal of International Development: The Journal of the Development Studies Association, 20(8), 996-1027.

Austin, G., Frankema, E.H.P., \& Jerven, M. (2017). "Patterns of Manufacturing Growth in SubSaharan Africa". In The Spread of Modern Industry to the Periphery since 1871. Oxford University Press.

Azambuja Martins, E.M. (1939). "Estudo demografico indigena em Mocambique”. Revista Militar, (8), 569-596.

Ball, J. (2015). Angola's colossal lie: forced labor on a sugar plantation, 1913-1977. Boston: Brill. 
Bastos, C. (2008). "Migrants, settlers and colonists: the biopolitics of displaced bodies". International Migration, 46(5), 27-54.

Baten, J., \& Fertig, G. (2009). "Did the railway increase inequality? A micro-regional analysis of heights in the hinterland of the booming Ruhr area during the late nineteenth century". The Journal of European Economic History, 38(2), 263.

Bayart, J.F. (1993). The state in Africa: The politics of the belly. London: Longman.

Bender, Gerald J. (1978). Angola under the Portuguese: the myth and the reality. Berkeley: University of California press.

Besley, T., \& Persson, T. (2010). "State capacity, conflict, and development". Econometrica, $78(1), 1-34$.

Bloom, D.E., Sachs, J. D., Collier, P., \& Udry, C. (1998). "Geography, demography, and economic growth in Africa". Brookings papers on economic activity, (2), 207-295.

Bodin, J. (1993). Les six livres de la République: : un abrégé du texte de l'édition de Paris de 1583. Paris: Librairie Générale Française.

Boege, V., Brown, M. A., \& Clements, K. P. (2009). "Hybrid political orders, not fragile states". Peace Review, 21(1), 13-21.

Booth, A. (2007). Colonial legacies: Economic and social development in East and Southeast Asia. University of Hawaii Press.

Bowen, M.L. (2000). The state against the peasantry: Rural struggles in colonial and postcolonial Mozambique. University of Virginia Press.

Brautigam, D., Fjeldstad, O.H., \& Moore, M. (eds.). (2008). Taxation and state-building in developing countries: Capacity and consent. Cambridge University Press.

Bravo, N.S. (1963).“A cultura algodoeira na economia do norte de Moçambique”. Junta de Investigações do Ultramar, Centro de Estudos Políticos e Sociais, Lisboa.

Buckwalter, L.M. (2017). Essays on economic development: pre-independent Algeria at the beginning of the 1900s (Doctoral dissertation, Madrid: Universidad Carlos III de Madrid). 
Buggeln, M., Daunton, M.J., \& Nützenadel, A. (2017). The political economy of public finance: Taxation, state spending and debt since the 1970s. Cambridge: Cambridge University Press.

Bush, B. and J. Maltby (2004). "Taxation in West Africa: Transforming the colonial subject into the "governable person"." Critical Perspectives on Accounting 15(1), 5-34.

Cain, P. J., \& Hopkins, A. G. (2001). British imperialism, 1688-2000. New York: Longman.

Campbell, J. L. (1993). "The state and fiscal sociology". Annual Review of Sociology, 19(1), $163-185$.

Capela, J. (1979). As burguesias portuguesas e a abolição do trafico de escravos, 1810-1842. Porto: Afrontamento.

Cardoso, J.L., \& Lains, P. (2010). "Public Finance in Portugal, 1796-1910”, in J. L. Cardoso and P. Lains (eds.) Paying for the liberal state: the rise of public finance in nineteenth-century Europe. Cambridge: Cambridge University Press, 251-278.

Carrilho, M. (1985). Forças armadas e mudança política em Portugal no séc. XX: para um explicação sociológica do papel dos militares. Imprensa Nacional-Casa da Moeda.

Castelo, C. (2007). Passagens para África: O povoamento de Angola e Moçambique con naturais da metrópole (1920-1974). Porto: Afrontamento.

Castelo, C. (2011). O modo portugués de estar no mundo: O luso-tropicalismo e a ideología colonial portuguesa (1933-1961). Porto: Edições Afrontamento.

Chibber, V. (2014). Postcolonial theory and the specter of capital. Verso Books.

Chilundo, A.G. (2001). Os camponeses e os caminhos de ferro e estradas em Nampula (19001961). Promédia.

Clapham, C. (2001). "Rethinking African States”. African Security Studies, 10(3), 6-16.

Clarence-Smith, W.G. (1987). "The imperialism of beggars": the role of the less developed powers in the nineteenth century scramble for colonies, Institute of Commonwealth Studies, Collected Seminar Papers, The City and Empire, 2, 94-100. 
Clarence-Smith, W.G. (1985). The third Portuguese empire, 1825-1975: a study in economic Imperialism. Manchester University Press.

Clarence-Smith, W.G. (1979). "The myth of uneconomic imperialism: The Portuguese in Angola, 1836-1926”. Journal of Southern African Studies, 5(2), 165-180.

Clarence-Smith, W.G. (1977). "For Braudel: A Note on the 'Ecole des Annales' and the Historiography of Africa". History in Africa, 4, 275-281.

Cleveland, T.C. (2008). Rock solid: African laborers on the diamond mines of the Companhia de Diamantes de Angola (Diamang), 1917-1975. University of Minnesota.

Coelho, J.P.B. (2002). "African troops in the Portuguese colonial army, 1961-1974: Angola, Guinea-Bissau and Mozambique”. Portuguese Studies Review, 10(1), 129-150.

Cogneau, D., \& Moradi, A. (2014). "Borders that divide: Education and religion in Ghana and Togo since colonial times”. The Journal of Economic History, 74(03), 694-729.

Cogneau, D., Yannick Dupraz, Sandrine Mesplé-Somps (2018). "Fiscal Capacity and Dualism in Colonial States : The French Empire 1830-1962.” PSE Working Papers n²018-27.

Collier, P. and Sambanis, N. (2005). Understanding Civil War: Evidence and Analysis, Volume 1: Africa. Washington: World Bank Publications.

Conceição, Lourenço Mendes da (1967). Trinta e Quatro Anos de Administração Financeira a proposito do Orçamento Geral de Angola para 1965. Separata da Revista “Angola”, (174).

Cooper, F. (2002). Africa since 1940: the past of the present (Vol. 1). Cambridge University Press.

Cooper, F. (1996). Decolonization and African Society. The labor question in French and British Africa. Cambridge UK: Cambridge University Press.

Crowder, M. (1964). "Indirect rule, French and British style”. Africa, 34, 197-205.

Crush, J., Jeeves, A., \& Yudelman, D. (1991). South Africa's Labour Empire: History of Black migrancy to the Gold mines. Oxford: Westview Press. 
Da Silveira, Carlos Henrique Jones (1938, Julho de). "A defesa militar das colonias". Revista Militar, (7), 534-549.

Da Silveira, Carlos Henrique Jones (1938, Agosto de). “A defesa militar das colonias”. Revista Militar, (8), 587-614.

Davis, L.E., Huttenback, R.A. (1986). Mammon and the pursuit of Empire: The political economy of British imperialism, 1860-1912. Cambridge University Press.

De Matos, N. (1944). Memorias e Trahalhos de Minha Vida (Vol.II), Editora MaritimoColonial.

De Oliveira Marques, A.H.R. (2001). O império africano, 1890-1930 (Vol.3). Lisboa: Editorial Estampa.

De Roo, B. (2017) "Taxation in the Congo Free State, an exceptional case? (1885-1908)". Economic History of Developing Regions, 32:2.

Diamond, J. M. (1998). Guns, germs and steel: a short history of everybody for the last 13,000 years. Random House.

Diogo, M. P., \& van Laak, D. (2016). Europeans Globalizing: Mapping, Exploiting, Exchanging. Palgrave Macmillan.

Dincecco, M. (2011). Political transformations and public finances: Europe, 1650-1913. Cambridge: Cambridge University Press.

Dincecco, M. Fenske, J. and Onorato, M.G. (2014). "Is Africa Different? Historical Conflict and State Development", CSAE Working Paper WPS/2014-35.

Direito, B. (2013a). "Land and Colonialism in Mozambique-Policies and Practice in Inhambane, c. 1900-c. 1940". Journal of Southern African Studies, 39(2), 353-369.

Direito, B. (2013b). Políticas coloniais de terras em Moçambique: o caso de Manica e Sofala sob a Companhia de Moçambique, 1892-1942. (Doctoral dissertation. Lisbon: Lisbon University). 
Duarte, A.M.S.R. (2014). The Challenges of the "Development From Above" and "Development From Below" in the Lobito Transport Corridor (Angola). International Relations and Diplomacy.

Duffy, J. (1959). Portuguese Africa. Harvard University Press.

Dupraz, Y., Cogneau D. and S. Mesplé-Somps (2016). African states and development in historical perspective: Colonial public finances in British and French West Africa, paper presented at the $6^{\text {th }}$ annual meeting of the AEHN, Sussex University.

Durrant, A. E., Jorgensen, A. A., \& Lewis, C. P. (1981). Steam in Africa. Cape Town: C. Struik. Easterly, W. and Levine, R. (2012). 'The European Origins of Economic Development', NBER Working Paper 18162. Cambridge, MA: National Bureau of Economic Research.

Englebert, P. (2000). "Pre-colonial institutions, post-colonial states, and economic development in tropical Africa". Political Research Quarterly, 53(1), 7-36.

Esteves, E. (2008). “As Vias de Comunicação e Meios de Transporte como Factoresde Globalização, de Estabilidade Política e de Transformação Económica e Social: Caso do Caminho-de-ferro de Bengela (1889-1950)". In: von Oppen, A. and B. Heintze (eds.). Angola on the move: transport routes, communications and history. Frankfurt: Lembeck. pp. 99-129.

Esteves, E. (2000). “O caminho-de-ferro de Bengela e o Impacto Económico, Social e Cultural na sua Zona de Influencia (1902-1952)”. Africana Estudia, (3), 49-72.

Evans, P.B., Rueschemeyer, D., \& Skocpol, T. (eds.). (1985). Bringing the state back in. Cambridge University Press.

Fay, M., \& Opal, C. (1999). Urbanization without growth: a not-so-uncommon phenomenon. The World Bank: Policy Research Working Paper.

Feger, T., \& Asafu-Adjaye, J. (2014). "Tax effort performance in sub-Sahara Africa and the role of colonialism". Economic Modelling, 38, 163-174.

Feinstein, C.H. (2005). An Economic History of South Africa: Conquest, Discrimination, and Development. Cambridge University Press. 
Ferguson, N. (2002). Empire: The Rise and Demise of the British World Order and the Lessons for Global Power, New York: Basic Books.

Ferreira, Coronel Vicente (1932). A politica colonial Portuguesa em Angola. Coimbra: Imprensa da Universidade.

Ferreira, L., \& Pedra, C. (1988). "Despesas coloniais do Estado Português, 1913-1980". Revista de História Económica e Social, 24, 89-103.

Ferreirinha, F. (1947). "Antonio Enes e o seu pensamento colonial”. In: Sociedade de Estudos da Colonia de Moçambique. Teses Apresentadas ao lo Congresso realizado de 8 a 13 de Septembro de 1947 (Vol.1). Lourenço Marques: Tip. Minerva Central.

Fieldhouse, D.K. (1961). “'Imperialism': an historiographical revision”. The Economic History Review, 14(2), 187-209.

First, R., Forjaz, M. \& Manghezi, A. (1998). O mineiro moçambicano: um estudo sobre a exportação de mão de obra de Inhambane. Maputo: Centro de Estudos Africanos, Universidade Eduardo Mondlane.

Frank, A. G. (1967). Capitalism and underdevelopment in Latin America (Vol. 93). New York University Press.

Frankel, Herbert S. (1938). Capital Investment in Africa. Its Course and Effect. London: Oxford University Press.

Frankema, E. (2012). "The origins of formal education in sub-Saharan Africa: was British rule more benign?". European Review of Economic History, 16(4), 335-355.

Frankema, E. (2011). "Colonial taxation and government spending in British Africa, 18801940: Maximizing revenue or minimizing effort?". Explorations in economic history, 48(1), 136-149.

Frankema, E. (2010). "Raising revenue in the British empire, 1870-1940: how 'extractive' were colonial taxes?". Journal of Global History, 5(3), 447-477.

Frankema, E., \& Buelens, F. (2014). Colonial exploitation and economic development: The Belgian Congo and the Netherlands Indies compared. London: Routledge. 
Frankema, E., Green, E. and Hillbom, E. (2016). "Endogenous Processes of Colonial Settlement. The Success and Failure of European Settler Farming in Sub-Saharan Africa”. Revista de Historia Económica, 34(2), pp. 237-265.

Frankema, E., \& Jerven, M. (2014). "Writing history backwards or sideways: towards a consensus on African population, 1850-2010”. The Economic History Review, 67(4), 907-931.

Frankema, E., \& van Waijenburg, M. (2018). “Africa Rising? A Historical Perspective”. African Affairs, https://doi.org/10.1093/afraf/ady022.

Frankema, E., \& van Waijenburg, M. (2014). "Metropolitan blueprints of colonial taxation? lessons from fiscal capacity building in British and French Africa, c. 1880-1940". The Journal of African History, 55(3), 371-400.

Frankema, E., Williamson, J., \& Woltjer, P. (2017). “An Economic Rationale for the West African Scramble?: The Commercial Transition and the Commodity Price Boom of 18351885". Journal of Economic History, 78(2), 1-45.

Gardner, L.A. (2013). "Fiscal policy in the Belgian Congo in comparative perspective'. In: Frankema and Buelens (eds.). Colonial Exploitation and Economic Development: The Belgian Congo and the Netherlands Indies Compared, London: Routledge.

Gardner, L.A. (2012). Taxing colonial Africa: the political economy of British imperialism. Oxford: Oxford University Press.

Gata, A.C.L. (1953-53). Evolução da Prestação do Serviço Militar pelos Indígenas de Moçambique, Lisboa: Escola Superior Colonial.

Gennaioli, N., \& Rainer, I. (2007). “The modern impact of precolonial centralization in Africa”. Journal of Economic Growth, 12(3), 185-234.

Gilley, B. (2017). “The case for colonialism”. Third World Quarterly, 1-17.

Gramsci, A., \& Hoare, Q. (1971). Selections from the prison notebooks (Vol. 294). London: Lawrence and Wishart.

Grier, Robin M. (1999). “Colonial Legacies and Economic Growth”, Public Choice 98 (3-4), 317-335. 
Gwaindepi, A. (2018). State building in the colonial era: public revenue, expenditure and borrowing patterns in the Cape Colony, 1820-1910 (Doctoral dissertation, Stellenbosch: Stellenbosch University).

Hailey, W.M.H.B. (1957). An African survey, revised 1956: a study of problems arising in Africa south of the Sahara. Oxford: Oxford University Press.

Haines, M.R. (2004). "Growing incomes, shrinking people - can economic development be hazardous to your health?: historical evidence for the United States, England, and the Netherlands in the nineteenth century". Social Science History, 28(2), 249-270.

Hammond, R.J. (1966). Portugal and Africa: A Study in Uneconomic Imperialism. Stanford University Press.

Hance, W.A., \& Van Dongen, I. S. (1956). "The port of Lobito and the Benguela railway". Geographical Review, 46(4), 460-487.

Harries, P. (1994). Work, culture, and identity: migrant laborers in Mozambique and South Africa, c. 1860-1910. Pearson Education Ltd.

Havik, P.J. (2013). “Colonial Administration, Public Accounts and Fiscal Extraction: Policies and Revenues in Portuguese Africa (1900-1960)". African Economic History, 41(1), 159-221.

Havik, P.J., Keese, A., \& Santos, M. (2015). Administration and taxation in former Portuguese Africa : 1900-1945. Newcastle upon Tyne: Cambridge Scholars Publishing.

He, W. (2013). Paths toward the modern fiscal state: England, Japan, and China. Cambridge, Massachusetts: Harvard University Press.

Head, J. (1978). Sena Sugar Estates and migrant labour. London: University of London, Institute of Commonwealth Studies.

Herbst, J. (2014). States and power in Africa: Comparative lessons in authority and control. Princeton University Press.

Herbst, Jeffry (2000). States and Power in Africa. Princeton, NJ: Princeton University Press.

Herranz-Loncán, A., \& Fourie, J. (2017). "For the public benefit”? Railways in the British Cape Colony. European Review of Economic History, 1-28. 
Heywood, L.M. (2000). Contested power in Angola, 1840s to the present. Boydell \& Brewer. Hobbes, T., \& Gaskin, J. C. A. (1998[1651]). Leviathan. Oxford: Oxford University Press.

Hobson, J. A. (1965 [1902]). Imperialism: A Study. Ann Arbor: University of Michigan Press.

Hopkins, A. G. (2002). "The history of globalization-and the globalization of history". Globalization in world history, 11-46.

Huillery, E. (2014). "The black man's burden: The cost of colonization of French West Africa." The Journal of Economic History 74 (1):1-38.

Isaacman, A. and Peterson, D. (2003). "Making the Chikunda: military slavery and ethnicity in southern Africa, 1750-1900." The International journal of African historical studies, 36(2).

Isaacman, A.F. (1996). Cotton is the Mother of Poverty: Peasants. Work and Rural Struggle in Colonial Mozambique 1938-1961. Portsmouth, N.H.: Heinemann.

Isaacman, A. (1992). "Coercion, paternalism and the labour process: the Mozambican cotton regime 1938-1961”. Journal of Southern African Studies,18(3), 487-526.

Isaacman, A. F. (1972). Mozambique: the Africanization of a European institution: the Zambesi prazos, 1750-1902. University of Wisconsin Press Madison.

Isaacman, A.F. and Isaacman, B. (1983). Mozambique: from colonialism to revolution, 19001982 (Vol. 3). Boulder, CO: Westview Press.

Isaacman, A., Stephen, M., Adam, Y., Homen, M. J., Macamo, E., \& Pililao, A. (1980). " Cotton Is the Mother of Poverty": Peasant Resistance to Forced Cotton Production in Mozambique, 1938-1961. The International Journal of African Historical Studies, 13(4), 581-615.

Ishemo, S.L. (1989). "Forced Labour, Mussoco (Taxation), Famine and Migration in Lower Zambezia, Mozambique, 1870-1914”. In: Forced labour and Migration: Patterns of Movement within Africa. New York: Hans Zell Publishers.

Jackson, R.H., \& Rosberg, C. G. (1982). "Why Africa's weak states persist: The empirical and the juridical in statehood". World politics, 35(1), 1-24. 
Jamal, V. (1978). "Taxation and inequality in Uganda", 1900-1964. The Journal of Economic History, 38(2), 418-438.

Janeiro, H.P. (2013). "The First Portuguese Republic and the Catholic and Lay Missions in Angola: Finance and Power". Historia y Politica, (29), 161-191.

Jedwab, R., and Storeygard, A. (2017). "Economic and political factors in infrastructure investment: Evidence from railroads and roads in Africa 1960-2015.” IIEP-WP-2017-3

Jedwab, R., and Moradi, A. (2016). "The permanent effects of transportation revolutions in poor countries: evidence from Africa. Review of economics and statistics”, 98(2), 268-284.

Jedwab, R., Kerby, E., \& Moradi, A. (2015). "History, path dependence and development: Evidence from colonial railroads, settlers and cities in Kenya”. The Economic Journal.

Jeeves, A.H. (1985). Migrant labour in South Africa's mining economy: the struggle for the gold mines' labour supply, 1890-1920. McGill-Queen's Press-MQUP.

Jerónimo, M.B. (2013). “The states of Empire”. In: Trindade, L. (ed.). The making of modern Portugal. Newcastle upon Tyne, UK : Cambridge Scholars Publishing.

Jerónimo, M.B., \& Pinto, A. C. (2015). The Ends of European Colonial Empires: Cases and Comparisons. London: Palgrave Macmillan.

Johnson, D. (1990). "Clandestine Migration in South Central Africa", Collected Seminar Papers Institute of Commonwealth Studies, 40, 1-11.

Kagan-Guthrie, Z. (2011). "Repression and Migration: Forced Labour Exile of Mozambicans to São Tomé, 1948-1955”. Journal of Southern African Studies, 37(3), 449-462.

Katzenellenbogen, S.E. (1973). Railways and the copper mines of Katanga. Oxford: Clarendon Press.

Keese, A. (2013). "Searching for the reluctant hands: Obsession, ambivalence and the practice of organising involuntary labour in colonial Cuanza-Sul and Malange districts, Angola, 19261945". The Journal of Imperial and Commonwealth History, 41(2), 238-258. 
Keese, A. (2012). "The Constraints of Late Colonial Reform Policy: Forced Labour Scandals in the Portuguese Congo (Angola) and the Limits of Reform under Authoritarian Colonial Rule, 1955-61”. Portuguese Studies, 28(2), 186-200.

Keese, A. (2007). Living with ambiguity: Integrating an African elite in French and Portuguese Africa, 1930-61. Stuttgart: Steiner.

Keese, A. (2005). "Taxation, Evasion, and Compulsory Measures in Angola", in Philip J. Havik, Alexander Keese, and Maciel M. Santos, Administration and Taxation in Former Portuguese Africa, 1900-1945. Newcastle upon Tyne: Cambridge Scholars Publishing, 98-137.

Killingray, D. (1983). 'The Mutiny of the West African Regiment in the Gold Coast, 1901', The International Journal of African Historical Studies 16(3).

Killingray, D. (1982). The Colonial Army in the Gold Coast: official policy and local response, 1890-1947. (Doctoral dissertation, London: University of London).

Killingray, D. (1979). 'The Idea of a British Imperial African Army', The Journal of African History 20(3).

Klein, H.S. (2010). The Atlantic slave trade. Cambridge: Cambridge University Press.

Klein, M.A. (1998). Slavery and Colonial Rule in French West Africa. Cambridge; New York, NY: Cambridge University Press.

Komlos, J. (1987). "The height and weight of West Point cadets: dietary change in antebellum America". The Journal of Economic History, 47(4), 897-927.

Kyle, S. (1999). "Economic development in Angola and Mozambique". The Africa Notes.

Lains, P. (1998). “An account of the Portuguese African empire, 1885-1975”. Revista de Historia Económica / Journal of Iberian and Latin American Economic History, 16(01), 235263.

Lange, M.K. (2009). Lineages of Despotism and Development. British Colonialism and State Power Chicago: The University of Chicago Press.

La Porta, R., Lopez-de-Silanes F \& Shleifer, A. (2008). “The economic consequences of legal origins". Journal of Economic Literature 46(2), 285-322. 
Lefeuvre, D. (2006). Pour en finir avec la repentance coloniale, Paris: Flammarion.

Lenin, V.I. (1917). Imperialism: the last stage of capitalism (Vol. 4). Communist Party of Great Britain.

Levi, M. (1988). Of rule and revenue. Berkeley: University of California.

Lewis, W.A. (1954). "Economic development with unlimited supplies of labour". The manchester school, 22(2), 139-191.

Lima, A. P. (1971). História dos caminhos de ferro de Moçambique. Lourenço Marques: Administração dos Portos, Caminhos-de-Ferro e Transportes de Moçambique, Vol. I and II.

Lunn, J. (1992). "The political economy of primary railway construction in the Rhodesias, 1890-1911’. The Journal of African History, 33(2), 239-254.

Lloyd, C.B., Kaufman, C. E., \& Hewett, P. (2000). "The spread of primary schooling in subSaharan Africa: implications for fertility change". Population and Development Review, 26(3), 483-515.

Low, D.A. (2009). Fabrication of empire: the British and the Uganda kingdoms, 1890-1902. Cambridge, UK: Cambridge University Press.

Maddison, A. (2010). "Statistics on world population, GDP and per capita GDP, 1-2008 AD'. Historical Statistics, 1-36.

Madeira, A.I. (2005).“Portuguese, French and British discourses on colonial education: Church-State relations, school expansion and missionary competition in Africa, 1890-1930", Paedagogica Historica, 41(1-2).

Madeira Santos, M.E. (2008). "Em Busca dos Sítios do Poder na África Centro Ocidental. Homens e Caminhos, Exércitos e Estradas (1483-1915)". In: von Oppen, A. and B. Heintze (ed.) (2008). Angola on the move: transport routes, communications and history. Frankfurt: Lembeck. pp. 26-40.

Magno, D. (1934). Guerras angolanas. Porto: Companhia Portuguesa Editora, pp. 37-106.

Mamdani, M. (1996). The making of citizen and subject in contemporary Africa. Princeton, N.J: Princeton University Press. 
Martin, I.W., Mehrotra, A. K., \& Prasad, M. (eds.). (2009). The new fiscal sociology: Taxation in comparative and historical perspective. Cambridge University Press.

Marini, R.M. (1972, February). “Brazilian Sub-Imperialism”, Monthly Review, 23(9).

Marseille, J. (1984). Empire colonial et capitalisme français. Histoire d'un divorce, Paris: Albin Michel.

Marx, K. (1853). The East India Company-Its History and Results”. New York Daily Tribune.

Marx, K., \& Engels, F. (1970 [1859]). A Contribution to the Critique of Political Economy, 1.

Mata, M. E. (1993). As finanças públicas portuguesas da Regeneração à primeira Guerra Mundial. Lisbon: Banco de Portugal.

Maxwell, K. (2000). Why Was Brazil Different? The Contexts of Independence. David Rockefeller Center for Latin American Studies, Harvard University.

McCulloch, M. (2017). The Ovimbundu of Angola: West Central Africa. Routledge.

Meagher, K. (2012). "The strength of weak states? Non-state security forces and hybrid governance in Africa". Development and Change, 43(5), 1073-1101.

Messner, J.J., Nate Haken, et al. (2016). Fragile States Index 2016: The Book. Washington DC: The Fund for Peace.

Michalopoulos, S., \& Papaioannou, E. (2013). "Pre-colonial ethnic institutions and contemporary African development". Econometrica, 81(1), 113-152.

Michels, R. (1914). L'imperialismo italiano: studi politico-demografici. Milano: Società editrice libraria,

Mill, J. S. (1844). Essays on Some Unsettled Questions of Political Economy (London, 1844). Essay $V$.

Mitchell, B.R. (2008). International historical statistics: Europe 1750-2005. $6^{\text {th }}$ Edition, New York: Palgrave Macmillan.

Mitchell, B. R. (2007). International historical statistics: Africa, Asia \& Oceania, 1750-2005. New York: Palgrave Macmillan. 
Mkandawire, T. (2010). "On tax efforts and colonial heritage in Africa". The Journal of Development Studies, 46(10), 1647-1669.

Moreno, M. (1937). “Aspectos da defesa militar de Angola”. Separata da Revista Militar. Lisboa, 1-15.

Mouffe, C. (Ed.). (2014). Gramsci and Marxist Theory. Routledge.

Moyse-Bartlett, L.C.H. (2012). The King's African Rifles (Vol. 1 and 2). Andrews UK Limited.

Musgrave, R.A. (1992). "Schumpeter's crisis of the tax state: An essay in fiscal sociology". Journal of Evolutionary Economics, 2(2), 89-113.

Neil-Tomlinson, B. and Vail, L. (1977). "Discussion: The Mozambique Company”, Journal of African History, 18:2, 283-286.

Newitt, M.D. (1995). A history of Mozambique. Bloomington: Indiana University Press.

Newitt, M.D. (1981). Portugal in Africa: The last hundred years. Longman Publishing Group. Newitt, M.D. (1969). "The Portuguese on the Zambezi: An historical interpretation of the Prazo system." Journal of African History, 10, 67-85.

Newitt, M., \& Tornimbeni, C. (2008). "Transnational Networks and Internal Divisions in Central Mozambique". Cahiers d'études africaines, (4), 707-740.

North, D.C., Summerhill, W. and Weingast, B.R. (2000). "Order, Disorder and Economic Change", in B.B. de Mesquita and H.L. Root (eds.), Governing for Prosperity, New York: Yale University Press, pp. 17-58.

O' Brien, P.K. (1988). "The costs and benefits of British imperialism 1846-1914". Past \& Present, 120(1), 163-200.

O' Laughlin, B. (2002). "Proletarianisation, agency and changing rural livelihoods: forced labour and resistance in colonial Mozambique". Journal of Southern African Studies, 28(3), $511-530$.

O' Laughlin, B. (2000). "Class and the customary: the ambiguous legacy of the indigenato in Mozambique". African Affairs, 99(394), 5-42. 
Olsson, J. (2016). “Agency in new institutionalism". In Subversion in Institutional Change and Stability. London: Palgrave Macmillan, 11-37.

Ottaway, M., Herbst, J.I., \& Mills, G. (2004). Africa's big states: toward a new realism. Washington, DC: Carnegie Endowment for International Peace.

Pakenham, T. (1992). The Scramble for Africa. The White Man's Conquest of the Dark Continent from 1876-1912. New York: Avon Books.

Parsons, T. (1999). The African rank-and-file: social implications of colonial military service in the King's African Rifles, 1902-1964. Oxford: James Currey.

Paton, B. (1994). Labour export policy in the development of Southern Africa. Springer.

Pélissier, R. (1987). História de Moçambique: formação e oposição (1854-1918). Editorial Estampa.

Penvenne, J. (1995). African workers and colonial racism: Mozambican strategies and struggles in Lourenço Marques, 1877-1962. Portsmouth N.H.: Heinemann.

Penvenne, J. (1979). Attitudes towards Work and Race in Mozambique: Lourenço Marques, 1900-1974. Boston University, African Studies Center: Working Papers.

Penvenne, J.M., Elkins, C., \& Pedersen, S. (2005). "Settling against the Tide: The layered contradictions of twentieth century Portuguese settlement in Mozambique”. Settler Colonialism in the Twentieth Century. New York: Routledge, 79-94.

Pereira, H.S. (2017). "Especulação, Tecnodiplomacia e os caminhos-de-ferro coloniais entre 1857 e 1881”. História: revista da Faculdade de Letras da Universidade do Porto, 7.

Phimister, I.R. (1981). “Towards a History of Zimbabwe's Rhodesia Railways"”. Zimbabwean History, XII, 71.

Phimister, I. R. (1974). "Rhodes, Rhodesia and the Rand". Journal of Southern African Studies, 1(1), 74-90.

Piketty, T. (2014). Capital in the twenty-first century. Cambridge Massachusetts: The Belknap Press of Harvard University Press. 
Pimenta, F.T. (2016). "White settler politics and Euro-African nationalism in Angola, 19451975" in: Cavanagh, E., \& Veracini, L. (eds.) The Routledge Handbook of the History of Settler Colonialism. Taylor \& Francis.

Pinto, A.C., \& Teixeira, N.S. (2004). From Atlantic past to European destiny: Portugal. Abingdon, UK: Taylor \& Francis, 112-130.

Pinto Coelho, M.T. (1990). "'Pérfida Albion' and 'Little Portugal': The Role of the Press in British and Portuguese National Perceptions of the 1890 Ultimatum.” Portuguese Studies, 6.

Pirie, G. (1993). "Railways and labour migration to the Rand mines: constraints and significance". Journal of Southern African Studies, 19(4), 713-730.

Pitcher, M.A. (1991). "Sowing the seeds of failure: early Portuguese cotton cultivation in Angola and Mozambique, 1820-1926”. Journal of Southern African Studies, 17(1), 43-70.

Pomeranz, K. (2000). The great divergence: China, Europe, and the making of the modern world economy. Princeton, NJ: Princeton University Press.

Poulantzas, N. (1987). Political power and social classes. London: Verso.

Ribeiro da Silva, F. (2016). "Political Changes and Shifts in Labour Relations in Mozambique, 1820s-1920s”. International Review of Social History, 61(Special Issue), 1-21.

Rodney, W. (1972). How Europe underdeveloped Africa. London: Bogle-L'Ouverture Publications.

Roque, R. (2003). “The razor's edge: Portuguese imperial vulnerability in colonial Moxico, Angola”. The International journal of African historical studies, 36(1), 105-124.

Ross, E.A. (1925). Report on employment of native labor in Portuguese Africa. Abbott Press.

Rotberg, R.I. (2004). State failure and state weakness in a time of terror. Brookings Institution Press.

Roy T. (2018, forthcoming). 'Why was British India (1858-1947) a Limited State?', in Ewout Frankema and Anne Booth (eds.), Fiscal Capacity and the Colonial State in Asia and Africa, c. 1850-1960, Cambridge UK: Cambridge University. 
Rustow, D.A. (1970). “Transitions to democracy: Toward a dynamic model." Comparative politics, 2(3), 337-363.

Santos, M. (2015). "Peasant taxation and the funding of the colonial state in the Portuguese colonies (1900-1939). In: Havik, P. J., Keese, A., \& Santos, M. (2015). Administration and taxation in former Portuguese Africa: 1900-1945. Newcastle upon Tyne, UK: Cambridge Scholars Publishing.

Santos, M.M. (2012). “O imposto camponês no Norte de Moçambique (1929-1939): um cultivo forçado, factor de crescimento?". Atas do Congresso Internacional Saber Tropical em Moçambique: História, Memória e Ciência. Lisboa: IICT - Jardim Botânico Tropical.

Santos, M.M. (2007a). "Imposto e algodao: o caso de Moçambique (1926-1945)”. In: Centro de Estudos Africanos da Universidade do Porto (Org.). Trabalho Forçado Africano. Articulações com o poder político. Colecção Estudos Africanos. Porto: Campo das Letras Editores, S.A.

Santos, M.M. (2007b). “An obsessive idea-Native taxation in northern Mozambique (19261945)". Working Paper / CEAUP.

Schumpeter, J.A. (1918). Die Krise des Steuerstaats. Leuschner \& Lubensky.

Smith, A.K. (1974). "António Salazar and the reversal of Portuguese colonial policy." Journal of African History 15(4), 653-667.

Sokoloff, K.L., \& Engerman, S.L. (2000). "History lessons: Institutions, factors endowments, and paths of development in the new world". The Journal of Economic Perspectives, 14(3), 217-232.

Solli, A., \& Leysens, A. (2011). "(Re)Conceptualizing the Political Economy of the African State Form: The Strong/Weak State Contradiction in Angola”. Politikon, 38, 2, 295-313.

Stotsky, J.G., \& WoldeMariam, A. (1997). "Tax effort in sub-Saharan Africa." IMF Working Paper, 1-57.

Telo, A.J. (1994a). Economia e império no Portugal contemporâneo. Edições Cosmos. 
Telo, A.J. (1994b). “As guerras de África e a mudança nos apoios internacionais de Portugal”. Revista De História Das Ideias, 16, 347-369.

Tilly, C. (1990). Capital, coercion and European states. Cambridge, MA: Basil Blackwell.

Tilly, C., McAdam, D., \& Tarrow, S. (2001). Dynamics of contention. Cambridge: Cambridge University Press.

Togliatti, P., M. Ciliberto, and G. Vacca (20140. La politica nel pensiero e nell'azione: scritti e discorsi : 1917-1964. Milano: Bompiani.

Tornimbeni, C. (2012). “The Informalization of Formal Portuguese Controls on People's Movements and Identity in the Colony of Mozambique: The Heritage of Portuguese Colonialism in Current Local African Politics”. Portuguese Studies, 28(2), 216-229.

Tornimbeni, C. (2005). "The State, Labour Migration and the Transnational Discourse-A Historical Perspective from Mozambique". Wiener Zeitschrift für kritische Afrikastudien, 5(8), $307-28$.

Tracey, H. (1970). Chopi musicians: Their music, poetry, and instruments. London: Oxford University Press.

Tunçer, A.C. (2015). Sovereign Debt and International Financial Control: The Middle East and the Balkans, 1870-1914. London: Palgrave Macmillan.

Udelsmann Rodrigues, C., \& Tavares, A.P. (2012). “Angola's planned and unplanned urban growth: diamond mining towns in the Lunda Provinces". Journal of Contemporary African Studies, 30(4), 687-703.

Ukpabi, S.C. (1987). The Origins of the Nigerian Army:(a History of the West African Frontier Force, 1897-1914). Gaskiya Corporation.

Vail, L. (1975). “The making of an imperial slum: Nyasaland and its railways, 1895-1935”. The Journal of African History, 16(1), 89-112.

Vail, L., \& White, L. (1981). Capitalism and colonialism in Mozambique: A study of Quelimane District. Minneapolis: University of Minnesota Press. 
Vail, L., \& White, L. (1978). “'Tawani, Machambero!': Forced Cotton and Rice Growing on the Zambezi”. The Journal of African History, 19(02), 239-263.

Valério, N. (2002). “The Escudo Zone - a Failed Attempt at Colonial Monetary Union (196271)". In the 13th International Economic History Congress. Buenos Aires.

Valério N. (2001). Estatísticas históricas portuguesas: Portuguese historical statistics. Lisboa: Instituto Nacional de Estatística.

Valério, N., \& Tjipilica, P. (2008). "Economic activity in the Portuguese Colonial Empire: a factor analysis approach". Economies et sociétés, 42(9), 1765-1807.

Van den Berg, J. (1987). "A peasant form of production: wage-dependent agriculture in southern Mozambique". Canadian Journal of African Studies / La Revue canadienne des études africaines, 21(3), 375-389.

Van Waijenburg, M. (2018). "Financing the African Colonial State: The Revenue Imperative and Forced Labor". The Journal of Economic History, 78(1), 40-80.

Varanda, J., \& Cleveland, T. (2014). "(Un) healthy Relationships: African Labourers, Profits and Health Services in Angola's Colonial-Era Diamond Mines, 1917-75”. Medical history, $58(01), 87-105$.

Varian, H.F. (1953). Some African Milestones. G. Ronald.

Venter, A. (2013). Portugal's Guerrilla Wars in Africa: Lisbon's Three Wars in Angola, Mozambique and Portuguese Guinea 1961-74. Solihull: Helion.

Von Trotha, T. (2009). The "Andersen Principle": On the Difficulty of Truly Moving Beyond State-Centrism. In: Martina Fischer and Beatrix Schmelzle (eds.). Building Peace in the Absence of States: Challenging the Discourse on State Failure. Berghof Handbook Dialogue Series, 8, 37-46.

Wallerstein, I.M. (1986). Africa and the modern world. Africa World Press.

Wesseling, H.L. (1996). Divide and rule: The partition of Africa, 1880-1914 (No. 275-95133). Praeger Publishers. 
Wheeler, D.L. (1972). “Origins of African Nationalism in Angola: assimilado protest writings, 1859-1929”. in: Chilcote, R. H., Protest and resistance in Angola and Brazil: comparative studies. Berkeley and Los Angeles CA: University of California Press.

Wheeler, D.L. (1969). "The Portuguese Army in Angola”. The Journal of Modern African Studies, 7(03), 425-439.

White, L. (1993). Bridging the Zambesi: A colonial folly. Houndmills: Macmillan.

Wilson, F. (1976). "International migration in southern Africa". International Migration Review, 451-488.

Woodward, S.L. (2017). The Ideology of Failed States. Cambridge University Press.

Young, C. (2012). The postcolonial state in Africa: Fifty years of independence, 1960-2010. University of Wisconsin Pres.

Young, C. (1994). The African colonial state in comparative perspective. Yale University Press.

Young, C. (1988). The African colonial state and its political legacy. The Precarious Balance: state and society in Africa. Boulder Co: Westview Press, 25-66.

Zamparoni, V.D. (2000). Frugalidade, moralidade e respeito: A política do assimilacionismo em Moçambique, c. 1890-1930. In X Congresso Internacional da Associação Latino-Americana de Estudos Afro-asiáticos.

\section{Internet sources}

International Labour Organization (1930). Forced Labour Convention (No. 29).

http://www.ilo.ch/dyn/normlex/en/f?p=NORMLEXPUB:11300:0::NO:11300:P11300 INSTR UMENT ID:312174:NO. Retrieved $15^{\text {th }}$ August, 2018

Mike's Railway History. Across Africa by Rail, http://mikes.railhistory.railfan.net/r011.html 
Organisation for Economic Co-operation and Development - OECD (2016). States of Fragility 2016: Understanding Violence. Paris: OECD Publishing, https://doi.org/10.1787/9789264267213-en. Retrieved 15 th August, 2018

Rede Angola (2014). Há guerra em Moçambique, http://www.redeangola.info/especiais/haguerra-em-mocambique/. Retrieved $15^{\text {th }}$ August, 2018

Silva, E.R.S. (2008). Companhia do Caminho de Ferro de Benguela: Uma história sucinta da sua formação e desenvolvimento. Lisboa: https://sites.google.com/site/cfbumahistoriasucinta/. Retrieved $15^{\text {th }}$ August, 2018

The Delagoa Bay Review (2012, 13 March). A História da Ponte Dona Ana.

https://delagoabayword.wordpress.com/category/arquitectura-mocambique/historia-da-pontedona-ana/. Retrieved $15^{\text {th }}$ August, 2018 
Kleoniki Alexopoulou Giannakitsa

Wageningen School of Social Sciences (WASS)

Completed Training and Supervision Plan

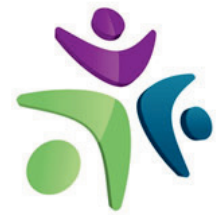

Wageningen School

of Social Sciences

\begin{tabular}{|c|c|c|c|}
\hline Name of the learning activity & Department/Institute & Year & ECTS* \\
\hline \multicolumn{4}{|l|}{ A) Project related competences } \\
\hline Seminar 'My project in a nutshell seminar' & N.W. Posthumus Institute & 2013 & 2 \\
\hline Work in progress seminar & N.W. Posthumus Institute & 2013 & 6 \\
\hline Research design course & $\begin{array}{l}\text { N.W. Posthumus Institute, Goethe } \\
\text { University, Frankfurt }\end{array}$ & 2014 & 8 \\
\hline Individual assesment & N.W. Posthumus Institute & 2014 & 1 \\
\hline $\begin{array}{l}\text { Organising a masterclass with Dr Leigh } \\
\text { Gardner }\end{array}$ & RHI group, WUR & 2015 & 1 \\
\hline Discussant at PhD conference & $\begin{array}{l}\text { N.W.Posthumus Institute, University } \\
\text { of Brussels }\end{array}$ & 2015 & 2 \\
\hline \multicolumn{4}{|l|}{ B) General research related competences } \\
\hline Research Proposal & WASS & 2013 & 4 \\
\hline $\begin{array}{l}\text { "Fiscal regimes: shaping state and social } \\
\text { transformations in colonial Mozambique and } \\
\text { Angola (1890s-1970s) }\end{array}$ & $\begin{array}{l}\text { 9th Annual Meeting of African } \\
\text { Economic History Network, London } \\
\text { School of Economics, UK }\end{array}$ & 2014 & 1 \\
\hline $\begin{array}{l}\text { 'Obey or pay: Taxation, migration and forced } \\
\text { labour in Mozambique in the first half of the } \\
\text { 20th century' }\end{array}$ & $\begin{array}{l}\text { Workshop "Colonialism, Growth and } \\
\text { Development in the Southern } \\
\text { Hemisphere, 1800-2000", Lund } \\
\text { University, Sweden }\end{array}$ & 2015 & 1 \\
\hline $\begin{array}{l}\text { 'Metropolitan vision under question: Fiscal } \\
\text { policies and practices in Portuguese Africa } \\
\text { (1850s-1970s)' XVII World Economic History } \\
\text { Congress }\end{array}$ & $\begin{array}{l}\text { XVII World Economic History } \\
\text { Congress , Kyoto, Japan }\end{array}$ & 2015 & 1 \\
\hline $\begin{array}{l}\text { 'Colonial state formation without integration: } \\
\text { Tax and labour regimes in Portuguese } \\
\text { Mozambique (1890s-1970s)' }\end{array}$ & $\begin{array}{l}40^{\text {th }} \text { Meeting of the Social Science } \\
\text { History Association, Baltimore MD, } \\
\text { US }\end{array}$ & 2015 & 1 \\
\hline $\begin{array}{l}\text { 'Do Economies of Scale Matter? Effective } \\
\text { Occupation and Military Spending in } \\
\text { Portuguese, French and British Africa in the } \\
\text { Early Colonial Period (1890s-1940s)' }\end{array}$ & $\begin{array}{l}\text { European Social Science History } \\
\text { Conference, Valencia, Spain }\end{array}$ & 2016 & 1 \\
\hline $\begin{array}{l}\text { 'Regressive redistribution and infrastructure } \\
\text { development in Portuguese Mozambique } \\
\text { (1890s-1970s)' }\end{array}$ & $\begin{array}{l}\text { Economic History Society } \\
\text { Conference, Royal Holloway } \\
\text { University of London, UK }\end{array}$ & 2017 & 1 \\
\hline
\end{tabular}




\section{C) Career related competences}

WASS Introduction course

WASS

2013

1

Scientific Writing course

WGS

$2014 \quad 1.8$

Organising the monthly seminar

RHI group, WUR

$2016 \quad 1$

Tutoring Theories on Politics and Governance

IDS, WUR

2016

course

Research visit at foreign research institute

Bologna University, Italy

2017

Co-organising a panel at Fifth European

Congress on World and Global History

Central European University,

Budapest, Hungary

2017

6

(ENIUGH)

Total

*One credit according to ECTS is on average equivalent to 28 hours of study load 


\section{FUNDING}

This research was funded by a Netherlands Organization for Scientific Research (NWO) for the project "Is poverty Destiny? Exploring Long Term Changes in African Living Standards in Global Perspective" (NWO VIDI Grant no. 016.124.307).

\section{COVER IMAGE}

Cartão Postal. Companhia de Diamantes de Angola, Grupo de Andrada - Mulheres de trabalhadores contratados, regressando de uma distribuição de mandioca, feita pela Secção de Propaganda e Assistência à Mão-de-Obra indígena (SPAMOI). Sem data, princípio século XX.

In English: Photographic Postcard. Company of Diamonds of Angola, Group of Andrada Wives of forced contract workers, returning from cassava distribution, done by the Section of Propaganda and Assistance to Indigenous Labour (SPAMOI). Undated, early $20^{\text {th }}$ century.

Sources: Filipa Lowndes Vicente's Collection. Already published in the book O Império da Visão: fotografia no contexto colonial português (1860-1960), ed. Filipa Lowndes Vicente (Lisboa: Edições 70, 2014), p. 13.

Conhecimento e Visão, Fotografia no Arquivo e no Museu Colonial Português 1850-1950. Instituto de Ciências Sociais da Universidade de Lisboa (ICS).

Cover design: Kleoniki Alexopoulou and Dennis Hendriks

Printed: ProefschriftMaken.nl 
